
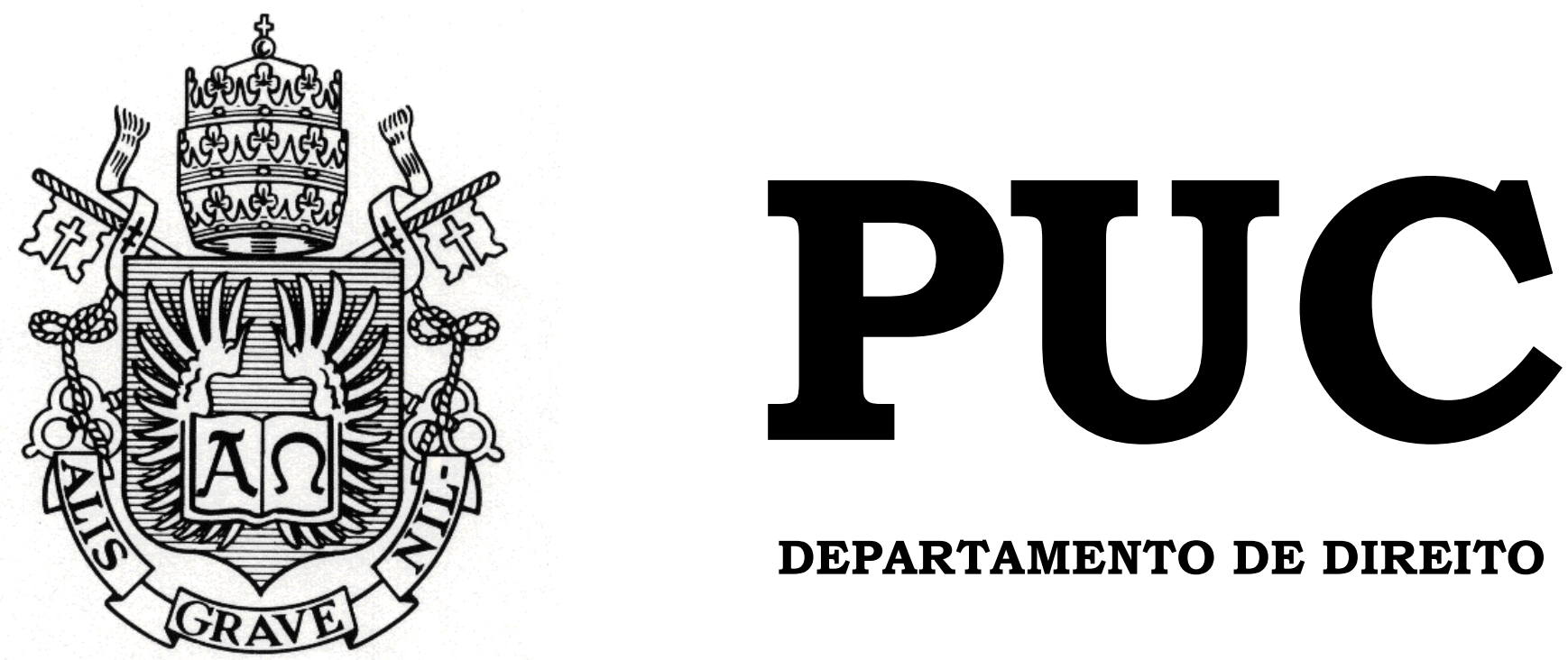

DEPARTAMENTO DE DIREITO

\title{
Uma Análise Funcional da Transferência de Controle na Sociedade Anônima
}

por

Caetano Penna Franco Altafin Rodrigues da Cunha

ORIENTADOR: Marcelo Fernandez Trindade

2008.2

PONTIFÍCIA UNIVERSIDADE CATÓLICA DO RIO DE JANEIRO

RUA MARQUÊS DE SÃO VICENTE, 225 - CEP 22453-900

$$
\text { RIO DE JANEIRO - BRASIL }
$$




\title{
Uma Análise Funcional da Transferência de Controle na Sociedade Anônima
}

\author{
por \\ Caetano Penna Franco Altafin Rodrigues da Cunha
}

Monografia apresentada ao Departamento de Direito da Pontificia Universidade Católica do Rio de Janeiro (PUC-Rio) para a obtenção do Título de Bacharel em Direito.

Orientador: $\quad$ Marcelo Fernandez Trindade 
Aos meus pais, minha gratidão;

À minha Dê, meu amor;

A meu mano, meu sorriso. 


\section{Agradecimentos}

Este trabalho é fruto da dedicação daqueles que, por diversas maneiras, auxiliaram na sua realização. A Marcelo Fernandez Trindade, agradeço pelos anos de orientação e aprendizado na Pontifícia Universidade Católica - Rio. À Aline de Menezes Santos, pela bibliografia e competência revestida na simpatia de cada dia. A Marcos Barbosa Pinto, Bruno Robert e Ricardo Canguçu Castorri, pela paciência e ensinamentos. Ao Professor Jess Bull, do Departamento de Economia da Universidade da Califórnia - San Diego, pelos valiosos debates. A Celso de Albuquerque Mello, in memoriam. A Francisco Mauro Dias, Luiz Emygdio da Rosa Júnior e Regina Lisboa Soares, pelo exemplo de amor ao direito. Aos professores Adriano Pilatti, Francisco Guimarães e aos colegas do PET-Jur, Daniel Lévy, Julia Alexim, Bernardo Bianchi, Jorge Chaloub, Janaína Matilda, Priscila de Santana, Ana Carolina Quintanilha e Francisco Carvalheira; pelos anos de convivência e dedicação à nossa Pontifícia. Aos amigos e colegas Pedro Massena Gomes, Rodrigo Cavalcanti Moreira, pelos debates travados ao longo destes cinco anos de graduação. Aos meus pais por eleição, Maggy Cordeiro Azevedo, Ubiratan Cerqueira Azevedo e Lygia Maria Jobim, meu carinho. Aos meus pais Luiz Fernando e Elym, todo a minha gratidão pela dedicação que me trouxe até aqui. À minha irmã Mariana, minha afeição. Aos amigos Alexandre, Diogo, Clóvis, Adriano, João, Pedro, Gustavo, e Dani, meus sorrisos. À minha vida e inspiração, meu sol, Denise Dutra Foligno, todo meu amor e cumplicidade e a meu irmão Rafael Cordeiro Azevedo, meu exemplo nesta eterna saudade. Gratíssimo. 


\section{Resumo}

Este trabalho concentra-se na observação das relações decorrentes da transferência de controle na sociedade anônima, sob uma perspectiva analíticofuncional. Propõe-se sua divisão em cinco etapas principais. Primeiro, são discutidas as acepções de 'poder' e de 'controle', de modo a se delinear uma concepção comum a ambos os conceitos, compreendidos na expressão 'poder de controle', que seja adequada ao estudo de sua transferência na sociedade anônima. Em seguida, são apresentados os fundamentos que justificam a adoção da análise funcional proposta à leitura das relações societárias ou, aqui especificamente, para que, através do direito, se permita a regulação eficiente da transferência de controle na sociedade anônima. Apresentado o instrumental teórico típico à análise principal-agente adotada, passa-se à discussão de três dos principais elementos que compreendem o estudo da transferência de controle: a sua desejabilidade econômico-social, a natureza do prêmio correspondente ao controle e a legitimidade econômico-funcional das estratégias de defesa à tomada de poder de controle. Na quarta etapa deste estudo, são analisadas em espécie as operações compreendidas na categoria 'transações de controle' proposta de acordo com a análise funcional das relações societárias: a cessão de controle acionário e a oferta pública à sua aquisição. Em sua quinta e última parte, discute-se o entendimento consolidado da Comissão de Valores Mobiliários - CVM, sobre a configuração da alienação do controle acionário no ordenamento jurídico brasileiro. Por fim, conclui-se se é a diversidade de pressupostos adotados por cada modelo analisado e em acréscimo à influência exercida pelos agentes econômicos na regulação da transferência de controle que justificam a existência de sistemas jurídicos inteiramente distintos a respeito de um mesmo tema.

Palavras-chave: sociedade anônima, transferência de controle, oferta pública de aquisição, OPA, poison pill, CVM, mercado de capitais. 


\section{Sumário}

Introdução 10

1 A realidade do poder na sociedade anônima. .20

1.1 O poder soberano na sociedade anônima: uma proposta de leitura 'constitucional' do poder de controle. .20

1.2 McCulloch v. Maryland (1819): a aplicação da doutrina dos poderes implícitos no direito constitucional norte-americano vis-à-vis as teorias do 'business judgment rule' e dos 'implied corporate powers'.26 1.3 O 'Court-packing plan' rooseveltiano (1937) e as restrições na alteração da estrutura da diretoria na sociedade anônima em $M M$. Companies Inc. v. Liquid Áudio, Inc. (2003). .31

2 O controle: conceito, localização e classificação no direito societário.38

2.1 O controle e suas acepções no direito societário. .38

2.2 A localização do controle no direito societário contemporâneo.

2.3 Berle e Means: o controle interno e sua classificação. 45

2.4 Bayne vis-à-vis Comparato: o fenômeno do controle externo na sociedade anônima.

3 Uma proposta de releitura funcional do direito societário: tutela e objetivos. 60 
3.1 O desenvolvimento do direito societário contemporâneo e a tutela da informação no mercado de capitais: pressupostos. 60

3.2 Easterbrook e Fischel: a teoria do contrato plurilateral ascarelliana e os fundamentos e limites da regulação

3.3 A ratio do direito societário à luz do modelo de regras hartiano: escopo, objetivos e o dever de fidúcia na sociedade anônima .80

3.4 A abordagem principal-agente: estratégias regulatórias e de governança na sociedade anônima. .91

4 Uma análise funcional da transferência de controle na sociedade anônima: fundamentos .107

4.1 As 'transações de controle' na sociedade anônima segundo Davies e Hopt: escopo .107

4.2 A desejabilidade econômico-social da transferência do controle acionário na sociedade anônima. 113

4.3 O 'premium bribe' e os direitos de saída na transferência do controle acionário

4.4 A análise funcional-comparativa dos instrumentos de defesa a uma oferta pública hostil de tomada de poder de controle: caracterização e fundamentos.

5 A transferência de controle na sociedade anônima 147

5.1 A cessão do controle acionário: natureza, características e regulação 
5.2 A oferta pública de aquisição do controle: natureza, características e regulação...........................................................155

5.3 A configuração da alienação do controle acionário no direito brasileiro - tratamento legal e o entendimento da Comissão de Valores

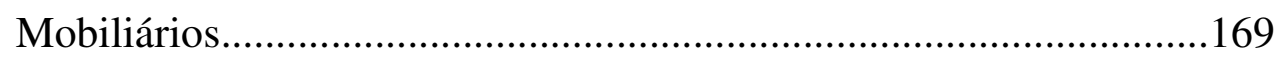

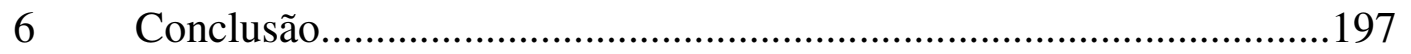

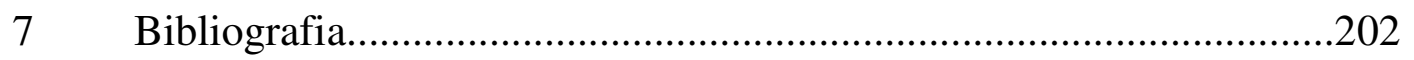


"Power is a means to an end. The end is everything, without exception, which the human being calls pleasure, and the removal of pain. The grand instrument for attaining what a man likes is the actions of other men. Power, in its most appropriate signification, therefore, means security for the conformity between the will of one man and the acts of other men. This, we presume, is not a proposition which will be disputed. The master has power over his servant, because when he wills him to do so and so, in other words, expresses a desire that he would do so and so, he possesses a kind of security that the actions of the man will correspond to his desire" $^{\prime 1}$ (Mill, 1820).

\footnotetext{
1 "MILL, James. An Essay on Government. § 42.

Disponível em <http://www.mdx.ac.uk/WWW/STUDY/xMilgov.htm>. Acesso em 25 jun. 2008. "O poder é um meio para um fim. O fim é tudo, sem exceção, que a humanidade trata como forma de se gerar prazer e de se evitar a dor. O maior instrumento para o alcance daquilo que o homem deseja é a ação de outros homens. Poder, no sentido que lhe é mais próprio, significa a segurança em se alcançar a conformidade entre o desejo de um homem e a atitude de outros. Isso, nós presumimos, não é uma proposição que deva ser questionada. $\mathrm{O}$ senhor possui poder sobre o seu servo, porque quando aquele deseja que esse faça algo, ou expressa um desejo sobre a atitude que deve adotar, o senhor possui a segurança de que as ações de seu servo corresponderão ao seu desejo manifestado" Tradução livre.
} 


\section{Introdução}

"The phenomenon of 'control' is perhaps the most important single fact in the American Corporate System. As the corporation increasingly is recognized as an institution of primary significance (...) the importance of control grows in law as it has grown in economic and social fact. Corporation law has never surrounded this phenomenon. Rules have been developed with respect to isolated aspects of it; but the rules derive chiefly from a time when corporations were still truly private and relatively small (...)", (Berle, 1958).

O maior destaque atribuído ao estudo do poder de controle, até o reconhecimento de sua imprescindibilidade para a compreensão do fenômeno da sociedade anônima, decorre de peculiaridades que transcendem a estrita esfera daqueles que o exercem. Compreendida a relevância, tal qual a centralidade de seu exercício, passa-se à sua regulação, em busca da realização das finalidades últimas a que se pode prescrever ao direito. Dentre tantos objetivos possíveis de ser realizados pelo regulador, destaca-se o de propiciar, através da estruturação da sociedade anônima, as condições necessárias para o incremento do bem-estar social decorrente do exercício da companhia.

Essa expansão dos meios de capitalização das atividades produtivas teve, como precedente, a dissociação das atividades desenvolvidas de seus diretos participantes. A delimitação da pessoa jurídica em seus deveres e obrigações mostrou-se condição elementar ao sucesso das sociedades empresárias. Foi através da limitação da responsabilidade dos agentes econômicos, mediante a personificação das atividades desenvolvidas sob e pela sociedade contratada, que se tornou possível dar segurança aos agentes

\footnotetext{
${ }^{2}$ BERLE, Adolf A. Control in Corporate Law. Columbia: Columbia Law Review, 1958. p. 1.212. Ap. BAYNE, David Cowan. The Philosophy of Corporate Control: a Treatise on the Law of Fiduciary Duty. $1^{\text {st }}$ Ed. Chicago: Loyola University Press, 1986. p. xiii. "O fenômeno do "controle" é talvez o mais importante fato no direito societário norte-americano. Enquanto a companhia é progressivamente reconhecida como instituição de maior importância (...) a importância do controle cresce no direito, assim como o fez como fato econômico e social. O direito societário nunca se aproximou desse fenômeno. Regras foram desenvolvidas com respeito a aspectos isolados do controle; mas as regras atuais derivam principalmente de um período em que as companhias eram de propriedade restrita a poucos sócios e relativamente pequenas (...)” Tradução livre.
} 
econômicos para a realização de determinadas empresas. Nessa função, dentre as figuras jurídicas que historicamente obtiveram maior sucesso, evidencia-se a sociedade anônima ${ }^{3}$.

Como matriz decisória da companhia, percebe-se a potência do poder de controle. Intangível de propriedade tão controversa, cuja transferibilidade e regulação propiciam, ainda, mais intensos e calorosos debates. De tudo isso resulta a direta correlação entre a riqueza e a ainda grave obscuridade que muitas das dimensões do exercício do poder de controle apresentam. Percebese a importância do estudo do exercício tanto da sociedade anônima, estrutura propícia e concebida para o desenvolvimento da atividade econômica organizada, quanto do poder de controle, como real origem de seu domínio.

Do conceito de sociedade depreende-se uma segunda característica que, tal como sua individualização, lhe é elementar ${ }^{4}$. A sociedade resulta da junção de esforços em torno de uma determinada atividade econômica ${ }^{5}$. A própria etimologia do verbete 'companhia’ remete a essa mesma explicação. Derivada da aglutinação dos termos 'cum' e 'panis' (ou 'aqueles que comem do mesmo

\footnotetext{
${ }^{3}$ Kenneth Clarkson destaca que foi a excepcionalidade na adoção de medidas de responsabilização direta dos sócios, conseqüente da existência de pessoa jurídica dotada de patrimônio próprio que lhes é distinta, que possibilitou o desenvolvimento das sociedades empresárias e o sucesso das atividades por elas desenvolvidas: "In certain circumstances of fraud, undercapitalization, or careless observance of corporate formalities, a court will pierce the corporate veil (disregard the corporate entity) and hold the shareholders individually liable. These situations are the exception, not the rule, however". CLARKSON, Kenneth W.. et. al.. West's Business Law: Text and Cases. $10^{\text {th }}$ Ed. Mason: Thomson West Mason, 2006. p. 799 "Em certas circunstâncias de fraude, subcapitalização ou negligência na observação das formalidades da sociedade anônima, a Corte "abrirá o véu da companhia" (desconsiderará a sua personalidade jurídica) e responsabilizará individualmente os sócios. Essas situações são, no entanto, a exceção e não a regra". Tradução livre.

${ }^{4}$ FILHO, Alfredo Lamy; PEDREIRA, José Luiz Bulhões. A Lei das S.A.. Vol. I, $3^{\text {a }}$ Ed.. Rio de Janeiro: Editora Renovar, 1997. p. 56.

5 A teoria econômica demonstra como a organização da produção realizada através da comunhão de diversos agentes em torno de um mesmo empreendimento, possibilita a expansão do excedente do produtor, calculável através da subtração do valor obtido com a venda de uma determinada unidade, de seu respectivo custo de produção. KRUGMAN, Paul. Economia Internacional: teoria e política. $5^{\text {a }}$ Ed.. São Paulo: Makron Books, 2004. p. 44.
} 
pão" $)^{6}$, a expressão denota a comunhão de esforços realizada pelos agentes econômicos, a fim de se alcançar uma finalidade que lhes seja comum ${ }^{7}$.

Dessa forma, nota-se o papel fundamental exercido pelo mercado de capitais para o crescimento econômico na sociedade contemporânea. Possibilitar aos agentes econômicos a captação de recursos para o desenvolvimento de atividades que assim demandassem conduziu ao aumento das escalas produtivas e à conseqüente elevação do bem-estar social gerado pelas trocas comerciais ${ }^{8}$. É diante desta perspectiva econômico-estrutural do funcionamento da sociedade anônima que se busca, através da melhor compreensão dos fundamentos e da realidade em si do poder de controle, regulamentá-lo em seu exercício ${ }^{9}$.

Com efeito, a relevância do estudo do poder não se restringe às ciências jurídicas. Conforme destaca Adolf Berle em seu ensaio sobre o tema, tamanho o caráter totalizador do poder em sociedade, que se observa o seu extravaso nas tantas dimensões da existência humana:

\footnotetext{
${ }^{6}$ FILHO, Alfredo Lamy; PEDREIRA, José Luiz Bulhões. Op. cit., p. 27.

${ }^{7}$ A essa regra, excepcionam-se as sociedades caracterizáveis como unipessoais, como, por exemplo, a sole proprietorship do direito norte-americano e a subsidiária integral prevista no ordenamento brasileiro entre os arts. 251 e 253, da Lei $n^{\circ}$ 6.404, de 5 de dezembro de 1976. CLARKSON, Kenneth W.. et. al.. Op. cit., p. 718 e ss.

${ }^{8}$ Assim explicam John Micklethwait e Adrian Wooldridge: "Lowe and Gladstone ushered in an organization that has been uniquely effective in rendering human effort productive. The idea that the company itself was an enabling technology is something that liberal thinkers once understood instinctively. The limited liability corporation is the greatest single discovery of modern times", proclaimed Nicholas Murray Butler (...)". MICKETHWAIT, John; WOOLDRIDGE, Adrian. The Company: A short history of a revolutionary idea. New York: The Modern Library, 2005. p. xxi. "Lowe e Gladstone conceberam uma organização que tem sido unicamente eficiente em tornar o esforço humano produtivo. A idéia de que a companhia é em si uma tecnologia capacitadora é algo que os pensadores liberais entenderam instintivamente. A sociedade de responsabilidade limitada é a maior descoberta dos tempos modernos, proclamou Nicholas Murray Butler (...)” Tradução livre.

${ }^{9}$ A popularidade historicamente adquirida pela sociedade anônima justifica-se pelas faculdades que a sua constituição propicia aos seus participantes. Conforme explica Richard Posner: "The firm is a method of organizing production; the corporation is a method, like a bond indenture, for attracting capital into the firm". POSNER, Richard A.. Economic Analysis of Law. $5^{\text {th }}$ Ed.. New York: Court Little Brown and Company, 1998. p. 451. "A empresa é um método de organização da produção: a companhia, um método, como uma debênture, de se capitalizar a empresa" Tradução livre.
} 
"It's both subjective - an aspect of human experience - and objective - a fact in society. Like love, it can be intensively personal. Or it can be vastly and diffusively inclusive. In its personal aspect, it is a continuing phenomenon of history, politics and human organization" $" 10$.

Assim, negar-lhe existência ou desperceber o poder como produto e, sobretudo, formulador da realidade social, significa ignorá-lo em seu exercício. Isso, em especial, no que tange ao exercício do poder econômico e de suas conseqüências sociais: "Economic power now become a crucial factor in our study. Exploration of its nature is inescapable"11-12.

Diante de sua imprescindibilidade, cabe ainda diferi-lo de figuras que lhe são próximas e, com o poder, facilmente confundíveis. Conforme explica Fábio Konder Comparato, o poder, ao contrário da influência dominante, se exerce através da coerção, por meio da capacidade de sancionar aquele que ao seu encontro resiste ${ }^{13}$. Sobre a relação entre os conceitos de poder e força, o autor explica:

"Ao contrário da influência, a força prescinde da adesão voluntária dos sujeitos que submete. Ao revés do poder, não se assenta no direito, mas na capacidade de dominação de fato. A oposição concreta entre poder jurídico e força fáctica, no entanto, é sempre transitória e anormal. Em regra, força e poder se combinam e se exaltam, mutuamente"14.

Da relevância que o poder adquire para a compreensão da sociedade anônima e de seus elementos infere-se a premissa em que se baseia o presente estudo. A fim de que o direito alcance as finalidades que se the pode prescrever e, sobretudo, num contexto sociocultural marcado pela crescente

\footnotetext{
${ }^{10}$ BERLE, Adolf A.. Power. $1^{\text {st }}$ Ed.. New York: Harcourt, Brace \& World Inc., 1969. p. 21. "É tanto subjetivo - um aspecto da vida humana - como objetivo - um fato social. Como o amor, o poder pode ser intensivamente pessoal. Ou pode ser grandiosa e vastamente inclusivo. Em seu aspecto pessoal, o poder é um fenômeno contínuo da história, da política e da organização humana" Tradução livre.

${ }^{11}$ Id., Power without property: a new development in American Political Economy. $1{ }^{\text {st }}$ Ed.. New York: Harcourt, Brace \& World Inc., 1959. p. 77. "O poder econômico tornou-se um fator crucial em nosso estudo. A exploração da sua natureza é inescapável”. Tradução livre.

${ }^{12}$ COMPARATO, Fábio Konder; FILHO, Calixto Salomão. O Poder de Controle na Sociedade Anônima. $4^{\text {a }}$ Ed.. Rio de Janeiro: Editora Forense, 2005. p. 21.

${ }^{13}$ Ibid. p. XV.

${ }^{14}$ Ibid. p. XV.
} 
complexidade das interações humanas ${ }^{15}$, é fundamental que o direito regule o exercício do poder em muitas de suas dimensões, ou naquilo que, diante dos objetivos passíveis de serem endereçados pelo regulador, se compreenda necessário. Disso resulta a importância em se reconhecê-lo, poder, para que, de acordo com as exigências decorrentes da convivência social, se lhe regule o exercício. Assim se fez através do movimento de positivação do direito societário, cujos possíveis objetivos e instrumentos regulatórios relacionados à transferência de poder de controle são, em sua natureza e regulação, discutidos ao longo deste estudo.

Além das dimensões que o poder de controle apresenta na sociedade anônima, observam-se os muitos significados genericamente atribuídos ao termo. As tantas acepções que o verbete 'controle' etimológica e culturalmente apresenta apontam a essa mesma compreensão. Desde autores que remetem à origem francesa do verbete 'contrôl' e ao seu significado como sinonímia de fiscalização, até os que endereçam à tradição anglo-saxônica, atribuindo-lhe a conotação de capacidade decisória, entende-se que, adotada qualquer das duas acepções, o controle é privilegiado por sua centralidade na compreensão das relações internas e externas à sociedade anônima ${ }^{16}$. Assim se constata através de rasa observação dos ordenamentos jurídicos contemporâneos.

\footnotetext{
${ }^{15}$ Conforme observa Luis Roberto Barroso, as alterações hermenêuticas promovidas no campo do direito no contexto pós-positivista levaram à releitura dos princípios retores que regem à aplicação e a importancia do direito em sua positividade: os "novos papéis reconhecidos à norma, ao problema e ao intérprete decorrem de fatores diversos, dentre os quais se podem assinalar: (i) a melhor compreensão de fenômenos que sempre existiram, mas não eram adecuadamente elaborados; (ii) a maior complexidade da vida moderna, assinalada pela pluralidade de projetos existenciais e de visões de mundo, que comprometem as sistematizações abrangentes e as soluções unívocas para os problemas". BARROSO, Luis Roberto. A Reconstrução do Direito Público no Brasil: In: A Reconstrução Democrática do Direito Público no Brasil. Org. BARROSO, Luis Roberto. Rio de Janeiro: Editora Renovar, 2007. p. 13.

${ }^{16}$ COMPARATO, Fábio Konder; FILHO, Calixto Salomão. Op. cit., p. 27.
} 
As diferenças que os conceitos de 'poder' e 'controle' semanticamente apresentam não se limitam, no entanto, ao estudo afeto ao direito comparado ou ao significado que é atribuído ao termo em sistemas jurídicos distintos. As peculiaridades da utilização de ambos os termos estendem-se, também, internamente a um mesmo ordenamento jurídico. Evidencia-se, assim, a necessidade de se delinear ambos os conceitos em suas acepções e dimensões para que seja possível relacioná-los ao contexto em que se propõe observá-los ou, aqui especificamente, à transferência de controle na sociedade anônima.

Funde-se o poder ao controle. Alcança-se, mediante a influência recíproca entre ambos os termos, a seguinte simples e importante localização do poder de controle na sociedade anônima:

"Every unit of human society demands an ultimate governor, a person upon whom devolves the final decisions by and for the entity. The corporate entity is no different. The contrôleur, as the final voice in the hierarchy of corporate affairs, possesses by metaphysical necessity the obligation and hence the right to establish and then implement the broadest corporate policy. It is impossible for a corporation to be without a contrôleur. In him necessarily rests the guidance of the entity" ${ }^{\prime 17}$.

Tamanho o alcance do poder de controle na companhia, que se observa a vastidão e complexidade das temáticas relacionadas ao seu exercício. Essas vão muito além das situações de sua transferência a um terceiro, discutidas ao longo deste estudo, estendendo-se, desde a delimitação da esfera de atuação do controlador, até a conseqüente delineação de seus deveres frente aos demais participantes da sociedade anônima, sempre diante da subjetivação do controlador como tal.

\footnotetext{
${ }^{17}$ BAYNE, David Cowan. Op. cit., p. 23. "Toda unidade da sociedade demanda um último governante, uma pessoa a quem cabe tomar as decisões finais pela e para a entidade. A companhia não é diferente. O controlador, como voz final na hierarquia dos assuntos da sociedade, possui, por uma necessidade metafísica, a obrigação e, consequientemente, o direito de determinar e implementar as mais amplas diretrizes para a companhia. É impossível para a companhia existir sem um controlador. É nele que, necessariamente, reside a condução da entidade" Tradução livre.
} 
Um dos principais desafios aos juristas que se ocupam da matéria societária consiste em definir quais e, em especial, de quem são os interesses merecedores de tutela pelo ordenamento jurídico na transferência de controle na sociedade anônima. Isso, diante dos inúmeros objetivos passíveis de serem perseguidos por meio do direito societário. Neste trabalho, concentra-se na análise da funcionalidade da transferência de controle na sociedade anônima, muito embora se permita fazer remissões à utilização de ambos os conceitos, 'poder' e 'controle', em áreas outras do direito, a fim de delineá-los em seus fundamentos. Vale-se, assim, da máxima de que cabe ao pesquisador utilizar aqueles que, dentre tantos possíveis vieses e instrumentos metodológicos e diante do que especificamente se propõe analisar lhe permitam uma melhor compreensão do seu objeto de estudo. No caso, da realidade do poder de controle em suas diversas manifestações na sociedade anônima.

Dentre as inúmeras dimensões do poder na sociedade anônima, opta-se por analisar a sua transferência e as implicações sociais que dela advêm. Mais especificamente, busca-se compreender as conseqüências e potencialidades econômico-sociais que lhe são relacionadas, e como ambas essas perspectivas afetam a regulação da transferência do poder de controle no direito societário. Para tanto, nos dois primeiros capítulos deste estudo, são respectivamente delineados os conceitos de 'poder' e 'controle', a fim de se melhor compreender como ambos, juntamente observados no conceito de 'poder de controle', se apresentam na regulação da sociedade anônima.

No terceiro capítulo, analisa-se criticamente o histórico da regulação da sociedade anônima, com destaque aos valores que orientaram a sua estruturação. Apresentadas as premissas que legitimam o direito societário, sugere-se a sua releitura, em atenção aos pressupostos de uma análise dita funcional do direito, por ter a eficiência como máxima valorativa na regulação do exercício da companhia. É à luz do conceito econômico de 'problemas' ou 
'conflitos de agência', observáveis entre os participantes da sociedade anônima e inerentes à sua estrutura, que são classificados os instrumentos regulatórios e de governança das relações decorrentes da companhia. São estes os principais fundamentos teóricos utilizados na análise desenvolvida nas duas etapas subseqüentes deste trabalho.

No quarto capítulo, são estudados três dos principais elementos que integram o estudo funcional das operações de transferência de controle na sociedade anônima. Em primeiro lugar, é delineado o conceito daquilo que Paul Davies e Klaus Hopt denominam transações de controle', à luz dos problemas de agência da companhia. Categoria integrada pelas duas espécies de transferência de controle objeto do presente ensaio: a cessão de controle acionário e a oferta pública à sua aquisição. Em seguida, são discutidas a desejabilidade econômico-social da transferência de controle da companhia e a natureza e consequiências da atribuição do prêmio correspondente ao controle da sociedade anônima. O estudo do terceiro e último elemento destacado no capítulo 4 deste ensaio, ou das estratégias de defesa à tomada de poder de controle diante de uma oferta pública à sua aquisição, é realizado através de uma análise econômico-jurídica sobre a sua legitimidade. Para tanto, privilegiam-se os instrumentos teóricos da análise funcional do direito, bem como seus elementos axiológicos na discussão dos interesses passíveis de serem perseguidos pelo regulador, não obstante o diálogo com escolas doutrinárias outras que, por endereçarem a finalidades distintas, divergem a respeito dos termos em que a transferência de controle na sociedade anônima e a utilização de estratégias de defesa à sua tomada hostil devem prosperar.

Nas duas primeiras etapas do quinto e último capítulo desse estudo, são caracterizadas as modalidades de transferência de poder de controle na sociedade anônima compreendidas na categoria de transações de controle proposta por Paul Davies e Klaus Hopt, respectivamente: a cessão de controle 
acionário e a oferta pública à sua aquisição. Apresentados os objetivos a que o regulador pode remeter ao prescrever os termos sobre os quais ambas as operações devem ser realizadas, evidenciam-se as semelhanças e, sobretudo, as distinções que os ordenamentos jurídicos apresentam no tocante à regulação das operações de transferência de controle na sociedade anônima. Em especial, são enfatizadas as diferenças entre os ordenamentos analisados no que se refere à alocação do poder decisório sobre a realização de tais operações. Explica-se: pretende-se compreender como as estratégias regulatórias e de governança que integram a leitura dita 'funcional' das relações societárias aqui proposta são utilizadas na regulação da transferência de controle na sociedade anônima. Isso, a fim de se minimizar os conflitos existentes entre agentes e principais, bem como os custos de agência decorrentes da estruturação regulamentar das modalidades de transferência de controle.

Caracterizadas ambas as modalidades de transferência de controle, passa-se, no último item do capítulo 5, à análise do ordenamento jurídico brasileiro e, em especial, do entendimento da Comissão de Valores Mobiliários - CVM, sobre a configuração da alienação de controle para fins de incidência do regime legal que lhe é aplicável. Mais especificamente, são delineadas as características consolidadas nos precedentes da CVM sobre a exegese do artigo 254-A, da Lei $n^{\circ}$ 6.404, de 15 de dezembro de 1976, ou de modo a ensejar a realização da oferta pública de aquisição - OPA, obrigatória, por parte do adquirente, aos acionistas com direito de voto na sociedade anônima, e decorrente da alienação do controle acionário.

Por fim, conclui-se se é a adoção de pressupostos distintos por cada escola metodológica observada, bem como de objetivos diversos a serem endereçados pelo direito societário, acrescidos à influência exercida na sua positivação pelos agentes econômicos, que justificam a existência de sistemas 
jurídicos inteiramente distintos a respeito da transferência de controle na sociedade anônima. 


\section{Capítulo 1 - A realidade do poder na sociedade anônima}

"No better comparison - whether technical or otherwise could be employed to express the custodial relationship of the contrôleur to the corporation. No child is more completely in the care of a parent than is the corporation when under the total dominion of the contrôleur" ${ }^{\prime 18}$ (Bayne, 1966).

\subsection{O poder soberano na sociedade anônima: uma proposta de leitura 'constitucional' do poder de controle}

"A disciplina da sociedade anônima constitui, atualmente, o autêntico "direito constitucional" da atividade econômica, no setor privado" "19 (Fábio Konder Comparatto, 2005).

O estudo da manifestação de poder na sociedade anônima é elementar à melhor compreensão tanto do fenômeno social fundado na personificação da atividade econômica organizada, como das conseqüências que dele advêm. Essa observação estende-se, desde a subjetivação dos participantes da sociedade anônima e da delineação de suas respectivas competências, até a positivação do regime de responsabilidade que é aplicável a cada parte integrante da companhia. Isso, de modo a se, regulamentarmente, possibilitar a realização daquilo que se convencionou como a função social da sociedade anônima ${ }^{20}$.

\footnotetext{
${ }^{18}$ Id., A Legitimate Transfer of Control, $\mathrm{n}^{\circ}$ 18. Stanford: Stanford Law Review, 1966. p. 438. Ap. Ibid. p. 4. "Nenhuma comparação melhor - independentemente se técnica ou não, poderia ser adotada para expressar a relação de custódia que existe entre o controlador e a companhia. Nenhuma criança está mais aos cuidados dos pais, do que a companhia está sob o total domínio do controlador" Tradução livre.

${ }^{19}$ COMPARATO, Fábio Konder; FILHO, Calixto Salomão. Op. cit., p. XVI.

${ }^{20} \mathrm{O}$ artigo 116, da Lei ${ }^{\circ}$ 6.404/76, prescreve, em seu parágrafo único, o dever do acionista controlador da sociedade anônima de exercer o controle em correspondência à função social da sociedade anônima: "O acionista controlador deve usar o poder com o fim de fazer a companhia realizar o seu objeto e cumprir sua função social, e tem deveres e responsabilidades para com os demais acionistas da empresa, os que nela trabalham e para com a comunidade em que atua, cujos direitos e interesses deve lealmente respeitar e atender." O fundamento constitucional à função social do exercício da sociedade anônima corresponde aos princípios que devem reger a atividade econômica. Conforme o inciso III, do art. 170, da Constituição da República Federativa do Brasil, de 5 de outubro de 1988: "A ordem econômica, fundada na valorização do trabalho humano e na livre iniciativa, tem
} 
Nesta análise, é fundamental que se atente para os elementos decorrentes do exercício do poder, que sobrepujam o campo do direito societário e alcançam áreas outras das ciências sociais, mostrando-se ampla e genericamente em suas tantas dimensões. Disto resulta um instrumental que proporciona, por meio de comparações e analogias, a delineação do 'poder' ao contexto em que se propõe observá-lo.

A necessidade de se disciplinar o poder não se limita, no entanto, à sua capacidade sancionadora. Sua tendência à concentração, mais evidente no estudo do direito concorrencial, justifica-o como objeto regulatório primo de outras áreas do direito, no que não é excepcionado por sua vertente societária. Explica Fábio Konder Comparato:

"No campo econômico, a concentração do poder acentuou-se sobremaneira, a partir da revolução industrial, acarretando transformações sociais de que ainda não nos demos conta, integralmente (...)"21.

Por esta razão, é fundamental que se negue ao poder o puro arbítrio, sob pena de excepcioná-lo às limitações que, principiologicamente, existem no ordenamento jurídico e à luz das exigências impostas pela convivência social $^{22}$. Concebê-lo, ainda, como fato extrajurídico impassível de ser regulamentado é omitir-se frente à realidade própria do poder em sociedade. Disto se infere que, quando o poder se defronta com interesses tutelados pelo ordenamento jurídico, cumpre ao regulador restringi-lo em seu exercício.

No entanto, antes da ontológica característica do poder, de tender à concentração, percebe-se a sua grave e simples inevitabilidade. Assim explica Adolf Berle:

por fim assegurar a todos existência digna, conforme os ditames da justiça social, observados os seguintes princípios: função social da propriedade".

${ }^{21}$ COMPARATO, Fábio Konder; FILHO, Calixto Salomão. Op. cit., p. XVI.

${ }^{22}$ HESSE, Konhad. A Força Normativa da Constituição. Porto Alegre: Editora Safe, 1991. p. 20 
"Power is always preferable to anarchy: tyrannical order is less noxious than chaos. When there is a power vacuum, it will inevitably be filled. In such a condition, any individual capable of doing so is bound to take power (...),23.

Diferentemente do que se observa na abordagem típica ao direito concorrencial ao tratar do abuso do poder econômico que vise à dominação de mercados ${ }^{24}$, o poder na sociedade anônima não se concentra simplesmente, mas sim se dissolve na estrutura própria da companhia. É através da identificação do titular do poder de controle na sociedade anônima que se lhe pode atribuir os direitos e responsabilidades que correspondam à titularidade do poder $^{25}$.

Resulta o poder em duas de suas principais dimensões: como instrumento disponível a quem o detenha de sancionar aquele que diante de si não sucumba (característica em que difere da mera influência) e de assim fazê-lo, sob a tutela do direito (no que se distingue da força fática). Desta noção conjunta: de poder como capacidade jurídica de se impor uma determinada vontade, dotada da capacidade de sancionar quem diante de si resista, passa-se à sua localização na estrutura da sociedade anônima.

\footnotetext{
${ }^{23}$ BERLE, Adolf A.. Power. Op. cit., p. 29. "O poder é sempre preferível à anarquia: uma ordem tirânica é menos nociva que o caos. Aonde exista um vácuo de poder, o mesmo será inevitavelmente preenchido. Nessas condições, qualquer indivíduo capaz de fazê-lo é tentado a tomar o poder (...)" Tradução livre.

${ }^{24}$ A CRFB/88 prevê, no $\S 4^{\circ}$ de seu art. 173, a repressão ao poder econômico exercido abusivamente, ou que vise à dominação dos mercados, à eliminação da concorrência ou ao aumento arbitrário dos lucros, regulamentada pela Lei ${ }^{\circ}$ 8.884, de 11 de junho de 1994: “A lei reprimirá o abuso do poder econômico que vise à dominação dos mercados, à eliminação da concorrência e ao aumento arbitrário dos lucros".

25 Como justifica Fábio Konder Comparato: "Trata-se, em primeiro lugar, de reconhecer, explicitamente, a necessidade do poder, como elemento fundamental da economia societária. Trata-se, ademais, de disciplinar-lhe o exercício, assinando ao seu titular os deveres e responsabilidades de que, tradicionalmente, se considera desvinculado por completo". COMPARATO, Fábio Konder; FILHO, Calixto Salomão. Op. cit., p. XVII. Com efeito, no ordenamento jurídico brasileiro, são distintos os requisitos e regimes jurídicos previstos na regulação do controle para fins de aplicação das disciplinas previstas nos artigos 117 e 254-A. Enquanto se exige o efetivo exercício do controle para que se possa responsabilizar o seu titular por abuso de poder de controle, basta a mera transferência da titularidade do controle acionário para que se exija, de seu adquirente, realizar a oferta pública obrigatória prevista no artigo 254-A da Lei das Sociedades por Ações. A discussão sobre a disciplina jurídica aplicável a essas duas dimensões do controle na sociedade anônima é objeto dos capítulos 4 e 5 deste trabalho.
} 
Por muito, sustentou-se que o poder soberano na sociedade anônima identificava-se ao da assembléia geral. O artigo 122, da Lei n ${ }^{0} 6.404$, de 15 de dezembro de 1976, prevê a competência exclusiva da assembléia geral para a deliberação de certas matérias. De modo a propiciar o equilíbrio do exercício de poder nas relações internas à companhia, o caput do artigo 139 e o parágrafo $7^{\circ}$ do artigo 163, ambos da Lei das Sociedades por Ações, prescrevem que, além da competência inderrogável da assembléia geral prevista em seu artigo 122, as atribuições legalmente conferidas aos diretores, administradores e fiscais da sociedade anônima não podem ser outorgadas a outro órgão, independentemente da forma de sua constituição ${ }^{26}$.

Conforme destaca Fábio Konder Comparato, os órgãos hierarquicamente organizados que compõem a sociedade anônima não o fazem senão tendo como vértice a assembléia geral. Esta pode ser entendida como órgão societário primário, imediato, mas que, por sua vez, não se confunde com a companhia que integra ${ }^{27}$. Previsto como o responsável por investir de poderes aos demais órgãos da sociedade anônima, compete à assembléia geral, mediante o exercício dos acionistas e por meio do direito de voto, tanto a nomeação dos membros do conselho de administração da companhia, cuja competência inclui a de indicar os diretores que presentam a sociedade ${ }^{28-29}$, quanto à destituição dos conselheiros, como a expressão da vontade social ${ }^{30-31}$. É essa a posição do autor:

\footnotetext{
${ }^{26}$ COMPARATO, Fábio Konder; FILHO, Calixto Salomão. Op. cit., p. 31.

${ }^{27}$ MIRANDA, Pontes. Tratado de Direito Privado, $3^{\text {a }}$ Ed.. Vol. L, Rio de Janeiro: Borsoi, 1972, § 5.315, 1. Ap. COMPARATO, Fábio Konder; FILHO, Calixto Salomão. Op. cit., p. 31.

${ }^{28}$ Assim prevê o artigo 142, II, da Lei no 6.404/76: "Compete ao Conselho de Administração: eleger e destituir os diretores da companhia e fixar-lhes as atribuições, observado o que a respeito dispuser o estatuto".

${ }^{29}$ A Lei $n^{\circ} 6.404 / 76$ prescreve, no parágrafo $1^{\circ}$ de seu artigo 138 , a competência exclusiva da diretoria na 'representação' da companhia. No entanto, prefere-se adotar a terminologia originariamente proposta por Pontes de Miranda, que diferencia as figuras da representação e da presentação, sendo essa típica à pessoa jurídica, posto que, como ficção jurídica, é incapaz de atuar por si mesma.

${ }^{30}$ COMPARATO, Fábio Konder; FILHO, Calixto Salomão. Op. cit., p. 31.
} 
"Nesse sentido estritamente jurídico, nem sempre coincidente com a realidade econômica, ela é sem dúvida, o poder supremo da companhia, como diz o Código das Obrigações suíço (art. 698), ou o órgão supremo, como preferiu declarar a Lei Geral mexicana de sociedades mercantis (art. 178)" ${ }^{, 32}$.

Aproximam-se, assim, as acepções de soberania atribuídas à assembléia geral na sociedade anônima e ao poder de controle. Fábio Konder Comparato remete à realidade do poder própria ao direito constitucional, a fim de criticar a concepção de supremacia do direito de voto do acionista na sociedade anônima:

"A declaração constitucional de que "todo poder emana do povo e em seu nome é exercido", por exemplo, tem se apresentado mais como enunciado de princípio, de valor programático, do que como disposição efetivamente vinculante na prática política, onde a noção de "povo" se revela excessivamente abstrata. Analogamente, na pesquisa da realidade de poder, na sociedade anônima, não nos podemos contentar com a afirmação legal de que a "a assembléia geral, convocada e instalada de acordo com a lei e o estatuto, tem poderes para decidir todos os negócios relativos ao objeto da sociedade e tomar as resoluções que julgar conveniendates à sua defesa e desenvolvimento" (Lei 6.404, art. 121)"33.

\section{E atenta o autor:}

"É generalizada, porém, a ignorância do fenômeno do poder, no direito acionário. Até há pouco, o modelo legal, ao qual ainda aderiam doutrina e jurisprudência, concebia as companhias como destitdaduídas de mando ou controle predeterminado, admitindo que os negócios sociais fossem decididos, em assembléia, por uma maioria formada ad hoc, após amplos debates e momentânea deliberação" ${ }^{\text {34 }}$.

Da tese sobre a identificação da titularidade do poder de controle na assembléia geral decorrem críticas sobre a possibilidade de se impor limitações ao dito 'fundamental' direito de voto do acionista na assembléia geral. Nesta perspectiva, alega-se que a soberania interna da companhia

\footnotetext{
${ }^{31}$ A primeira parte do caput do artigo 140 , da Lei $n^{0}$ 6.404/76, assim dispõe sobre a competência da assembléia geral de, a qualquer tempo, indicar e destituir os membros do conselho de administração da sociedade anônima: "O conselho de administração será composto por, no mínimo, 3 (três) membros, eleitos pela assembléia-geral e por ela destituíveis a qualquer tempo". Em seu lugar, a primeira parte do caput do art. 143, da Lei $\mathrm{n}^{\circ}$ 6.404/76, atribui, aos membros do conselho de administração, a competência para eleger e destituir os diretores da sociedade anônima e, diante da ausência do conselho de administração, confere à assembléia geral essa prerrogativa: "A Diretoria será composta por 2 (dois) ou mais diretores, eleitos e destituíveis a qualquer tempo pelo conselho de administração, ou, se inexistente, pela assembléia-geral".

${ }^{32}$ COMPARATO, Fábio Konder; FILHO, Calixto Salomão. Op. cit., p. 31.

${ }^{33}$ Ibid. p. 39.

${ }^{34}$ Ibid. p. XVII.
} 
somente pode ser exercida pelos acionistas mediante a garantia do exercício de direito de voto na assembléia geral. Assim e, tendo em vista a sua alegada fundamentalidade, por muito se defendeu como ilegítima a utilização de qualquer instrumento que pudesse restringir o exercício de direito de voto por qualquer acionista da sociedade ${ }^{35}$. Explica Fábio Konder Comparato:

"Daí decorria a disciplina da assembléia geral e do exercício do voto como um verdadeiro direito eleitoral, quando a realidade quotidiana não cessava de desmentir essa concepção "parlamentar". Surpreende, ainda, como novidade, a idéia simples de que não há sociedade sem controle, assim como não existe empresa sem empresário"36.

A fim de se constatar a validade dos pressupostos em que se funda esse raciocínio, é imprescindível destacar o que o ordenamento jurídico brasileiro prescreve ao tratar da competência da assembléia geral da sociedade anônima:

"A assembléia geral, convocada e instalada de acordo com a lei e o estatuto, tem poderes para decidir todos os negócios relativos ao objeto da sociedade e tomar as resoluções que julgar convenientes à sua defesa e desenvolvimento"37.

Inevitável reproduzir as palavras do próprio autor sobre a realidade do poder na sociedade anônima: "A definição de poder de comando é sempre feita em função da assembléia geral, que constitui a última instância societária" ${ }^{38}$. E complementa:

"Quem toma, de fato, as decisões da assembléia? O controle se manifesta através dos poderes decisórios da assembléia de acionistas como necessária legitimação do seu exercício. Mas essa legitimação é meramente formal ou procedimental"39.

Dissolve-se, enfim, o mito da democracia assemblear na sociedade anônima. Reconhece-se, ainda, o poder de controle externo, não só à assembléia geral, como à própria companhia.

\footnotetext{
${ }^{35}$ EIZIRIK, Nelson. Reforma da Lei das S.A. $2^{\text {a }}$ Ed. Rio de Janeiro: Editora Renovar, 1998. p. 37 e ss. ${ }^{36}$ COMPARATO, Fábio Konder; FILHO, Calixto Salomão. Op. cit., p. XVII.

${ }^{37}$ É essa a redação do art. 121 da Lei n $\mathrm{n}^{\circ}$ 6.404/76: "A assembléia geral, convocada e instalada de acordo com a lei e o estatuto, tem poderes para decidir todos os negócios relativos ao objeto da companhia e tomar as resoluções que julgar convenientes à sua defesa e desenvolvimento".

${ }^{38}$ Ibid. p. 39.

${ }^{39}$ Ibid. p. 39
} 
Prossegue-se à realidade do poder na sociedade anônima.

\title{
1.2 McCulloch v. Maryland (1819): a aplicação da doutrina dos poderes implícitos no direito constitucional norte-americano vis-à-vis as teorias da 'business judgment rule' e dos 'implied corporate powers'
}

\author{
"Power tends to corrupt and absolute power tends to \\ corrupt absolutely" (Lord Acton, 1887) ${ }^{40}$.
}

A observação da manifestação de poder e de suas limitações impostas nos diversos âmbitos do direito mostra-se útil para se delinear o seu conteúdo à luz das relações que se pode fazer entre a sua disciplina em outras matérias e a que se propõe observá-lo. Em especial, são muitas as analogias passíveis de serem feitas entre o exercício de poder no âmbito do direito constitucional e a sua realidade na sociedade anônima. Dentre elas, de modo a facilitar a sua compreensão e, de acordo com o objeto do presente estudo, destaca-se a restrição muitas vezes imposta pelas legislações de distintos ordenamentos aos órgãos jurisdicionais em analisar, a posteriori, o mérito das decisões tomadas por um dos demais poderes políticos, no escopo de suas respectivas competências constitucionais. Da mesma forma, a apreciação judicial realizada no âmbito da sociedade anônima restringe-se à analise dos aspetos formais das decisões adotadas pelos órgãos que integram a administração da companhia, em conformidade com a sua competência legal e estatutária e em função do office ocupado ${ }^{41}$.

A teoria dos poderes implícitos, desenvolvida ao longo da história constitucional norte-americana, reza que, além dos poderes expressamente

\footnotetext{
${ }^{40}$ Ap. BORK, Robert H.. The tempting of America: the political seduction of the law. New York: The Free Press, 1990. p. 141. "O poder tende a corromper. O poder absoluto tende a corromper absolutamente" Tradução livre.

${ }^{41} \mathrm{O}$ conceito de 'office' aqui utilizado refere-se à filosofia de poder de controle desenvolvida por David Cowan Bayne. Genericamente, o autor atribui ao verbete 'office' o significado de autoridade ou função. BAYNE, David Cowan. Op. cit., p. 145. A aplicabilidade do conceito de office na sociedade anônima é especificamente estudada no item 2.4 deste estudo, quando se discute a localização do poder de controle na sociedade anônima.
} 
atribuídos ao Congresso pela Constituição norte-americana de 17 de setembro de 1787 sob a seção 8 , de seu artigo $1^{\circ}$, foram conferidos poderes outros ao Congresso Nacional daquele país e que também decorreriam da denominada cláusula do comercio ${ }^{42}$. Nos Estados Unidos, a aplicação do conceito de 'poderes implícitos' à realidade da sociedade anônima levou a jurisprudência e a doutrina à construção conceitual análoga dos 'implied corporate powers' ${ }^{43}$, cuja compreensão auxilia na aplicação da business judgement rule no direito societário.

Em 1819, no julgamento de McCulloch v. Maryland, o Chief Justice John Marshall endereçou a opinião da Corte no célebre caso em que foi questionada a competência do Congresso Nacional em constituir um banco federal, diante da ausência de menção expressa no texto constitucional atribuindo-lhe essa prerrogativa:

"We admit, as all must admit, that the powers of the government are limited, and that its limits are not to be transcended. But we think the sound of construction of the constitution must allow to the national legislature that discretion, with respect to the means by which the powers it confers are to be carried into execution, which will enable that body to perform the high duties assigned to it, in the manner most beneficial to the people. Let the end be legitimate, let it be within the scope of the constitution, and all means which are appropriate, which are plainly adapted to that end, which are not prohibited, but consist with the letter and spirit of the constitution, are constitutional (...)",44.

\footnotetext{
${ }^{42}$ A esse respeito, confrontaram-se os federalistas Alexander Hamilton, favorável a uma interpretação extensiva das prerrogativas constitucionalmente conferidas ao Congresso norte-americano e James Madison, oposto a esse entendimento. Para um adágio entre os autores: O' BRIEN, David M.. Constitutional Law and Politics: struggles for power and governmental accountability. $6^{\text {th }}$ Ed.. Vol. I. New York: Norton \& Company, 2005. p. 522/525.

43 Analogamente à doutrina dos poderes implícitos construída no direito constitucional norteamericano, são reconhecidos, aos participantes da sociedade anônima os poderes decorrentes da função que exercem na companhia e inerentes à constituição da sociedade anônima. Explica Kenneth Clarkson: "Certain implied powers arise when a corporation is created. Barring express constitutional, statutory, or charter prohibitions, the corporation has the implied power to perform all acts reasonably appropriate and necessary to accomplish its corporate purposes". CLARKSON, Kenneth W. et. al. Op. cit., p. 767. "Certos poderes implícitos nascem quando uma companhia é criada. Exceto diante da existência de proibições constitucionais, legais e estatutárias, a companhia tem os poderes implícitos para realizar quaisquer atos razoavelmente apropriados e necessários à realização de seu objeto social" Tradução livre.

${ }^{44}$ O' BRIEN, David M.. Op. cit., p. 534. "Nós admitimos, como todos devem admitir, que os poderes do governo são limitados, e que esses limites não devem ser transpostos. Mas nós pensamos que a
} 
Do reconhecimento de poderes implicitamente conferidos pela Constituição ao Congresso Nacional para a realização de suas atribuições, entendeu-se que lhe caberia, discricionariamente, adotar os meios que considerasse mais adequados para alcançar as finalidades que lhe competem, à luz do que dispõe o texto constitucional ${ }^{45}$. Assim aponta John Marshall a seguir na decisão:

"But where the Law is not prohibited, and is really calculated to effect any of the objects entrusted to the government, to undertake here to inquire into the degree of its necessity, would be to pass the line which circumscribes the judicial department, and to tread on legislative ground. This court disclaims all pretensions to such a power, ${ }^{, 6}$.

Unanimemente, os juízes da Suprema Corte norte-americana entenderam que se excluem da apreciação do Judiciário os atos exercidos pelo Congresso Nacional dentro de sua competência constitucional. Seja através do exercício de poderes implícitos, decorrentes do reconhecimento de prerrogativas não-expressamente atribuídas pela Constituição; explícitos, por sua previsão literal no texto constitucional; ou inerentes, pois conseqüentes da

lógica da construção da constituição deve permitir ao poder legislativo a discrição, com respeito aos meios em que os poderes que lhe são conferidos devem ser executados, de modo a permitir àquele organismo exercer os altos deveres que lhe são assinalados, na forma mais benéfica ao povo. Deixe-se o fim ser legítimo e se encontrar no escopo da constituição, e todos os meios que são apropriados e plenamente adaptados àquele fim e não são proibidos, mas sim consistentes com a letra e o espírito da constituição, devem ser compreendidos como constitucionais" Tradução livre.

45 A Constituição norte-americana prevê, na seção 8 de seu art. $1^{\circ}$, a competência atribuída ao Congresso Nacional. Destaca-se o último parágrafo do dispositivo que enuncia, como atribuição prevista ao Congresso, a de: "To make all the Laws which shall be necessary and proper for carrying into Execution the foregoing Powers, and all other Powers vested". O' BRIEN, David M.. Op. cit., p. 5. "Elaborar todas as leis necessárias e apropriadas ao exercício dos poderes acima especificados e dos demais que a presente Constituição confere ao Governo dos Estados Unidos, ou aos seus Departamentos e funcionários". Tradução disponível em

$<$ http://www.embaixadaamericana.org.br/index.php?action=materia\&id=643\&submenu=106\&itemme nu=110>.Acesso em 4 jul. 2008.

${ }^{46}$ Ibid. p. 535. "Mas aonde a Lei não é proibitiva, e é elaborada para afetar qualquer dos objetos confiados ao governo, em adotar aqui para adentrar no grau de necessidade de sua atuação, seria cruzar a linha que circunscreve o poder judiciário e atuar na seara legislativa. Essa corte dispensa toda e qualquer pretensão relacionada a tal poder” Tradução livre. 


competência atribuída ao Congresso Nacional segundo a carta
constitucional $^{47}$.

De maneira análoga, a jurisprudência dos Estados Unidos construiu, no escopo do direito societário, o que chamou de 'business judgment rule'. Essa consiste na restrição imposta à atividade jurisdicional em apreciar decisões regularmente tomadas pelos órgãos de gestão da companhia, na condução dos negócios sociais. No julgamento de Aronson v. Lewis, realizado em 1984, os juízes da Suprema Corte do Estado de Delaware definiram a 'business judgement rule' como:

"A presumption that in making a business decision the directors of a corporation acted on an informed basis, in good faith and in the honest belief that the action taken was in the best interests of the company" ${ }^{48}$.

\footnotetext{
${ }^{47}$ Sobre o conceito de poderes implícitos, é imprescindível a remissão a 'Marbury v. Madison' 1 Cr. (5 U.S.) 137, julgado pela Suprema Corte em 1803. No caso, John Marshall entendeu legítimo o exercício do poder de judicial review como inerente à competência atribuída pelo art. $3^{\circ}$, da Constituição norteamericana ao Judiciário: "It is emphatically the province and duty of the judicial department [the judicial branch] to say what the law is. Those who apply the rule to particular cases, must of necessity expound and interpret that rule. If two laws conflict with each other, the courts must decide on the operation of each. So if a law [e.g., a statute or treaty] be in opposition to the constitution: if both the law and the constitution apply to a particular case, so that the court must either decide that case conformably to the law, disregarding the constitution; or conformably to the constitution, disregarding the law: the court must determine which of these conflicting rules governs the case. This is of the very essence of judicial duty. If then the courts are to regard the constitution; and the constitution is superior to any ordinary act of the legislature; the constitution, and not such ordinary act, must govern the case to which they both apply". O' BRIEN, David M.. Op. cit., p. 54. "É enfaticamente o dever do poder judiciário dizer o que o direito é. Aqueles que aplicam a regra em casos particulares devem, necessariamente, expor e interpretar a regra jurídica. Se duas leis estiverem em conflito entre si, as cortes devem decidir sobre a aplicação de cada uma. Então, se a norma jurídica (por exemplo, um código ou um tratado) estiver em oposição à constituição e se tanto a regra jurídica quanto a constituição são aplicáveis a uma determinada situação, então aquela corte deve ou decidir o caso em conformidade com a norma, independentemente da constituição, ou em conformidade com a constituição, independentemente da norma: a corte deve determinar qual dessas regras conflitantes rege o caso. Essa é a essência da atividade jurisdicional. Se as cortes devem guardar a constituição; e a constituição é superior a qualquer outro ato ordinário do legislativo, a constituição, e não tal ato ordinário, deve reger o caso em que ambos sejam aplicáveis” Tradução livre.

${ }^{48}$ VELASCO, Julian. The Enduring Illegitimacy of the Poison Pill. University of Notre Dame, The Law School. p. 383. Disponível em <http://papers.ssrn.com/sol3/papers.cfm?abstract_id=825046>. Acesso em 12 set. 2007. "Uma presunção que, na tomada uma decisão relacionada à condução dos negócios sociais, os diretores de uma companhia devem agir dispondo de um grau adequado de informação, com boa fé e com a crença sincera de que a decisão adotada o foi no melhor interesse da companhia" Tradução livre.
} 
Essa regra de interpretação dos negócios sociais deve ser compreendida negativamente, como uma limitação imposta ao órgão judicante em, valorativa e posteriormente, apreciar o mérito das decisões adotadas pelos administradores da sociedade anônima, em conformidade com suas respectivas competências: "a court will not substitute its judgment for that of the board if the latter's decision can be "attributed to any rational business purpose $^{,, 49}$.

Não cabe a valoração da correção das decisões regularmente adotadas pelos administradores da companhia, seja diretamente realizada pelo poder judiciário, ou pelo órgão administrativo ab initio competente para apreciá-las. À autoridade judicante cabe tão-somente prezar pelo atendimento aos critérios legais, regulamentares e estatutários previstos aos gestores da sociedade anônima, e não substituir o juízo dos administradores pelo seu próprio sobre a conveniência das decisões sociais adotadas. Sintetiza Kenneth Clarkson: "If there is reasonable basis for a business decision, a court is unlikely to interfere with that decision, even if the corporation suffers as a result ${ }^{\prime \prime 50}$.

No ordenamento brasileiro, observa-se a restrição imposta à autoridade judicante em responsabilizar o administrador por prejuízos decorrentes do regular exercício das atividades negociais em dois dispositivos da Lei das Sociedades por Ações. Dispõe a primeira parte de seu artigo 158: “o administrador não é pessoalmente responsável pelas obrigações que contrair em nome da sociedade e em virtude de ato regular de gestão”. Por sua vez, em seu artigo 159 , parágrafo $6^{\circ}$, que trata da ação de responsabilidade social, a Lei $\mathrm{n}^{\mathrm{o}}$ 6.404/76 prevê que: "O juiz poderá reconhecer a exclusão da responsabilidade do administrador, se convencido de que este agiu de boa-fé e

\footnotetext{
${ }^{49}$ Ibid. p. 383. Sinclair Oil Corp. v. Levien. Delaware Supreme Court, 280 A.2d 717, 720 (1971). “A Corte não substituirá o julgamento da diretoria da sociedade pelo seu, se à decisão adotada, puder ser "atribuído qualquer propósito racional relacionado ao objeto da companhia"" Tradução livre.

${ }^{50}$ CLARKSON, Kenneth W. et. al. Op. cit., p. 792.
} 
visando ao interesse da companhia", resssalvando-se que a expressão 'poderá', presente no dispositivo, refere-se a um verdadeiro poder-dever da autoridade judicante, em face das hipóteses de responsabilização do administrador previstas no artigo 158 anterior, quais sejam: a sua atuação dolosa ou culposa, ou em violação à lei ou estatuto.

Mesmo em campos jurídicos distintos, aproximam-se ambas as figuras. A restrição imposta ao poder judiciário de apreciar os atos dos demais entes políticos, em atenção aos limites da competência a todos conferida pela carta constitucional, aproxima-se à aplicação da business judgment rule na interpretação dos negócios da sociedade anônima. Dentre tais negócios sociais e de acordo com o objeto do presente estudo, encontram-se os relativos à transferência de poder de controle na sociedade anônima.

É nesse mesmo sentido que se observa a correlação entre as restrições à modificação externa da estrutura de um dos entes políticos constitucionalmente instituídos e dos órgãos responsáveis pela administração da sociedade anônima.

\subsection{O 'Court-Packing Plan' rooseveltiano (1937) e as restrições na alteração da estrutura da diretoria na sociedade anônima em $M M$. Companies Inc. v. Liquid Áudio, Inc. (2003)}

Durante a história constitucional norte-americana, foram muitos os presidentes que contrapuseram o poder exercido pela Suprema Corte dos Estados Unidos. Em uma dessas ocasiões, Franklin Delano Roosevelt, após ver grande parte da legislação que compunha o 'New Deal' ser declarada inconstitucional pela Suprema Corte ao longo de seu primeiro mandato, exercido entre os anos de 1933 e 1937, submeteu à aprovação do Congresso norte-americano uma proposta para alterar a composição daquela Corte. 
Em 5 de fevereiro de 1937, após sua expressiva reeleição e em resposta às sucessivas decisões que considerava contrárias aos anseios sociais, Franklin Delano Roosevelt apresentou a proposta que a opinião pública chamou de “Court-Packing Plan”. O plano consistia no aumento do número de juízes da Suprema Corte dos Estados Unidos, através da atribuição de pares àqueles que alcançassem uma determinada faixa etária. Pode-se extrair das justificativas publicamente apresentadas para a adoção do plano que a finalidade principal a que o mesmo se destinava era a de, mediante a alteração da composição da Suprema Corte, ter garantida a maioria dentre seus membros integrantes, na apreciação de parte fundamental da legislação que integrou o New Deal ${ }^{51-52}$.

Conforme denota a própria história constitucional norte-americana, a fim de evitar que o plano presidencial fosse concretizado, a Suprema Corte daquele país alterou o seu entendimento manifestado no julgamento de Lochner v. New York, Adkins v. Children's Hospital of D.C., e Morehead v. New York ex rel. Tipaldo, respectivamente julgados em 1905, 1923 e 1926, no que diz respeito à competência do Congresso norte-americano sob a seção 8 do artigo $1^{\circ}$, da Constituição de $1787^{53}$.

\footnotetext{
${ }^{51}$ Em discurso à população norte-americana realizado em 1937, Franklin Delano Roosevelt assim justificou a medida: "We have, therefore, reached the point as a Nation where we must take action to save the Constitution from the Court and the Court from itself. We must find a way to take an appeal from the Supreme Court to the Constitution itself. We want a Supreme Court which will do justice under the Constitution - not over it. In our Courts we want a government of laws and not of men". O’BRIEN, David M.. Op. cit., p. 65. "Chegamos a um ponto como Nação em que devemos agir para salvar a Constituição da Corte e a Corte de si mesma. Devemos encontrar um meio de recorrer da Suprema Corte à própria Constituição. Queremos uma Suprema Corte que faça justiça sob a Constituição, e não sobre a mesma. Em nossas Cortes, desejamos um governo de leis e não de homens" Tradução livre.

${ }^{52}$ Ibid. p. $559 / 560$.

${ }^{53}$ Para a discussão sobre os motivos à superação destes precedentes: HOMBERGER, Jacob. Economic Liberty and the Constitution, Part 12, 2003. Disponível em <http://www.fff.org/freedom/fd0305a.asp>. Acesso em 10 fev. 2008.
} 
Superados os precedentes que antes limitavam a competência do Congresso Nacional frente às legislaturas estaduais ${ }^{54}$, a Suprema Corte dos Estados Unidos manteve-se com a sua composição inalterada ${ }^{55}$. Consolidouse, assim, não só parte substancial da legislação integrante do New Deal, como também o provérbio que, historicamente, marcou a mudança de decisão manifestada pelo juiz Owen J. Roberts da Suprema Corte norte-americana em West Coast Hotel Co. V. Parrish, julgado em 1937, como "a switch-in-timethat-saved-nine"

\footnotetext{
${ }^{54} \mathrm{Na}$ opinião majoritária endereçada pela Suprema Corte em Planned Parenthood of Southeastern Pennsylvania v. Casey 505 U.S. 833112 S.Ct. 2791, em 1992, os juízes da Suprema Corte fundamentaram a sua decisão com base nos precedentes relacionados a Lochner e superados em West Coast: "The first example is that line of cases identified with Lochner v. New York 198 U.S. 45 (1905), which imposed substantive limitations on legislation limiting economic autonomy in favor of health and welfare regulation, adopting, in Justice Holmes's view, the theory of laissez-faire. The Lochner decisions were exemplified by Adkins v. Children's Hospital of D.C., 261 U.S. 525 (1923), in which this Court held it to be an infringement of constitutionally protected liberty of contract to require the employers of adult women to satisfy minimum wage standards. Fourteen years later, West Coast Hotel Co. V. Parrish, 300 U.S. 379 (1937), signaled the demise of Lochner by overruling Adkins. In the meantime, the Depression had come and, with it, the lesson that seemed unmistakable to most people by 1937, that the interpretation of contractual freedom protected in Adkins rested on fundamentally false factual assumptions about the capacity of a relatively unregulated market to satisfy minimal levels of human welfare (...)" O'BRIEN, David M.. Constitutional Law and Politics - Civil Rights and Civil Liberties, $6^{\text {th }}$ Ed. Vol. II. New York: Norton \& Company, 2005. p. 1263. "O primeiro exemplo é a linha de casos identificados com Lochner v. New York 198 U.S. 45. (1905), que impuseram limitações substantivas na legislação que limitou a autonomia econômica, em favor da regulação da saúde e do bem-estar social, adotando, na perspectiva do Justice Holmes, a teoria do "laissez-faire". As decisões Lochner foram exemplificadas por Adkins v. Children's Hospital of D.C. 261 U.S. 525 (1923), em que a Corte decidiu que infringia a constitucionalmente protegida autonomia da vontade de exigir que empregadores de mulheres adultas lhes assegurassem uma remuneração mínima. Quatorze anos mais tarde, West Coast Hotel Co. V. Parrish, 300 U.S. 379 (1937) assinalou que a decisão em Lochner era obsoleta, superando Adkins. Entre essas decisões, ocorreu a grande depressão e, com a mesma, a lição que parecia inequívoca à maior parte da população em 1937, de que a interpretação sobre a liberdade de contratar protegida em Adkins baseava-se em assunções fáticas fundamentalmente falsas sobre a capacidade de mercados relativamente não-regulados satisfazerem níveis mínimos de qualidade para a vida humana" Tradução livre.

${ }^{55} \mathrm{O}$ enunciado da seção 8 do artigo $1^{\circ}$, da Constituição norte-americana que se refere à competência do Congresso Nacional em: "To regulate commerce with foreign nations, and among the several states, and with the Indian tribes". Disponível em

<http://www.law.cornell.edu/constitution/constitution.articlei.html>. Acesso em 1 dez. 2007. "Regular o comércio com as nações estrangeiras, entre os diversos estados, e com as tribos indígenas" Tradução disponível em

$<$ http://www.embaixadaamericana.org.br/index.php?action=materia\&id=643\&submenu=106\&itemme nu=110>. Acesso em 3 jul. 2008.

${ }^{56}$ O'BRIEN, David M. Constitutional Law and Politics - Civil Rights and Civil Liberties, $6{ }^{\text {th }}$ Ed. Vol. I. Op. cit., p. 62/67. Em contraponto à tradicional definição de 'stare decisis”, instituto originário do
} 
Até hoje, resta a polêmica sobre a constitucionalidade da medida proposta pelo então presidente Franklin Delano Roosevelt, vis-à-vis à garantia constitucional de independência do Poder Judiciário ${ }^{57-58}$. Salvo doutrinariamente, a proposta de se alterar o número de juizes que compunham a Suprema Corte não chegou a ser enfrentada. Ao final, o objetivo a que o plano se destinava já havia sido alcançado pela alteração do entendimento da Corte sobre a constitucionalidade da legislação federal em questão ${ }^{59}$.

No caso MM. Companies Inc. v Liquid Áudio Inc., julgado em 2003 pela Suprema Corte do Estado de Delaware, foi questionada a legalidade da deliberação favorável ao aumento do número de diretores de uma sociedade tomada pelos seus então membros, previamente à indicação de dois diretores

tronco da Common Law, David O'Brien remete à colocação do Justice Robert Jackson a respeito da perenidade dos precedentes e que, perfeitamente, se adequa à superação dos casos oriundos de Lochner: "Stare decisis and the precedential value of the Court's jurisdictional doctrines and policies, as Justice Jackson in half-jest quipped, "are accepted only at their current valuation and have a mortality rate as high as their authors"'. O'BRIEN, David M. Constitutional Law and Politics - Civil Rights and Civil Liberties, $6^{\text {th }}$ Ed. Vol. I. Op. cit., p. 126. "Stare decisis e o valor como precedente das decisões e construções judiciais, como o Justice Jackson comentou: "são aceitas somente em seu valor atual e têm a taxa de mortalidade tão alta como a de seus criadores"”' Tradução livre.

${ }^{57}$ No Artigo $n^{\circ} 78$ dos 'Federalistas', Alexander Hamilton já expressava a preocupação pelo exercício independente da atividade jurisdicional pelo poder judiciário: "it proves, in the last place, that as liberty can have nothing to fear from the judiciary alone, but would have every thing to fear from its union with either of the other departments; (...) The complete independence of the courts of justice is peculiarly essential in a limited Constitution". Disponível em

$<$ http://www.yale.edu/lawweb/avalon/federal/fed78.htm>. Acesso em 9 fev. 2008. "Finalmente, isso prova que a liberdade não deve ter nada a temer do judiciário em si, mas deve ter tudo a temer de sua união com qualquer dos demais poderes políticos, (...) A completa independência das cortes é essencial para a existência do estado de direito" Tradução livre.

${ }^{58}$ Assim se previu na seção 1 do art. $3^{\circ}$, da Constituição norte-americana: "The judicial power of the United States shall be vested in one Supreme Court, and in such inferior courts as the Congress may from time to time ordain and establish. The judges, both of the supreme and inferior courts, shall hold their offices during good behaviour, and shall, at stated times, receive for their services, a compensation, which shall not be diminished during their continuance in office". Disponível em $<$ http://www.law.cornell.edu/constitution/constitution.articlei.html>. Acesso em 1 dez. 2007. "O Poder Judiciário dos Estados Unidos será investido em uma Suprema Corte e nos tribunais inferiores que forem oportunamente estabelecidos por determinações do Congresso. Os juízes, tanto da Suprema Corte como dos tribunais inferiores, conservarão seus cargos enquanto bem servirem, e perceberão por seus serviços uma remuneração que não poderá ser diminuída durante a permanência no cargo". Tradução disponível em

$<$ http://www.embaixadaamericana.org.br/index.php?action=materia\&id=643\&submenu=106\&itemme nu=110>. Acesso em 3 jul. 2008.

${ }^{59}$ Para a análise crítica do assunto, O'BRIEN, David M.. Constitutional Law and Politics - Civil Rights and Civil Liberties, $6^{\text {th }}$ Ed., Vol. I. Op. cit., p. 559/560. 
pelos acionistas minoritários. A peculiaridade do caso é que se constatou como a potencial influência que os novos diretores exerceriam quando eleitos, especificamente na qualidade de representantes indicados pelos acionistas minoritários, seria anulada, diante do aumento do número total de membros da diretoria da sociedade.

Foi o seguinte o fundamento da decisão manifestada pela Corte:

"Maintaining a proper balance in the allocation of power between the stockholders' right to elect directors and the board of directors' right to manage the corporation is dependent upon the stockholders' unimpeded right to vote effectively in an election of directors" $"$.

A pertinência em se restringir a possibilidade de se, deliberadamente, alterar a composição da mesa diretora da companhia e que, segundo a Lei societária brasileira, é composta por membros indicados pelos conselheiros de administração no que tange à sociedade de capital aberto ${ }^{61}$ relaciona-se à preservação da representatividade dos acionistas e de seus interesses na gestão dos negócios sociais. Especificamente com relação à transferência de controle na sociedade anônima, observa-se a importância dessa restrição, tal como no bojo do direito constitucional, sobretudo nas hipóteses de deliberação dos administradores da companhia em se adotar estratégias de defesa, diante da tentativa de se tomar o controle da companhia por meio de uma oferta pública à sua aquisição e que, aqui, se discute no capítulo 4.

Por tais razões, restringe-se a validade de proposições que visem a alterar a forma de representação dos acionistas na mesa diretora da companhia tão-somente das fundadas num interesse social que assim as justifique:

\footnotetext{
${ }^{60}$ CLARKSON, Kenneth W et. al. Op. cit., p. 787. "Manter um adequado equilíbrio na alocação de poderes entre o direito dos acionistas de indicar os diretores e o direito da mesa diretora da sociedade de administrar a companhia depende do exercício efetivo do direito conferido aos acionistas em, efetivamente, votar na eleição dos diretores" Tradução livre.

${ }^{61}$ Dispõe o artigo 142, II, da Lei $n^{\circ}$ 6.404/76: "Compete ao conselho de administração: eleger e destituir os diretores da companhia e fixar-lhes as atribuições, observado o que a respeito dispuser o estatuto".
} 
"When the primary purpose of a board of directors [action] is to interfere with or impede the effective exercise of the shareholder franchise [voting rights] in a contested election for directors, the board must first demonstrate a compelling justification for such action as a condition precedent to any judicial consideration of reasonableness and proportionality" ${ }^{2}$.

Por tais razões, os juízes da Suprema Corte do Estado de Delaware entenderam que a proposta de aumentar o número de diretores da sociedade anônima sem uma justificativa elementar e necessária seria contrária ao direito de voto e representação garantido aos acionistas, atendidos os direitos conferidos pelas ações aos seus titulares e a proporção de sua participação no capital social.

Aproximam-se os questionamentos sobre a legalidade de medidas análogas ao Court Packing Plan rooseveltiano àquelas realizadas no escopo da sociedade anônima. Assim entendeu a Suprema Corte do Estado de Delaware, ao julgar como ilegal a proposta prescindível de alteração da estrutura da mesa diretora da sociedade anônima, pois restritiva à representatividade de determinados grupos acionários na administração da companhia.

A definição da real fonte de poder de controle na sociedade anônima, juntamente aos critérios de aplicação da business judgment rule e das diversas relações que o estudo do poder de controle em sua transferência possui frente a ciências afins, auxiliam na análise das limitações impostas na apreciação $a$ posteriori da legalidade das decisões tomadas pelos administradores na gestão da sociedade anônima. Dentre tais decisões, destacam-se, de acordo com o objeto deste estudo, a de transferir o controle da sociedade, quando de

\footnotetext{
${ }^{62}$ CLARKSON, Kenneth W. et. al. Op. cit., p. 787. "Quando o principal objetivo da ação adotada pela mesa diretora da companhia for interferir ou impedir o exercício efetivo do direito conferido aos acionistas de eleger os membros da diretoria da companhia numa eleição em que divirjam os acionistas, a diretoria deve demonstrar uma justificativa fundamental para a sua ação, como uma condição que prescindirá qualquer consideração judicial de razoabilidade e proporcionalidade da medida adotada" Tradução livre.
} 
titularidade dos próprios administradores e a de adotar instrumentos de defesa a uma oferta hostil de tomada de poder de controle.

É à luz do conceito do poder de controle e de sua localização na sociedade anônima realizada a seguir, que, nos capítulos subseqüentes, lançase a tais considerações. 


\title{
Capítulo 2 - 0 controle: conceito, localização e classificação no direito societário
}

\begin{abstract}
"Of the whole complex of individuals having interests in an enterprise, only those are called owners who have major interests and, before the law, only those who hold legal title. Similarly, the term control must be limited for practical purposes to those who hold the major elements of power over an enterprise, keeping in mind, however, that a multitude of individuals may exercise a degree of power over the activities of an enterprise without holding sufficient power to warrant their inclusion in "control" 63 (Berle $\mathrm{e}$ Means, 1969).
\end{abstract}

\subsection{O controle e as suas acepções no direito societário}

O estudo das muitas acepções que o conceito de 'controle' apresenta no direito societário é imprescindível à compreensão de diversas temáticas elementares ao funcionamento da sociedade anônima, no caso, à de sua transferência. Fábio Konder Comparato remete à origem francesa do verbete 'contrerole' o qual historicamente, explica o autor, era originariamente grafado pela justaposição da preposição 'contre' e do verbete latino 'rotulus', cuja redação, já no século XVI, passou para a forma atual 'role', e que deu origem ao atual 'contrôle' do direito francês ${ }^{64}$.

Conforme elucida Fábio Konder Comparato, são três os significados atribuídos pelo Dicionário da Academia Francesa ao verbete 'controle':

"Relação nominal das pessoas pertencentes a um corpo ou a uma tropa (cet oficier a été rayé dês controles de l'armée; dresser lê contrôle d'une compagnie; vous êtes porté sur lê contrôle); marca, atestando o contraste de obras de ouro ou de prata (cette pièce de vaisselle est suspect, elle n'a pas lê contrôle; tous les ouvrage d'orgêvrrerie sont soumis au

\footnotetext{
${ }^{63}$ BERLE. Adolf A.; MEANS, Gardiner C., The Modern Corporation and Private Property, Rev. Ed. New York: Brace \& World Inc, 1969. P. 113. "De todos os indivíduos que possuem interesse no exercício da companhia, somente aqueles que se pode chamar de proprietários possuem interesses ditos maiores e, assim, sob o direito, são somente os mesmos que figuram na qualidade de acionistas da companhia. Da mesma forma, o termo 'controle' deve ser limitado, por razões práticas, àqueles que apresentem os principais elementos de poder sobre a companhia, tendo em vista que, em seu lugar, um grupo de indivíduos pode exercer um grau de poder sobre as atividades da companhia, sem que possuam poder suficiente para garantir a sua participação no controle social” Tradução livre.

${ }^{64}$ COMPARATO, Fábio Konder; FILHO, Calixto Salomão. Op. cit., p. 27.
} 
contrôle); verificação, sobretudo na linguagem administrativa (être chargé de l'inspection et du contrôle d'une perception, d'une comptabilité, d'une caísse). No figurado, significa exame ou censura. E nesse sentido básico de verificação ou fiscalização que o direito francês fala, classicamente, em contrôle des sociétes anonymes" ${ }^{\$ 15}$.

Nesse mesmo sentido apontam as letras germânicas. O significado de 'Kontrolle' no idioma alemão é o de fiscalização e inspeção, e a adoção do termo no ordenamento jurídico germânico segue dessa mesma sorte. Assim destaca o autor: "No $§ 17$ da lei acionária de 1965, fala-se de empresas subordinadas e de empresas dominantes (Abhaengige und herrschende Unternenhmen) e no $\S 291$, do contrato de dominação entre empresas (Beherrschungsvertrag)" ${ }^{\text {66 }}$.

A disciplina dos grupos empresariais desenvolvida no ordenamento germânico (Konzern) refere-se, ainda, ao que Adolf Berle e Gardiner Means categorizam como os três níveis em que a estrutura de poder na sociedade anônima se estabelece: o da participação no capital ou investimento acionário; o de direção; e, ao que aqui é mais importante, o de controle ${ }^{67}$.

O grupo econômico de subordinação (Unterordnungskonzern) tem como característica elementar a unidade de controle. Já o grupo econômico denominado 'de coordenação’ ou 'igualitário' (Gleichordnungskonzern) ocorre quando sociedades juridicamente autônomas, muito embora sem relação de subordinação, são reunidas sob direção unitária. Nesse sentido e de modo a diferenciar a unidade de direção à de controle, a exposição de motivos

\footnotetext{
${ }^{65}$ Fábio Konder Comparato nota que, em atenção à acepção francesa de controle, o Código das Obrigações Suíço, em sua versao em francês: "denomina contrôleurs os conselheiros fiscais de uma sociedade por ações (arts. 697 e ss.)” Ibid. p. 28.

${ }^{66}$ Ibid. p. 29.

67 "In discussing problems of enterprise it is possible to distinguish between three functions: that of having interests in an enterprise, that of having power over it, and that of acting with respect to it. A single individual may fulfill, in varying degrees, any one or more of these functions". BERLE, Adolf A.; MEANS, Gardiner C.. Op. cit., p. 112. Ap. Ibid. p. 41. "Na discussão sobre os problemas de um negócio, é possível distinguir três dimensões distintas: a primeira, relacionada às participações que se pode ter na companhia; a segunda, sobre o poder que se exerce sobre a sociedade; e a terceira, relacionada às ações sobre a mesma. Um mesmo indivíduo pode exercer, em diversos graus, uma ou mais dessas funções" Tradução livre.
} 
do Konzern dispõe que: "essa harmonização [no grupo econômico de coordenação ou igualitário] não pressupõe nenhum direito de comandar" ${ }^{\text {,68 que }}$ é característico ao grupo econômico de subordinação no qual as sociedades que o compõem encontram-se sujeitas a um feixe comum de poder. Da classificação proposta por Adolf Berle e Gardiner Means se extrai, ainda, a importante conclusão sobre a localização do controle na sociedade anônima. Conforme comentado, embora a propriedade acionária possa determinar o real titular do controle da companhia, a mesma não se identifica com as duas outras dimensões de poder na sociedade anônima reconhecidas no ordenamento jurídico alemão: de direção ou de controle. Esse entendimento é especialmente importante ao estudo desenvolvido nos itens seguintes deste capítulo, em que se discute a localização do controle na sociedade anônima, e, posteriormente, sua categorização.

Segundo a língua inglesa, a concepção do verbete 'control' é distinta da francesa. Aqui confere-se ao controle o significado de capacidade decisória, de poder ou dominação. É ainda Fábio Konder Comparato quem exemplifica a utilização do termo nesta acepção, de modo a ilustrar como, segundo a tradição anglo-saxônica, compreende-se o conteúdo de controle:

"Fala-se, assim, de parental control como sinônimo de pátrio poder; alude-se à dominação do homem sobre a natureza (man's increasing control over nature) sobre si mesmo (self-control), sobre suas aptidões (have control of several languages). Num sentido mais atenuado, controle também é sinônimo de regulação (prices, wages or rent control). $\mathrm{O}$ sinônimo mais aproximado de control é power, da mesma forma que o verbo to control, aproxima-se de to conduct ${ }^{\prime \prime 69}$.

Mesmo apreendidas as influências que ambas as acepções de 'controle' exerceram sobre a positivação do termo no direito societário brasileiro, seja de seu significado como sinonímia de fiscalização, segundo a sua raiz francesa,

\footnotetext{
${ }^{68}$ Ibid. p. 42.

${ }^{69}$ Ibid. p. 28/29.
} 
ou como domínio ${ }^{70}$, de acordo com o tronco anglo-saxônico, é especificamente a essa segunda utilização - de controle como poder - que este estudo irá se referir ao tratar da transferência de controle na sociedade anônima ${ }^{71}$.

\title{
2.2 A localização do controle no direito societário contemporâneo
}

\begin{abstract}
"It is no more anomalous that shareholders do not manage or control "their" corporation than the boldholders do not manage or control the corporations whose bonds they hold, or trust beneficiaries the trustee. All these groups have an investment interest. The difference lies in the greater vulnerability of the shareholder (as of the trust beneficiary) than of the bondholder to misfeasance and nonfeasance by corporate management. Since the bondholder has a fixed interest rate (and, for what it is worth, the cushion of the equity investment)" ${ }^{\text {"72 }}$ (Berle e Means, 1967).
\end{abstract}

Diante da multiplicidade do fenômeno do controle na sociedade anônima e da conseqüente impossibilidade em se definir genérica e previamente a posição de quem o exerce, resta a tarefa de se delinear as

\footnotetext{
${ }^{70}$ Ressalve-se que o conceito de controle como domínio não se confunde com a figura do domínio característica e objeto de estudo dos direitos reais, e decorrente da propriedade. Em remissão à definição de Lafayette, Caio Mário da Silva Pereira conceitua dominus como: "Direito real que vincula legalmente e submete ao poder absoluto de nossa vontade a coisa corpórea na substância, acidentes e acessórios". LAFAYETTE, Direito das Coisas, § 24. Apud. PEREIRA, Caio Mário da Silva. Instituições do Direito Civil. $20^{\mathrm{a}}$ Ed., Vol. IV, Rio de Janeiro: Editora Forense, 2006. p. 91

${ }^{71}$ A alínea ' $b$ ' do art. 116, da Lei $n^{\circ}$ 6.404/76, ao subjetivar o acionista controlador, assim dispõe: "Entende-se por acionista controlador a pessoa, natural ou jurídica, ou o grupo de pessoas vinculadas por acordo de voto, ou sob controle comum, que: usa efetivamente seu poder para dirigir as atividades sociais e orientar o funcionamento dos órgãos da companhia." Acresce-se, ao enunciado do dispositivo, o presente em sua alínea 'a', que contempla aquilo em que o direito britânico centrou-se para subjetivar o titular do poder de controle. Nesse sistema jurídico, subjetiva-se o controlador como aquele capaz de determinar a composição da board of directors. Adicionando-se lhe a estabilidade em seu exercício, ou a capacidade permanente de obtenção da maioria nas deliberações da assembléia geral, e conjuntamente ao que dispõe a alínea 'b' do art. 116, da Lei $n^{\circ}$ 6.404/76, no direito societário brasileiro, o controlador é definido como aquele que: "é titular de direitos de sócio que lhe assegurem, de modo permanente, a maioria dos votos nas deliberações da assembléia geral e o poder de eleger a maioria dos administradores da companhia" (Lei n ${ }^{0}$ 6.404/76, artigo 116, alínea 'a').

${ }^{72}$ BERLE, Adolf A.; MEANS, Gardiner C.. Op. cit., p. 67 e ss. Apud. COMPARATO. Fábio Konder; FILHO, Calixto Salomão. Op. cit., p. 52. "Não surpreende o fato de que os acionistas não administram ou controlam "sua" companhia, assim como os debenturistas não administram ou controlam a companhia cujos títulos possuam, ou, ainda, os beneficiários de um trust com relação ao trustee. Todos esses grupos possuem interesses relacionados aos seus investimentos. A diferença entre eles encontrase na maior vulnerabilidade que o acionista (tal como o beneficiário do trust) possui em relação ao debenturista pela má-gestão da administração da companhia. Inclusive pelo fato do debenturista possuir uma taxa de retorno fixa (e, pelo seu valor, a proteção de seu investimento)" Tradução livre.
} 
principais características do controle para que se possibilite a subjetivação de seu titular, e que, assim, se lhe sejam atribuídas as obrigações decorrentes do controle $\mathrm{e}^{73}$.

São muitas as dimensões que o controle apresenta. Localizado entre posição jurídica e situação de fato ${ }^{74}$, e como origem real do exercício de poder na sociedade anônima, o controle adquire inúmeras acepções, de acordo com as características de seu exercício. Alguns autores o conceituam de forma estrita, posicionando-o internamente à companhia. David Cowan Bayne identifica o controle ao 'office' da sociedade anônima, subjetivando a figura do controlador como aquele que, plenamente, o exerça. Desse sentido de controle como função e autoridade, decorre que a sua transferência é compreendida pelo autor como um "agreement for the naked transfer of corporate office ${ }^{\mathrm{p75}-76}$.

Em referência à obra de Túlio Ascarelli, Fábio Konder Comparato destaca a atipicidade como característica inerente ao controle na sociedade anônima:

"Enquanto a participação de uma sociedade no capital da outra constitui uma relação jurídica típica, o controle não corresponde a uma situação jurídica determinada, mas a uma situação de fato, que pode derivar de várias relações jurídicas, levando-se em consideração não só o tipo de relação, como também as modalidades de fato correspondentes à situação

\footnotetext{
${ }^{73}$ A discussão sobre a natureza e os distintos regimes jurídicos aplicáveis ao controle em duas de suas dimensões: a responsabilidade por seu exercício e a configuração da alienação de controle para fins de realização da oferta pública de aquisição obrigatória é realizada ao longo dos capítulos 4 e 5 deste estudo.

${ }^{74}$ Ibid. p. 67.

7575 BAYNE, David Cowan. Op. cit., p. 98. [a transferência do controle pode ser entendida como] "um acordo para a transferência integral do office da sociedade anônima" Tradução livre.

${ }^{76}$ BAYNE, David Cowan. Op. cit., p. 98. Ressalve-se que o conceito de 'sale of office' a que o autor se refere é distinto do tradicionalmente adotado pela doutrina com relação à venda, pelos administradores, de sua posição como agentes nomeados por seus principais, ou pelos acionistas que os indicaram. A respeito das razões à típica vedação legal à prática do que a doutrina denomina como 'sale of office', e que não se confunde ao conceito de transferência de controle decorrente da alienação do 'office', adotado por David Cowan Bayne: EASTERBROOK, Frank H.; FISCHEL, Daniel R.. The Economic Structure of Corporate Law. London: First Harvard University Press, 1996. p. 132/134.
} 
comparativa dos diferentes interessados na vida da sociedade" ${ }^{, 77}$. Dessa característica, entretanto, não se infere ao controle a sua insignificância à esfera jurídica, pois, "enquanto situação de fato, pode constituir o pressuposto de aplicação de determinadas normas (uma conditio júris, diríamos nós) ${ }^{\text {,78 }}$.

Do reconhecimento do caráter atípico e inafastável do poder de controle $^{79}$ em relação à sociedade, acrescido da imprescindibilidade em se regulamentá-lo em muitas das dimensões de seu exercício, prossegue-se à sua localização. Aqui, são reveladas as inúmeras classificações e subclassificações que, ao longo da história, foram propostas ao estudo do controle. No entanto, antes de classificar o controle na sociedade anônima, discutem-se, preliminarmente, os fundamentos dos denominados 'problemas de agência', objeto do item 3.4 deste ensaio, na medida em que consistem na base metodológica adotada para a análise funcional da transferência de controle na sociedade anônima realizada em seguida.

Um dos principais atributos da companhia consiste na faculdade conferida aos seus participantes de separar a administração da sociedade anônima da titularidade acionária. Esta dissociação tornou-se possível mediante a possibilidade dos agentes econômicos delegarem a condução dos negócios sociais da companhia àqueles que considerassem mais aptos para a organização e gestão da empresa sob a sociedade constituída. Isso de modo a lhes atribuir melhores resultados na realização do objeto social da companhia, em comparação aos que adviriam, caso a administração da sociedade, necessariamente, competisse aos próprios acionistas.

\footnotetext{
${ }^{77}$ ASCARELLI, Túlio. Riflessioni in tema di Titoli Azionari e Societá tra Societá. In: Banca, Borsa e Titoli di Credito, 1952, 1, p. 385. Ap. COMPARATO, Fábio Konder; FILHO, Calixto Salomão. Op. cit., p. 47.

${ }^{78}$ Ibid. p. 47.

${ }^{79}$ Conforme ressalvado no final do item 2.1. deste estudo, opta-se por, aqui, privilegiar o conceito de controle como poder, permitindo-se o neologismo resultante da expressão 'poder de controle' como sinonímia de ambos: 'poder' e 'controle'.
} 
Ainda no século XVIII, Adam Smith alertou sobre os problemas decorrentes da dissociação entre propriedade e controle. $\mathrm{O}$ autor defendia que a sociedade anônima seria necessariamente menos eficiente que modelos societários outros em que propriedade e controle se identificassem na figura do administrador, tais como a sole proprietorship do direito anglo-saxônico ${ }^{80-}$ ${ }^{81}$. Esta ineficiência resultaria justamente da delegação, a terceiros, da gestão da sociedade de propriedade dos acionistas e que se refere aos problemas ou conflitos de agência discutidos no item 3.4 deste estudo. No exercício desse modelo representativo na companhia, sustentava o autor: "Negligence and profusion, therefore, must always prevail" ${ }^{\prime 82}$.

Ao tratar da dissociação entre propriedade e controle, Fábio Konder Comparato explica:

"A grande novidade trazida pela sociedade acionária foi a possibilidade de concentrar o poder econômico, desvinculando-o da propriedade dos capitais e da responsabilidade pessoal; de organizar tanto a macroempresa, quanto a exploração unipessoal; de ensejar o exercício da atividade empresária pelo Estado, em concorrência com os particulares", 83 .

E conclui:

"O problema fundamental da economia moderna não é mais a titularidade da riqueza, mas o controle sobre ela. E é nesse sentido que deve ser interpretada a tese marxista

\footnotetext{
${ }^{80}$ John Micklethwait e Adrian Wooldridge expõem o fundamento das críticas de Adam Smith à delegação possível através da sociedade anônima: "He thought that joint-stock companies were inherently less efficient than sole traders. In particular, he worried about the "agency" problem: hired managers would not bring the same "anxious vigilance" to their firms' interests as ownersmanagers". Ap. MICKETHWAIT, John; WOOLDRIDGE, Adrian. Op. cit., p. 34. "Ele [Adam Smith] acreditava que as sociedades com mais de um participante seriam necessariamente menos eficientes que as empresas individuais. Particularmente, ele se preocupava com o problema de agência em se contratar administradores que não empregariam a mesma diligência com relação aos interesses das companhias por eles administradas, assim como o fariam caso, além de administradores, fossem proprietários" Tradução livre.

${ }^{81}$ CLARKSON, Kenneth W. et. al. Op. cit., p. 718 e ss.

${ }^{82}$ SMITH, Adam. Ap. MICKETHWAIT, John; WOOLDRIDGE, Adrian. Op. cit., p. 34. "Negligência e desperdício sempre prevaleceriam" Tradução livre.

${ }^{83}$ COMPARATO. Fábio Konder; FILHO, Calixto Salomão. Op. cit., p. XVI.
} 
acerca da concentração de capital, pois este conceito não designa, nessa teoria, coisas ou bens, nem mesmo uma relação de propriedade, mas uma manifestação de poder"»4.

Supera-se a identidade entre propriedade e controle na sociedade anônima.

Revoluciona-se, assim, o próprio capitalismo.

\subsection{Berle e Means: o controle interno e sua classificação}

"Em todo grupo do tipo societário podemos identificar uma estrutura hierarquizada e uma modalidade própria de poder. Assim, por exemplo, falamos do pátrio poder na família, do poder empresarial na empresa, do poder de direção ou administração em qualquer tipo de associação ou coorporação e do poder disciplinar em qualquer organização formal" ${ }^{\text {85 }}$ (Lamy Filho e Bulhões Pedreira, 1996).

A fim de se contemplar a dissociação operada pela sociedade anônima entre controle e propriedade, Adolf Berle e Gardiner Means propuseram classificar o controle interno ${ }^{86}$ à companhia em cinco categorias principais: o controle exercido através da quase integral propriedade acionária; o controle majoritário; o controle exercido mediante expedientes legais; o controle minoritário; e o controle administrativo ou gerencial ${ }^{87}$.

Em sua primeira categoria, os autores relacionam o controle interno a sociedades inerentemente pessoais ${ }^{88}$. O controle exercido através da quase

\footnotetext{
${ }^{84}$ Ibid. p. XVI.

${ }^{85}$ FILHO, Alfredo Lamy Filho; PEDREIRA, Josë Luiz Bulhões. A Lei das S.A. vol. II, 2a Ed.. Rio de Janeiro: Editora Renovar, 1996. p. 617.

${ }^{86}$ No item 2.4. seguinte deste capitulo, discute-se a natureza do controle externo, em contrapartida ao exercício interno de controle na sociedade anônima, cuja classificação proposta por Adolf Berle e Gardiner Means é estudada a seguir.

${ }^{87}$ BERLE, Adolf A.; MEANS, Gardiner C.. Op. cit., p. 67

${ }^{88}$ A classificação entre sociedades pessoais e de capital refere-se ao caráter prevalente do vinculo existente entre os sócios. Enquanto nas sociedades ditas pessoais, sobressai a figura dos sócios que a integram, nas sociedades ditas de capital e, em especial, na sociedade anônima de capital aberto, mais relevante do que os sócios que integram o quadro de acionistas é o capital com que participaram para a realização do objeto social. Sobre a pertinência prática da classificação para as condições de exercício de determinados direitos pelos sócios, tais como o de retirada, previsto nos artigos 1.077, do Código Civil brasileiro e 137, da Lei $\mathrm{n}^{\circ}$ 6.404/76, respectivamente aos sócios das sociedades limitada e
} 
integral titularidade acionária é aquele existente em sociedades caracterizadas como unipessoais, ou que possuam somente ou praticamente um único sócio. Propriedade e controle, nesses casos, parecem confundir-se, sendo o controle mera decorrência da titularidade acionária ${ }^{89}$.

Já no controle majoritário, evidencia-se aquilo que Adolf Berle e Gardiner Means compreendem como o primeiro passo à dissociação entre propriedade e controle. Aqui, não mais parecem se identificar ambas as figuras. A existência de um bloco majoritário de ações não garante ao seu titular o controle "absoluto" da sociedade, tal qual a propriedade integral ${ }^{90}$.

Com efeito, Fábio Konder Comparato propõe a subdivisão do controle majoritário em controle majoritário simples e controle majoritário absoluto, conforme exista ou não uma minoria qualificada nos termos da lei ou do estatuto social para a aprovação de determinadas deliberações ${ }^{91}$. Esta classificação se mostra oportuna sobretudo para se graduar o nível de controle exercido pelos acionistas que integram o bloco de controle majoritário do

anônima: BORBA, José Edvaldo Tavares. Direito societário. $9^{a}$ Ed.. Rio de Janeiro: Editora Renovar, 2004. p. 68.

${ }^{89}$ Segundo a classificação proposta por Adolf Berle e Gardiner Means, na espécie de controle exercido através da quase integral titularidade acionaria e diferentemente das demais, o controlador figura tanto como titular do real domínio da sociedade, como seu proprietário exclusivo ou praticamente exclusivo. Nessa hipótese, a sua qualidade de dominus mostra-se em suas duas dimensões: pela titularidade do direito de propriedade e do controle da sociedade anônima. Assim se notou no final do item 2.1 deste capítulo, em que se discutiu o conceito de controle.

${ }^{90} \mathrm{O}$ artigo 136, da Lei $\mathrm{n}^{\circ} 6.404 / 76$, prevê as matérias que exigem quorum qualificado para a sua aprovação. Além da possibilidade de se estipular estatutariamente quorum maior do que o previsto no dispositivo para a aprovação das matérias nele enunciadas, ressalva-se, como mínimo legal, a metade do capital votante como quorum de deliberação. Prescreve o artigo: "É necessária a aprovação de acionistas que representem metade, no mínimo, das ações com direito a voto, se maior quorum não for exigido pelo estatuto da companhia cujas ações não estejam admitidas à negociação em bolsa ou no mercado de balcão, para deliberação sobre: I - criação de ações preferenciais ou aumento de classe de ações preferenciais existentes, sem guardar proporção com as demais classes de ações preferenciais, salvo se já previstos ou autorizados pelo estatuto; II - alteração nas preferências, vantagens e condições de resgate ou amortização de uma ou mais classes de ações preferenciais, ou criação de nova classe mais favorecida; III - redução do dividendo obrigatório; IV - fusão da companhia, ou sua incorporação em outra; V - participação em grupo de sociedades (art. 265); VI - mudança do objeto da companhia VII - cessação do estado de liquidação da companhia; VIII - criação de partes beneficiárias; IX - cisão da companhia; X - dissolução da companhia”.

${ }^{91}$ COMPARATO, Fábio Konder; FILHO, Calixto Salomão. Op. cit., p. 63. 
capital da sociedade anônima, de acordo com a possibilidade de, sem a necessidade das demais ações votantes, obter a aprovação de certas deliberações sociais ${ }^{92-93}$.

A categoria de 'controle majoritário' em ambas as suas modalidades, simples e absoluta, pode, por sua vez, ser subdividida de acordo com o número de acionistas que compõem o bloco de controle. No caso de controle compartilhado por uma pluralidade de acionistas, é comum que os mesmos integrem o bloco de controle da sociedade anônima, por representarem um grupo homogêneo de interesses no que tange à condução dos negócios sociais e por assim sê-lo, decidirem exercer conjuntamente o controle na sociedade anônima. A essa modalidade de controle prevista no artigo 116, da Lei $\mathrm{n}^{\mathrm{o}}$ 6.404/76, ao se fazer menção ao termo 'grupo' na subjetivação do acionista controlador $^{94}$, Fábio Konder Comparato denomina ‘controle conjunto' ou 'por

\footnotetext{
${ }^{92}$ Para a classificação do controle majoritário em simples e absoluto, Fábio Konder Comparato trata das situações em que os acionistas minoritários da companhia são capazes de exercerem direitos na gestão e fiscaliação da companhia, através da titularidade de um determinado percentual do capital social. Por exemplo, mediante a disposição de dez por cento do capital votante da companhia, facultase ao minoritário: requerer a adoção do procedimento de voto múltiplo para a eleição dos membros do conselho de administração (art. 141); eleger, em votação separada, um membro do conselho fiscal e seu respectivo suplente (art. $161 \S 4^{\circ}$, a), e que denotam a pertinência em se classificar o controle majoritário em simples e absoluto. Ibid., p. 63.

${ }^{93}$ No julgamento do Processo Administrativo CVM no 2007/11086, realizado em 6 de maio de 2008, o Diretor Marcos Barbosa Pinto manifestou o seu entendimento de que o percentual a que se refere o $\S$ $4^{\circ}$, do art. 161, da Lei $n^{\circ} 6.404 / 76$, para a eleição de membro do conselho físcal e seu respectivo suplente diz respeito tão-somente à existência de ações que não integrem o bloco majoritário de ações e que totalizem pelo menos $10 \%$ do capital social da companhia, e não se confunde ao percentual do capital minoritário que deve estar presente na assembléia geral, para que, assim, se faculte ao acionista minoritário presente exercer o direito previsto no dispositivo, independentemente da parcela do capital social que o mesmo seja titular.

Disponível em <http://www.cvm.gov.br/port/descol/respdecis.asp?File=5633-0.HTM >. Acesso em 5 de jul. de 2008.

${ }^{94}$ Assim dispõe o art. 116, da Lei n ${ }^{0}$ 6.404/76: "Entende-se por acionista controlador a pessoa, natural ou jurídica, ou o grupo de pessoas vinculadas por acordo de voto, ou sob controle comum, que: a) é titular de direitos de sócio que lhe assegurem, de modo permanente, a maioria dos votos nas deliberações da assembléia-geral e o poder de eleger a maioria dos administradores da companhia; e b) usa efetivamente seu poder para dirigir as atividades sociais e orientar o funcionamento dos órgãos da companhia".
} 
associação', assim como o fazem Adolf Berle e Gardiner Means, ao conceituá-la 'joint control' 95 .

$\mathrm{Na}$ classificação proposta pelos autores, a terceira modalidade de controle, 'exercido através de expedientes legais', caracteriza-se como aquela em que seu titular exerce o controle da companhia através de instrumentos especificamente elaborados para esse fim, e não mediante a titularidade da parcela majoritária do capital social votante da sociedade anônima. Exemplos dessa modalidade de controle ilustrada por Adolf Berle e Gardiner Means são as formas de controle piramidal ou em cadeia num grupo societário; a emissão de ações sem direito a voto ou com exercício de voto limitado; e a constituição de um voting trust que permita a seus integrantes o exercício comum do controle social ${ }^{96-97}$.

Mais relevante ao presente estudo é a quarta categoria proposta por Adolf Berle e Gardiner Means, ou ‘controle minoritário'. Seu reconhecimento deriva da compreensão de que, diante de um determinado grau de dispersão acionária, o controle da companhia pode ser exercido individualmente ou em

\footnotetext{
${ }^{95}$ Conforme se destaca da redação do caput, do art. 116, da Lei $\mathrm{n}^{\mathrm{o}}$ 6.404/76, prescinde-se da existência de um acordo de acionistas para o exercício conjunto do controle na sociedade anônima e a fim de se identificar o controlador. A redação do dispositivo é mais ampla nesse sentido à do artigo 118, que prevê: "Os acordos de acionistas, sobre a compra e venda de suas ações, preferência para adquiri-las, exercício do direito a voto, ou do poder de controle deverão ser observados pela companhia quando arquivados na sua sede". Em contrapartida, assim dispõe o art. 116 caput, ao subjetivar o controlador: "Entende-se por acionista controlador a pessoa, natural ou jurídica, ou o grupo de pessoas vinculadas por acordo de voto, ou sob controle comum (...)”. COMPARATO. Fábio Konder; FILHO, Calixto Salomão. Op. cit., p. 63.

${ }^{96}$ BERLE, Adolf A.; MEANS, Gardiner C., Op. cit., p. 69.

${ }^{97}$ Fábio Konder Comparato critica a categoria de controle exercido através de expedientes legais proposta por Adolf Berle e Gardiner Means, limitando-se às outras quatro categorias delineadas pelos autores como espécies de controle interno na sociedade anônima e que integram a classificação proposta pelo autor. Dentre os exemplos apresentados por Adolf Berle e Gardiner Means e que, segundo os autores, integram a categoria de controle exercido através de expedientes legais, para Fábio Konder Comparato, somente o voting trust possui características que lhe são peculiares, razão por que justifica-se a sua classificação em categoria própria como modalidade de controle interno: "O trustee não pode ser assimilado a um proprietário (owner) e, nesse sentido, exerce o controle sem propriedade, mas, fundado, de qualquer modo, em direito próprio". COMPARATO, Fábio Konder; FILHO, Calixto Salomão. Op. cit., p. 64.
} 
bloco, mesmo sem que se disponha da parcela majoritária do capital social votante, tendo em vista a possibilidade do controlador minoritário indicar a maior parte dos membros da diretoria da sociedade anônima:

"In general, their control rests upon their ability to attract from scattered owners proxies sufficient when combined with their substantial minority interest to control a majority of the votes at the annual elections. Conversely, this means that no other stockholding is sufficiently large to act as a nucleus around which to gather a majority of the votes" $"$.

A legislação brasileira não prevê explicitamente a figura do controle minoritário, o que pode induzir, diante da interpretação gramatical do caput do art. 129, da Lei $\mathrm{n}^{\mathrm{o}}$ 6.404/76, à conclusão de que o mesmo não é reconhecido no ordenamento brasileiro. O artigo 129 da Lei das Sociedades por Ações, que trata sobre o quorum de aprovação das deliberações da assembléia geral, dispõe o seguinte: "As deliberações da assembléia geral, ressalvadas as exceções previstas em lei, serão tomadas por maioria absoluta de votos, não se computando os votos em branco" 99 .

No entanto, alerta Calixto Salomão Filho:

"O que o dispositivo pretende é apenas estabelecer uma regra procedimental para a Assembléia, prevendo que, tratando-se de Assembléia Geral, deverá votar favoravelmente à maioria dos presentes. A maioria ausente não é uma maioria, como deixam claros os art. 125,135 e 136 da mesma lei" ${ }^{\prime 100}$.

Especificamente sobre o que entende ser a melhor interpretação do enunciado normativo do artigo 136 da Lei societária, o autor prossegue:

"[o artigo 136 da Lei $\mathrm{n}^{0}$ 6.404/76] ao prever a obrigatoriedade dos acionistas com direito a voto para as deliberações nele enumeradas, deixa claro, a contrario sensu, que as

\footnotetext{
98 BERLE. Adolf. A.; MEANS, Gardiner C.. Op. cit., p. 75. "Geralmente, o seu controle [do controlador minoritário] reside na capacidade de obter de acionistas dispersos procurações suficientes que, quando somadas à sua parcela minoritária do capital social, lhe permitam controlar a maioria dos votos nas eleições anuais. Por outro lado, isso significa que nenhum outro bloco de ações é suficientemente representativo para agir como um núcleo capaz de obter a maioria dos votos nas deliberações sociais" Tradução livre.

${ }_{99}$ COMPARATO. Fábio Konder; FILHO, Calixto Salomão. Op. cit., p. 68/69.

${ }^{100}$ Ibid. p. 68/69.
} 
deliberações que ali não estejam enumeradas poderão ser aprovadas por acionistas representando a minoria do capital com direito a voto" ${ }^{\prime 101}$.

Da mesma forma, Fábio Konder Comparato depreende, da leitura sistemática dos dispositivos que tratam da estrutura de convocação e da deliberação da assembléia geral previstas na Lei $n^{0}$ 6.404/76, que, à luz da existência factual do controle minoritário, é possível tê-lo reconhecido sob o direito, a fim de que seja aplicada ao controlador a disciplina correspondente à sua posição na sociedade anônima ${ }^{102}$ :

"A existência de um controle minoritário está implicitamente reconhecida na lei, ao fixar as regras de quorum e maioria no funcionamento da assembléia geral. A norma geral é que a reunião se instala, em primeira convocação, com a presença de acionistas que representem no mínimo um quarto do capital social com direito a voto - que normalmente pode constituir apenas metade do capital social (Lei 6.404, artigo $15 \S 2^{\circ}$ ), salvo exceções e, em segunda convocação, com qualquer número (artigo 125). (...) Teoricamente, portanto, um só acionista, detentor de uma única ação, pode constituir a assembléia. A hipótese, aliás, nada tem de irreal; ela ocorreu efetivamente na França, e foi reconhecida como legal pelo Judiciário" ${ }^{\prime 103}$.

$\mathrm{O}$ autor destaca que, dentre os dois requisitos legais enunciados no artigo 116 da Lei $n^{\circ} 6.404 / 76^{104}$, aparentemente previstos para a constatação de ambas as modalidades de controle interno à companhia, majoritário ou não

\footnotetext{
${ }^{101}$ Ibid. p. 69.

${ }^{102}$ Diferentemente do sistema jurídico norte-americano, em que se admite a presunção juris tantum de existência de controle na sociedade anônima, no ordenamento brasileiro, o reconhecimento do controle minoritário prescinde de sua constatação, ressalvado o regime previsto por meio do Regulamento do Novo Mercado que permote a presunção relativa para reconhecimento do controlador, conforme se discute a seguir. Nos Estados Unidos, o Investment Company Act de 1940 dispõe que: "Any person who owns beneficially, either directly or through one or more controlled companies, more than 25 per centum of the voting securities of a company shall be presumed to control such company. Any person who does not so own more than 25 per centum of the voting securities of any company shall be presumed not to control such company" Ap. Ibid. p. 66. "Qualquer pessoa que tenha em seu benefício, diretamente ou através de uma ou mais companhias controladas, mais de $25 \%$ do capital votante da companhia é presumidamente o seu controlador. Assim, qualquer pessoa que não seja titular de $25 \%$ do capital votante da companhia não se enquadra presumidamente como controlador da companhia" Tradução livre.

103 Assim decidiu a Corte de Apelação de Paris, em 9.7.1935, Acórdão publicado em Dalloz Hebdomadaire, 1935. Ap. COMPARATO. Fábio Konder; FILHO, Calixto Salomão. Op. cit., p. 65.

${ }^{104} \mathrm{O}$ artigo 116, da Lei $\mathrm{n}^{\mathrm{0}}$ 6.404/76, assim dispõe: "Entende-se por acionista controlador a pessoa, natural ou jurídica, ou o grupo de pessoas vinculadas por acordo de voto, ou sob controle comum, que: a) é titular de direitos de sócio que lhe assegurem, de modo permanente, a maioria dos votos nas deliberações da assembléia geral e o poder de eleger a maioria dos administradores da companhia; e b) usa efetivamente seu poder para dirigir as atividades sociais e orientar o funcionamento dos órgãos da companhia".
} 
ao capital social votante, quais sejam: a existência de direitos de acionista que assegurem, de modo permanente, a maioria de votos na assembléia geral; e o uso efetivo do poder para a condução das atividades sociais ${ }^{105}$, o segundo somente seria exigível nos casos de configuração do controle minoritário. Conforme explica Calixto Salomão Filho:

"Apesar de o primeiro requisito aparentemente indicar no sentido da exigência de controle majoritário (i.e. o que derivaria do termo permanente), o segundo claramente é aplicável só a casos de controle minoritário. Em casos de controle majoritário, é irrelevante o uso efetivo do poder: o acionista terá status de controlador e as responsabilidades dele decorrentes, seja por ação ou por omissão" ${ }^{106}$.

Por essas razões e de acordo com a concepção do autor, o controle em ambas as formas, majoritária e minoritária, é reconhecido sob o ordenamento vigente, consideradas as particularidades que a cada modalidade correspondem e, em especial, a conseqüente disciplina legal que lhes é aplicável. No entanto, conforme atenta Calixto Salomão Filho, o reconhecimento do controle minoritário no ordenamento brasileiro para fins de aplicação da disciplina correspondente ao controle ao seu titular tem alcance limitado. Embora defenda a aplicação ampla do regime de responsabilidade previsto no artigo 117 da lei societária ao controlador interno ao capital votante da companhia, o autor entende inaplicável a exigência de realização de oferta pública de aquisição decorrente da alienação do controle da sociedade anônima, prevista no artigo 254-A, da Lei n ${ }^{0}$ 6.404/76. Aqui, sustenta Calixto Salomão Filho, prescinde-se da estabilidade da posição exercida pelo controlador, a fim de que se configure a alienação do controle como tal. Não se justifica, assim, obrigar o adquirente, nos casos de alienação

\footnotetext{
${ }^{105}$ Pelas razões que se discute no capítulo 4 deste estudo, o entendimento majoritário sobre o requisito de exercício efetivo do controle social na condução das atividades da sociedade anônima previsto na segunda parte do art. 116 da Lei $n^{\circ}$ 6.404/76 somente é exigível para a aplicação da disciplina correspondente ao exercício do controle social e não se confunde com a obrigatoriedade ao adquirente de realizar oferta pública diante da alienação da posição de controlador prevista no art. 254-A da lei societária, independentemente de seu exercício.

${ }^{106}$ COMPARATO, Fábio Konder; FILHO, Calixto Salomão. Op. cit., p. 69.
} 
de 'controle minoritário', à realização de oferta pública de aquisição das demais ações nos termos do artigo 254-A, da Lei n ${ }^{0} 6.404 / 76^{107}$. A discussão sobre a configuração da alienação do controle acionário no direito brasileiro é realizada, à luz de sua regulação e dos precedentes da Comissão de Valores Mobiliários - CVM, no final do quinto e último capítulo deste estudo.

No Regulamento da Listagem do Novo Mercado da Bovespa, admitido o caráter atípico do controle social e diante de suas tantas possíveis dimensões, optou-se por se tratar o 'controle da companhia' de 'controle efetivo' - condição imprescindível à aplicação da disciplina do controle ao seu titular. Isso, independentemente de sua qualificação como majoritário ou minoritário e, no caso das companhias listadas no Novo Mercado da Bovespa, inclusive no que tange à obrigatoriedade de realização de oferta pública nos casos de alienação da posição de controle efetivo por seu titular ${ }^{108}$. Opção regulamentar adotada como alternativa a se deixar o reconhecimento e a disciplina aplicável ao controle minoritário da sociedade anônima sob a penumbra das normas genericamente previstas ao controle, assim como o fez o legislador em sua regulação prevista na Lei $n^{\circ} 6.404 / 76$.

O benefício regulamentar que a utilização do conceito de 'controle efetivo', destaca Fábio Konder Comparato, reside, ainda, na restrição às possibilidades de escaladas societárias que permitam a aquisição do controle minoritário, sem que, em contrapartida, seja atribuída ao adquirente a

\footnotetext{
${ }^{107}$ COMPARATO, Fábio Konder; FILHO, Calixto Salomão. Op. cit., p. 70/71.

${ }^{108}$ O Regulamento de Listagem do Novo Mercado prevê, em sua seção II, a seguinte definição de 'poder de controle': ““'Poder de Controle” significa o poder efetivamente utilizado de dirigir as atividades sociais e orientar o funcionamento dos órgãos da Companhia, de forma direta ou indireta, de fato ou de direito. Há presunção relativa de titularidade do controle em relação à pessoa ou ao grupo de pessoas vinculado por acordo de acionistas ou sob controle comum ("grupo de controle") que seja itular de ações que lhe tenham assegurado a maioria absoluta dos votos dos acionistas presentes nas três últimas assembléias gerais da Companhia, ainda que não seja titular das ações que lhe assegurem a maioria absoluta do capital votante".

Disponível em <http://www.bovespa.com.br/pdf/RegulamentoNMercado.pdf>. Acesso em 21 ago. 2008.
} 
obrigação de realizar a oferta pública de aquisição das demais ações da sociedade anônima com direito de voto, que não as já adquiridas para a obtenção do controle dito 'efetivo'. Justifica-se esta opção regulamentar pelo alcance da posição de controlador efetivo da sociedade-alvo pelo adquirente, mesmo sem que tenha ocorrido a alienação de controle por seu eventual titular $^{109}$.

A quinta e última espécie de controle classificada por Adolf Berle e Gardiner Means refere-se ao que os autores denominam management control $^{110}$. O controle gerencial ocorre quando, tamanho o grau de dispersão acionária na sociedade anônima, que nenhum acionista, em grupo ou individualmente, é capaz de exercer o poder de decidir sobre os negócios sociais:

"Management control" is a phrase meaning merely that no large concentrated stockholding exists which maintains a close working relationship with the management or is capable of challenging it, so that the board of directors may regularly expect a majority, composed of small and scattered holdings, to follow their lead"111.

Em sua modalidade gerencial ou administrativa, são os membros da administração da sociedade anônima que exercem o controle de fato da companhia. Richard Posner adota especificamente esse conceito de 'management control', ao subjetivar a figura do controlador: "The control of the firm resides in a management group that gives order to the employees who buy the firm's inputs and makes and sells its output. The management group

\footnotetext{
${ }^{109}$ Ibid., p. 70/71. No quinto e último capítulo deste estudo, são analisadas as diferentes disciplinas previstas no ordenamento jurídico brasileiro para as hipóteses de oferta pública obrigatória, decorrente da alienação do controle, e a realizada voluntariamente, como instrumento para a obtenção da aquisição do controle na sociedade anônima, respectivamente previstas nos artigos 254-A e 257, da Lei $\mathrm{n}^{\mathrm{o}}$ 6.404/76, e reguladas pela Instrução CVM no 361 , de 5 de março de 2002.

110 BERLE, Adolf. A.; MEANS, Gardiner C.. Op. cit., p. 78. "A expressão 'controle gerencial' significa que nenhum bloco de ações do capital social tem relação íntima com a administração da companhia ou é capaz de afrontá-la em suas decisões, de modo que os diretores podem esperar que a maioria dos acionistas dispersos da companhia seguirá as suas decisões sociais” Tradução Livre.

111 BERLE, Adolf A.. Power. Op. cit., p. 73. "O controle da sociedade reside no grupo de administradores integrado por pessoas com experiência no objeto social da companhia e nele envolvido integral e diariamente" Tradução livre.
} 
consists of people who are experienced in the business and involved in it on a full-time, day-to-day basis"112. De acordo com os fins deste ensaio, a compreensão dessa espécie de controle é particularmente importante ao estudo dos pressupostos de utilização de estratégias de defesa a uma oferta hostil de aquisição por parte dos administradores da sociedade anônima, realizado nos itens 3.4 e 4.4 deste trabalho.

Classificadas as modalidades de controle interno, passa-se à discussão sobre a possibilidade de o 'controle efetivo' da sociedade anônima ser, por um agente inicialmente estranho à companhia, exercido.

\subsection{Bayne vis-à-vis Comparato: o fenômeno do controle externo na sociedade anônima}

"There is no apparent desire, and not much reason, to try to break up great economic organizations. When they do not perform satisfactorily, the most obvious remedy at present is not to change the system but to change the managers" "113 (Berle, 1959).

A filosofia do poder de controle desenvolvida por David Cowan Bayne fundamenta-se na localização do office da sociedade anônima, como a origem real do controle na companhia e que, necessariamente, se situa dentro da sociedade controlada ${ }^{114}$. De acordo com o autor:

"Around the office of the contrôleur the major corporate-control considerations revolve. To the office the custody of the corporation has been entrusted. In the office the relation inheres. Upon the office the fiduciary duties rest. To the office all the rights belong. From the office, therefore, all corporate-control activities arise" ${ }^{115}$.

\footnotetext{
112 POSNER, Richard A.. Op. cit., p. 451. "O controle da companhia reside no grupo de administradores que dá ordens aos empregados da companhia e que, em seu lugar, compram os insumos da companhia e produz e vende os seus produtos. O grupo de administração é integrado por pessoas com experiência na condução dos negócios sociais e envolvidos diariamente em sua atuação" Tradução livre.

${ }^{113}$ BERLE, Adolf. Op. cit., p. 87.

${ }^{114}$ BAYNE, David Cowan. Op. cit., p. 111.

${ }^{115}$ Ibid. p. 111. "Ao redor do office do controlador, as principais decisões de controle da companhia são tomadas. Ao office, a custódia da companhia é confiada. Nele, todas as relações da companhia são investidas. No office, o dever fiduciário existe. Ao office, todos os direitos pertencem. Assim, do office, todas as atividades relacionadas ao controle da companhia surgem” Tradução livre.
} 
Nessa perspectiva, o exercício de controle é uma relação oficial ou, mais especificamente, "a fiduciary relationship to the corporation"116. David Cowan Bayne compreende o controle na sociedade anônima como uma relação entre o controlador e a companhia que, por conseqüência, corresponde a direitos conferidos aos acionistas da companhia controlada. Direitos esses relacionados ao modo de exercício do controle na sociedade anônima por seu titular:

"The corporate control is a relation of total custody, affected by the appropriation of the corporate entity, subsisting between the office of the contrôleur and the corporation, giving rise to a complexus of duties and a corresponding complexus of rights directed to the benefit of the shareholders" $" 17$.

Da teoria desenvolvida por David Cowan Bayne, destacam-se duas características fundamentais à compreensão do autor sobre o fenômeno do controle na sociedade anônima: a sua necessária existência, como feixe de poder na companhia, e o fato de que o seu office - que na teoria proposta pelo autor se identifica ao controle - localiza-se necessária e internamente à sociedade controlada:

"The office of the contrôleur rightfully belongs inside the legal entity. In the present state of the law, moreover, the office of the contrôleur is not even classified with the extracorporate parties, creditors, labor, consumer, government. It has been left by the law in a never-never land, somewhere it is true, but the courts have never specified exactly where" ${ }^{\text {118. }}$.

Por essa razão, a construção conceitual da figura do controle externo, sustenta o autor, ao contrário de se mostrar oportuna à observação do fenômeno do controle na sociedade anônima, decorreria da incompreensão de

\footnotetext{
${ }^{116}$ Ibid. p. 99. “[o exercício do controle] é uma relação fiduciária frente à companhia” Tradução livre.

${ }^{117}$ Ibid. p. 99. "o controle da sociedade anônima é uma relação de total custodia, realizada mediante a apropriação da companhia, existente entre o office do controlador e a companhia, dando origem a uma gama de deveres ao controlador e, conseqüentemente, a direitos que dos deveres correspondem em benefício dos acionistas" Tradução livre.

118 Ibid. p. 112. "O office do controlador necessariamente pertence à dimensão interna da companhia. Além disso, no estágio atual do direito, o office do controlador não é sequer classificado a agentes externos à sociedade, tais como credores, empregados, consumidores ou o próprio governo. A localização do controle foi deixada pelo direito como lacuna, em alguma local específico, mas que as cortes nunca definiram aonde especificamente" Tradução livre.
} 
sua natureza - como relação necessária e oficial entre o controlador e a sociedade, da qual decorreriam direitos e obrigações.

Na doutrina brasileira, Nelson Eizirik não observa o reconhecimento do controle externo ou gerencial sob o ordenamento vigente para fins de aplicação da disciplina correspondente ao controle. Para tanto, baseia-se na interpretação gramatical do artigo 116 , da Lei $n^{0}$ 6.404/76, que conceitua a figura do controlador. Explica o autor:

"Inicialmente, deve ser observado que a Lei das S/A., em seu art. 116, ao conceituar o acionista controlador, admitie apenas a forma interna de dominação da companhia, uma vez que impõe como requisito para a sua caracterização a titularidade dos direitos de sócio. Daí decorre que foram excluídas, tanto do âmbito do art. 116, como do art. 254-A, as hipóteses de controle externo ou gerencial" ${ }^{\prime 19}$.

Às posições de David Cowan Bayne e de Nelson Eirizik contrapõe-se a de Fábio Konder Comparato. Assim o autor fundamenta a realidade do controle externo: "Pode ocorrer que o verdadeiro titular dos poderes decisórios não seja acionista, curvando-se, então, a assembléia geral a uma soberania externa" ${ }^{120}$. Do entendimento de que o exercício do controle possa ser determinado por um agente externo à sociedade, através da capacidade de se lhe determinar o direcionamento de seus negócios sociais, deriva a qualificação como externa do controle na sociedade anônima. Isso, seja através do poder de aprovar determinadas deliberações ${ }^{121}$, ou por meio da barganha diante da qual a sociedade possa vir a se curvar: como conseqüência da manifestação do poder econômico de um agente externo ${ }^{122}$.

Por essas razões, entende-se que, em acréscimo às modalidades de controle interno propostas por Adolf Berle e Gardiner Means e apresentadas no item anterior desta pesquisa, é possível classificar o controle

\footnotetext{
${ }^{119}$ EIZIRIK, Nelson. Temas de Direito Societário. Rio de Janeiro: Editora Renovar, 2005. p. 235.

${ }^{120}$ COMPARATO, Fábio Konder; FILHO, Calixto Salomão. Op. cit., p. 52.

${ }^{121}$ Ibid. p. 39.

${ }^{122}$ BERLE, Adolf A.. Op. cit., p. 82.
} 
espacialmente, como mais tarde em sua produção admitiu o próprio Adolf Berle $^{123}$, e de modo a refletir a posição interna ou externa de seu titular em relação à sociedade controlada. De acordo com essa concepção geográfica de ambas as formas de controle, 'interno' e ‘externo', Fábio Konder Comparato propõe definir o primeiro como aquele em que: "o titular do controle atua no interior da sociedade ( $a b$ intus), lançando mão dos mecanismos de poder próprios da estrutura societária, notadamente a deliberação em assembléia" ${ }^{124}$, e controle externo o que se localize $a b$ extra à sociedade, ou aquele que: "pertence a uma ou mais pessoas físicas ou jurídicas que não compõem quaisquer órgãos da sociedade, mas agem de fora" $" 125$.

A compreensão sobre a atipicidade do fenômeno do controle na sociedade anônima, também com relação à sua localização interna ou externa à companhia, levou à positivação de enunciados normativos substancialmente abertos, que visam a permitir a configuração do controle de acordo com as suas peculiaridades no caso concreto. No direito norte-americano, a Regulation 12B, da Securities and Exchange Comission define o controle amplamente, de modo a também contemplar a sua acepção externa: "the possession direct or indirect, of the power to direct or cause the direction of the management and policies of a person, whether through the ownership of voting securities, by contract, or otherwise" ${ }^{\text {126. }}$.

De todo modo, independentemente de se adotar ou não a classificação espacial do controle em interno ou externo e conforme se discutiu no capítulo 1 desse ensaio, sustenta Fábio Konder Comparato, ao final: “a definição de

\footnotetext{
${ }^{123}$ Ibid. p. 82.

${ }^{124}$ COMPARATO, Fábio Konder; FILHO, Calixto Salomão. Op. cit., p. 48.

${ }^{125}$ Ibid. p. 48.

126 Apud. COMPARATO, Fábio Konder; FILHO, Calixto Salomão. Op. cit., p. 45. "a titularidade direta ou indireta do poder de conduzir ou de direcionar a administração e as diretrizes de uma pessoa, seja através da propriedade do capital votante, por contrato ou por qualquer outro modo" Tradução livre.
} 
poder de comando é sempre feita em função da assembléia geral, que constitui a última instância societária" ${ }^{\prime 27}$. E a respeito do conceito de controle externo, conclui: "Eis por que Ascarelli o definiu, sinteticamente, como "a possibilidade de uma ou mais pessoas imporem a sua decisão à assembléia da sociedade $", 128$

Excetuada a primeira modalidade de controle classificada, ou o controle exercido através da total ou quase integral titularidade acionária, em que praticamente o domínio decorrente do controle se confunde com o relativo à titularidade da propriedade acionaria e, sobretudo, diante da admissão de que o titular do exercício do controle na sociedade anônima possa lhe ser externo, evidencia-se a fragilidade do acionista frente ao controlador. Ilustrativamente, isso, seja do minoritário e do acionista preferencial sem direito de voto, nos casos de controle minoritário ou majoritário; ou de todo o corpo acionário, diante de seu exercício gerencial ou externo. Assim, entende-se a figura do controlador, mesmo quando externa à sociedade anônima, a ela inafastável: como feixe de competências relacionadas ao exercício de funções imprescindíveis à condução dos negócios sociais e, de assim, ser a real origem do poder na companhia ${ }^{129}$.

Privilegiando-se o controle como relação jurídica decorrente de sua constatação fática, propõe-se reler as relações reguladas através do direito societário, à luz do instrumental teórico propiciado pela teoria econômica. Cruzam-se o conceito e a natureza dos problemas de agência e as relações entre os participantes da sociedade anônima. Para tanto, são adotados os fundamentos metodológicos da corrente teórica a que Reinier Kraakman e Paul Davies se referem como 'análise funcional do direito'. Antes, no entanto,

\footnotetext{
${ }^{127}$ Ibid., p. 39.

${ }^{128}$ ASCARELLI, Túlio. Problemi Giuridici, Milão, 1959, t. I, p. 267, nota 23. Ap., COMPARATO, Fábio Konder; FILHO, Calixto Salomão. Op. cit., p. 39.

${ }^{129}$ COMPARATO, Fábio Konder; FILHO, Calixto Salomão. Op. cit., p. 142.
} 
passa-se ao estudo dos pressupostos históricos que justificam a regulação da sociedade anônima. 


\title{
Capítulo 3 - Uma proposta de releitura funcional do direito societário: tutela e objetivos
}

\author{
"The modern corporation [must] serve not only the owners \\ or the control but all society" $"$ (Berle e Means, 1932).
}

\subsection{O desenvolvimento do direito societário contemporâneo e a tutela da informação no mercado de capitais: pressupostos}

\begin{abstract}
"What relationship is there, then, between blue-sky regulation and utility securities? The essential feature of blue-sky legislation is the intent to prevent fraud and unfair practices in the sale of securities. It is not the function of such legislation to protect the purchaser of securities against such danger of loss as may be inherent in the security which he buys. Neither is such legislation designed to prevent the purchaser from speculating if he desires to do so. It is designed to assure, (...) that the buyer of securities is not misled as to the real nature of what he buys, that where he is buying speculative securities he be sufficiently advised of that fact, and that he have in return for the risk which he assumes, a fair chance for speculative profit" ${ }^{\prime 131}$ (George Matthews, 1929).
\end{abstract}

Desde o final do século XVIII, quando ocorreu a desvinculação da concessão estatal à constituição das 'societés anonymes' ${ }^{132}$, adquiriu destaque, dentre os modelos societários existentes, a sociedade por ações, e, mais especificamente, a sociedade anônima ${ }^{133}$.

\footnotetext{
${ }^{130}$ BERLE. Adolf. A.; MEANS, Gardiner C.. Op. cit., p. 376. Ap. BAYNE, David Cowan. Op. cit., p. 98. "A companhia moderna deve servir não somente aos seus acionistas, mas sim a toda a sociedade." Tradução livre.

131 MATTHEW, George C.. Blue-Sky Regulation and Public Utility Securities, Madison: Statistical and Securities Department, 1929. p. 1/2. Disponível em <http://www.sec.gov/news/speech/1933/092627-2829mathews.pdf>. Acesso em 19 jul. 2008. "Qual, então, é a relação entre a regulação 'blue-sky' e os valores mobiliários negociados no mercado? O elemento essencial na regulação 'blue-sky' é o objetivo de prevenir a realização de fraudes de práticas não-equiitativas na venda de valores mobiliários. Não é o objetivo desta legislação proteger o adquirente de títulos no mercado de capitais contra o risco de perda que pode ser inerente ao valor que ele adquire. Tampouco é o objetivo desta legislação proibir o investidor de especular, caso ele assim deseja fazê-lo. [A regulação 'blue.sky'] é sim concebida (...) para que o adquirente de valores mobiliários não seja induzido a erro com relação à real natureza do que compra, e que nesta aquisição, tenha sido suficientemente alertado sobre os riscos assumidos em contrapartida à sua expectativa de obter lucro" Tradução livre.

${ }^{132}$ FILHO, Alfredo Lamy; PEDREIRA, José Luiz Bulhões. Op. cit., p. 51.

133 Como instrumento concebido para a captação de recursos e o desenvolvimento da atividade econômica organizada, destaca-se a sociedade anônima dita aberta, nos termos do art. $4^{\circ}$, da Lei ${ }^{\circ}$ 6.404/76. Com efeito, é importante notar que a Lei $\mathrm{n}^{\circ} 6.404 / 76$, que no ordenamento jurídico
} 
A razão para a preeminência da companhia com relação aos demais tipos societários fundou-se na conveniência que a sua constituição proporcionava. Diferentemente de outros modelos existentes à época da concepção da sociedade anônima, a companhia facultava aos seus participantes o exercício concomitante de duas prerrogativas principais: a delimitação de suas respectivas responsabilidades à parcela do capital social por cada subscrito e a delegação da gestão da sociedade anônima para realização da empresa a quem julgassem mais apto. Mitigava-se, assim, o risco incorrido por empreendedores na consecução do objeto que se propunham realizar, bem como, simultaneamente, possibilitava-se que fossem apurados mais vultosos recursos para o desenvolvimento da atividade econômica organizada ${ }^{134}$.

Ao longo da história, a popularização da sociedade anônima como instrumento concebido para a captação de recursos à realização da empresa ${ }^{135}$ resultaria no aumento do número de participantes do mercado de capitais, bem como evidenciou inúmeras dificuldades relacionadas às dimensões de seu exercício. Desde a forma de gestão do capital apurado, até os distintos níveis de informação disponibilizados ao público-investidor, reguladores e participantes do mercado de capitais buscaram adequar as faculdades atribuídas aos integrantes da sociedade anônima aos anseios sociais sobre à forma de seu funcionamento. Nessa perspectiva, foram delineados princípios e

\footnotetext{
brasileiro, regula as sociedades por ações, não tem como objeto somente estruturar a sociedade anônima em suas modalidades aberta e fechada. A Lei das Sociedades por Ações regula, em seu artigo 280 e seguintes, a sociedade em comandita por ações que, pelo regime de responsabilidade prescrito aos sócios-diretores ou gerentes das comanditas por ações e presente em seus artigios 282 e 282 da lei societária não alcançou popularidade como instrumento para o desenvolvimento da atividade econômica organizada. FILHO, Alfredo Lamy; PEDREIRA, José Luiz Bulhões, Op. cit., p. 19.

${ }^{134}$ REQUIÃO, Rubens. Direito Comercial. $1^{\circ}$ vol. São Paulo: Saraiva, 2005. p. 373/374.

${ }^{135}$ A popularidade historicamente adquirida pela sociedade anônima justifica-se pelas faculdades que a sua constituição propicia aos seus participantes. Assim aponta Richard Posner a respeito da natureza econômica dos tipos societários: "The firm is a method of organizing production; the corporation is a method, like a bond indenture, for attracting capital into the firm". POSNER, Richard A., Op. cit., p. 451. "A empresa é um método de organização da produção; a companhia um instrumento, como uma debênture, de capitalização da empresa” Tradução livre.
} 
standards que deveriam reger a atuação dos participantes do mercado: entendido como o local em que, dentre outros, são transacionados os valores de emissão das sociedades anônimas ${ }^{136}$.

Compreendido, ainda, como produto de múltiplas relações em que seus agentes buscam se beneficiar através da realização de trocas que lhes sejam favoráveis ${ }^{137}$, o mercado opera de modo que, em síntese, é o comportamento de seus participantes que determina o preço dos valores nele negociados. Conforme se discute a seguir, é a elementar lei da oferta e da demanda que melhor explica os preços dos valores mobiliários transacionados no mercado e, assim, da sociedade anônima:

"The extended conflict among selfish people produces prices that allocate resources to their best uses. This is an old story and Adam Smith's The Wealth of Nations (1776) remains the best exposition" $"$.

Com efeito, facultar a captação da poupança popular para o desenvolvimento da atividade econômica organizada mostrou-se um instrumento em si insuficiente à positiva aferição social dos resultados que da sociedade anônima adviriam. Ao contrário, as diversas disfunções que, ao longo da história, se evidenciaram no funcionamento do mercado de capitais

\footnotetext{
${ }^{136}$ De acordo com os fins do presente estudo, mesmo reconhecida a maior extensão do conceito de valores mobiliários a que se refere o artigo $2^{\circ}$, da Lei $n^{\circ} 6.385 / 76$, que regula a competência prevista à Comissão de Valores Mobiliários - CVM, privilegia-se, aqui, a discussão sobre o exercício da sociedade anônima dita de capital aberto e dos valores por ela negociados. Alfredo Lamy Filho e José Luiz Bulhões Pedreira explicam que a diferença elementar entre as companhias 'abertas' e 'fechadas' e que legitima a mais estrita regulação e fiscalização da administração e das emissões das companhias registradas reside no acesso à poupança pública que somente as mesmas possuem para o financiamento de suas respectivas atividades. FILHO, Alfredo Lamy; PEDREIRA, José Luiz Bulhões. Op. cit., p. 83.

${ }^{137}$ Frank Easterbrook e Daniel Fischel definem 'mercado' como: "Economic interactions among people dealing as strangers and seeking personal advantage". EASTERBROOK, Frank H.; FISCHEL, Daniel R.. Op. cit., p. 8. "[Mercados são] interações econômicas realizadas impessoalmente por diversos agentes que buscam se beneficiar através das trocas realizadas" Tradução livre.

${ }^{138}$ Ibid. p. 8. "O conflito entre agentes que atuam em busca de seu melhor interesse produz os preços que, por consequiência, alocam os recursos conforme o seu melhor uso. Essa constatação é antiga e a obra 'A Riqueza das Nações' de Adam Smith (1976) permanece até hoje como a melhor exposição" Tradução livre.
} 
justificavam-no como objeto de regulação naquilo em que fosse imperfeito ${ }^{139}$. Em especial, percebeu-se que regulamentar o relacionamento dos participantes da sociedade anônima, a fim de se disponibilizar níveis de informação a todos comuns, era uma condição imprescindível ao melhor funcionamento do mercado de valores mobiliários. Nesse movimento regulatório, dentre os tantos objetos em que se fundou a regulação da sociedade anônima e dos mercados, destacou-se a tutela da informação no mercado de valores mobiliários $^{140}$.

Podem-se ressaltar duas principais dimensões que a informação como 'valor' apresenta no escopo do direito societário. Primeiro, percebeu-se a 'informação' como uma ferramenta imprescindível à sustentabilidade da captação realizada pela companhia e, por consequiência, do bom funcionamento dos mercados. Ao final, a ciência da real situação negocialfinanceira da sociedade anônima deve, sob um ponto de vista racional, ser compreendida como imprescindível à realização de investimentos. Num segundo aspecto e à luz da assertiva microeconômica de Adam Smith sobre a preponderância das interações entre compradores e vendedores na formulação dos preços dos valores negociados no mercado, a correta precificação da sociedade anônima prescinde das reações dos agentes econômicos às informações divulgadas pela companhia e, assim, de sua adequada prestação.

Dessa forma, compreendeu-se que a realização do princípio do 'full disclosure' no direito societário possibilitaria que as informações disponibilizadas pelos administradores da sociedade anônima se propagassem no mercado, de modo que os preços dos títulos nele negociados refletissem o

\footnotetext{
${ }^{139}$ FILHO, Alfredo Lamy; PEDREIRA, José Luiz Bulhões. Op. cit., p. 83.

140 Marcelo Fernandez Trindade destaca a importância da tutela da informação como instrumento regulatório do exercício da sociedade anônima e do mercado de capitais; "A informação é o principal bem jurídico tutelado pela intervenção estatal no mercado de capitais, inclusive no mercado de valores mobiliários". TRINDADE, Marcelo Fernandez, O papel da C.V.M. no mercado de capitais no Brasil. S. Ed. p. 309.
} 
seu real valor. Conforme destacam Frank Easterbrook e Daniel Fischel e discutido no item 3.2 seguinte deste ensaio, esta mesma regra de precificação dos valores mobiliários pode ser aplicada tanto à estruturação do relacionamento entre os participantes da companhia, como ao modo de exercício do controle na sociedade anônima ${ }^{141}$.

Marcelo Fernandez Trindade destaca a importância de tutela da informação como instrumento para a tomada de decisão em investir:

"Com a disseminação da informação, segundo os padrões de qualidade e frequiência estabelecidos na regulamentação, presume-se que o investidor tomará a melhor decisão de investimento e que as frausdes serão evitadas. Tornou-se lugar comum citar a frase de Louis Brandeis, depois Ministro da Suprema Corte Americana, ao defender o full disclosure, ainda em 1914: "Sunlight is said to be the best of disinfectants;eletric light the most efficient policeman $" 142$.

Da realização do princípio de full disclosure nos sistemas jurídicos contemporâneos, subsume-se a aplicação do princípio da 'rational ignorance' à lógica do mercado de capitais. Concebido para o estudo genérico de modelos representativos e intrinsecamente relacionado à teoria da informação, o princípio da 'ignorância racional' e a sua adoção instrumental para o estudo da tutela da informação no direito societário refere-se à possibilidade conferida

\footnotetext{
${ }^{141}$ Explicam Frank Easterbrook e Daniel Fischel: "Managers of public corporations face a potent information market. Few markets are as efficient as capital markets are. Poor performance leads the markets to respond in ways that bring the costs home to the managers. First, investors (both informed and uninformed) will pay less for shares. The more investors believe that their dollars will be used by those in control of firms in ways inconsistent with maximizing the value of the firm, the less they will pay for shares. To minimize this rational fear, those in control have incentives to adopt governance mechanisms that limit their discretion to benefit at investors' expense". EASTERBROOK, Frank H.; FISCHEL, Daniel R.. Op. cit., p. 96. "Administradores de companhias abertas lidam com um mercado de informação expressivo. Poucos mercados são tão eficientes como os mercados de capitais. Desempenhos negativos levam os mercados a responder de forma a levar os custos incorridos aos administradores. Em primeiro lugar, investidores (informados ou não) pagarão menos pelas ações da companhia. Quanto mais investidores acreditem que o seu dinheiro será utilizado por aqueles que detenham o controle social de forma inconsistente com a maximização do valor da empresa, menos eles estarão dispostos a pagar pelas ações da companhia. A fim de minimizar este temor racional dos investidores, os controladores têm incentivos para adotar mecanismos de governança que limitarão a sua discrição em agir em seu próprio benefício ao custo dos investidores" Tradução livre.

${ }^{142}$ TRINDADE, Marcelo Fernandez, O papel da C.V.M. no mercado de capitais no Brasil. S. Ed. p. 309. "A luz do sol é tida como o melhor desinfetante; a luz elétrica o policial mais eficiente". Tradução livre.
} 
aos participantes do mercado de capitais de, individualmente, e por meio das informações amplamente disponíveis e de divulgação obrigatória pela sociedade anônima, definirem o nível informacional que desejam possuir ao tomar a decisão de investir. À luz da teoria econômica, o princípio da 'rational ignorance' pode ser entendido como:

"A principle of public choice theory is that it is rational for a voter to be ignorant about an issue unless that issue has a perceptible effect on voters' income. Rational ignorance is the decision not to acquire information because the cost of doing so exceeds the expected benefit" ${ }^{\text {143 }}$.

O dever imposto aos administradores da sociedade anônima de capital aberto em, publicamente, disponibilizar elevados níveis de informação prestados em conformidade com padrões prescritos pela autoridade regulamentar competente permite a realização da autonomia da vontade em que se baseia o princípio da 'rational ignorance' em sua fundação ${ }^{144}$. Cabe a cada participante do mercado, de acordo com o seu custo marginal respectivo à obtenção de informação e o retorno dela esperado, determinar o grau informacional 'ótimo', ou o seu nível respectivo em que benefícios e custos correspondentes à aquisição de informação se equalizem ${ }^{145}$. Deixa-se ao arbítrio dos agentes econômicos a decisão pela ciência do real valor dos títulos negociados no mercado ou a opção pela ignorância, conforme, individualmente, melhor lhes aprouver.

Com efeito, o exercício dos mercados e a realidade da captação realizada pela sociedade anônima mostraram-se distintos em muitos desses

\footnotetext{
${ }^{143}$ PARKIN, Michael. Microeconomics. $7^{\text {th }}$ Ed. New York: University of Western Ontario Pearson Addison Wesley, p. 364. "Um princípio da teoria da escolha pública é que é racional para um eleitor desconhecer determinado assunto, salvo se aquela questão tiver um efeito perceptível na receita do eleitor. A 'ignorância racional' do eleitor é a decisão de não obter a informação, justamente porque o seu custo de aquisição supera o benefício dela esperado" Tradução livre.

${ }^{144}$ Ibid. p. 364.

${ }^{145}$ Ibid. p. 364.
} 
$\operatorname{aspectos}^{146}$. Na inexistência de instrumentos que fossem além a tão-somente garantir o acesso a níveis de informação comuns a todos os agentes econômicos, percebia-se que potenciais pequenos investidores acabavam por não vir a participar do mercado de capitais. Em situações em que o custo individual para a obtenção da informação para tanto considerada como mínima se mostrasse elevado frente ao potencial retorno que investimentos de menor dimensão pudessem vir a apresentar, simplesmente, se excluía a participação do investidor comum no mercado de capitais.

Mais ainda, as barreiras de entrada existentes à participação no mercado de capitais referem-se, ainda, a desigualdades decorrentes de falhas no sistema educacional e às inúmeras áreas de saber distintas da formação econômica $^{147}$. A 'democratização' do mercado de capitais a que se referiram Alfredo Lamy Filho e José Bulhões Pedreira na concepção da Lei $\mathrm{n}^{\mathrm{o}}$ $6.404 / 76^{148}$ deve ser entendida amplamente. Desejável, assim, que o regulador atente para as limitações ao funcionamento ótimo da companhia e do

\footnotetext{
${ }^{146}$ Especificamente ao tratar do exercício do poder econômico e da desigualdade entre participantes do mercado, Fábio Konder Comparato complementa: "Ambas as idéias, da ação comunicativa e do déficit de conhecimento ou informacional, implicam e requerem o combate ao poder econômico. Um dos maiores empecilhos à transmissão de informações e á troca comunicativa é o poder econômico. Conseqüência direta é então o desequilíbrio das relações do ponto de vista econômico e então o desequilíbrio de distribuição de renda. A relação entre poder econômico concentrado e subdesenvolvimento é, nessa perspectiva, de implicação necessária”. COMPARATO, Fábio Konder; FILHO, Calixto Salomão. Op. cit., p. 21.

${ }^{147}$ A diferenciação das categorias de investidores é reconhecida sob a regulação vigente no mercado de capitais brasileiro. Como exemplo, no exercício de sua competência regulamentar, a CVM baixou a Instrução $n^{0} 394$, de 22 de julho de 2003, em que dispõe sobre a possibilidade de negociações privadas com valores mobiliários por parte dos fundos de investimento regulados pela autarquia e destinados, exclusivamente, a investidores qualificados. A razão à menor regulação imposta ao agente emissor diante da qualificação dos destinatários de sua oferta diz respeito, justamente, à maior expertise que se presume que determinados agentes econômicos possuem na realização de investimentos.

${ }^{148}$ A Exposição de Motivos n ${ }^{\circ} 196$, de 24 de junho de 1976, da Lei n ${ }^{\circ}$ 6.404/76, destaca a importância em se proteger os acionistas minoritários na regulação da sociedade anônima tanto pela tutela aos interesses privados relacionados à companhia, como forma de se permitir a sustentabilidade do crescimento econômico propiciado pela sociedade anônima: "A mobilização da poupança popular e o seu encaminhamento voluntário para o setor empresarial exigem, contudo, o estabelecimento de uma sistemática que assegure ao acionista minoritário o respeito a regras definidas e eqüitativas, as quais, sem imobilizar o empresário em suas iniciativas, ofereçam atrativos suficientes de segurança e rentabilidade". Disponível em <http://www.cvm.gov.br/port/atos/leis/6404_Exposicao.asp > Acesso em 3 Out. 2008.
} 
mercado, tais como a falhas na captação de recursos, a fim de se potencializar os resultados econômico-sociais alcançáveis através da interação entre os agentes no funcionamento do mercado. A ratio principal deste movimento sobre o qual se estruturou o direito societário contemporâneo foi proporcionar a estabilidade imprescindível ao adequado funcionamento dos mercados. A prescrição de padrões aos participantes do mercado e a físcalização de seu atendimento, ao final, a todos beneficiaria: às companhias ofertantes de valores mobiliários, pela possibilidade de, através de sua emissão, financiar suas respectivas atividades; ao público-investidor, pela garantia de níveis de proteção mínimos à realização de investimentos ${ }^{149}$; e à sociedade como um todo, pela elevação do bem-estar social decorrente da atividade econômica organizada desenvolvida pela companhia.

Nos Estados Unidos, foram muitos os atos normativos editados a fim de se delinear standards à conduta dos participantes do mercado de capitais. As denominadas blue sky laws do início do século $\mathrm{XX}^{150-151}$ consubstanciaram a

\footnotetext{
${ }^{149} \mathrm{Um}$ dos principais instrumentos relacionados à tutela da informação no mercado de capitais é a obrigatoriedade imposta aos administradores da sociedade anônima registrada de divulgar todo e qualquer fato relevante ao mercado, conforme determina a Lei $n^{\circ} 6.404 / 76$, em seu art. $157, \S 1^{\circ}$, alínea 'e', e regulada por meio da Instrução CVM no 358 , de 3 de janeiro de 2002, instituída pela autarquia com fundamento na sua competência regulamentar conferida pelo art. 21-A, da Lei 6.386/76. ${ }^{150}$ Kenneth Clarkson comenta três decisões da Suprema Corte norte-americana de 1917, em que se discutiu o fundamento sobre o real valor de títulos negociados no mercado. A partir do julgamento dos 'Hall cases', em menção a Hall vs. Geiger-Jones Co., 242 U.S. 539 (1917), a expressão "blue sky laws" tornou-se familiar com o significado que até hoje lhe é atribuído: "The phrase blue sky laws dates to a 1917 United States Supreme Court decision in which the Court declared that the purpose of such laws was to prevent "speculative schemes which have no more basis than so many feet of "blue sky"”. CLARKSON, Kenneth W.. Op. cit., p. 839. “A expressão 'blue sky laws' refere-se a uma decisão da Suprema Corte norte-americana de 1917, que declarou que o objetivo dessas leis era o de coibir "estratagemas especulativos que não tinham mais fundamento que "so many feet of "blue sky" "” Tradução livre.

${ }^{151}$ George C. Matthews expõe as razões em que fundaram as 'blue sky laws' ou a 'proteção do público-investidor: "Blue sky legislation is in a measure paternalistic but that paternalism is not intended to limit the individual in taking risks with his money. It protects him only to the extent that it interferes with the right of someone else to sell him securities which in themselves are fraudulent or unfair or to sell him any securities by fraudulent or unfair methods". MATTHEW, George C. Op. cit., p. 2. Disponível em <http://www.sec.gov/news/speech/1933/0926-27-2829mathews.pdf>. Acesso em 1 fev. 2008. “A legislação 'Blue Sky' é, em certa medida, paternalista, porém não no sentido de limitar a liberdade individual em assumir riscos com o seu próprio dinheiro na realização de investimentos, mas sim com a finalidade de protegê-la através da interferência no direito de um terceiro em vender
} 
vedação legal em se estabelecer esquemas especulativos, mediante a oferta de ações sem fundamento quanto ao seu real valor ${ }^{152}$. Outros marcos do sistema regulatório norte-americano que exerceram enorme influência sobre a positivação de diversos sistemas jurídicos, dentre os quais o brasileiro, foram o Securities Act e o Securities and Exchange Comission Act, respectivamente de 1933 e 1934. Superava-se a visão estrita sobre o bom funcionamento do mercado de capitais. Passava-se, então, à percepção de que a tutela proporcionável mediante a regulação do funcionamento da sociedade anônima era de interesse, não-somente restrito de seus diretos participantes, mas sim de toda a sociedade. Um instrumento elementar de política macroeconômica, pois diretamente relacionado ao desenvolvimento da atividade econômica organizada e também concebido com a finalidade de coibir crises econômicosociais, como a ocorrida nos Estados Unidos em $1929^{153}$.

A progressiva importância adquirida pela sociedade anônima e, mais especificamente, por aquela dita de capital aberto, levou à instituição, em diversos países, de entes específicos, cuja principal atribuição seria assegurar que os agentes participantes do mercado de capitais atendessem ao princípio do full disclosure realizado, especialmente, através da regulação da divulgação de informações pela sociedade anônima ${ }^{154-155}$. Na França, foi instituída por meio da Ordenação n ${ }^{0}$ 67.833, de 1967 a Comission des Operations de Bourse ${ }^{156}$; na Itália, a Lei $n^{0} 216$, de 1974, criou a Comissione Nazionale per le Società e la

valores mobiliários que, em si, são fraudulentos ou injustos, ou valendo-se de meios injustos ou fraudulentos" Tradução livre.

${ }^{152}$ FILHO, Alfredo Lamy; PEDREIRA, José Luiz Bulhões. Op. cit., p. 83.

153 DUBEUX, Júlio Ramalho. A Comissão de Valores Mobiliários e os principais instrumentos regulatórios do mercado de capitais brasileiro. Porto Alegre: Sérgio Antônio Fabris, 2006. p. 39.

${ }^{154}$ TRINDADE, Marcelo Fernandez, O papel da C.V.M. no mercado de capitais no Brasil. S. Ed. p. 307 e ss.

${ }^{155}$ LEÂES, L.G. Paes de Barros. Mercado de capitais e insider trading, São Paulo: Editora Revista dos Tribunais, 1982. p. 70 .

${ }^{156}$ FILHO, Alfredo Lamy; PEDREIRA, José Luiz Bulhões. Op. cit., p. 17. 
Borsa $^{157}$ e, no Brasil, a Lei $\mathrm{n}^{\mathrm{o}}$ 6.386, de 7 de dezembro de 1976, constituiu, como órgão responsável por essa tutela, a Comissão de Valores Mobiliários, cuja competência pode ser definida, em síntese, pelo exercício de três atribuições principais: regulamentar o mercado de valores mobiliários brasileiro; fiscalizar o cumprimento por seus participantes das normas jurídicas; e sancionar aqueles que as descumpram ${ }^{158}$.

Apresentados os pressupostos em que se fundaram os sistemas jurídicos contemporâneos ao regularem o funcionamento da sociedade anônima e do mercado de capitais, vai-se além. Estabelecer os limites dentro dos quais a regulação de ambos, da companhia e do mercado de capitais, se justifica, diante dos diversos objetivos passíveis de serem endereçados pelo regulador societário, é o próximo desafio com que se ocupa.

\subsection{Easterbrook e Fischel: a teoria do contrato plurilateral ascarelliana e os fundamentos e limites da regulação}

"What is the point of companies? (...). Ronald Coase (...) argued that the main reason why a company exists (as opposed to individual buyers and sellers making ad hoc deals at every stage of production) is because it minimizes the transaction costs of coordinating a particular economic activity" "159 (Micklethwait; Wooldridge, 2005).

Frank Easterbrook e Daniel Fischel definem a sociedade anônima como um complexo de contratos formados livremente pelos agentes que dela se proponham participar $^{160}$. Mesmo aceito o valor retórico da acepção contratual

\footnotetext{
${ }^{157}$ FILHO, Alfredo Lamy; PEDREIRA, José Luiz Bulhões. Op. cit., p. 17.

${ }^{158}$ TRINDADE, Marcelo Fernandez, Op. cit., p. 307.

159 MICKETHWAIT, John; WOOLDRIDGE, Adrian. Op. cit., p. xxii. "Qual é a finalidade das companhias? (...) Ronald Coase argumentou que a principal justificativa para a existência da companhia (em oposição à possibilidade de compradores e vendedores negociarem, individualmente, em cada etapa da cadeia produtiva) consiste no fato de ela minimizar os custos de transação correspondentes a se coordenar uma determinada atividade econômica" Tradução livre.

${ }^{160}$ EASTERBROOK, Frank H.; FISCHEL, Daniel R.. Op. cit., p. 15.
} 
da realidade societária ${ }^{161}$, os autores se valem da teoria geral dos contratos instrumentalmente, de modo a propiciar uma melhor compreensão das relações que se desenvolvem em torno da sociedade anônima.

A origem do modelo teórico proposto por Frank Easterbrook e Daniel Fischel remonta à teoria do contrato plurilateral concebida por Túlio Ascarelli ${ }^{162}$. A construção elaborada pelo comercialista italiano, além de auxiliar na compreensão da sociedade anônima como produto de um semnúmero de relações jurídicas que dela decorrem justifica a existência dos diversos deveres prescritos aos seus administradores. Essas obrigações correspondem, não só a direitos atribuídos aos 'principais' que participem da companhia ou àqueles cujos interesses os administradores da sociedade anônima são indicados para representar, mas sim a prerrogativas genericamente atribuídas aos agentes econômicos. Entende-se, ainda, que as normas dirigidas ao exercício da sociedade anônima e com direta pertinência ao funcionamento do mercado de capitais referem-se ao atendimento daquilo que se convencionou como a 'função social' da companhia, cuja conotação quanto a ser ou não mais ampla à tutela restrita aos interesses de seus diretos participantes é discutida no item 3.3 seguinte deste estudo ${ }^{163-164}$.

\footnotetext{
161 Os autores justificam a utilização da teoria contratual para explicar a natureza da sociedade anônima: "The rhetoric of contract is a staple of political and philosophical debate. Contract means voluntary and unanimous agreement among affected parties. It shows up in argument about "social contracts" that justify political society (...)" Ibid. p. 15. "A retórica do contrato é um instrumento utilizado no debate político e filosófico. Contrato significa um acordo voluntário e consensual entre as partes relacionadas. O contrato é evidenciado em argumentos relacionados a "contratos sociais" que justificam a sociedade política (...) Eles são construções e não necessariamente realidades. É possível que o contrato da sociedade anônima, tal como o contrato social, não seja nada a mais do que um instrumento retórico" Tradução livre.

162 ASCARELLI, Tulio, Problemas das Sociedades Anônimas e Direito Comparado. $2^{\mathrm{a} E d}$. São Paulo: Editora Saraiva, 1969. p. 255 e ss.

${ }^{163}$ A função social da sociedade anônima encontra-se prevista no art. 116, § único da Lei n ${ }^{\circ}$ 6.404/76, ao tratar do dever do acionista controlador: "O acionista controlador deve usar o poder com o fim de fazer a companhia realizar o seu objeto e cumprir sua função social, e tem deveres e responsabilidades frente aos demais acionistas da empresa, os que nela trabalham e para com a comunidade em que atua, cujos direitos e interesses deve lealmente respeitar e atender". A função social da companhia encontra, ainda, matriz na própria CRFB/1988, ao tratar dos direitos e garantias fundamentais, em seu art. $5^{\circ}$,
} 
O fundamento jurídico da capacidade atribuída aos sujeitos em contratar a companhia, permitindo-lhes constituir pessoa jurídica que lhes seja distinta, reside naquilo que Herbert Hart denomina 'regras que conferem direitos'. Sob o modelo analítico do autor, o direito é estritamente compreendido como um modelo de regras composto por duas categorias principais: primárias e secundárias. Para Herbert Hart, enquanto as regras primárias são as que impõem obrigações ou limitações aos sujeitos de direito, as secundárias são as que lhes atribuem a capacidade para, pública ou privadamente, realizar determinados atos jurídicos, tais como constituírem a sociedade anônima ${ }^{165}$.

inciso XXIII, e dos princípios que devem reger a ordem econômica, em seu art. 170, inciso III. Respectivamente: "A propriedade atenderá a sua função social"; e "A ordem econômica, fundada na valorização do trabalho humano e na livre iniciativa, tem por fim assegurar a todos existência digna, conforme os ditames da justiça social, observados os seguintes princípios: função social da propriedade (...)".

${ }^{164} \mathrm{O}$ bom funcionamento da sociedade anônima e do mercado de capitais como instrumento de desenvolvimento social é evidenciado pela história da regulação. John Mickethwait e Adrian Wooldridge narram o episódio da South Sea Bubble, decorrente de um contexto de crescente liquidez e que induziu a uma grave crise econômica, seguida pela maior regulação da sociedade anônima na Europa. MICKETHWAIT, John; WOOLDRIDGE, Adrian. Op. cit., 31. No Brasil, a Exposição de Motivos $n^{\circ} 196$, de 24 de junho de 1976, da Lei n ${ }^{\circ} 6.404 / 76$, enuncia a importância socioeconômica da regulação da sociedade anônima em seu exercício: "O Projeto visa basicamente a criar a estrutura jurídica necessária ao fortalecimento do mercado de capitais de risco no País, imprescindível à sobrevivência da empresa privada na fase atual da economia brasileira". Disponível em <http://www.cvm.gov.br/port/atos/leis/6404_Exposicao.asp> Acesso em 3 Out. 2008.

165 Assim Herbert Hart localiza em seu modelo analítico do direito as normas que conferem poderes aos sujeitos na categoria de regras secundárias: "Under rules of the one type, which may well be considered the basic or primary type, human beings are required to do or abstain from certain actions, whether they wish to or not. Rules of the other type are in a sense parasitic upon secondary to the first; they provide that human beings may by doing or saying certain things introduce new rules of the primary type, extinguish or modify old ones, or in various ways determine their incidence or control their operations. Rules of the first type impose duties; rules of the second type provide for operations which lead not merely to physical movement or change, but to the creation or variation of duties or obligations". HART, H.L.A.. The Concept of Law - with a Postcript edited by Penélope A. Bulloch and Joseph Raz. $2^{\text {nd }}$ Ed.. Oxford: OxfordUniversity Press, 1994. p. 80/81. "Sob as regras do primeiro tipo, as quais podem ser consideradas como básicas ou de tipo primário, são impostas obrigações ou limitações aos indivíduos, independentemente de sua vontade. As regras deste outro tipo são, em certo sentido, parasitárias às primárias; as regras secundárias permitem aos indivíduos, através da introdução de novas regras primárias, que extingam ou modifiquem regras antigas, ou, em diversas formas, determinem ou controlem a incidência das regras primárias. As regras do primeiro tipo impõem deveres, enquanto as do segundo provêem regras que não levam somente a modificações físicas, ou simplesmente alterações, mas à criação e variação de deveres e obrigações" Tradução livre. 


\section{A relevância da classificação proposta por Herbert Hart para o estudo} da sociedade anônima encontra-se na própria natureza de ambas as espécies de regras que compõem o modelo proposto pelo autor: as que conferem poderes aos sujeitos para constituí-la, companhia, e as que lhes impõem obrigações correspondentes à faculdade de contratar a sociedade anônima, dentre as quais se destaca a de, periodicamente, se reportar os resultados sociais ao mercado $^{166}$, e se justificam pela própria finalidade social a que a companhia se destina. Nas diversas interpretações do conteúdo da 'função social' prescrita à companhia, cumpre ao regulador estruturar a sociedade anônima à luz do interesse social decorrente de sua constituição e exercício, conforme se discutiu preliminarmente no item 3.1, e se conclui no item 3.3 seguinte deste ensaio $^{167}$.

Chega-se, assim, a duas conclusões preliminares. Da natureza contratual das relações originárias da sociedade anônima, de constituição

\footnotetext{
${ }^{166}$ Conforme se observou no item 3.1 deste estudo, o dever de informar prescrito aos administradores da sociedade anônima encontra-se previsto ao longo da lei societária e, especificamente o de periodicamente reportar os resultados obtidos pela sociedade anônima na realização de seu objeto social, ao longo do capítulo XV, da Lei $n^{0}$ 6.404/76, e regulamentado pela Instrução CVM n ${ }^{\circ} 202$, de 6 de dezembro de 1993, instituída pela autarquia, com fundamento na sua competência regulamentar prevista no art. $22, \S 1^{\circ}$, inciso I, da Lei 6.386/76.

167 Ian Davis fundamenta o que denomina 'responsabilidade social da sociedade anônima', que decorreria, na concepção do autor, da noção de contrato social rousseauniano implícito relacionado à faculdade atribuída aos sujeitos de direito em constituir a sociedade anônima para o desenvolvimento da atividade econômica organizada. Essa constituição, conforme se notou, possível mediante a positivação da categoria de regras que conferem direitos, prevista no modelo de regras hartiano. Discorre Ian Davis: "Large companies need to build social issues into strategy in a way which reflects their actual business importance. They need to articulate business's social contribution and define its ultimate purpose in a way that has more subtlety than "the business of business is business" worldview (...) It can help to view the relationship between big business and society in this respect as an implicit "social contract": Rousseau adapted for the corporate world, you might say. This contract has obligations, opportunities and mutual advantage for both sides". DAVIS, Ian. The Biggest Contract, The Economist, 2005. Ap. COMISSO, Ellen. Ethics and Society, San Diego: UCSD Bookstore, 2007. p. 114. "Grandes companhias precisam integrar às suas estratégias questões sociais de modo a refletir a importância das mesmas no desenvolvimento de suas atividades. Elas [as companhias] precisam articular a contribuição social de seus negócios e definir a sua finalidade, de uma forma mais complexa que a visão mundial de que "the business of business is business" (...) Pode auxiliar, no alcance desse entendimento, a percepção entre a relação entre grandes negócios e a sociedade como um contrato social implícito. Rousseau adaptado para o mundo corporativo, pode-se dizer. Esse contrato oferece obrigações, oportunidades e benefícios mútuos para ambas as partes: a companhia e a sociedade" Tradução livre.
} 
passível pela prescrição dos poderes para tanto conferidos aos sujeitos de direito, decorrem os deveres que lhes são atribuídos, em correspondência à faculdade de constituir uma pessoa jurídica que lhes seja distinta para o desenvolvimento da atividade econômica organizada e em atenção aos interesses sociais decorrentes desse exercício. Em segundo lugar, as obrigações impostas aos participantes da sociedade anônima não devem ser estritamente compreendidas com relação aos interesses pelo seu bom funcionamento, sobretudo pela importância econômico-social historicamente adquirida pela sociedade anônima e, especificamente, diante do acesso facultado aos participantes da companhia registrada como de capital aberto à poupança popular para o financiamento de suas atividades. Apresentadas tais premissas que, preliminarmente, justificam a existência do direito societário como tal, passa-se ao debate sobre o exato escopo a que o regulador deve se limitar, de modo a, eficientemente, permitir a realização dos propósitos que se pode endereçar à sociedade anônima.

A discussão sobre a legitimidade da regulação em restringir a autonomia da vontade das partes constituintes da sociedade anônima ao lhes prescrever disposições obrigatórias referentes à estrutura e ao funcionamento da companhia relaciona-se aos custos e benefícios decorrentes da própria regulação. Explica-se, de acordo com a terminologia extraída do modelo proposto por Herbert Hart, resta definir quais devem ser as regras primárias ou o exato escopo dos termos mínimos que devem reger as relações decorrentes de toda e qualquer sociedade anônima, em correspondência à faculdade atribuída aos sujeitos de direito por meio das regras ditas secundárias que lhes confiram o poder de constituí-la, companhia, para o desenvolvimento da atividade econômica organizada e diante dos objetivos que se lhe podem prescrever. 
Diversas correntes teóricas propõem limites distintos à regulação da sociedade anônioma vis-à-vis o princípio da autonomia da vontade garantido constitucionalmente aos agentes econômicos e exercitável através da possibilidade de se negociar, privadamente, os termos que devem reger as relações decorrentes da companhia ${ }^{168}$. Frank Easterbrook e Daniel Fischel, na leitura econômica que propõem ao direito societário, defendem que, diante da finalidade própria à companhia, qual seja, possibilitar a obtenção de lucro mediante o desenvolvimento de atividade econômica organizada, deve-se privilegiar a otimização dos resultados advindos de suas atividades na estruturação do funcionamento da sociedade anônima. Nelson Eizirik explica o fundamento econômico relacionado à natureza da sociedade anônima em suas finalidades:

"O objeto econômico da sociedade anônima, indiscutivelmente, é o de produzir lucros e proporcionar a sua partilha entre os acionistas ${ }^{169}$; com efeito, quem compra ações de uma companhia tem em mente, sem qualquer dúvida, um investimento com finalidade lucrativa. O art. 206, II, alínea $b$, da Lei das S.A., comtempla como hipótese de dissolução judicial da companhia a pedido de acionistas o fato de não poder preencher o seu fim; ou seja, em princípio, se a companhia não produzir lucros para distribuí-los entre seus acionistas não está atingindo o seu fim e pode ser dissolvida judicialmente" ${ }^{\text {170 }}$.

A fim de se possibilitar a realização daquilo que Frank Easterbrook e Daniel Fischel compreendem como o ‘modelo estrutural ótimo’ da sociedade anônima, os autores defendem que o regulador deve se restringir a prescrever tão-somente os termos que sejam essenciais a toda e qualquer companhia ${ }^{171}$. Assim, sustentam os autores, permite-se que os participantes da sociedade anônima, supletiva e amplamente, regulem as suas relações, do modo que

\footnotetext{
${ }^{168}$ O artigo $1^{\circ}$, da Constituição de 1988, prevê, em seu inciso IV, a livre iniciativa como valor essencial à República Federativa do Brasil: A República Federativa do Brasil, formada pela união indissolúvel dos Estados e Municípios e do Distrito Federal, constitui-se em Estado Democrático de Direito e tem como fundamentos: IV - os valores sociais do trabalho e da livre iniciativa".

${ }^{169}$ MARTINS, Pedro A. Baptista, O Direito do acionista de participação nos lucros sociais. Revista de Direito Mercantil, no 103, p. 40 Apud. EIZIRIK, Nelson. Reforma da Lei das S.A. Rio de Janeiro: Editora Renovar, $2^{a}$ Ed., 1998. p. 30.

${ }^{170}$ EIZIRIK, Nelson. Reforma da Lei das S.A. Rio de Janeiro: Editora Renovar, 2a Ed., 1998. p. 30.

${ }^{171}$ EASTERBROOK, Frank H.; FISCHEL, Daniel R.. Op. cit., p. 14.
} 
melhor lhes convenha, ao invés de, complexa e exaustivamente, se determine os termos estruturais fundamentais a toda e qualquer sociedade ${ }^{172}$.

Diante dessa variabilidade circunstancial da estrutura dita 'ótima' da companhia, conseqüente dos muitos aspectos peculiares à realidade de cada empreendimento e de seus participantes, Frank Easterbrook e Daniel Fischel preceituam os principais aspectos daquilo que se pode chamar 'teoria estrutural 'mínima' da sociedade anônima', já que:

"Just as there is no right amount of paint in a car, there is no right relation among managers, investors, and other corporate participants. The relation must be worked out one firm at time" ${ }^{, 173}$.

A premissa econômica em que se baseiam os autores é de que o valor atribuído pelo mercado à sociedade anônima é, dentre outros fatores e à luz das reações dos agentes participantes do mercado às informações divulgadas pela companhia, conforme se discutiu no item 3.1 deste ensaio, também direta conseqüência da forma como são estruturadas as suas relações internas e externas Ao final, o modo como são reguladas as relações decorrentes da companhia afeta diretamente a perspectiva de lucro que o investidor possui:

"The price reflects the effects, good or bad, of corporate law and contracts, just as it reflects the effects of good and bad products. This is yet another example of the way in which markets transmit the value of information through price, which is more "informed" than any single participant in the market ${ }^{, 174}$.

Inclusive, pois: "the price of stocks traded in public markets is established by professional investors, not by amateurs" $" 175$.

\footnotetext{
${ }^{172}$ Ibid. p. 14.

173 Ibid. p. 14. "Assim como não existe a quantidade exata de tinta para se pintar um carro, não existe uma relação uniforme entre administradores, investidores e outros participantes da sociedade. A relação deve ser definida em cada companhia" Tradução livre.

${ }^{174}$ Ibid. 19. "O preço reflete os efeitos, positivos ou negativos, do direito societário e dos contratos, assim como reflete os efeitos de produtos bons e ruins. Este é, contudo, um outro exemplo do modo como os mercados transmitem o valor da informação através do preço, que é melhor "informado" que qualquer participante do mercado" Tradução livre.

${ }_{175}$ Ibid. p. 18. "o preço das ações negociadas no mercado é determinado por investidores profissionais, e não por amadores” Tradução livre.
} 
Segundo a concepção de Frank Easterbrook e Daniel Fischel, são as forças de mercado, por meio da livre-competição entre os seus agentes participantes, que, assim como determinam o preço dos valores nele negociados, dimensionam o modelo regulamentar dito 'ótimo' à realidade de cada companhia, em atenção às peculiaridades de cada sociedade e de seu objeto e também no que tange à regulação da teia de relações decorrentes da sociedade:

"Self-interested entrepreneurs and managers, just like other investors, are driven to find the devices most likely to maximize net profits. If they do not, they pay for their mistakes because they receive lower process for corporate paper. Any one firm may deviate from the optimal measures. Over ten years and thousands of firms, though, tendencies emerge. The firms and managers that make the choices investors prefer will prosper relative to others ${ }^{\prime 176}$.

Como fundamento e, em acréscimo à sua compreensão ampla sobre 'o que' deve ser objeto da regulação, a teoria estrutural mínima da sociedade anônima proposta pelos autores tem como principal fundamento o custo que a regulação impõe à atividade econômica objeto da companhia. Assim, a fim de que o direito realize o propósito de otimizar o ganho de bem-estar social derivado da atividade econômica desenvolvida pela sociedade anônima, é elementar que a regulação da companhia se restrinja ao que não puder ser mais bem realizado mediante arranjos privados. Sobretudo, tendo-se em vista os custos decorrentes da regulação:

"The question is whether these costs can be cut by mechanisms that are not themselves more costly. Investors, like all of us in our daily lives, accept some unwelcome conduct because the costs of the remedy are even greater" ${ }^{\prime 17}$.

\footnotetext{
${ }^{176}$ Ibid. p. 6. "Empreendedores e administradores, na busca de seus interesses individuais, assim como qualquer outro investidor, são levados a encontrar e adotar instrumentos mais propícios à maximização dos resultados sociais. Caso não o façam, pagarão por seus erros, pois receberão menos em contrapartida aos títulos emitidos pela companhia. Qualquer companhia poderá se desviar dos níveis ótimos regulamentares à sua atividade. Embora, após anos e inúmeras companhias, tendências emerjam. As companhias e os administradores que adotam as opções preferidas pelos investidores tendem a prosperar em relação aos demais" Tradução livre.

${ }^{177}$ Ibid. p. 7. "A questão é saber se estes custos [decorrentes da regulação] podem ser cortados por mecanismos que não são em si mais elevados que o objeto a que endereçam. Investidores, assim como
} 
Analogamente e a fim de melhor explicar os custos que o regulador pode impor ao desenvolvimento da atividade econômica organizada os autores remetem às vantagens comparativas e à maior eficiência apresentadas por sistemas jurídicos em sentido amplo de raízes anglo-saxônicas do tronco da Common Law, ou da espécie 'judge-made law', em relação a sistemas de origem romano-germânica ${ }^{178}$, pois:

"Court systems have a comparative advantage in supplying answers to questions that do not occur in time to be resolved ex ante. Common law systems need not answer questions unless they occur. This is an economizing device" ${ }^{, 179}$.

Pela mesma razão, Frank Easterbrook e Daniel Fischel compreendem que o direito societário deve propiciar aos agentes econômicos um sistema regulatório da companhia que lhes permita regular as suas relações, em atenção ao que melhor lhes convier. Assim, ao invés de se, regulamentarmente, prescrever estruturas societárias complexas e obrigatórias que imponham custos à realização da empresa pela companhia, ou de preferirse, ainda, interesses particulares na prescrição de regras estruturais à sociedade anônima, o regulador societário deve, genericamente, buscar otimizar o bem-estar decorrente da atividade econômica realizada pela companhia $^{180}$.

Segundo os autores, somente a regulação mínima da estrutura da companhia é capaz de, eficientemente, endereçar à realidade de cada sociedade anônima. Isso à luz, tanto das peculiaridades decorrentes das diversas modalidades de empresas que podem constituir o objeto social da

\footnotetext{
todos nós em nossas vidas diárias, aceitam determinadas condutas indesejadas, porque os custos do remédio são maiores que os das mesmas" Tradução livre.

${ }^{178}$ DAVID, René. Os Grandes Sistemas do Direito Contemporâneo. $4^{\mathrm{a}}$ Ed. Rio de Janeiro: Marins Fontes, 2002. p. 381 e ss.

179 EASTERBROOK, Frank H.; FISCHEL, Daniel R.. Op. cit., p. 35. "Court System possui a vantagem comparativa de respostas a questões que não ocorrem em tempo de serem resolvidas ex-ante. Sistemas jurídicos típicos a Common Law não precisam responder questões, salvo quando elas ocorrem. Isso é um instrumento que gera economia" Tradução livre.

${ }^{180}$ Ibid. p. 28.
} 
companhia, como das relações entre os seus participantes. Na definição do grau ideal da regulação de cada sociedade, defendem, somente devem ser considerados os custos e benefícios marginais correspondentes à regulação aferidos pela própria companhia. Já que, conforme sustentam, os mecanismos de governança ou de estruturação das relações entre os participantes da sociedade anônima não são passíveis de gerar efeitos substanciais a terceiros $^{181}$. Com efeito, conforme se discute adiante, da mesma forma que se pode questionar a lógica da irrestrita liberdade de contratar dos agentes econômicos como justificativa para a regulação mínima da sociedade, é necessário relativizar a premissa em que se baseiam os autores de que a regulação das relações internas na sociedade anônima não é passível de gerar externalidades. Consumidores, empregados, credores e, sobretudo, a sociedade como um todo, se beneficiam de uma regulação da sociedade anônima que otimize os resultados sociais dela decorrentes. A contrario sensu, a regulação interna ineficiente das relações da companhia pode levar a perda de bem-estar social em seu exercício e, conseqüentemente, gerar externalidades consideráveis, como, por exemplo, se verificou na falência da Enron decretada em dezembro de 2002 e relacionada a fraudes corporativas, que acarretou a extinção de milhares de postos de emprego nos Estados Unidos $^{182}$.

Alcança-se, enfim, o nível regulamentar dito 'ótimo' da sociedade anônima a que se referem Frank Easterbrook e Daniel Fischel em sua leitura econômica proposta, ou aquele em que os custos e benefícios marginais respectivos às normas de sua estruturação e funcionamento se equalizem. Somente aos participantes diretos e indiretos voluntários da companhia contratantes, empregados, investidores ou aos seus credores voluntários -

\footnotetext{
${ }^{181}$ Ibid. p. 17.

${ }^{182} \mathrm{O}$ histórico do caso Enron e as deficiências da regulação de seu exercício encontram-se disponíveis em <http://www.enronfraudinfocenter.com/information.php>, Acesso em 3 Out. 2008.
} 
caberia definir, atendido o bojo estrutural prescrito pelo regulador societário e cujos limites são discutidos a seguir, os termos em que devem ser regidas suas relações como participantes voluntários da sociedade anônima. Aos que deles discordem, resta a opção de contratar com uma outra sociedade ou de não fazê-lo absolutamente, numa equação em que é o próprio mercado que define os termos sobre os quais devem ocorrer as relações decorrentes da companhia $^{183}$. Inevitável reproduzir as palavras dos próprios autores nesse sentido:

"The corporation's choice of governance mechanisms does not create substantial third-party effects - that is, does not injure persons who are not voluntary participants in the venture (...) Investors, employees, and others can participate or go elsewhere" ${ }^{\text {"184 }}$.

São muitas as críticas que se pode realizar à estrita lógica da liberdade de contratar em que se funda a teoria estrutural mínima da sociedade anônima proposta por Frank Easterbrook e Daniel Fischel. Pode-se questionar a categorização proposta pelos autores ao que se referem como "participantes voluntários' da companhia, como, por exemplo, seus empregados, em condições econômicas aquém a níveis de pleno-emprego, ou em mercados com condições de demanda por trabalho monopsônicas ${ }^{185}$.

\footnotetext{
183 Ainda com respeito à natureza intrinsecamente econômica da sociedade anônima, John Micklethwait e Adrian Wooldridge discorrem: "Companies increase the pool of capital available for productive investment. They allow investors to spread their risk by purchasing small and easily marketable shares in several enterprises. And they provide a way of imposing effective management structures on large organizations. Of course companies can ossify, but the fact that investors can simply put their money elsewhere is a powerful rejuvenator". MICKETHWAIT, John; WOOLDRIDGE, Adrian. Op. cit., p. xxi. "Companhias aumentam a quantidade de capital disponível para o investimento produtivo. Permitem a investidores mitigar o seu risco através da compra de pequenas parcelas de valores mobiliários com grande liquidez no mercado e em distintos empreendimentos e oferecem um meio de se impor estruturas administrativas eficientes em grandes organizações. Obviamente, companhias podem estagnar, mas o fato de que investidores podem, simplesmente, levar o seu investimento a outras companhias é um poderoso instrumento rejuvenescedor" Tradução livre.

${ }^{184}$ Ibid. p. 17. "A escolha dos mecanismos de governança da companhia não gera efeitos substanciais sobre terceiros - isso é, não prejudica aqueles que não sejam participantes voluntários do empreendimento (...) Investidores, empregados e outros podem participar [da companhia] ou dela sair" Tradução livre.

${ }^{185}$ PARKIN, Michael. Op. Cit., p. 412/413.
} 
Da teoria dos autores destaca-se a tese central de que a alocação apropriada dos direitos dos participantes na sociedade anônima somente é possível em atenção à realidade de cada sociedade. Essa idéia evidencia as perplexidades relacionadas à própria essência do direito societário, tal qual o conhecemos, e que adquirem especial relevo na regulação do exercício do controle na sociedade anônima. Afinal: "Who governs? For whose benefit?"186 Como resposta à segunda questão, Frank Easterbrook e Daniel Fischel sugerem: "What is optimal for the firms and investors is optimal for society" ${ }^{\prime 187}$.

Permitir aos participantes da sociedade anônima que, livre, contratualmente e, de acordo com os interesses que lhes sejam peculiares, regulem os termos sobre os quais as suas relações devem ser regidas, mostrase, preliminarmente, como o meio mais adequado a se permitir o alcance social ótimo dos resultados obtidos através dessa estrutura jurídica que é a companhia.

É a essas indagações e de acordo com a exposição dos pressupostos da análise funcional do direito que se busca responder a seguir.

\subsection{A ratio do direito societário à luz do modelo de regras hartiano: escopo, objetivos e o dever de fidúcia na sociedade anônima}

"Some day when English history is adequately written one of the most interesting and curious tales that it will have to tell will be that which brings trust and corporation into intimate connection with each other" 188 (Maitland, 1911).

\footnotetext{
${ }^{186}$ EASTERBROOK, Frank H.; FISCHEL, Daniel R.. Op. cit., p. 14. "Quem controla? E em benefício de quem?" Tradução livre. No item 3.3. seguinte deste estudo, discutem-se as finalidades a que o regulador societário pode remeter à luz da dita 'função social' da sociedade anônima.

${ }^{187}$ Ibid. p. 8. "O que é ótimo para as companhias e para os investidores é ótimo para a sociedade" Tradução Livre.

${ }^{188}$ MAITLAND, F. The Unincorporated Body, In: 3, Collected Papers, 272. 1911. Ap. BAYNE, David Cowan. Op. cit., p. 34. "Algum dia, quando a história da Inglaterra for adequadamente escrita, um dos
} 
Uma das principais justificativas à existência do direito societário é possibilitar, mediante a estruturação genérica de tipos societários, a sua adoção por agentes econômicos que, sem tal previsão, não o fariam privadamente. À luz dos pressupostos em que se funda a análise funcional do direito, proporcionar, genericamente, modelos estruturais regulamentares das relações decorrentes da sociedade anônima, livres dos custos de transação em que os agentes econômicos precisariam incorrer, caso necessitassem negociar os termos que regeriam o exercício de cada companhia a ser contratada, é um dispositivo econômico que legitima a regulação societária eficientemente ${ }^{189}$. Disto se infere que, diante das limitações que, sob um prisma funcional, devem ser atendidas pelo regulador, conforme compreendido na concepção da teoria mínima da estrutura da sociedade anônima discutida no item 3.2. anterior deste capítulo, o ordenamento jurídico deve prever não mais do que a raiz estrutural regulamentar elementar ao funcionamento de toda e qualquer sociedade anônima. Isso, de modo a permitir tanto a sua livre contratação pelos sujeitos de direito, quanto que aos mesmos se faculte regular privada e

\footnotetext{
mais interessantes e curiosos contos que precisará ser narrado será o que trata a companhia e o trust como intimamente relacionados" Tradução livre.

${ }^{189}$ Ao tratarem dos custos de transação respectivos à estruturação das relações da sociedade anônima e das diferenças dos benefícios marginais entre grandes e pequenas companhias, bem como dos benefícios que pequenos investidores e companhias auferem das estruturas desenvolvidas por sociedades de maior porte, Frank Easterbrook e Daniel Fischel sintetizam a importância econômicosocial em se prever os termos gerais que permeiam o exercício da companhia, através da prescrição de regras estruturais da sociedade anônima: "Differences in transaction costs or perspicacity are more plausible unless there is some identifiable difference that calls for different rules of governance. Larger firms will find it worthwhile to specify things others leave open, because the gains from resolution increase with the size of the firm. As amateur investors benefit from the work of professionals, so smaller firms can benefit from the work of professional negotiators who solve problems for larger firms". EASTERBROOK, Frank H.; FISCHEL, Daniel R.. Op. cit., p. 34. "Diferenças nos custos de transação ou perspicácia são mais plausíveis, a não ser que exista alguma particularidade identificável que demande a existência de regras de governança específicas. Grandes companhias entendem que é válido o esforço em especificar relações que outras deixam em aberto, tendo em vista que os ganhos em se prever certas estruturas crescem na mesma proporção que o tamanho da companhia. Assim como investidores amadores se beneficiam da atividade de profissionais, pequenas companhias também se beneficiam da atuação de negociadores profissionais que resolvem problemas estruturais para grandes companhias" Tradução livre.
} 
amplamente as suas relações, de acordo com as peculiaridades que apresentem $^{190}$.

Em atenção a tais limitações da regulação, Henry Hassmann e Reinier Kraakman destacam duas principais funções que devem ser exercidas pelo direito societário e que justificam a sua existência pelos fundamentos econômicos apresentados: prescrever as regras elementares à estrutura básica da sociedade anônima e regulamentar as relações entre os seus participantes ${ }^{191}$. Para ambas e, em acréscimo à regra negativa de regulação elaborada por Frank Easterbrook e Daniel Fischel, conclui-se que o direito societário deve estruturar a sociedade anônima, mediante a regulação da relação entre seus participantes, naquilo que não puder ser mais bem realizado diretamente pelos mesmos ${ }^{192}$.

As restrições à possibilidade de, exaustivamente, se regular todas as relações jurídicas decorrem, ainda, da multiplicidade que o fenômeno jurídico e, aqui, especificamente, que a sociedade anônima, apresenta. Herbert Hart baseia as razões da impossibilidade em se compreender todas as relações jurídicas sob o direito positivo em duas dimensões distintas. A primeira de natureza quantitativa, pois, conforme observa, a mesma capacidade criativa humana que torna o direito um fenômeno social vivo e contínuo restringe a possibilidade de se prever, conclusiva e exaustivamente, todas as relações

\footnotetext{
${ }^{190}$ Ibid. p. 15.

191 Explicam os autores: "Corporate law performs two general functions: first, it establishes the structure of the corporate form as well as ancillary housekeeping rules necessary to support this structure; and, second, it attempts to control conflicts of interest among corporate constituencies, including those between corporate 'insiders' such as controlling shareholders and top managers, and 'outsiders,' such as minority shareholders or creditors". HANSMANN, Henry; KRAAKMAN, Reinier. What's Corporate Law? In. KRAAKMAN, Reinier et. al. The Anatomy of Corporate Law: a Comparative and Functional Approach. New York: Oxford University Press. p. 20. "O direito societário possui duas funções principais: primeiro, estabelece a estrutura dos tipos societários, assim como as suas regras estruturais necessárias e, em segundo lugar, o direito societário busca regular os conflitos de interesse entre as partes que constituem a companhia, incluindo aqueles entre os 'insiders' da companhia, assim como acionistas controladores e administradores, e os seus 'outsiders', como os acionistas minoritários e os seus credores" Tradução livre.

${ }^{192}$ EASTERBROOK. Frank; FISCHEL, Daniel. Op. cit., p. 1 e ss.
} 
exercitáveis pelos sujeitos de direito (do que se infere o reconhecimento de situações jurídicas atípicas). E a segunda, de natureza interpretativa e que decorre da dimensão qualitativa, pois, diante da impossibilidade de se compreender, sob o direito positivo, todo o fenômeno jurídico, a interpretação da juridicidade das relações previstas ou não no ordenamento jurídico, nele, não se esgota ${ }^{193}$.

Assim, à luz da analítica hartiana, a não-exaustividade do direito positivo é compreendida como característica que lhe é intrínseca. Ao escopo do presente ensaio, a percepção das limitações existentes tanto ao regulador societário, quanto às partes constituintes da sociedade anônima, em regular, específica e pormenorizadamente, todas as situações passíveis de ocorrer no exercício da companhia, são especialmente relevantes ao estudo da aplicação de enunciados normativos ditos abertos ou indeterminados, no que tange às relações decorrentes da transferência de controle na sociedade anônima. A discussão dos instrumentos regulatórios e de governança apresenta-se em seguida no item 3.4 deste capítulo, diante do instrumental propiciado pela construção teórica dos problemas de agência decorrentes da estrutura da sociedade anônima.

Dessa forma, diante da inevitabilidade do inesperado, destacam-se princípios e padrões (standards) que possibilitam a interpretação das relações

\footnotetext{
${ }^{193}$ Herbert Hart explica as razões dessa limitação: "There is also my general argument that, even if laws could be framed that could settle in advance, all possible questions that could arise about their meaning, to adopt such laws would often war with other aims which law should cherish. A margin of uncertainty should be tolerated, and indeed welcomed in the case of many legal rules, so that an informed judicial decision can be made when the composition of an unforeseen case is known and the issues at stake in its decision can be identified and so rationally settled". HART, Herbert, Op. cit., p. 52. "Persiste o meu argumento de que mesmo caso as leis pudessem ser elaboradas de modo a antecipar todas as questões que pudessem surgir sobre o seu significado, a adoção dessas normas levaria ao conflito com outros objetivos que o direito deve proteger. Uma margem de incerteza deve ser tolerada e, até mesmo desejada, no caso de muitas normas, de modo que uma decisão judicial embasada possa ser tomada mesmo diante da composição de um caso inesperado, através de sua observação e da identificação dos assuntos em questão que, dessa forma, são racionalmente estabelecidos" Tradução livre.
} 
entre os participantes da sociedade anônima, tais como a construção teórica resultante da leitura ampla do conceito de 'dever de fidúcia'. A origem do verbete 'fiduciário' remonta ao termo em latim 'fiduciarius', referente à expressão: "an actual holding in trust", "Que, como tal: "it was synonimous with the present-day usage "in trust",195. E a qual o autor esclarece: "It means (...) "of, relating to, or involving a confidence or trust." Ultimately, it is reducible to 'fides', 'faith' or 'confidence",196.

$\mathrm{Na}$ língua inglesa, o desenvolvimento da acepção do termo 'fidúcia' induziu à ampliação exegética de seu escopo e aplicação, de modo a abarcar relações jurídicas outras que não as decorrentes do trustee, típico aos sistemas jurídicos em sentido estrito, cuja origem se remete ao tronco da Common $L a w^{197}$. Progressiva e extensivamente, o termo 'fidúcia' adquiriu especial relevo também no estudo das relações entre as partes integrantes da companhia. As principais limitações ao exercício de poder de controle na condução das relações internas da sociedade anônima residem justamente no dever de fidúcia que o controlador possui genericamente frente aos demais participantes da sociedade anônima ${ }^{198}$, o qual também se deduz da relação

\footnotetext{
${ }^{194}$ BAYNE, David Cowan. Op. cit., p. 33.

195 Ibid. p. 33. "Dessa forma, [o termo 'fiduciário'] era sinônimo à utilização presente da expressão 'in trust"” Tradução livre.

${ }^{196}$ Ibid.. p. 36/37. "[o termo 'fiduciário'] significa (...), relacionado a ou que envolva a confiança ou trust." Finalmente, ele é reduzível à 'devoção', 'fé', ou 'confiança'” Tradução livre.

${ }^{197}$ DAVID, René. Op. cit., p. 353 e ss.

198 Dessa mesma forma entende Kenneth Clarkson: "In some instances, a majority shareholder is regarded as having a fiduciary duty to the corporation and to the minority shareholders. This occurs when a single shareholder (or a few shareholders acting in concert) owns a sufficient number of shares to exercise de facto (actual) control over the corporation. In these situations, majority shareholders owe a fiduciary duty to minority shareholders". CLARKSON, Kenneth et. al. Op. cit., p. 801. "Em alguns casos, um acionista majoritário é percebido como detentor de um dever de fidúcia frente à companhia e aos acionistas minoritários. Isso ocorre quando um só acionista (ou alguns acionistas em conjunto) possui um número suficiente de ações para exercer o controle efetivo sobre a companhia. Nessas situações, acionistas majoritários possuem um dever de fidúcia em relação aos minoritários" Tradução livre.
} 
entre administradores e acionistas da companhia ${ }^{199}$. Conforme elucida David Cowan Bayne:

"Thus, broadly defined as 'confidence', the term is a genus of which a variety of species accounts for the variety of nontrust relations, which in turn account for much of the difficulty over the decades with the term 'fiduciary duty',. 200

No ordenamento norte-americano, Kenneth Clarkson destaca a existência do dever de fidúcia do agente indicado para atuar em nome do principal e que, conforme se analisa no item 3.4 seguinte deste estudo, caracteriza o fundamento das relações entre as partes integrantes da sociedade anônima. Assim remete o autor ao se referir ao conceito de uma relação típica de agência uma relação típica de agência:

"Section 1 (1) of the Restatement (Second) of Agency defines agency as "the fiduciary relation [that] results from the manifestation of consent by one person to another that the other shall act in his [or her] control, and consent by the other so to act" ${ }^{201}$

Dessa concepção ampla, David Cowan Bayne desenvolveu a sua filosofia do poder de controle que parte da premissa de que o controlador atua,

\footnotetext{
${ }^{199}$ A existência do 'dever de fidúcia' entre administradores e acionistas foi utilizada como principal fundamento pela Suprema Corte de Delaware em 2003, na decisão de MM. Companies Inc. v Liquid Áudio, Inc. No caso, se entendeu ilícita a deliberação adotada pelos pelos membros da diretoria da companhia em alterar a sua composição, sem apresentarem uma justificativa fundamental e necessária. A peculiaridade do caso é que se constatou como a potencial influência que os novos diretores exerceriam quando eleitos (e como representantes dos acionistas minoritários) seria anulada diante do aumento do número total de membros da diretoria da sociedade. $\mathrm{O}$ caso é analisado em profundidade no item 1.3 deste estudo. Ibid. p. 787. Sobre a interpretação do dever de fidúcia dos administradores da sociedade anônima, Kenneth Clarkson esclarece: "Directors and officers are deemed to be fiduciaries of the corporation because their relationship with the corporation and its shareholders is one of trust and the confidence. As fiduciaries, directors and officers owe ethical - and legal - duties to the corporation and the shareholders. These fiduciary duties include the duty of care and the duty of loyalty". Ibid.. p. 789. "Os administradores da companhia são compreendidos como seus fiduciários, em razão de a relação que possuem com a sociedade anônima e com os seus acionistas se caracterizar como de trust e confiança. Na qualidade de fiduciários, diretores e membros do conselho de administração possuem o dever ético e legal frente à companhia e aos seus acionistas. Tais deveres fiduciários incluem os deveres de cuidado e de lealdade". Tradução livre. No mesmo sentido, EASTERBROOK, Frank H.; FISCHEL, Daniel R.. Op. cit., p. 109.

${ }^{200}$ BAYNE, David Cowan. Op. cit., p. 36/37. “Assim, concebida amplamente como 'confiança', a expressão [dever de fidúcia] é um gênero de qual decorrem espécies de um sem-número de relações que não o trust, e que, em seu lugar, é relacionada com a enorme dificuldade que persiste há décadas com relação à aplicação do 'dever de fidúcia'” Tradução livre.

${ }^{201}$ CLARKSON, Kenneth W. et. al. Op. cit., p. 636. "A Seção 1 (1) do segundo Restatement sobre Agência a define como "uma relação fiduciária resultante do consentimento de um indivíduo em relação a outro de que este deve agir sob o consentimento e controle daquele". Tradução livre.
} 
na condução em nome da sociedade anônima dos negócios sociais, como um trustee dos demais acionistas da companhia ${ }^{202-203}$. O sentido e alcance da existência do 'dever de fidúcia' entre as partes integrantes da sociedade anônima e inerente às relações típicas de agência serão, ainda, particularmente relevantes no estudo desenvolvido no final do capítulo 4 deste estudo, quando são discutidos os fundamentos para a alocação de direitos correspondentes à adoção de estratégias de defesa à tomada hostil de controle na sociedade anônima.

Com efeito, além de auxiliar na compreensão da natureza das relações decorrentes da sociedade anônima, o dever de fidúcia possibilita que sejam preenchidas as lacunas inevitavelmente deixadas pelo regulador e pelas partes contratantes da companhia. Conforme elucida Herbert Hart, da impossibilidade em se prever ex-ante todas as relações possíveis entre os participantes da sociedade anônima e a sua juridicidade, seja sob o direito positivo ou contratualmente, construiu-se o dever de fidúcia, como instrumento de interpretação dos negócios sociais e, ao que aqui é mais importante, do estudo das relações decorrentes da transferência de controle na sociedade anônima. Assim entendem Frank Easterbrook e Daniel Fischel:

\footnotetext{
${ }^{202}$ BAYNE, David Cowan. Op. cit., p. 36/37.

${ }^{203}$ Em oposição a David Cowan Bayne, Kenneth Clarkson adota o sentido estrito do negócio jurídico de trustee, ao se recusar a identificá-lo, em sua natureza, à relação jurídica existente entre a companhia e os seus administradores: "Directors are also sometimes incorrectly characterized as trustees because they occupy positions of trust and control over the corporation. Unlike trustees, however, they do not own or hold title to property for the use and benefit of others". CLARKSON, Kenneth W. et. al. Op. cit., p. 786. "Algumas vezes, os administradores são incorretamente caracterizados como trustees, por ocuparem uma posição de confiança e controle na companhia. No entanto, diferentemente de trustees, administradores não são proprietários ou portadores de qualquer outro título para o uso ou benefício de terceiros" Tradução livre. No entanto, deve-se entender a acepção 'trustee' adotada na filosofia de poder de controle de David Cowan Bayne como instrumento cognoscitivo à compreensão do dever de fidúcia dos administradores da companhia no exercício de suas atribuições frente à mesma e aos seus acionistas. BAYNE, David Cowan. Op. cit., p. 36/37. A acepção de trust e de agência em seus sentidos amplos é útil à análise funcional proposta ao presente estudo, cujos fundamentos metodológicos são discutidos no item 3.4 seguinte deste trabalho.
} 
"People cannot see the future well enough to resolve all contingencies ahead of time. Corporations are enduring (relational) contracts. Some persons' rights might be specified. Those of suppliers, laborers, and debt investors fall in this category ${ }^{204}$.

Com relação aos direitos prescritos aos demais, concluem: "If contracts can be written in enough detail, there is no need for fiduciary"205.

Justifica-se o dever de fidúcia não somente como princípio orientador per se na condução dos negócios sociais, mas sim por sê-lo instrumentalmente na qualidade de standard, em função da eficiência na aplicação e interpretação do direito. Assim, possibilita-se aos reguladores e participantes da sociedade anônima orientarem os temos pelos quais devem ser regidas as relações societárias de forma eficiente, sem que, custosamente e em vão, se busque prever todas as situações pertinentes à esfera jurídica passíveis de ocorrerem, reduzidos os custos inerentes à regulação.

As dificuldades relacionadas à aplicação do 'dever de fidúcia' na sociedade anônima não se limitam, entretanto, às duas esferas apresentadas: sua conceituação e natureza instrumental para a aplicação e interpretação do direito societário. Afinal, conforme evidenciou o juiz Felix Frankfurter ao endereçar a opinião da Suprema Corte norte-americana em SEC v. Chenery Corp., julgado em 1943, são muitas as perplexidades decorrentes da aplicação do dito 'dever de fidúcia' na sociedade anônima: "To say that a man is a fiduciary only begins analysis (...) To whom is he a fiduciary? What obligations does he owe as a fiduciary?",206

\footnotetext{
${ }^{204}$ EASTERBROOK, Frank H.; FISCHEL, Daniel R.. Op. cit., p. 90. “As pessoas não conseguem antever o futuro para resolver todas as contingências antes que ocorram. Companhias são contratos permanentes e relacionais. Os direitos de alguns indivíduos podem ser especificados. Aqueles de fornecedores, empregados e debenturistas encontram-se nessa categoria". Tradução livre.

${ }^{205}$ Ibid. p. 90. "Se contratos pudessem ser escritos de forma suficientemente detalhada, não existiria a necessidade da figura do fiduciário" Tradução livre.

${ }^{206}$ Ibid. p. 90. "Afirmar que alguém é fiduciário de outrem somente permite começar a análise (...) De quem ele é fiduciário? Quais obrigações ele possui nessa qualidade?” Tradução livre.
} 
Mais ainda, as questões relacionadas à interpretação da extensão do 'dever de fidúcia' na sociedade anônima são intrinsecamente relacionadas à própria função endereçada à companhia e que, socialmente, legitima a sua contratação pelos agentes econômicos. A compreensão da verdadeira 'função social' da sociedade anônima é fundamental tanto à prescrição das regras que compõem o seu bojo estrutural e das relações dela decorrentes, como, principalmente, se quaisquer limitações relacionadas aos anseios sociais respectivos ao funcionamento da companhia são justificáveis. Seria o objetivo último da sociedade anônima, afinal:

"Is it profit? For whom? Social welfare more broadly defined? Is there anything wrong with corporate charity? Should corporations try to maximize profit over the long run or the short run?"207

São díspares as concepções de diversos autores sobre a real 'função social' a que a companhia, concebida como instrumento para o desenvolvimento da atividade econômica organizada se destina. Enquanto Milton Friedman sustenta que a responsabilidade social da sociedade anônima é a de, progressiva e continuamente, aumentar seus lucros ${ }^{208}$, Ian Davis defende, como elemento harmonizador da finalidade lucrativa da companhia, a efetiva geração de bem-estar social decorrente de seu exercício. Isso, não por meio da otimização de seus resultados estritamente percebidos, mas sim mediante a realização daquilo que conceitua 'responsabilidade social da companhia ${ }^{209}$.

\footnotetext{
${ }^{207}$ Ibid. p. 35/36. [o objetivo final da companhia] é lucro? Para quem? Seria a geração de bem-estar social mais amplamente compreendido? Há qualquer coisa errada com a realização de doações voltadas à caridade pela sociedade anônima? Companhias deveriam buscar maximizar os seus lucros no longo ou no curto prazo?" Tradução livre.

208 FRIEDMAN, Milton. The Social Responsibility of Business is to Increase Its Profits. Ap. COMISSO, Ellen. Op. cit., p. 103.

${ }^{209} \mathrm{O}$ autor constrói o seu raciocínio, no qual fundamenta a responsabilidade social da companhia, em torno das críticas que endereça à concepção pragmática de Milton Friedman sobre a verdadeira função social da sociedade anônima. Assim Ian Davis sintetiza o argumento de Milton Friedman: "On one side of the current debate are those who argue that (to borrow Milton's Friedman's phrase) the
} 
Em seu lugar, a concepção que Frank Easterbrook e Daniel Fischel oferecem ao conceito de 'função social' da companhia é, em si, esclarecedora:

"Who cares? If the New York Times is formed to publish a newspaper first and make a profit second, no one should be allowed to object. Those who came in at the beginning consented, and those who came later bought stock the price of which reflected the corporation's tempered commitment to a profit objective" ${ }^{\text {,210 }}$.

\section{E concluem:}

"A manager told to serve two masters (a little for the equity holders, a little for the community) has been freed of both and is answerable to neither. Faced with a demand from either group, the manager can appeal to the interests of the other. Agency costs rise and social wealth falls" ${ }^{\prime 211}$.

\section{O fundamento da identidade entre o interesse social sobre o exercício}

da sociedade anônima ao dos acionistas, em oposição à doutrina clássica sobre a qual se sustenta a distinção entre o interesse privado da atividade econômica organizada e a sua dita 'função social', ${ }^{212}$ baseia-se em dois pressupostos

\footnotetext{
"business of business is business". This belief is most established in Anglo-Saxon economies. On this view, social issues are peripheral to the challenges of corporate management. The sole legitimate purpose of business is to create shareholder value". DAVIES, Ian. Op. cit., Ap. COMISSO, Ellen, Op. cit., p. 114. "Num dos lados do debate atual [sobre a função social da companhia] encontram-se aqueles que defendem que (utilizada a frase de Milton Friedman) o "business de business é business". Essa posição é melhor estabelecida nas economias anglo-saxônicas. Nessa perspectiva, assuntos sociais são periféricos aos desafios da administração da sociedade anônima. $O$ único propósito legítimo da companhia é o de gerar lucros para os seus acionistas" Tradução livre.

${ }^{210}$ EASTERBROOK, Frank H.; FISCHEL, Daniel R.. Op. cit., p. 36. “Quem se importa?” Se o New York Times foi constituído para produzir jornais em primeiro lugar e, em segundo, para gerar lucro, a ninguém deveria ser permitido se opor. Aqueles que constituíram a sociedade consentiram com esses propósitos e aqueles que, em seguida, compraram as ações da sociedade, o fizeram pelo preço que refletiu o compromisso restrito da companhia em gerar lucro" Tradução livre.

${ }^{211}$ Ibid. p. 38. "Um administrador com ordens para servir a dois mestres (um pouco aos acionistas, e outro, à comunidade) foi libertado de ambos e não responde a nenhum. Demandado por qualquer dos dois grupos, o administrador pode recorrer aos interesses do outro. Custos decorrentes da agência crescem, e o bem-estar social gerado pela companhia cai” Tradução livre.

${ }^{212}$ Assim se fez no ordenamento brasileiro, ao se prescrever, no parágrafo único, do artigo 116, da Lei $\mathrm{n}^{\mathrm{o}}$ 6.404/76, os deveres do acionista controlador: "O acionista controlador deve usar o poder com o fim de fazer a companhia realizar o seu objeto e cumprir sua função social, e tem deveres e responsabilidades para com os demais acionistas da empresa, os que nela trabalham e para com a comunidade em que atua, cujos direitos e interesses deve lealmente respeitar e atender". Em seu lugar, Henry Hansmann e Reinier Kraakman assim apresentam os principais elementos sobre os quais a teoria que se funda na divergência entre o interesse social genericamente observado e o dos participantes da sociedade anônima se baseia: "As a normative matter, the overall objective of corporate law - as any branch of law - is presumably to serve the interests of society as a whole. More particularly, the appropriate goal of corporate law is to advance the aggregate welfare of a firm's shareholders, employees, suppliers, and customers without undue sacrifice - and, if possible,
} 
principais. Primeiro, exigir dos administradores da sociedade anônima que enderecem a interesses alheios aos dos acionistas da companhia gerida resultaria na perda de eficiência da atividade por ela realizada e, segundo, a maximização do bem-estar gerado pela sociedade anônima, além de benéfica a seus investidores, favorece a todos os seus participantes, sejam-lhe diretos ou não: "a successful firm provides jobs for workers and goods and services for consumers $^{, 213}$.

\section{Henry Hassmann e Reinier Kraakman compartilham da posição} apresentada por Frank Easterbrook e Daniel Fischel sobre a real 'função social da companhia' se identificar ao interesse de seus acionistas. Segundo os autores, é especificamente a essa função da companhia que o regulador deve remeter ao prescrever ambos: o bojo estrutural da sociedade anônima e os termos sobre os quais as relações que dela decorrem devem se dar:

"Focusing principally on the maximization of shareholders returns is, in general, the best means by which corporate law can serve the broader goal of advancing overall social welfare. In general, creditors, workers and costumers will consent to deal with a corporation only if they expect to be better off themselves as a result. Consequently, the corporation - and, in particular, its shareholders - has a direct pecuniary interest in making

with benefit to third parties such as local communities and beneficiaries of the natural environment. This is what economists would characterize as the pursuit of overall social efficiency". HANSMANN, Henry; KRAAKMAN, Reinier. Op. cit., p. 18. "Como uma questão normativa, o objetivo final do direito societário - tal como de qualquer outra área do direito - é o de, presumivelmente, atender aos interesses da sociedade como um todo. Mais especificamente, o objetivo apropriado do direito societário é o de propiciar a geração de bem-estar social dos acionistas, empregados, fornecedores e consumidores da companhia, sem sacrifício injustificado - e, se possível, em benefício de terceiros, tais como comunidades locais e beneficiários do meio ambiente. Isso é o que economistas caracterizam como a busca pela eficiência social da companhia". Compreendida a posição dos autores sobre a natureza dos deveres dos administradores da sociedade anônima frente aos acionistas, à luz da busca pela eficiência em seu exercício, Kenneth Clarkson esclarece: "Ordinarily, corporate officers and other employees owe no direct duty to individual stockholders. Their duty is to the corporation as a whole. A director, however, is in a fiduciary relationship with the corporation and therefore serves the interests of the shareholders in general". CLARKSON, Kenneth W. et. al. Op. cit., p. 792. "Normalmente, os administradores da companhia não possuem qualquer dever direto aos acionistas individualmente considerados. O seu dever é frente à companhia como um todo. Um diretor, em seu lugar, encontra-se numa relação de fidúcia com a companhia e, assim, serve genericamente aos interesses dos acionistas" Tradução livre.

${ }^{213}$ EASTERBROOK, Frank H.; FISCHEL, Daniel R.. Op. cit., p. 38. "Uma empresa bem-sucedida proporciona empregos para trabalhadores e bens e serviços para consumidores" Tradução livre. 
sure that corporate transactions are beneficial, not just to the shareholders, but to all the parties who deal with the firm,"214.

Compreende-se que, à luz da análise funcional do direito societário, o principal objetivo do regulador é maximizar o valor atribuído aos acionistas, como resultado da atividade econômica desenvolvida pela companhia. Sendo assim, a busca contínua por lucro, através da livre competição entre os agentes econômicos é a real 'função social' da sociedade anônima: "The shareholder value is the proper object of corporate law"215.

Sintetizam-se as posições na sociedade anônima. Evidencia-se, assim, o conflito.

Apresentados os pressupostos metodológicos da análise funcional do direito, passa-se ao estudo das estratégias de que o legislador pode se valer para estruturar as relações da companhia. Propor a releitura do direito societário à luz dos problemas de agência inerentes à estrutura da sociedade anônima é o próximo desafio a que se atém a seguir.

\subsection{A abordagem principal-agente: estratégias regulatórias e de governança na sociedade anônima}

"The need for effective corporate governance arises in large corporations because corporate ownership (by shareholders) is separated from corporate control (by officers and managers). In real world, officers and managers are tempted to advance their own interests, even when such interests conflict with those of the shareholders" ${ }^{, 16}$ (Clarkson, 2006).

\footnotetext{
214 HANSMANN, Henry; KRAAKMAN, Reinier. Op. cit., p. 18. "Focar-se principalmente na maximização do retorno aos acionistas é a melhor maneira pela qual a companhia pode servir ao objetivo mais amplo de avançar o bem-estar social. Genericamente, credores, empregados e consumidores somente consentirão em negociar com a companhia caso esperem, como resultado, beneficiar-se. Conseqüentemente, a companhia e, mais especificamente, os acionistas, possuem interesse pecuniário direto de que as operações da companhia sejam benéficas, não só aos acionistas, como também a todas as partes que transacionam com a sociedade anônima" Tradução livre.

215 Ibid. p. 18. "O valor atribuído aos acionistas é o objetivo apropriado do direito societário". Tradução livre.

${ }^{216}$ CLARKSON, Kenneth W. et. al. Op. cit., p. 838. "A necessidade de uma governança corporativa efetiva em grandes companhias existe na medida em que a propriedade da sociedade anônima (dos
} 
A utilização de instrumentos teóricos concebidos para a análise da influência que incentivos exercem sobre a conduta humana e, em especial, ao estudo de situações em que o bem-estar de um agente econômico depende do comportamento de outro, auxilia na compreensão das diversas relações que se desenvolvem em torno da sociedade anônima.

O fundamento para os denominados 'problemas de agência' existentes na companhia reside na própria natureza da estrutura societária, ou na faculdade que a contratação da sociedade anônima atribui a seus constituintes. Conforme se discutiu na primeira parte deste capítulo, permitir aos acionistas delegar a gestão e a realização do objeto da sociedade anônima àqueles que consideram capazes de lhes atribuir melhores resultados levou tanto à popularização da estrutura relacional-contratual em que consiste a companhia, como evidenciou as perplexidades inerentes à sua estrutura e funcionamento.

Compreendida o elemento ‘administrativo' como essencial à sociedade anônima, dentre os vieses que se pode adotar no estudo das atividades fundamentais do exercício da companhia, opta-se por se analisar as operações da transferência de controle na companhia à luz do relacionamento entre os seus participantes. Aqui, destaca-se a leitura propiciada pelo instrumental decorrente da acepção de 'agência' e de sua aplicação no direito societário e que remete à percepção de que a teia de relações que compõem a companhia refere-se diretamente à natureza conceitual de 'agência', no sentido que lhe é mais próprio.

Em sua acepção ampla, a 'agência' ${ }^{217}$ ocorre quando o bem-estar de um primeiro, o principal, depende do comportamento de um segundo, o agente ${ }^{218}$.

acionistas) encontra-se dissociada do controle (de titularidade de diretores e conselheiros de administração). No mundo real, diretores e conselheiros são tentados a perseguir os seus próprios interesses, mesmo quando em conflito com os dos acionistas" Tradução livre.

${ }^{217}$ CLARKSON, Kenneth W. et. al.. Op. cit., p. 635. 
Por sua vez, os problemas ou conflitos de agência referem-se às hipóteses em que é racional ao agente adotar aquilo que melhor lhe aprouver ${ }^{219}$, muitas vezes em detrimento do melhor interesse do principal em cujo nome atua. Assim, a questão central reside em se encontrar meios de se induzir o agente a agir sempre no melhor interesse de seu principal ou, em outras palavras, de se mitigar ou reduzir os custos de agência.

Perfeito exemplo de relação jurídica compreensível como de agência é o negócio jurídico de mandato. Nesse, o mandante (principal) outorga ao mandatário (agente) poderes para que pratique atos ou administre interesses em seu nome e no escopo das prerrogativas que lhe foram conferidas ${ }^{220}$. No âmbito da sociedade anônima, Henry Hassmann e Reinier Kraakman destacam três relações que envolvem problemas decorrentes da 'agência' em seu exercício: a primeira, entre os proprietários da companhia, ou os seus acionistas (principais), e os administradores a quem contratam para gerir seus interesses (agentes). A segunda envolvendo os acionistas controladores (agentes) e os demais acionistas da companhia (principais); e a terceira, entre a própria companhia e suas partes constituintes, tais como seus acionistas, (agentes), e as partes que contratam com a sociedade anônima, ou seus credores, empregados e consumidores, (principais) ${ }^{221}$. Numa acepção mais ampla de 'agência', é possível observar seus conflitos típicos em sua terceira

\footnotetext{
${ }^{218}$ Assim define e explica Michael Parkin: "The principal-agent problem is the problem of devising compensation rules that induce an agent to act in the best interest of a principal. For example, the stockholders of Enron are principals and the firm's managers are agents. The stockholders (the principals) must induce the managers (agents) to act in the stockholders' best interest". PARKIN. Michael. Op. cit., p. 202. "O problema entre agente e principal reside na formulação de regras de compensação que induzam o agente a agir no melhor interesse de seu principal. Por exemplo, os acionistas da Enron são os principais e os administradores da companhia, seus agentes. Os acionistas (principais) devem induzir os administradores (agentes) a atuar no melhor interesse dos próprios acionistas" Tradução livre.

${ }^{219}$ HANSMANN, Henry; KRAAKMAN, Reinier. Op. cit., p. 21.

${ }^{220}$ Assim define o negócio jurídico de mandato a primeira parte do art. 653 do Código Civil Brasileiro: "Opera-se o mandato quando alguém recebe de outrem poderes para, em seu nome, praticar atos ou administrar interesses".

${ }^{221}$ HANSMANN, Henry; KRAAKMAN, Reinier. Op. cit., p. 22.
} 
categoria proposta pelos autores, de modo a incluir a sociedade percebida como um todo na qualidade de principal, cujo bem-estar depende da forma como a sociedade anônima (agente) desenvolve o seu objeto.

Com efeito, a adoção do instrumental propiciado pelo conceito de agência à realidade da sociedade anônima não é unânime na doutrina. A título de exemplo, Kenneth Clarkson não observa, na relação entre administradores e acionistas da companhia e que é tratada por Henry Hassmann e Reinier Kraakman como a primeira modalidade da relação principal-agente a que se referem como origem dos problemas de agência decorrentes da sociedade anônima, os elementos imprescindíveis à sua qualificação como tal. Justifica o autor:

"Directors are sometimes inappropriately characterized as agents because they act on behalf of the corporation. No individual director, however, can act as an agent to bind the corporation; and as a group, directors collectively control the corporation in a way that no agent is able to control a principal ${ }^{222}$.

A posição de Kenneth Clarkson, ao adotar o conceito de 'agência' em seu sentido estrito, para negar-lhe aplicação no bojo das relações entre administradores e acionistas da companhia, é particularmente útil ao estudo da legitimidade da adoção de estratégias de defesa pelos administradores da sociedade anônima, diante de uma oferta pública hostil à aquisição do controle e que, muitas vezes, conforme se discute no final do capítulo 4 seguinte deste estudo, ocorre em potencial conflito de interesses aos dos acionistas da companhia. De todo modo, a utilização do sentido de 'problemas de agência', de que aqui se vale para o estudo das relações decorrentes da transferência de controle na sociedade anônima, reside em sua funcionalidade instrumental,

\footnotetext{
${ }^{222}$ CLARKSON, Kenneth W. et. al. Op. cit., p. 786. "Algumas vezes, diretores são impropriamente caracterizados como agentes, por agirem em nome da companhia. Entretanto, nenhum diretor individualmente é capaz de agir como um agente e obrigar a companhia; e, como um grupo, diretores controlam coletivamente a companhia, de modo que nenhum agente seja capaz de controlar o principal” Tradução livre.
} 
pois auxilia na compreensão da natureza destas relações e, mais especificamente, dos fundamentos à sua regulação.

Conforme demonstra a teoria econômica ao tratar dos incentivos que o agente possui em se distanciar do interesse do principal, em busca de seus próprios, e que se referem aos custos de agência, a mera utilização de comandos por parte do principal não é capaz de solucionar os problemas ou conflitos decorrentes da agência. Primeiro, por ser comum que o agente disponha de um nível de informação melhor e mais elevado que o do principal para a prática dos atos para os quais foi indicado (e por isso pode ter sido escolhido para em nome desse atuar), e, segundo, pelos potenciais conflitos que podem surgir entre os interesses do agente e do principal. Tais conflitos adquirem especial relevo quando os estímulos do agente para se afastar do melhor interesse de seu principal e em seu benefício são imediatos. Explica Michael Parkin:

"Issuing commands does not address the principal-agent problem. In most firms, the shareholders can't monitor the managers and often the managers can't monitor the workers. Each principal must create incentives that induce each agent to work in the interests of the principal $^{, 223}$.

Evidencia-se, assim, a dificuldade em, integralmente e de forma infalível, garantir-se a coincidência entre o melhor interesse do principal e a conduta do agente. Disto resultam perdas relacionadas tanto ao desempenho do agente quanto às situações em que o mesmo atribua a si algo que originariamente caberia ao principal. Também se pode inferir que, da expectativa do principal sobre ambos esses desvios daquilo que seria ter o seu melhor interesse atendido pelo agente e na qual se funda a relação de agência, resulta o menor benefício marginal respectivo à atuação do agente que o

\footnotetext{
${ }^{223}$ PARKIN. Michael. Op. cit., p. 202. "Dar ordens não resolve o problema entre agentes e principais. Em grande parte das companhias, acionistas não são capazes de monitorar os administradores e, muitas vezes, administradores não conseguem monitorar os empregados. Cada principal deve criar incentivos que induzam todo agente a atuar no interesse do principal” Tradução Livre.
} 
principal apresentará, bem como à conseqüente menor remuneração que estará disposto a atribuir ao agente. O que, em seu lugar, o estimulará a buscar o seu próprio benefício, muitas vezes em detrimento do melhor interesse do principal, em violação ao dever de fidúcia discutido no item 3.3 deste ensaio. Não obstante, as possibilidades de distanciamento da conduta do agente do interesse do principal o induzem ao monitoramento daquele e de, assim, incorrer nos custos a ele relativos. Mais ainda, estes custos elevam-se tão maiores sejam os valores econômicos respectivos à relação entre agente e principal, tendo em vista que, em tais casos, maior será o estímulo ao desvio do agente, como o será a expectativa do principal, de que este desvio ocorrerá e, diante disso, maior o seu incentivo para fiscalizar a atuação do agente. Conseqüentemente, estes custos reduzem ainda mais o valor marginal da atuação do agente e, assim, a sua retribuição pela função que exerce, o que, em contrapartida, o incentiva a, ainda mais, individualmente e em seu melhor proveito, buscar aferir resultados positivos da relação de agência. Isso, novamente, mesmo que em detrimento dos interesses do principal. Em síntese, os problemas de agência referem-se a ineficiências resultantes de estímulos e expectativas que os agentes econômicos possuem em situações em que o benefício de um dependa do comportamento de outro e cujas hipóteses correspondentes consistem em um verdadeiro 'paradoxo de agência'.

Conclui-se, portanto, que, à luz dos conflitos de agência e diante do paradoxo existente sobre o comportamento e expectativas de agentes e principais, é imprescindível que se regule as relações jurídicas em que se percebam características tais que se remetam à natureza típica de 'agência', a fim de que se enderece a ineficiência decorrente de tais relações ${ }^{224}$.

\footnotetext{
${ }^{224}$ Assim explicam Henry Hansmann e Reinier Kraakman: "This means, in turn, that the value of the agent's performance to the principal will be reduced, either directly or because, to assure the quality of the agent's performance, the principal must engage in costly monitoring of the agent. The greater
} 
É importante notar que, da enunciação tríplice proposta por Henry Hassmann e Reinier Kraakman sobre os problemas de agência decorrentes da sociedade anônima, se extrai a atipicidade das posições que 'agentes' e 'principais' ocupam em suas interações, ou que as mesmas não se confundem com a qualificação dos participantes na companhia, mas se referem à sua posição numa dada uma relação jurídica. Assim, muito embora os acionistas possam ser genericamente observados como principais frente aos administradores (primeira dimensão de agência proposta pelos autores na sociedade anônima), aqueles que compõem o bloco de controle seriam caracterizáveis em suas relações com os demais acionistas da companhia como agentes de acionistas minoritários e preferenciais (segunda dimensão de agência proposta por Henry Hassmann e Reinier Kraakman). Mais ainda, todos os acionistas com direito de voto seriam consideráveis como agentes daqueles que não o possuem ou que estejam impedidos de exercê-lo numa determinada deliberação. A acepção de 'agência' a que se referem Henry Hassmann e Reinier Kraakman e adotada no presente estudo para a análise das relações decorrentes da transferência de controle na sociedade anônima é de instrumento metodológico adequado à compreensão das relações jurídicas da sociedade anônima e de seus participantes, e não à identificação, ex-ante, das posições de agentes e principais no bojo da companhia.

the complexity of the tasks undertaken by the agent, and the greater discretion the agent must be given, the larger these 'agency costs' are likely to be". HANSMANN, Henry; KRAAKMAN, Reinier. Op. cit., p 22. "Isso significa, em seu lugar, que o valor que o principal atribuirá ao desempenho do agente será reduzido, seja diretamente ou porque, para se assegurar da qualidade desse desempenho, o principal deverá incorrer em custos relacionados ao monitoramento do agente. Tão maior a complexidade dos deveres a serem executados pelo agente, quanto maior a discrição que lhe deverá ser conferida e maiores os 'custos da agência' tenderem a ser" Tradução livre. Porém, além da estrita relação que os autores propõem ao menor valor atribuído pelo agente à performance do principal como consequiência dos custos de monitoriamento, os ditos 'custos de agência' devem ser entendidos como correspondentes, também, à menor expectativa marginal dos benefícios do principal sobre a atuação do agente. Os custos de agência não se referem, portanto, somente aos custos em si relacionados à atuação do agente, mas sim também à menor expectativa marginal do valor da atuação do agente e que, por conseqüência, resulta na menor remuneração que o principal estará disposto a lhe atribuir. Reconhecese o paradoxo existente na relação de agência. 
Feitas tais considerações a respeito da natureza dos conflitos ou problemas de agência na sociedade anônima, procede-se à categorização dita 'funcional' dos instrumentos que integram o direito societário: por centrar-se na tutela da eficiência das relações que se desenvolvem em torno da companhia, conforme destacado ao longo das três primeiras etapas deste capítulo $^{225}$. Segundo a classificação proposta pelos autores dos remédios disponíveis ao regulador, com o propósito de se reduzir os custos decorrentes dos problemas de agência, são duas as categorias que compõem as estratégias integrantes do direito societário. As estratégias regulatórias da sociedade anônima são, em síntese, aquelas que prescrevem os termos substanciais das relações entre agentes e principais, enquanto as de governança ${ }^{226}$ relacionamse à estrutura em si da sociedade anônima e endereçam indiretamente ao relacionamento entre agentes e principais da companhia. Assim apresentamnas Henry Hassman e Reinier Kraakman:

"Regulatory strategies are prescriptive; they dictate the substantive terms that govern either the content of the agent-principal relationship, or the formation or dissolution of that relationship. By contrast, governance strategies build on the elements of hierarchy and dependency that commonly characterize agency relationship; they attempt to protect principals indirectly, either by enhancing their power or by molding the incentive of their agents ${ }^{, 227}$.

\footnotetext{
${ }^{225}$ HANSMANN, Henry; KRAAKMAN, Reinier. Op. cit., p. 22.

${ }^{226}$ É importante notar que o conceito que os autores atribuem em seu classificação proposta às estratégias ditas de governança, e em contraposição às regulatórias das quais se vale para estruturar os pressupostos fundamentais à leitura funcional das relações societárias é distinto da acepção de 'governança corporativa' proposta pela Organização para a Cooperação e Desenvolvimento Econômico das Nações Unidas:"Corporate governance is the system by which business corporations are directed and controlled. The corporate governance structure specifies the distribution of rights and responsibilities among different participants in the corporation, such as the board of directors, managers, shareholders, and other stakeholders, and spells out the rules and procedures for making decisions on corporate affairs". CLARKSON, Kenneth W. et. al. Op. cit., p. 835. "A governança corporativa é um sistema através do qual sociedades empresárias são dirigidas e controladas. A estrutura da governança corporativa delineia a distribuição de direitos e responsabilidades entre os diferentes participantes da companhia, tais como sua diretoria, administradores, acionistas e outros participantes, e se refere às regras e procedimentos para a tomada de decisão na sociedade" Tradução livre.

227 HANSMANN, Henry; KRAAKMAN, Reinier. Op. cit., p. 23. "Estratégias regulatórias são prescritivas: ditam os termos substanciais que regem o conteúdo das relações entre agentes e principais, ou a formação ou dissolução dessas relações. Em seu lugar, estratégias de governança
} 
Em seu lugar, a subclassificação das estratégias regulatórias e de governança em suas diversas espécies, à luz das características de seu objeto e do momento de seu exercício por agentes e principais, ou de verificação da adequação e juridicidade do comportamento adotado pelos agentes no desempenho de suas funções, auxilia-nos na compreensão da natureza das relações jurídicas compreendidas no escopo do direito societário. Em primeiro lugar, é importante notar que cada um dos cinco pares que integram as estratégias que o compõem relaciona-se ao momento de constatação de seu atendimento pelo agente e em favor de seus respectivos principais. A título exemplificativo, enquanto as regras em sentido estrito (rules), como espécie do par da estratégia regulatória de 'constrangimentos impostos aos agentes', são prescrições ex-ante do regulador sobre o comportamento a ser observado pelos administradores da companhia, a previsão genérica de padrões (standards), a segunda espécie que integra o referido par de estratégias, mediante a utilização de termos indeterminados e conforme ilustrativamente se discutiu no item 3.3 deste ensaio no que tange ao conceito, extensão e fundamentos do 'dever de fidúcia' na sociedade anônima, permite a constatação, ex-post, da juridicidade dos atos de administradores e acionistas controladores frente aos demais acionistas da companhia, seus principais.

Assim, diante do estudo das dez espécies de estratégias apresentadas a seguir e que integram o escopo estrutural proposto por Henry Hassmann e Reinier Kraakman, torna-se possível analisar criticamente a regulação das diversas dimensões da sociedade anônima, muito embora e de acordo com o objeto do presente estudo concentre-se na análise das relações decorrentes da transferência de seu controle. Conforme preceituam os autores, através do

referem-se aos elementos hierárquicos ou de dependência que, comumente, caracterizam as relações ditas de 'agência'. Estas buscam proteger indiretamente os principais, seja através do fortalecimento de seu poder na companhia, ou moldando os incentivos de agentes [para que ajam em conformidade aos interesses de seus principais]" Tradução livre. 
instrumental metodológico propiciado por esta análise 'funcional', busca-se reduzir os custos de agência na sociedade anônima de acordo com o princípio da eficiência que, conforme se discutiu nos dois itens anteriores deste estudo, deve orientar o regulador na concepção dos termos fundamentais da estrutura e do exercício da companhia.

A primeira categoria proposta de estratégias, referente aos instrumentos ditos regulatórios, subdivide-se, no par composto pelos 'constrangimentos impostos aos agentes', conforme apresentado, e pelos ‘termos de afiliação' da sociedade anônima. Enquanto os primeiros referem-se à prescrição de regras e padrões que devem ser atendidos pelos agentes em favor de seus respectivos principais $^{228}$, os termos de afiliação tratam especificamente das condições de entrada e saída dos acionistas na sociedade anônima ${ }^{229}$.

Como observado, as regras prescrevem (ex-ante) os exatos comportamentos que devem ser observados pelos agentes no exercício de suas funções e, portanto, têm aplicação limitada diante da complexidade e multiplicidade inerentes à vida da sociedade anônima. Já os padrões, embora também prescrevam deveres aos agentes no exercício de suas atribuições, o fazem mais amplamente, de modo a, num escopo mais extenso, possibilitar a apreciação ex-post da juridicidade do comportamento adotado pelo agente em questão. Diante da 'inevitabilidade do inesperado’, discutida no item 3.2 deste estudo, e da conseqüente impossibilidade em se antever tanto todos os atos e

\footnotetext{
${ }^{228}$ Henry Hansmann e Reinier Kraakman destacam a utilização das estratégias regulatórias, em seu par composto pelos constrangimentos impostos ao agentes, na positivação do direito societário: "The most familiar pair of regulatory strategies constrains agents by commanding them not to make decisions, or undertake transactions, that would harm the interests of their principals. Lawmakers can frame such constrains as rules, which require or prohibit specific behaviors, or as general standards, which leave the precise determination of compliance to adjudicators after the fact". Ibid. p. 23. "O par mais familiar de estratégias regulatórias constrange os agentes, ordenando-os a não tomar determinadas decisões ou realizar operações, que contrariem os interesses de seus principais. Legisladores podem positivar tais constrangimentos como regras, que prescrevem ou proíbem determinados comportamentos, ou como padrões genéricos, que permitem a determinação específica de seu cumprimento pelos agentes aos julgadores e apos o fato" Tradução livre.

${ }^{229}$ Ibid. p. 24.
} 
comportamentos que compõem a existência da sociedade anônima, bem como a sua juridicidade, ambos, regras e padrões, complementam-se: como prescrições endereçadas aos agentes para agir em favor de seus principais, de modo a se permitir a redução dos custos conseqüentes de suas relações.

Exemplos ilustrativos de ambas as espécies de estratégias regulatórias em seu primeiro par, ou que representem constrangimentos impostos aos agentes mediante a prescrição de regras e padrões, respectivamente, são os enunciados referentes à obrigatoriedade de instauração e comunicação aos acionistas da assembléia geral ordinária anual na sociedade anônima e ao dever de lealdade do acionista controlador frente aos demais acionistas, conforme os artigos 123 e 116 da Lei ${ }^{\circ} 6.404 / 76^{230}$.

Conforme enunciado, os termos de afiliação subdividem-se em termos de entrada e de saída da sociedade anônima. Sua importância, como estratégia regulatória ex-ante do comportamento prescrito aos agentes da companhia, refere-se ao nível e à qualidade de informação que deve ser prestada pelos administradores da sociedade anônima ao mercado. Assim, conforme se discutiu nas primeiras três partes deste capítulo, possibilita-se que os agentes econômicos decidam, fundamentadamente, participar ou não da sociedade anônima $^{231}$. Conforme discutido, destaca-se que a tutela da informação no mercado de valores mobiliários possui a segunda função central de permitir que, de acordo com as condições de oferta e demanda, o preço dos valores emitidos pela sociedade anônima reflitam o seu real valor, tal como atribuído

\footnotetext{
${ }^{230}$ Dispõem os artigos 123 e 116, da Lei $n^{\circ}$ 6.404/76, respectivamente: "Compete ao conselho de administração, se houver, ou aos diretores, observado o disposto no estatuto, convocar a assembléiageral" ; e "O acionista controlador deve usar o poder com o fim de fazer a companhia realizar o seu objeto e cumprir sua função social, e tem deveres e responsabilidades para com os demais acionistas da empresa, os que nela trabalham e para com a comunidade em que atua, cujos direitos e interesses deve lealmente respeitar e atender".

${ }^{231}$ Ibid. p. $24 / 25$.
} 
pelo mercado e à luz das reais circunstâncias que permeiam o exercício e o funcionamento da companhia ${ }^{232}$.

Por sua vez, os direitos de saída são compreendidos por Henry Hassmann e Reinier Kraakman como espécie de estratégia regulatória dita expost do comportamento dos agentes na sociedade anônima. Preliminarmente, os direitos de saída são ilustrados pelos autores como dois - genérica ou restritamente conferidos aos acionistas: o de transferir as ações de que sejam titulares e o de se retirar da companhia em determinadas circunstâncias ${ }^{233}$. O estudo dos 'direitos de saída' em espécie, tal como atribuídos por diversos ordenamentos jurídicos aos acionistas da sociedade anônima diante de determinadas situações e, sobretudo, na transferência do controle acionário. Nos dois capítulos subseqüentes deste estudo, analisa-se tanto como a atribuição a determinadas classes de acionistas direitos ditos 'de saída' representa um instrumento de tutela de interesses dos minoritários, como, ao mesmo tempo, restringe as hipóteses de transferência de controle na sociedade anônima, tal como o faz permitir que sejam adotadas estratégias de defesa à oferta pública hostil à sua aquisição. Em seus fundamentos, ambos, os direitos de saída e as estratégias de defesa à tomada de controle, aproximam-se, pois

\footnotetext{
${ }^{232}$ EASTERBROOK, Frank H.; FISCHEL, Daniel R.. Op. cit., p. 15 e ss.

${ }^{233}$ Henry Hansmann e Reinier Kraakman conceituam os direitos em espécie que integram o par de termos de afiliação na regulação societária como: "The first is the right to withdraw the value of one's investiment. The best example of such a right in corporate law is the technique, employed in some jurisdictions, of awarding an appraisal right to shareholders who dissent from certain major transactions such as mergers (...) The second type of exit right is the right of transfer - the right to sell shares in the market - which is of obvious importance to public shareholders. (Recall that transferability is a core characteristic of the corporate form)". HANSMANN, Henry; KRAAKMAN, Reinier. Op. cit., p, 25. "O primeiro é o direito de retirada do valor investido. Seu melhor exemplo é a técnica adotada em alguns ordenamentos, de conceder direito de retirada aos acionistas dissidentes de certas deliberações, tais como incorporações. A segunda espécie de direitos de saída é de transferir - o direito de vender ações no mercado secundário - e que é de importância óbvia aos acionistas de companhias abertas. Atente-se para o fato de que a livre transferibilidade de ações é uma característica elementar à estrutura corporativa". Tradução livre. No item 4.3 deste estudo, trata-se da natureza e das conseqüências dos direitos de saída sob uma perspectiva funcional.
} 
elevam os custos relacionados à transferência de controle da sociedade anônima.

A segunda categoria em sentido amplo de instrumentos legais passíveis de serem utilizados para a redução dos custos de agência é composta pelas estratégias de governança. A primeira de suas três modalidades propostas por Henry Hassmann e Reinier Kraakman é o direito conferido aos acionistas de, direta (no caso de diretores) ou indiretamente (com relação aos membros do conselho de administração), indicar os responsáveis pela administração da sociedade anônima ${ }^{234-235}$. Seja através da seleção daqueles que devem orientar os negócios sociais (ex-ante), ou de sua remoção, como expressão da vontade do corpo acionário (ex-post). Compreendido o papel elementar que a delegação e a centralização da administração possuem na sociedade anônima, deduz-se a relevância em se atribuir aos acionistas da companhia, na qualidade de principais, a capacidade de indicar os seus agentes, bem como de destituí-los de seus 'offices', como expressão da vontade social, prerrogativa essa cujos termos são fundamentais à compreensão do exercício do controle na sociedade anônima ${ }^{236}$.

\footnotetext{
${ }^{234}$ No ordenamento jurídico brasileiro, o direito de indicação, por sua própria natureza, é uma prerrogativa conferida somente aos acionistas que possuem o direito de voto na sociedade anônima, tal como o par de estratégias de governança relacionado aos direitos de decisão na companhia e analisada em seguida.

${ }^{235}$ As menções à indicação 'direta' e 'indireta' nas hipóteses da prerrogativa dos acionistas com direito de voto de nomear os conselheiros de administração e diretores da companhia referem-se às formas deexercício dessa estratégia de governança tal qual positivada na Lei das Sociedades por Ações. Conforme seus artigos 142 e 138, respectivamente: "Compete ao conselho de administração: II - eleger e destituir os diretores da companhia e fixar-lhes as atribuições, observado o que a respeito dispuser o estatuto" e "nos 4 (quatro) primeiros meses seguintes ao término do exercício social, deverá haver 1 (uma) assembléia-geral para: eleger os administradores e os membros do conselho fiscal, quando for o caso".

${ }^{236}$ Assim sustentam Henry Hansmann e Reinier Kraakman: "Given the central role of delegated management in the corporate form, it is no surprise that appointment rights - the power to select or remove directors (or other managers) - are key strategies for controlling the enterprise". HANSMANN, Henry; KRAAKMAN, Reinier. Op. cit., p. 26. "Diante do papel central da delegação da gestão do objeto social à estrutura corporativa, não surpreende o fato de que os direitos de indicação - ou o poder de selecionar e remover diretores e outros administradores - são estratégias centrais para o exercício do controle da companhia" Tradução livre. De acordo com a classificação proposta pelos
} 
O segundo par que integra as estratégias de governança no direito societário relaciona-se à capacidade atribuída aos acionistas (principais) de iniciarem (ex-ante), ou de ratificarem (ex-post) determinadas decisões relacionadas ao exercício da companhia ${ }^{237}$. No ordenamento brasileiro, exemplo ilustrativo de ambas as estratégias de governabilidade é a faculdade conferida à assembléia geral de deliberar a redução do capital social. Caso a proposta de redução do capital social seja de iniciativa dos administradores, observa-se que, conforme dispõe o artigo 173 , em seu $\S 1^{\circ}$, da Lei $n^{\circ} 6.404 / 76$, a matéria deve ser submetida à deliberação da assembléia geral para que, caso a julgue oportuna, assim a ratifique ${ }^{238}$.

Segundo a classificação de Henry Hassmann e Reinier Kraakman, o último par que compõe as estratégias de governança na sociedade anônima refere-se aos incentivos que se pode atribuir ao agente em realizar o melhor interesse do principal. A discussão de seus fundamentos é elementar, tal como a das regras e padrões, para o estudo dos termos em que são utilizáveis as estratégias de defesa pela administração da sociedade anônima, e que é objeto da última parte do capítulo 4 seguinte desse estudo.

\footnotetext{
autores, a proximidade entre essa estratégia de governança e o segundo par de estratégias regulatórias das relações decorrentes da sociedade anônima, composto pelas regras (rules) e padrões (standards) frente ao exercício de controle, é evidenciada no estudo realizado no item 4.4 deste ensaio, quando se discute os fundamentos da regulamentação consubstanciada na City que integra o ordenamento jurídico britânico diante de uma oferta pública à aquisição do controle acionário. Conforme se discute a seguir, tanto os padrões (standard) prescritos aos administradores diante de uma oferta hostil de tomada de controle, como a faculdade conferida aos acionistas de alterar a composição da administração da companhia, visam a garantir a coincidência dos interesses de agentes e principais no curso de uma oferta pública à aquisição.

${ }^{237}$ Ibid. p. 26.

${ }^{238}$ Dispõem o artigo 173 e parágrafos da Lei $n^{\circ}$ 6.404/76: "A assembléia-geral poderá deliberar a redução do capital social se houver perda, até o montante dos prejuízos acumulados, ou se julgá-lo excessivo. $\S 1^{\circ}$ A proposta de redução do capital social, quando de iniciativa dos administradores, não poderá ser submetida à deliberação da assembléia-geral sem o parecer do conselho fiscal, se em funcionamento. $\S 2^{\circ}$ A partir da deliberação de redução ficarão suspensos os direitos correspondentes às ações cujos certificados tenham sido emitidos, até que sejam apresentados à companhia para substituição".
} 
Como suas modalidades, enquanto estratégia de recompensa são prescritas ex-ante, tais como premiações conferidas aos administradores da companhia, na qualidade de agentes, caso avancem os melhores interesses dos acionistas, seus principais, a estratégia de governança dita trusteeship visa a eliminar os conflitos entre agentes e principais, ao permitir a verificação, $e x$ post, do comportamento dos agentes em atenção aos interesses de seus principais. Isso, à luz dos princípios ético-morais expectáveis nas relações de 'agência', como nas existentes entre acionistas e administradores e, de acordo com o objeto do item 3.3 deste capítulo, refere-se à posição de trustee que estes exercem no exercício de suas funções ${ }^{239-240}$.

Henry Hassmann e Reinier Kraakman caracterizam ambas as estratégias de acordo com a natureza econômica ou não dos incentivos atribuídos aos agentes para atuarem no melhor interesse de seus principais ${ }^{241}$. Em atenção às estratégias de recompensa, Michael Parkin as define como um dos meios inicialmente adotáveis para se reduzir os custos decorrentes dos problemas entre principal e agente: "three ways of attempting to cope with the principal-agent problem are: ownership; incentive pay; and long-term contracts ${ }^{242}$.

Com efeito, a sociedade anônima em sua contemporaneidade demonstrou os riscos inerentes à adoção em excesso de instrumentos de recompensa aos administradores. Casos recentes evidenciam que a tentativa em se buscar eliminar os conflitos de agência, através da utilização de estímulos remuneratórios elevados aos agentes, a fim de se buscar garantir a coincidência integral de seus interesses aos dos principais, pode se mostrar

\footnotetext{
${ }^{239}$ BAYNE, David Cowan. Op. cit., p. 36/37.

${ }^{240}$ HANSMANN, Henry; KRAAKMAN, Reinier. Op. cit., p. 26.

${ }^{241}$ PARKIN, Michael Op. cit., p. 202.

${ }^{242}$ Ibid. p. 202. "Três maneiras de endereçar aos problemas de agência são: propriedade, prêmios e contratos de longa-duração" Tradução livre.
} 
como um típico exemplo de um remédio cujos efeitos colaterais adversos podem superar em muito os da patologia que se pretende curar, quando não acabam matando o próprio paciente. Portanto, restam aos reguladores e participantes da sociedade anônima as demais estratégias regulatórias e de governança que podem ser utilizadas, a fim de se reduzir os custos de agência e de, assim, se otimizar os resultados da companhia.

Compreendidos os fundamentos da análise funcional do direito, seguese à delimitação do escopo das operações de transferência de controle na sociedade anônima e ao estudo de seus elementos. 


\title{
Capítulo 4 - A análise funcional da transferência de controle
} na sociedade anônima: fundamentos

\author{
"At the helm of every corporation, without exception, \\ stands one man or group of men holding the ultimate direction of \\ all corporate activity. This is an intrinsic necessity. At every minute \\ of time, someone, anyone, must be in charge of the entity. To \\ identify with certainty the specific person in control may at times be \\ difficult or even impossible. Control may shift often, be tenuous or \\ fragile, but control, by inherent logic, must ineluctably be present \\ in every business corporation"243 (David Cowan Bayne, 1987).
}

\subsection{As operações de transferência de controle na sociedade anônima segundo Davies e Hopt: escopo}

"Whoever sells the majority block of stock of a corporation has the duty to it and the shareholders to fully identify the purchaser in order to discover his background and the use to which the control stock is to be put in its management"244 (Estate of Hooper v. Virgin Islands, 3d Circuit, 1970).

As operações de transferência de controle na sociedade anônima podem ser estrita e preliminarmente compreendidas como aquelas em que um adquirente, o agente, busca, através da realização de ofertas aos acionistas da companhia cujo controle deseja obter (a companhia-alvo), em conjunto, seus principais, comprar ações com direito de voto em número suficiente para adquirir o controle da sociedade ${ }^{245} \mathrm{~A}$ característica peculiar à oferta pública de

\footnotetext{
${ }^{243}$ BAYNE. David Cowan, Op. cit., p. 6. "No controle de toda companhia, sem exceção, encontra-se um indivíduo ou um grupo de pessoas que possuem a última palavra sobre os negócios da sociedade. Essa é uma necessidade intrínseca. A todo minuto, alguém, qualquer um, deve estar no controle da companhia. Para identificar especificamente quem é o controlador pode ser algumas vezes difícil ou, até mesmo impossível. O controle pode ser transferido algumas vezes, ser tênuo ou frágil, de todo modo, por uma lógica que é inerente, o controle, inevitavelmente, deve estar presente em toda sociedade empresarial" Tradução livre.

${ }^{244}$ Ap. Ibid. p. 145. "Aquele que aliene o bloco majoritário de ações duma companhia tem o dever frente à sociedade e aos seus acionistas de identificar o adquirente, de modo a divulgar tanto as suas informações individuais, como a utilização que pretenda atribuir ao bloco de controle de ações que adquira" Tradução livre.

${ }^{245}$ Por razões metodológicas, a definição genericamente utilizada refere-se ao conceito de oferta pública de aquisição do controle acionário. É a partir do conceito que lhe atribuem Paul Davies e Klaus Hopt delineado ao longo deste item que melhor se observa a natureza da categoria proposta pelos autores de 'transações de controle' e objeto deste item. Conforme definem Paul Davies e Klaus Hopt: "When a person (the acquirer) attempts, through offers to the company's shareholders, to acquire
} 
tomada de controle, também observada na transferência de controle acionário realizada mediante a sua cessão, e que diferencia ambas as operações de outras que também têm como objeto a transferência do controle na sociedade anônima, é o aparecimento de um terceiro, o adquirente, frente à companhiaalvo e aos acionistas titulares de seu capital social.

De acordo com a classificação concebida à luz dos problemas de agência inerentes às relações societárias discutidos no item 3.4 deste estudo, Paul Davies e Klaus Hopt propõem uma significação restrita ao que conceituam 'transações de controle'. É o surgimento de um terceiro inicialmente estranho à companhia-alvo e aos seus acionistas, bem como dos conflitos de agência daí decorrentes, que diferencia o estudo das ditas 'transações de controle' do de sua transferência decorrente de ações que denominam 'relevantes' à sociedade anônima, pois compreendidas unicamente por relações internas aos participantes da companhia ${ }^{246-247}$.

sufficient voting shares in a company to give it control of that company". DAVIES, Paul; HOPT, Klaus. Op. cit., p. 157. "Quando um indivíduo (o adquirente) tenta, através da realização de ofertas direcionadas aos seus acionistas adquirir ações com direito de voto suficientes à obtenção do controle da companhia-alvo" Tradução livre.

246 Assim explicam os autores: "No doubt, this is a restricted definition of a control transaction: clearly, control may also pass to a new shareholder or set of shareholders as a result of transactions between the company and its shareholders or the investing public (as when companies issues or repurchases shares). However, control transactions involving corporate decisions can be analysed in the same manner as other corporate decisions". Ibid. p. 158 "Sem dúvidas, [a categoria que propomos] é uma definição restrita de transações de controle: de fato, o controle pode ser transferido a outro acionista ou grupo de acionistas como resultado de transações entre a companhia e os seus acionistas ou frente ao público-investidor (assim como quando companhias emitem ou adquirem ações de sua própria emissão). De todo modo, as operações de transferência de controle que envolvam decisões tomadas no bojo da companhia podem ser analisadas da mesma forma que outras decisões da companhia" Tradução livre.

${ }^{247}$ Em seu lugar, Frank Easterbrook e Daniel Fischel atribuem à categoria transações de controle da sociedade anônima um conceito amplo que abarca ambas as operações concebidas por Paul Davies e Klaus Hopt na diferenciação que propõem, segundo a percepção dos conflitos de agência. Como são distintos os problemas entre agente e principal nas operações observadas, Paul Davies e Klaus Hopt as subdividem em duas categorias: as operações de transação de controle em sentido estrito e as ações relevantes à sociedade anônima. A classificação proposta pelos autores é discutida ao longo deste item: Em sua acepção ampla proposta por Frank Easterbrook e Daniel Fischel, as transações de controle relacionam-se à dinâmica típica à atividade desenvolvida pela sociedade anônima. Explicam os autores: "Firms are in motion. They build new plants and enter or retreat from markets. They also change their own structure - setting up new divisions, entering or leaving markets, buying or selling 
As operações ditas 'relevantes' à companhia são conceituadas por Edward Rock, Hideki Kanda e Reinier Kraakman como aquelas cuja deliberação favorável dos acionistas, principais da sociedade anônima, é, por razões pertinentes à dimensão, elevada capacidade deliberativa da assembléia geral sobre a matéria em questão ou pelo eventual conflito de interesses dos administradores, percebida como imprescindível à sua realização ${ }^{248}$. É habitual que o regulador se valha, por razões peculiares a cada uma dessas situações e a fim de reduzir os custos correspondentes aos problemas de agência entre acionistas e administradores da sociedade anônima, do par de estratégias regulatórias de governança correspondente ao direito de decidir atribuído aos acionistas e discutido no item 3.4 deste estudo, facultando-lhes, como principais e titulares do capital social da companhia, tanto iniciar certas deliberações, como ratificá-las ou vetá-las, quando de iniciativa dos seus agentes, os administradores da sociedade anônima. Assim, para a realização de tais operações consideradas 'relevantes' à companhia, exige-se, além da decisão favorável dos administradores da companhia, a concordância de

plants, acquiring or being acquired, increasing and decreasing leverage, going public or private, selling stock or buying it back (...) We call these changes "corporate control transactions"” EASTERBROOK, Frank H.; FISCHEL, Daniel R.. Op. cit., p. 109. "As companhias encontram-se em constante movimento. Constroem plantas e entram e saem dos mercados. Alteram a sua própria estrutura - estabelecendo novas divisões, entrando ou se retirando de mercados, comprando ou alienando plantas, adquirindo ou sendo adquiridas, aumentando, reduzindo, abrindo ou fechando o seu capital, vendendo ações ou adquirindo-as (...) Tratamos estas modificações na companhia como "transações de controle na sociedade anônima"” Tradução livre.

${ }^{248}$ Extensivamente, os autores compreendem na categoria de 'ações relevantes á sociedade anônima' aquelas em que: "Corporate Law seldom limits board discretion unless corporate actions share at least one (and usually three) of the following characteristics: (1) they are large relative to the value of the company;(...), (2) investment-like judgments that shareholders are arguably equipped to make and (3) they create a possible conflict of interests for directors, even if this conflict does not rise to the level of self-dealing transaction". ROCK, Edward. et. al. Significant Corporate Actions. In: KRAAKMAN, Reinier et. al. The Anatomy of Corporate Law: a Comparative and Functional Approach. New York: Oxford University Press. p. 131. O direito societário raramente limita a discricionariedade dos diretores, salvo se as operações da sociedade anônima compartilharem, pelo menos, uma (e normalmente exigem-se três) das seguintes características: (1) serem expressivas em relação ao valor da companhia (...) (2) representarem investimentos tais que os acionistas por meio de seu juízo são discutivelmente capazes de realizar e (3) criarem um possível conflito de interesses para os administradores, mesmo que este conflito não alcance um nível de negociações entre partes relacionadas" Tradução livre. 
determinada parcela do capital votante da sociedade anônima ${ }^{249}$. Conferida à assembléia geral a capacidade de iniciar ou ratificar uma determinação decisão pela natureza, importância de seu objeto ao exercício da sociedade anônima ou pelo eventual interesse de seus participantes, busca-se mitigar os custos de agência que decorreriam da ausência de disposição regulamentar que assim dispusesse ${ }^{250}$.

Paul Davies e Klaus Hopt baseiam-se na premissa de que os problemas de agência que as transações de controle em sentido estrito apresentam e que lhes são peculiares são distintos dos decorrentes de decisões cujo objeto, muito embora seja também a transferência de controle, derivem de relações estritamente internas à sociedade anônima e que, nesse aspecto, se assemelham aos de outras ações ditas 'relevantes' da companhia ${ }^{251-252}$. No

\footnotetext{
${ }^{249}$ No ordenamento jurídico brasileiro, ressalva-se que, no caso de liquidação da sociedade anônima, cuja competência deliberativa é privativa da assembléia gera de acionistas, conforme dispõe o inciso VIII, do artigo 122 da Lei $\mathrm{n}^{\circ}$ 6.404/76, todos os acionistas da companhia possuem direito de voto, em atenção à parcela do capital social de que sejam titulares e independentemente de eventuais restrições ou limitações relativas ao exercício desse direito. Assim prevê o $\S 1^{\circ}$, do art. 213, da lei societária: "Nas assembléias-gerais da companhia em liquidação todas as ações gozam de igual direito de voto, tornando-se ineficazes as restrições ou limitações porventura existentes em relação às ações ordinárias ou preferenciais; cessando o estado de liquidação, restaura-se a eficácia das restrições ou limitações relativas ao direito de voto".

${ }^{250}$ Explicam Paul Davies e Klaus Hopt: "The corporation that is selling all its assets is substantially changing its business position and perhaps its ability to carry out its corporate purposes. For that reason, the corporation whose assets are acquired must obtain approval from both its board of directors and its shareholders" DAVIES, Paul; HOPT, Klaus. Op. cit., p. 162. "A companhia que está vendendo todo os seus ativos está transformando substancialmente a sua posição negocial e, quiçá, abidicando de sua capacidade para desempenhar as suas finalidades corporativas. Por esse motivo, as sociedades cujos bens são adquiridos devem obter aprovação por parte tanto de seus diretores, como de seus acionistas" Tradução livre.

${ }^{251}$ Como exemplo elucidativo proposto por Paul Davies e Klaus Hopt, são distintas as relações oriundas de transações de controle (em sentido estrito) das decorrentes de operações como, por exemplo, de incorporação: "A merger involves corporate decisions, certainly by shareholders and often by the directors as well. Control transactions, by contrast, are effected by private contract between the acquirer and the shareholders individually, with consequent scope for the acquirer to exploit uncertainty on the part of any one shareholder as to what the majority of the shareholders will decide". DAVIES, Paul; HOPT, Klaus. Op. cit., p. 161. Uma incorporação envolve decisões empresariais, certamente pelos acionistas e muitas vezes pelos diretores da companhia. Transações de controle, pelo contrário, são contratadas mediante acertos privados entre o adquirente e os sócios individualmente considerados, com a finalidade de se explorar a insegurança potencial por parte dos acionistas com relação ao que a maioria irá decidir” Tradução livre.
} 
ordenamento jurídico brasileiro, são exemplos de operações ditas 'relevantes’à companhia e que, por essa razão, têm como imprescindível a deliberação da assembléia geral para a sua realização ${ }^{253-254}$ os negócios jurídicos de fusão, aquisição e de incorporação societária, dentre outros listados ao longo do artigo 122 da Lei $\mathrm{n}^{\mathrm{o}} 6.404 / 76^{255}$. Deixa-se, assim, a análise funcional de operações relacionadas à empresa, tais como a alienação de parcela relevante dos ativos da companhia, e estruturais à sociedade anônima deliberadas internamente à companhia, e não, propriamente, da transferência do controle acionário a um terceiro estranho à sociedade, para um outro estudo.

A proximidade das modalidades de transferência de controle deliberadas internamente à sociedade a outras ações relevantes da companhia justifica-se por razões metodológicas. À luz dos problemas de agência respectivos às operações societárias, a decisão por se alterar a titularidade do

\footnotetext{
252 Complementam os autores: "Control may also pass to a new shareholder or set of shareholders as a result of transactions between the company and its shareholders or the investing public (...) However, control transactions involving corporate decisions can be analyzed in the same manner as other corporate decisions". Ibid. p.161. O controle também pode ser transferido a um novo acionista ou grupo de acionistas, como resultado de transações entre companhia e seus acionistas ou com o público investidor (...) No entanto, as modalidades de transferência de que envolvem decisões empresariais podem ser analisadas da mesma maneira que outras decisões empresariais" Tradução livre.

${ }^{253}$ CLARKSON, Kenneth W. et. al. Op. cit., p. 812.

${ }^{254}$ Kenneth Clarkson explica a diferença da natureza da alienação do ativo da companhia vis a vis as operações de transferência de controle ou, em conformidade com a terminologia proposta por Paul Davies e Klaus Hopt e delineada neste item, de transações de controle: "When a corporation acquires all of substantial all of the assets of another corporation by direct purchase, (...) the acquiring corporation - simply extends its ownership and control over more physical assets. Because no change in the legal entity occurs, the acquiring corporation need not obtain shareholder approval of the purchase". CLARKSON. Kenneth W., et. al. Op. cit., p. 811. Quando uma companhia adquire todos os bens substanciais do ativo de uma outra companhia através de sua compra direta (...) a companhia adquirente - simplesmente estende a sua propriedade e controle sobre mais ativos. Porque nenhuma alteração na entidade jurídica ocorre, a companhia adquirente não precisa obter a aprovação dos acionistas para realizar a operação" Tradução livre.

${ }^{255}$ São essas as previstas nos incisos IV, VI, VII e VIII, do dispositivo, que seguem: "Compete privativamente à assembléia-geral: IV - autorizar a emissão de debêntures, ressalvado o disposto no $\S$ $1^{\circ}$, do art. 59, VI - deliberar sobre a avaliação de bens com que o acionista concorrer para a formação do capital social; VII - autorizar a emissão de partes beneficiárias; VIII - deliberar sobre transformação, fusão, incorporação e cisão da companhia, sua dissolução e liquidação, eleger e destituir liquidantes e julgar-lhes as contas; e IX - autorizar os administradores a confessar falência e pedir concordata".
} 
controle deliberada no bojo da sociedade anônima distancia-se, em suas modalidades, do que Paul Davies e Klaus Hopt classificam como as modalidades da transação do controle social, em que figuram um terceiro adquirente. Conforme destaca David Cowan Bayne sobre a relevância do momento de transferência do controle acionário para a sociedade: "At no other time is the total destiny of the entity so completely at stake"256.

Diante da leitura funcional dos problemas de agência existentes nas relações societárias que se propõe realizar, se exclui do escopo do presente estudo a análise das operações, cujo objeto, embora seja a transferência de controle, decorra da deliberação da assembléia geral. Em atenção à classificação proposta por Paul Davies e Klaus Hopt, limita-se, aqui, à análise do que os autores tratam como operações de 'transação de controle', compreendidas como as modalidades de sua transferência a um terceiro. Seja por sua realização voluntária, através da cessão do controle acionário, ou pela sua operação compulsória, na tomada de controle realizada mediante oferta pública de aquisição. No presente estudo, é nesse sentido estrito que lhe atribuem os autores a que se irá referir ao se utilizar a expressão 'transferência de controle na sociedade anônima ${ }^{257}$.

Adotada a terminologia e o escopo propostos por Paul Davies e Klaus Hopt para a análise da transferência de controle da sociedade anônima à luz dos problemas de agência e dos pressupostos da análise funcional da regulamentação societária, prossegue-se, nos itens subseqüentes deste

\footnotetext{
${ }^{256}$ BAYNE, David Cowan. Op. cit., p. 7. "Em nenhum outro momento, o destino da companhia encontra-se tão em jogo" Tradução livre.

257 DAVIES, Paul; HOPT, Klaus. Op. cit., p. 175. É importante ressalvar que as ditas 'escaladas societárias' realizadas por um terceiro são tratadas somente de forma incidental juntamente à oferta pública de aquisição de controle no item 5.2 como categoria de transação de controle. Justifica-se o tratamento em conjunto destas operações, tendo em vista que ambas são características à obtenção do controle acionário de companhias com capital disperso, em que não se destaca, do capital social votante da companhia-alvo, um bloco representativo que, embora não se confunda com o controle, lhe seja correspondente.
} 
capítulo, ao estudo de três dos principais elementos relacionados ao 'valor' correspondente ao controle e à regulação de sua transferência. A discussão sobre a desejabilidade econômico-social da transferência de controle na sociedade anônima, das implicações referentes ao prêmio pelo controle da companhia e dos instrumentos de defesa a uma oferta pública hostil de tomada de controle na sociedade anônima servirá como fundamento ao estudo das espécies de transferência de controle realizado no quinto e último capítulo deste ensaio.

\subsection{A desejabilidade econômico-social da transferência do controle acionário na sociedade anônima}

"Quando se fala em tutela dos interesses dos minoritários e trabalhadores na alienação de controle, quer-se significar ambos os grupos enquanto co-titulares do interesse social. $\mathrm{O}$ interesse dos dois grupos, enquanto tais, pode ser protegido por regras específicas de direito societário e trabalhista após e apesar da alienação de controle. No entanto o seu interesse enquanto cotitulares do interesse social deve ser protegido no momento da aquisição, na medida em que essa ponha em risco a preservação da organização produtiva" ${ }^{, 258}$ (Calixto Salomão Filho, 2005).

Conforme se discutiu nos itens 3.2 e 3.3 deste estudo, de acordo com a análise funcional do direito, a legitimidade de sua vertente societária reside na busca em se otimizar os resultados decorrentes da companhia mediante a regulação de sua estrutura e das relações entre os agentes que a integram. Mais especificamente, da leitura funcional da regulação da estrutura corporativa, propiciada pelo instrumental teórico originado dos ditos 'problemas' ou 'conflitos' de agência, infere-se que o objetivo que o regulador deve ter em vista na estruturação da companhia, como complexo contratualinstitucional, é mitigar os custos de agência entre os seus participantes. Isso, sempre à luz do princípio da eficiência e da busca por se maximizar o bemestar social decorrente da companhia.

${ }^{258}$ COMPARATO, Fábio Konder; FILHO, Calixto Salomão. Op. cit., p. 264. 
A discussão sobre a desejabilidade econômico-social da transferência de controle na sociedade anônima realizada à luz dos problemas de agência remete a esses mesmos fundamentos. Os autores que se propõem a analisar funcionalmente a estrutura do direito societário partem da finalidade instrumental da transferência de controle em suas modalidades, como meio de se permitir a aferição do valor adequado à sociedade anônima. Assim, genericamente, entendem a transferência de controle acionário como fato econômica e socialmente desejável sob um prisma funcional ${ }^{259}$. É essa a posição de Frank Easterbrook e Daniel Fischel:

"Control transactions reflect substantial gains. Sale of a control bloc of stock, for example, allows the buyer to install his own management team, producing any gains available from the new structure. Because such a buyer believes he can manage the assets of a firm more profitably, he is willing to pay a premium over the market price to acquire control ${ }^{260}$.

No entanto, o apreço pela transferência de controle como instrumento maximizador do valor atribuído à companhia não é unânime. Calixto Salomão Filho assim apresenta as premissas em que se baseiam Frank Easterbrook, Daniel Fischel e seguidas por outros autores, cujas raízes remetem aos

\footnotetext{
${ }^{259}$ HANSMANN, Henry; KRAAKMAN, Reinier, Op. cit., p. 18.

260 EASTERBROOK, Frank H.; FISCHEL, Daniel R.. Op. cit., p. 112. "Transações de controle refletem ganhos substanciais. A venda do bloco acionário de controle de uma sociedade, por exemplo, permite ao adquirente indicar os seus próprios administradores, produzindo ganhos decorrentes da nova estrutura. Tendo em vista que o comprador acredita que pode gerir os ativos da companhia mais lucrativamente, estará disposto a pagar um prêmio sobre o valor de mercado da companhia a fim de adquirir o seu controle" Tradução livre. No mesmo sentido compreendem Paul Davies e Klaus Hopt, como se pode inferior da observação que fazem sobre a regulação da transferência de controle nos sistemas jurídicos dos Estados Unidos, Reino Unido, França, Alemanha e Japão: "The first and the negative conclusion is that non of the systems we have studied puts the goal of maximizing the number of takeovers at the centre of their regulatory structures". DAVIES, Paul; HOPT, Klaus. Op. cit., p. 189. "A primeira e negativa conclusão que se chega é que nenhum dos sistemas estudados tem, como finalidade, maximizar o número de tomadas hostis do controle como centro de suas estruturas regulatórias" Tradução livre. Do que se infere a posição dos autores favorável à desejabilidade da transferência do controle como uma das possíveis finalidades a que o regulador pode endereçar na estruturação das relações decorrentes da sociedade anônima.
} 
"pressupostos juspolíticos específicos dos quais parte a Escola de Chicago"261 e que, a esse respeito, identificam-se aos da análise funcional do direito:

"Dentro dos interesses chamados externos [à companhia] menciona-se, quase intuitivamente, o interesse público em geral. Também esse termo merece especificação. Pode-se em primeiro lugar imaginar a existência de um interesse público em geral na manutenção de um livre mercado de aquisições de companhias. Para os defensores dessa linha liberal, todos, acionistas, trabalhadores e investidores, seriam beneficiados pela alocação ótima dos fatores proporcionada pela existência de um livre mercado de participações acionarias" ${ }^{262}$.

Os autores que propõem a leitura econômica das relações societárias defendem que a transferência de controle acionário é capaz de maximizar o valor da sociedade anônima ${ }^{263}$ e, ao assim fazer, otimizar o valor atribuído aos seus acionistas ${ }^{264}$. $\mathrm{O}$ adquirente do controle acionário, disposto a pagar o valor que lhe seja correspondente, ofertará a sua aquisição somente caso se perceba capaz de auferir resultados positivos do exercício do controle na companhia, em comparação aos custos relacionados à operação ${ }^{265}$. De fato, é lógico se esperar que caso o adquirente não entenda a aquisição do controle da sociedade-alvo como lucrativa, preferirá se abster a realizar a operação. Da mesma forma, caso assim não compreendessem os acionistas titulares das ações que compõem o bloco majoritário de controle da companhia e na qualidade de destinatários da oferta por sua transferência se recusariam a aliená-las (no caso de cessão do controle acionário) tal como o fariam, genericamente, os acionistas da companhia-alvo (no caso de oferta pública à aquisição do controle $)^{266}$. Resta, no entanto, discutir a legitimidade e as

\footnotetext{
${ }^{261}$ COMPARATO, Fábio Konder; FILHO, Calixto Salomão. Op. cit., p. 263.

${ }^{262}$ Ibid. p. 263.

${ }^{263}$ EASTERBROOK, Frank H.; FISCHEL, Daniel R.. Op. cit., p. 126.

${ }^{264}$ Assim fundamentam Henry Hansmann e Reinier Kraakman, conforme discutido no item 3.3 deste estudo: "The shareholder value is the proper object of corporate law". HANSMANN, Henry; KRAAKMAN, Reinier, Op. cit., p. 18. "O valor atribuído aos acionistas é o objeto apropriado do direito societário". Tradução livre.

${ }^{265}$ EASTERBROOK, Frank H.; FISCHEL, Daniel R.. Op. cit., p. 112.

${ }^{266}$ Com efeito, conforme se discute adiante, na hipótese de oferta pública hostil à aquisição do controle - OPA de aquisição, modalidade de sua transferência comum diante de uma estrutura dispesa do capital votante da companhia-alvo, é comum que o proponente se aproveite do déficit informacional
} 
conseqüências de se conferir tutela no momento de transferência de controle a interesses ditos 'minoritários' na companhia, tais como o de acionistas nãocontroladores e de empregados.

Preliminarmente, da tese concebida por Frank Easterbrook e Daniel Fischel pela adequabilidade do direito societário, como instrumento adequado à minimização dos custos de agência e de transação correspondentes ao exercício da sociedade anônima, é possível deduzir que, também na regulação da transferência de seu controle, deve-se, genericamente, buscar otimizar o bem-estar gerado pela sua operação, ao invés de se, ineficientemente, privilegiar determinados interesses em detrimento dos ganhos socioeconômicos potenciais decorrentes da transferência de controle. Como fundamento, observam que, mesmo se considerada legítima essa tutela específica a determinados grupos na companhia em detrimento da eficência econômico-regulamentar, o investidor não sabe ao certo se uma determinada sociedade de que seja acionista terá o seu controle como objeto de uma oferta pública de aquisição, ou se será a ofertante à aquisição do controle de outra companhia. Assim, sustentam, mesmo sob o ponto de vista dos participantes do mercado de capitais e, mais especificamente, dos acionistas da companhia como um todo, é preferível um sistema regulamentar da transferência de controle que preze pela otimização do valor econômico gerado pela sociedade anônima, identificando-o ao bem-estar social que advém da companhia.

Mesmo com relação aos investidores com um nível de aversão ao risco mais elevado, resta a possibilidade de diversificar as suas participações societárias, de modo a mitigar o risco correspondente ao valor respectivo a

entre os acionistas e decorrente da própria estrutura de capital da companhia. Por essa razão, é comum que se regule a oferta pública à aquisição em atenção a esta característica, exigindo-se, por exemplo, que a oferta pública realizada vigore por um prazo determinado, em que os acionistas-alvo poderão manifestar o seu consentimento, ou seja, aderir à oferta. A discussão dos elementos decorrentes da OPA de aquisição é realizada no item 5.2 deste trabalho. 
cada uma delas e inclusive no que tange à sua posição como participante da companhia. Nesse mesmo sentido, pela faculdade conferida aos investidores de diversificar a composição de uma carteira acionária, Frank Easterbrook e Daniel Fischel defendem que é melhor se prever um sistema eficiente à alocação do controle social a se adotar medidas que restrinjam as possibilidades de sua transferência. Assim se notou no estudo da teoria estrutural mínima da sociedade anônima proposta por Frank Easterbrook e Daniel Fischel, realizado no item 3.2 deste trabalho. Explicam os autores:

"We shall nonetheless largely ignore risk aversion with respect to public corporations. Our rationale is simple: diversification. Investors who dislike risk can get rid of it (...) A person who holds a diversified portfolio has an investment in the economy as a whole and therefore wants whatever social or private governance rules maximize the vale of all firms put together. He is not interested in maximizing one firm's value if that comes out of the hide of some other corporation. Diversification is cheap in the current economy. It costs less to buy and to hold a diversified fund than to trade a small number of stocks" ${ }^{267}$.

Diante do maior valor auferido à sociedade anônima, entende-se que, genericamente, os seus participantes são beneficiados por um sistema que facilite a transferência de controle na companhia. Essa conclusão é particularmente importante na observação das críticas que os autores que adotam a análise funcional como base teórica para o estudo das relações societárias realizam a respeito de duas dimensões elementares à transferência de controle: a atribuição regulamentar de direitos de saída análogos ao tagalong aos acionistas não-controladores da companhia e a legitimidade das estratégias de defesa à tomada de controle na sociedade anônima, objetos dos itens seguintes deste capítulo.

\footnotetext{
267“Não obstante, nós devemos praticamente ignorar a aversão ao risco relacionada à sociedade anônima registrada. A razão disso é muito simples: diversificação. Investidores que não estejam dispostos ao risco podem se livrar do mesmo (...) Um indivíduo que tenha um portfólio diversificado tem um investimento na economia como um todo e, por isso, deseja as regras de governança genéricas ou privadas que maximizem o valor que todas as companhias geram conjuntamente. Ele não está interessado em maximizar o valor de uma determinada sociedade se isso acarreta na perda de valor de outras companhias. A diversificação tem o custo reduzido na presente economia. Custa menos comprar e administrar um fundo diversificado do que transacionar um pequeno número de ações" Tradução livre. EASTERBROOK, Frank H.; FISCHEL, Daniel R.. Op. cit. p. 29.
} 
Compreendidas a transferência de controle em suas modalidades como genericamente desejáveis à luz dos pressupostos fundamentais da análise funcional do direito, seu modelo regulamentar 'ótimo' seria concebido com a finalidade de possibilitar um número elevado de transferências de controle acionário, de modo a permitir a alocação 'ótima' de sua titularidade, ou a quem lhe atribua maior valor, mediante a redução dos custos de transação referentes à operação.

Esse entendimento é justificado, sobretudo, nas hipóteses em que os interesses de administradores e acionistas sejam distintos, como, por exemplo, diante de uma oferta pública à aquisição de controle numa sociedade de capital disperso. Conforme se nota pela finalidade a que se destina a OPA de aquisição, e discutida no item 5.2 deste estudo, a probabilidade de distanciamento dos interesses de ambas as partes, acionistas e administradores, é inversamente proporcional à parcela de capital de titularidade dos administradores ${ }^{268}$. Assim, as hipóteses de serem operadas transferências de controle, diante do baixo valor auferido aos acionistas pela sua participação no capital da sociedade anônima e que decorra da gestão ineficiente da companhia, é um elemento, ao final, conjugador dos interesses de acionistas e administradores, tendo em vista que a troca de controle, habitualmente, lida ao redirecionamento dos negócios sociais e à substituição da target-board:

"Capital markets facilitate the operation of the market for corporate control (...). Managers must perform well to keep share prices high; if they do not, they can expect to be

\footnotetext{
${ }^{268}$ Frank Easterbrook e Daniel Fischel explicam o fundamento dos problemas de agência existentes entre administradores e acionistas na sociedade anônima: "When one person exercises authority that affects another's wealth, interests may diverge. The smaller the managers' share in the enterprise, the more the managers' interests diverge from the interests of those who contributed capital. This phenomenum exists in any agency relation". Ibid. p. 91. "Quando uma pessoa exerce autoridade que afeta as riquezas da outra, os interesses podem divergir. Quanto menor for a participação dos administradores no empreendimento, maior a divergência entre os interesses dos acionistas e daqueles que contribuíram com capital para a realização do empreendimento. Este fenômeno existe em qualquer relação de agência" Tradução livre.
} 
replaced. The efficient operation of the capital, labor, and takeover markets all raise the future costs of poor performance, thereby helping to assure contractual performance ${ }^{269}$.

Por partirem de pressupostos distintos, outros autores discordam desta posição. Calixto Salomão Filho defende a ilegitimidade de se, regulamentarmente, prezar pela existência de um verdadeiro 'livre mercado' do controle acionário da sociedade anônima nos termos propostos por Frank Easterbrook e Daniel Fischel por uma razão principal. Para o autor, a estabilidade na administração da sociedade anônima deve ser entendida como 'valor' a ser tutelado pelo ordenamento jurídico, pois imprescindível à gestão que entende 'ótima' da companhia, ou aquela que atenda aos tantos interesses decorrentes da atividade econômica organizada sob e pela sociedade anônima.

Somente através da imposição regulamentar de restrições à transferência de controle acionário, possibilita-se, alega Calixto Salomão Filho, que os recursos atribuíveis ao exercício da sociedade anônima sejam alocados da forma que melhor atenda aos anseios sociais correspondentes à companhia. Com a maior estabilidade conferida à administração na sociedade anônima, são estabelecidas as condições necessárias à realização de investimentos que visem a gerar resultados também no longo prazo, como, por exemplo, em pesquisa e desenvolvimento, ao invés de se induzir os administradores da sociedade anônima a buscar incessantemente o lucro social no curto prazo, unicamente por temor à perda de seus offices que decorreria da transferência do controle da companhia gerida.

Calixto Salomão Filho compreende que da expectativa permanente de realização de uma oferta pelo controle acionário, diante da percepção, pelo potencial adquirente, do subvalor atribuído pelos gestores à sociedade-alvo e

\footnotetext{
${ }^{269}$ Ibid. p. 96/97. "O mercado de capitais facilita o mercado pelo controle da sociedade anônima (...) Administradores devem exercer adequadamente as suas funções para manter o valor das ações elevado, pois se não o fizerem, podem ser substituídos. O funcionamento eficiente dos mercados de capitais, de trabalho e de tomada de controle elevam os custos futuros de mau desempenho, ajudando assim a garantir o desempenho contratado" Tradução livre.
} 
com a sua facilitação decorrente dos baixos custos de transação relacionados à operação, a sociedade anônima seria fragilizada na qualidade de instrumento concebido para o desenvolvimento da atividade econômica organizada pela companhia, tal como decairia o bem-estar social conseqüente dessa atuação ${ }^{270-}$ 271

Opõem-se as perspectivas e 'valores' em que se pode basear na regulação da transferência de controle. Resta definir se e, em que medida, a eficiência da administração da sociedade anônima decorre ou é contrária à sua estabilidade, que pode ser prescrita por meio de um sistema que, direta ou indiretamente, desencoraje a transferência do controle acionário. Discussão cujas conclusões norteiam o estudo tanto da natureza e das conseqüências dos termos de afiliação na companhia, como da legitimidade da utilização de estratégias de defesa à tomada de controle, realizado nos itens seguintes deste capítulo.

\footnotetext{
${ }^{270}$ Explica Calixto Salomão Filho: “A contínua sujeição da empresa a ataques impede a programado e utilização dos recursos para investimentos a longo prazo. E são exatamente tais investimentos os mais úteis para a economia como um todo" COMPARATO, Fábio Konder; FILHO, Calixto Salomão. Op. cit., p. 263.

${ }^{271}$ Ressalva-se que, um dos elementos considerados para se contabilizar o 'valor' da sociedade anônima é a perspectiva de sua rentabilidade, conforme enuncia o artigo 170, da Lei n ${ }^{\circ} 6.404 / 76$, em seu inciso I. Assim, da assertiva de um livre-mercado de controle acionário, tal como propõem Frank Easterbrook e Daniel Fischel, não necessariamente se infere a conclusão favorável à restrição de estímulos dos administradores na realização de investimentos no longo-prazo pelo temor de realização de uma oferta pelo controle no curto prazo e da conseqüente perda de seus offices. O raciocínio que se propõe parte das seguintes premissas: a perspectiva de rentabilidade da companhia se refere ao sucesso da estruturação dos investimentos por parte dos administradores da sociedade anônima, e não-somente à sua percepção no curto-prazo; a diversificação de investimentos é uma ferramenta disponível ao investidor para composição de sua carteira acionária, em atenção aos riscos e benefícios decorrentes tanto da estruturação das relações da sociedade anônima, como da realização de seu objeto. Logo, a participação do investidor no capital de uma determinada companhia depende do perfil que ele queira atribuir à sua participação: de maior ou menor risco e de acordo com o seu rendimento marginal sobre a rentabilidade dos investimentos realizados visando a obtenção de resultados tanto no curto, como no longo prazo Da mesma forma, o preço das ações de uma companhia dependerá da perspectiva de rentabilidade (compreendida em seu sentido amplo) que o mercado terá desta participação e que é relacionada não só a investimentos de curto-prazo. Assim, da premissa maior - livre-mercado pelo controle acionário, não necessariamente se infere a conclusão de que administradores somente realizariam investimentos de curto prazo por temor à perda de seus postos, na medida em que a perspectiva de rentabilidade da companhia também se refere aos seus investimentos de longo prazo.
} 


\subsection{O 'premium bribe' e os termos de afiliação na transferência do controle acionário}

"A requirement that no investor do worse than the prior market price is essential to ensure that corporate control transaction be value-increasing"272 (Easterbrook; Fischel, 1991).

Dentre as principais questões que surgem na transferência de controle da sociedade anônima, encontra-se a discussão sobre a natureza do valor pago em contrapartida à obtenção do controle social. A controvérsia em se, regulamentarmente, conferir ao controlador o 'prêmio' correspondente ao controle da companhia levou David Cowan Bayne a, figurativa e pejorativamente, se referir ao prêmio correspondente ao controle como 'premium bribe' atribuído ao controlador-cedente ${ }^{273}$. A discussão sobre a legitimidade para a percepção do prêmio pago em razão do controle não se confundir à titularidade de seu exercício; do apreço em se regulamentar e economicamente endereçar ao estímulo a transferência de controle acionário; e das conseqüências que de ambos esses elementos se deduz na tutela dos interesses minoritários na companhia permeia o estudo do valor do dito 'prêmio' correspondente ao controle da sociedade anônima na regulação de sua transferência.

Alfredo Lamy Filho e José Luiz Bulhões Pedreira afirmam que o valor correspondente ao controle acionário é diverso das ações que lhe correspondem, sendo-lhes distinto, em seu valor econômico "das ações que compõem o bloco de controle de per si consideradas" ${ }^{274}$. São duas as principais razões apresentadas pelos autores para que o mercado atribua ao bloco de controle acionário valor superior em comparação às demais ações

\footnotetext{
${ }^{272}$ EASTERBROOK, Frank H.; FISCHEL, Daniel R.. Op. cit., p. 200. "Exigir que nenhum investidor tenha prejuízos com relação ao preço de mercado anterior à transferência de controle realizada é essencial para se garantir que a operação seja eficiente" Tradução livre.

${ }^{273}$ BAYNE, David Cowan. Op. cit., p. 112.

${ }^{274}$ FILHO, Alfredo Lamy Filho; PEDREIRA, José Luiz Bulhões. A Lei das S.A. vol. II, $2^{\mathrm{a}}$ Ed.. Rio de Janeiro: Editora Renovar, 1996. p. 652.
} 
que compõem o capital social da companhia. Primeiro, percebe-se o bloco de controle como 'coisa coletiva', ao invés de compreendido de acordo com as ações que o integram e individualmente consideradas. E segundo, a atribuição pelo mercado desse sobrevalor justifica-se não pelas ações que ao controle correspondem, mas sim pelo: "poder de orientar os destinos da companhia e a segurança (criada por esse poder) do capital aplicado no conjunto das ações que forma o bloco de controle" ${ }^{, 75}$. Diante dessas características do prêmio correspondente ao controle na sociedade anônima, passa-se à discussão sobre as diversas teorias formuladas sobre a legitimidade subjetiva de sua atribuição.

O fundamento em que se baseiam Adolf Berle e Gardiner Means para negar a legitimidade do controlador para perceber o prêmio referente ao controle social em sua alienação relaciona-se ao fato de que, muito embora o controlador-cedente ou alienante detenha o controle da companhia, ele não é o seu real titular. A sociedade-alvo, no caso da oferta pública à aquisição de seu controle, ou a que tenha o controle cedido, em se tratando de cessão de controle acionário, é percebida pelos autores como a legítima titular para perceber o prêmio correspondente ao controle na ocasião de sua transferência. Tal como o aviamento constituído sob a sociedade anônima, o controle seria um ativo de domínio da sociedade-alvo, e não daquele que, mesmo sem ser o seu real titular, o exerça e possa decidir transferi-lo a um terceiro ${ }^{276}$.

Para se opor ao entendimento de que caberia à própria companhia receber o prêmio correspondente ao controle alienado ou adquirido por um

\footnotetext{
275 Ibid. p. 652.

276 Argumentam os autores: "The Power going with 'control' is an asset which belongs only to the corporation; and that payment for that power, if it goes anywhere, must go into the corporate treasury". BERLE, Adolf A.; MEANS, Gardiner C.. Op. cit., p. 216/217. "O poder que corresponde ao controle é um ativo que pertence somente à companhia; e o pagamento por este poder, se irá a algum lugar, deve ir aos cofres da própria companhia". Tradução livre.
} 
terceiro $^{277}$, Frank Easterbrook e Daniel Fischel baseiam-se na premissa conseqüêncialista de que também se valem para a discussão dos direitos de saída atribuíveis aos acionistas minoritários da companhia que tenha o seu controle transferido. Negar a identidade entre a titularidade do controle acionário e a legitimidade para perceber o prêmio que lhe corresponda desestimularia o controlador a ceder a sua posição jurídica ${ }^{278}$. Assim, diante da máxima extraída da discussão realizada sobre a desejabilidade econômicosocial sob uma perspectiva funcional da transferência de controle e objeto do item anterior deste estudo, qualquer regulação nesse sentido seria contrária aos interesses das partes constituintes da companhia, bem como aos potenciais ganhos socioeconômicos decorrentes da transferência de controle da sociedade anônima, pois restritivas à sua realização.

De fato, falha, por duas razões principais, a tese sustentada por Adolf Berle e Gardiner Means, favorável à legitimidade subjetiva da própria sociedade para a percepção do prêmio na transferência de seu controle e que a distingue das hipóteses assemelháveis às de alienação dos bens que integram o ativo da sociedade anônima. Primeiro, por ser concebida sem endereçar à realidade do poder de controle na sociedade anônima em sua transferência e de, assim, atribuir à pessoa diversa do titular de seu exercício o prêmio que lhe seja correspondente $^{279}$. Segundo, pelo ilogismo em se atribuir o valor pago

\footnotetext{
${ }^{277}$ Por razões metodológicas, aqui, não se tratará especificamente das distinções que a regulamentação societária atribui às situações de alienação e de aquisição do controle acionário. Neste capítulo, limitase à discussão dos principais elementos que, genericamente, se referem à transferência de controle acionário, deixando-se o estudo da regulamentação específica de cada uma de suas modalidades para o quinto e último capítulo deste trabalho.

${ }^{278}$ EASTERBROOK, Frank H.; FISCHEL, Daniel R.. Op. cit., p. 117/118.

${ }^{279}$ Os próprios autores admitem as limitações da tese em se dissociar à identidade da titularidade do controle acionário à legitimidade da percepção do prêmio que lhe corresponda: "In effect, a position of 'control' is a valuable piece of property to its holder, and so regarded; its value arises out of the ability which the holder has to dominate property which in equity belongs to others. And the Law thus far has been unable to deal with the situation". BERLE, Adolf A.; MEANS, Gardiner C.. Op. cit., p. 217. "Na verdade, a posição de 'controle' é um valioso aspecto da propriedade de seu detentor e assim é percebida pelo mercado. Seu valor corresponde à possibilidade que o seu detentor possui de dominar
} 
pelo adquirente do controle como contrapartida à sua aquisição à própria companhia-alvo ou que tenha o seu controle cedido. Ora, caso assim se impusesse por meio da regulação da sociedade anônima, o prêmio pago em razão do controle seria, ao final, atribuído justamente a quem o desembolsou para obtê-lo, diante da concretização da transferência de controle acionário em favor do adquirente e de sua integração ao quadro social da companhia ${ }^{280}$.

Diante das limitações da teoria proposta por Adolf Berle e Gardiner Means e reconhecida pelos próprios autores ${ }^{281}$, William Andrews e Richard Jennings, embora em atenção à legitimidade da companhia para a percepção do valor referente ao seu controle, propuseram uma terceira tese em que sustentam serem legítimos para compartilharem o prêmio correspondente ao controle social os próprios acionistas da companhia cujo controle seja transferido $^{282}$. Supera-se, assim, o paradoxo da formulação proposta por Adolf Berle e Gardiner Means em sua segunda dimensão criticada, ou permitir que, mesmo indiretamente, o prêmio pago em contrapartida ao controle retorne justamente a quem o desembolsou. No entanto, assim como não o faz a tese desses autores, a construção de William Andrews e Richard Jennings não resolve a primeira dimensão da criticada tese de Adolf Berle e Gardiner Means, ao não endereçar à realidade do valor do poder detido por quem o exerce na sociedade anônima, mostrando-se, assim, incompatível com a realidade do exercício da companhia ${ }^{283}$.

Propôs-se, então, uma quarta alternativa à regulamentação do prêmio da transferência de controle na companhia: atribuir-se aos acionistas da

\footnotetext{
a propriedade que pertence aos titulares do capital social da companhia. E o direito, até o momento, não foi capaz de lidar com esta situação". Tradução livre.

${ }^{280}$ COMPARATO, Fábio Konder; FILHO, Calixto Salomão. Op. cit., p. 300

${ }^{281}$ BERLE, Adolf A.; MEANS, Gardiner C.. Op. cit., p. 217.

282 ANDREWS, William. The Stockholders' Right to equal opportunity in the sale of shares. 78, Harvard Law Review, 505, 1965; JENNINGS, Richard W.. Trading in Corporate Control, 44, California Law Review, 1956. Ap. EASTERBROOK, Frank H.; FISCHEL, Daniel R.. Op. cit., p. 127.

${ }^{283}$ EASTERBROOK, Frank H.; FISCHEL, Daniel R.. Op. cit., p. 126.
} 
sociedade, cujo controle seja transferido, o valor referente ao controle, mediante a repartição de seu valor "pro rata entre todos os acionistas" 284 . Ocorre que a divisão proporcional à participação no capital social do prêmio correspondente ao controle, pelos mesmos fundamentos contrários às teses de Adolf Berle, Gardiner Means William Andrews e Richard Jennings, tampouco condiz à realidade do controle na sociedade anônima. Da exigência em se distribuir o valor pago em razão do controle em iguais condições a todos os acionistas, mesmo que em atenção às suas respectivas participações acionárias, inferem-se restrições às possibilidades de sua transferência, pelo desestímulo ao controlador de abdicar a posição que ocupa diante da impossibilidade de auferir o valor econômico correspondente ao controle. No mesmo sentido Alfredo Lamy Filho e José Luiz Bulhões Pedreira criticam as teorias que conferem igualdade de condições aos acionistas de compartilhar o valor correspondente ao prêmio por cinco razões principais. Em primeiro lugar, os autores alegam que o valor do controle não integra o patrimônio da companhia, inclusive, por surgir e desaparecer sem exercer qualquer repercussão patrimonial. Da mesma forma, muitas vezes, o controle decorre de acordos ou operações realizadas entre os acionistas, não envolvendo, portanto, a companhia de cujo controle se trate. Assim "a igualdade dos direitos conferidos às ações de mesma espécie e classe da sociedade anônima diz respeito à estrutura interna da sociedade e aos direitos de participação que integram cada ação [...] e têm por objeto os valores que existem no patrimônio da companhia, e não outras ações da mesma companhia"285 . A ação como bem de natureza móvel somente pode ser considerada pelo direito objeto de tutela, sob o ponto de vista patrimonial do acionista, e não de acordo com o correspondente direito de participação que se lhe pode atribuir razão por que a sua proteção somente se justifica inividualmente considerada, sendo a

\footnotetext{
${ }^{284}$ COMPARATO. Fábio Konder; FILHO, Calixto Salomão. Op. cit., p. 301.

${ }^{285}$ FILHO, Alfredo Lamy Filho; PEDREIRA, José Luis Bulhões. Op. cit., p. 653.
} 
chamada: 'igualdade de oportunidades' "incompatível tanto com o conceito de propriedade individual das ações, como com o direito de livremente dispor delas contido nessa propriedade".

Mais ainda, pode-se acrescentar às críticas de Alfredo Lamy Filho e José Luiz Bulhões Pedreira a constatação de Frank Easterbrook e Daniel Fischel sobre a redução do 'valor' atribuído à companhia, aos seus acionistas e genericamente percebido por toda a sociedade, em conseqüência da regulação ineficiente da transferência de controle na sociedade anônima. Elevam-se os custos de transação da transferência de controle por meio da positivação de regimes que reconhecem a igualdade de oportunidades entre acionistas como princípio, atribuindo direitos de saída comuns aos participantes do capital social votante da companhia" ${ }^{286}$ : "This unequal distribution may cut the costs to purchasers of control, increasing the number of beneficial control transfers by incentive of inefficient controllers to relinquish their positions" ${ }^{287}$.

Diante de tais fundamentos e das limitações observadas, os autores delineiam os elementos do que consideram um modelo ótimo com relação à alocação regulamentar do prêmio pago em razão do controle, pois, diferentemente dos demais propostos, ao mesmo tempo, propicia o estímulo ao seu titular em transferi-lo, (transferência essa cuja desejabilidade foi discutida no item 4.2 deste estudo), e tutela as demais partes constituintes da sociedade anônima em seus interesses:

"A legal rule that permits unequal division of gains from corporate control changes, subject to the constraint that no investor be made worse off by the transaction, maximize investor's wealth. This is really nothing more than an application of the Pareto principle of

\footnotetext{
${ }^{286}$ O histórico da regulação da alienação de controle no Brasil e da 'igualdade de oportunidade' entre os acionistas na alienação de controle é preliminarmente discutido no item 5.3 deste estudo.

${ }^{287}$ EASTERBROOK, Frank H.; FISCHEL, Daniel R.. Op. cit., p. 126. "Essa distribuição desigual [do prêmio de controle] pode acarretar na redução dos custos para o adquirente do controle, elevando o número de transferências de controle benéficas através do inventivo a controladores ineficientes abdicarem de sua posição" Tradução livre.
} 
welfare economics. Turning to the law, we show that the cases and statutes by and large mirror these economic principles" ${ }^{, 288}$.

A compreensão da transferência de controle em suas modalidades, como instrumento adequado à sua alocação eficiente, ou a quem lhe atribua maior valor, constitui o cerne da teoria dos autores. Às demais partes constituintes da sociedade anônima, sustentam, resta a proteção econômica dita 'mínima' conferida pela regulação da transferência de controle, que lhes garanta, não a participação no prêmio referente ao controle, mas o valor de seus investimentos no momento de sua operação.

A discussão sobre prover-se um sistema regulamentar que confira tratamento isonômico aos acionistas da sociedade anônima na transferência de seu controle não se limita, no entanto, à repartição do prêmio pago em razão do controle acionário. A natureza, características e, sobretudo, conseqüências dos deveres atribuíveis ao adquirente do controle social referem-se, também, à disponibilização de informações que a todos os acionistas sejam comuns com relação à transferência operada ${ }^{289}$.

Em síntese, de acordo com a fundamentação proposta ao longo do capítulo 3 anterior deste estudo, à luz da teoria estrutural mínima proposta por Frank Easterbrook e Daniel Fischel para a leitura das relações decorrentes da sociedade anônima, mesmo sob a perspectiva do acionista minoritário, melhor um sistema regulamentar que preze pela otimização do número de transferências de controle, do que restritivo à sua realização. Primeiro, pelo fato de o acionista minoritário ser capaz de auferir os melhores resultados

\footnotetext{
${ }^{288}$ EASTERBROOK, Frank H.; FISCHEL, Daniel R.. Op. cit., p. 126. "Uma norma que permita a divisão desigual dos ganhos decorrentes da transferência de controle, mas que, em contrapartida, garanta que todos os investidores não terão prejuízos com a operação, é capaz de maximizar o bemestar dos investidores. Isso nada mais é do que a aplicação do princípio de Pareto sobre o bem-estar econômico. Com relação ao direito, observa-se que casos e leis valem-se desses princípios econômicos" Tradução livre.

${ }^{289}$ No Brasil, a Comissão de Valores Mobiliários - CVM regula as informações que devem ser disponibilizadas na realização de uma oferta pública de aquisição - OPA em suas modalidades ao longo da Instrução $n^{\circ} 361$, de 5 de março de 2002.
} 
sociais advindos do maior valor atribuído como um todo ao mercado na qualidade de participantes da sociedade anônima e de investidor do produto da atividade econômica organizada. Segundo, pelo fato de a transferência de controle permitir que, ao invés de acionistas permanecerem expostos a uma administração menos eficiente em razão de restrições regulamentares impostas ao 'mercado de transferência de controle', que percebam os potenciais resultados positivos decorrentes do maior valor compreendido pelo adquirente da companhia, em comparação ao gerado pela administração presente da companhia-alvo $^{290}$.

Delineados os principais aspectos que permeiam o estudo do prêmio correspondente ao controle, bem como as relações dele decorrentes entre o adquirente, os acionistas controladores, os não-controladores e as demais partes que se relacionam com a sociedade anônima, chega-se às controvérsias sobre a natureza, os fundamentos e as consequiências econômico-sociais decorrentes da utilização de estratégias de defesa a uma oferta pública à aquisição do controle na sociedade anônima. É à luz da regulação contemporânea dos instrumentos de defesa à tomada de poder de controle na sociedade anônima que se propõe a leitura crítico-funcional de sua legitimidade.

\subsection{A análise funcional-comparativa dos instrumentos de defesa a uma oferta pública hostil de tomada de controle acionário: caracterização e fundamentos}

"The first great power of corporate manager is its capacity to determine the price for the products or the services sold by it" ${ }^{\prime 291}$ (Berle, 1969).

\footnotetext{
${ }^{290}$ EASTERBROOK, Frank H.; FISCHEL, Daniel R.. Op. cit., p. 127.

${ }^{291}$ BERLE, Adolf A.. Op. cit., p. 199. "O maior poder do administrador da companhia é a capacidade de determinar o preço dos produtos ou serviços que vende" Tradução livre.
} 
Os instrumentos de defesa a uma oferta pública hostil de tomada de controle acionário $^{292}$ podem ser entendidos como técnicas ou estratégias disponíveis à administração da companhia-alvo para tornar mais custoso ou desinteressante ao ofertante transferir o controle acionário em seu favor. Conceituam-nas Fábio Konder Comparato e Calixto Salomão Filho como as medidas de defesa de que os diretores ou controladores da sociedade-alvo podem se valer, de acordo com a alocação do direito de decidir fazê-lo, ao se oporem a uma oferta pública realizada à aquisição do controle ${ }^{293}$.

Econômica e empiricamente, Richard Posner elucida as perplexidades referentes à regulação das técnicas de defesa à tomada de controle acionário na sociedade anônima, diante de suas principais características:

"Antitakeover devices such as the poison pill are defended as promoting equality among shareholders, causing tender offerors to sweeten their offers, and correcting undervaluations by the market. These defenses are implausible, the last especially (...) Their major effect is to discourage tender offers, and some studies have shown that when tender offers are defeated the shareholders of the target corporation - all of them - suffer losses. And yet the takeover devices require the approval of the corporation's board of directors $-a$ board likely nowadays to have a majority of outsiders, Could they be acting against the corporation's interests?"294-295

\footnotetext{
${ }^{292}$ Permite-se o pleonasmo da expressão 'oferta pública hostil de tomada de controle acionário' para caracterizar o caráter conflitivo da operação. Mais técnico, no entanto, é chamá-la de 'oferta pública de aquisição do controle acionário'. Com efeito, a sua conceituação como uma oferta pública 'hostil' à aquisição do controle acionário ou aquela que objetiva a sua 'tomada' facilita a compreensão das particularidades que apresenta frente à cessão do controle acionário, pois, diferentemente dessa, a oferta pública à aquisição visa à obtenção do controle social pelo adquirente, mesmo que sem o consentimento do controlador de facto ou da administração da companhia-alvo. No presente estudo, privilegia-se tratá-la de 'oferta pública à aquisição do controle acionário', permitindo-se utilizar as demais expressões mencionadas para enfatizar a natureza da operação frente aos diversos interesses das partes que integram a companhia-alvo.

${ }^{293}$ COMPARATO, Fábio Konder; FILHO, Calixto Salomão. Op. cit., p. 247.

294 POSNER, Richard A.. Op. cit., p. 455. "Técnicas de defesa, tais como a 'poison pill', são defendidas como instrumentos disponíveis para se promover a igualdade entre acionistas, de modo a fazer com que os ofertantes do controle melhorem a sua oferta, através da correção de subavaliações realizadas pelo mercado. Esses instrumentos e, em especial, o último, são implausíveis (...) O seu principal efeito é o de desencorajar a oferta pública de aquisição do controle, e alguns estudos demonstram que quando ofertas públicas não são bem sucedidas, os acionistas da companhia-alvo em sua unanimidade - sofrem com os resultados. Em especial, as técnicas de defesa à tomada de controle demandam a aprovação da maioria dos membros da diretoria executiva da companhia - cuja composição atualmente conta, em sua maioria, com diretores independentes. Esses diretores poderiam estar agindo contra os melhores interesses da companhia?" Tradução livre. Os limites da business
} 
E ainda, questiona o autor:

"We must ask what should be the posture of the management of a takeover target. Should it advise the shareholders to accept the first offer made or should it try to delay acceptance of the offer in the hope of stimulating a competition among takeover bidders in which the stock will be sold to the highest bidder? There is some evidence that targets that do not resist tender offers yet are later acquired do better than target that do not resist; if they resist successfully, they do worse. So maybe the conflict of interest is not that serious after all ${ }^{296}$.

O estudo funcional das técnicas de defesa à tomada de controle baseiase nos conflitos de agência decorrentes de sua utilização como instrumento restritivo à transferência do controle acionário. A análise dos potenciais conflitos de interesse entre os participantes da sociedade anônima sobre os termos que regem a oferta pública aos acionistas da companhia-alvo, tais como a legitimidade subjetiva para a tomada de decisão favorável à utilização de estratégias de defesa diante de uma oferta indesejada, norteia o estudo da classificação em espécie das técnicas de defesa realizado em seguida nesta seção.

Segundo sua leitura funcional, os problemas decorrentes da possibilidade de se buscar obstar uma oferta pública hostil à aquisição do controle, não mediante a negativa de parcela do capital social votante da

judgment rule na interpretação dos negócios sociais e, aqui especificamente, na verificação da juridicidade da utilização da poison pill, são discutidos ao final deste item e apresentados, em seus fundamentos, no capítulo 1 deste trabalho.

${ }^{295}$ O próprio Richard Posner evidencia a importância da análise dos instrumentos de defesa à tomada de controle acionário à luz da tutela aos acionistas da sociedade anônima: "If the studies that find that antitakeover devices hurt the shareholders are right, this suggests both that the market for corporate control is not working well and that its failure is a serious one". Ibid. p. 456. "Se os estudos que compreendem a utilização de técnicas de defesa como hostil aos interesses dos acionistas da companhia estão corretos, isso sugere que o presente mercado de transferência de controle da companhia é ineficiente e que essa falha é de extrema importância" Tradução livre.

${ }^{296}$ Ibid. p. 456. "Devemos indagar quanto à postura que os administradores da companhia-alvo devem adotar. Deveriam recomendar aos acionistas aceitar a primeira oferta realizada, ou tentar postergar a sua aceitação na esperança de estimular a competição entre possíveis adquirentes, numa situação em que o controle seria transferido para o melhor ofertante? Observam-se evidências de que companhiasalvo que resistem à oferta pela aquisição são posteriormente adquiridas em melhores condições que aquelas que não resistem; se resistem com sucesso, acabam sendo prejudicadas. Assim, talvez o conflito de interesses [entre administradores e acionistas] não é tão relevante como aparenta" Tradução livre. 
companhia-alvo, mas por meio da adoção de técnicas especificamente concebidas para este fim, reside nos problemas de agência correspondentes à alocação do poder decisório em adotá-las ou não. Explica Richard Posner:

"They have [corporate officers and managers], after all, a conflict of interest, since if the corporation is taken over they are quite likely to lose their positions on the board, which pay handsome fees. (...) More puzzling is why shareholders endorse antitakeover devices -for such devices often require, and often receive, the endorsement of a majority of the shareholders as well as of a majority of the board of directors"

Ao final, independentemente da regulação da transferência de controle acionário em seus demais elementos, a prescrição de um sistema regulamentar mais ou menos permissivo à adoção de técnicas de defesa à tomada de poder de controle, diante de sua relevância, implica na prescrição de um modelo mais ou menos adequado à estabilidade vis à vis eficiência da gestão da sociedade anônima, de acordo com os pressupostos em que o estudioso pode se basear e conforme discutido no item 4.3 deste capítulo ${ }^{298}$.

Tendo em vista a regra de alocação do direito de decidir sobre a aceitação ou não da oferta pelo controle nos termos dispostos pelo proponente

\footnotetext{
${ }^{297}$ Ibid. p. 456. "Eles [os administradores da companhia-alvo] possuem um conflito de interesses frente à companhia, tendo em vista que, caso a companhia tenha o seu controle adquirido, é bastante provável que os administradores percam a posição que ocupam na gestão da companhia e, conseqüentemente, a remuneração correspondente à sua função. Mais problemático é entender o porquê dos acionistas da companhia-alvo concordarem com a adoção de técnicas de defesa à tomada do controle - instrumentos que comumente demandam, tanto a concordância de maior parcela do capital social, como dos diretores da sociedade anônima" Tradução livre. A razão para essa possível alocação do poder decisório na adoção de estratégias de defesa à tomada de controle não endereça adequadamente aos problemas de agência decorrentes da operação e que foram apresentados no item 3.4 deste trabalho, posto que, conforme nota Richard Posner, comumente, a decisão por se adotar uma dada estratégia de defesa é deliberada, tanto na esfera da assembléia geral, como por seus administradores. O assunto é tratado adiante e concluído no item 5.2 deste ensaio.

${ }^{298}$ Conforme discutido no item 4.3 anterior deste estudo, enquanto Frank Eastebrook e Daniel Fischel defendem a importância instrumental de se prezar por um 'livre mercado de controle da sociedade anônima', como técnica de eficiência à gestão da companhia, Calixto Salomão Filho entende a estabilidade na administração dos negócios sociais como 'valor' a ser tutelado pelo ordenamento jurídico, a fim de que se prescrevam as condições necessárias à gestão que melhor atenda aos anseios sociais da atividade desenvolvida pela sociedade anônima. Tal como no estudo das demais dimensões que se referem aos termos de transferência de controle social, o debate sobre a legitimidade das técnicas de defesa à tomada de controle acionário remete, também, à discussão sobre a desejabilidade ou não da transferência de controle da sociedade anônima sob um prisma econômico-funcional, conforme analisado ao longo dos três primeiros itens deste capítulo.
} 
ou, em outras palavras, de se facultar à administração ou à assembléia geral da companhia-alvo, ou, conjuntamente a ambas, adotar instrumentos de defesa à oferta realizada, pode-se, genericamente, classificar os sistemas regulatórios das técnicas de defesa à oferta pelo controle acionário em dois grandes grupos. O primeiro, integrado pelo modelo regulamentar da transferência de controle adotado nos Estados Unidos e composto pelos sistemas regulatórios que facultam aos administradores da companhia-alvo (agentes) decidir pela conveniência ou não de se adotar estratégias de defesa à oferta proposta pelas ações da companhia-alvo a seus titulares (principais). E o segundo, integrado pelos sistemas que impõem aos administradores da companhia-alvo a regra de passividade frente à oferta realizada, de modo que cabe unicamente aos acionistas da target decidir por sua aceitação ou não, assim como o modelo britânico adotado na 'City' 299 .

Diante da leitura das relações da sociedade anônima realizada à luz dos problemas de agência entre os seus participantes, compreende-se que os sistemas que adotam o segundo modelo ou prescrevem a regra de passividade dos administradores no curso da oferta de aquisição, o fazem em atenção aos conflitos de agência decorrentes da dissociação entre a propriedade e a gestão da companhia e discutidos, em especial, no item 3.4. deste ensaio. Aqui, pela relevância da transferência de controle ao exercício da sociedade anônima e aos interesses de seus participantes, aloca-se, no próprio acionista, o poder decisório sobre a aceitação ou não da oferta realizada. Atam-se as mãos dos administradores, agentes da companhia-alvo, e se faculta, aos próprios acionistas, como seus principais, atenderem da forma que melhor lhes

\footnotetext{
${ }^{299}$ A classificação dos sistemas regulatórios pelo critério da regra de passividade dos administradores da companhia-alvo ou nos termos de sua conduta na condução da oferta adotada neste estudo é proposta por Paul Davies e Klaus Hopt e remete aos problemas de agência na sociedade anônima discutidos ao longo do item 3.4. DAVIES, Paul; HOPT, Klaus. Op. cit., p. 178 e ss.
} 
convenha aos seus próprios interesses, ao decidir pelo sucesso ou não da oferta que lhes é realizada $^{300}$.

Tal como a classificação das estratégias que integram o direito societário em regulatórias e de governança proposta por Henry Hassmann e Reinier Kraakman e delineada no item 3.4 deste estudo, os instrumentos de defesa à tomada de controle acionário podem ser classificados em duas categorias principais quanto ao momento de previsão pela sua adoção, ou exante e ex-post à oferta pública para a aquisição do controle social. Ilustrativamente, enquanto a possibilidade de adoção de uma 'poison pill' tem a previsão e condições de utilização prescritas estatutariamente ou ex-ante à oferta pelo controle, a denominada 'busca por um white knight', que visa a evitar que o controle seja transferido a um adquirente indesejado mediante a procura por um proponente alternativo ao primeiro, ocorre posteriormente ou ex-post à oferta pública de aquisição de controle.

De forma análoga são classificadas por Calixto Salomão Filho. O autor propõe a divisão das técnicas de defesa em estruturais, passíveis de serem adotadas pelos administradores da sociedade anônima ou pela assembléia geral em decorrência da regulação societária, e as que trata como estatutárias, pois disponíveis aos administradores da companhia-alvo mediante a introdução de cláusulas específicas em seu estatuto social e a que se refere genericamente sob a rubrica de 'poison pills ${ }^{, 301}$. Dentre as principais técnicas de defesa ditas estruturais ou adotáveis ex-post à oferta pública de aquisição de controle, destacamos seis: crown jewl, greenmail, a 'busca por um white

\footnotetext{
300 Como se observa no estudo das espécies de técnicas de defesa, 'atar-se as mãos' dos administradores da companhia-alvo não implica na sua integral passividade frente à oferta pública pela tomada do controle social. Aqui, se vale da expressão, a fim de ilustrar a distinção entre as duas categorias de sistemas regulatórios da transferência de controle da sociedade anônima classificadas de acordo com a regra de passividade imposta aos administradores da companhia-alvo e apresentadas em seguida. Ibid. p. 178.

${ }^{301}$ COMPARATO, Fábio Konder; FILHO, Calixto Salomão. Op. cit., p. 248.
} 
knight', pac man em duas de suas modalidades e, finalmente, o recurso à autoridade pública, a fim de se obstar a operação por sua ilegalidade. Conforme explica Kenneth Clarkson, a utilização do 'crown jewel' refere-se à seguinte hipótese:

"When threatened with a takeover, management makes the company less attractive to the raider by selling to a third party the company's most valuable asset (the "crown jewel")" 302 .

Conforme atenta Calixto Salomão Filho, a estratégia de se alienar parcela do ativo da companhia-alvo, a fim de tornar a aquisição de seu controle menos atrativa da perspectiva do adquirente, diante da redução do valor que se lhe atribui, pode vir a atentar, justamente, contra a empresa: fundamento e objeto da sociedade anônima. Por afetar a perspectiva de lucro do adquirente com relação ao exercício do controle que ofertou a aquisição, a juridicidade de adoção da estratégia 'crown jewel' reside na possibilidade conferida à administração ou à assembléia geral de alienar determinados ativos da companhia-alvo que não os que integrem a azienda, mas que, por razões estratégicas ao adquirente, compreende-se que, sem os quais, o ofertante perderá ou reduzirá o seu interesse na obtenção do controle social ${ }^{303-}$ 304-305

O segundo instrumento que compõe o grupo de estratégias ex-ante de defesa à tomada de controle, ou, genericamente, como espécie potencial da

\footnotetext{
${ }^{302}$ CLARKSON, Kenneth W. et. al. Op. cit., p. 814. "Ameaçada por uma oferta de tomada do controle, a administração torna a companhia menos atrativa ao adquirente através da alienação do seu ativo mais valioso" Tradução livre.

${ }^{303}$ COMPARATO, Fábio Konder; FILHO, Calixto Salomão. Op. cit., p. 248.

${ }^{304}$ DAVIES, Paul; HOPT, Klaus. Op. cit., p. 158.

${ }^{305}$ Ressalva-se que, segundo a Lei das Sociedades por Ações, a alienação dos bens que integram o ativo fixo da companhia compete ao conselho de administração. Dispõe seu artigo 142, VIII: compete ao conselho de administração: autorizar, se o estatuto não dispuser em contrário, a alienação de bens do ativo permanente, a constituição de ônus reais e a prestação de garantias a obrigações de terceiros". Assim, a juridicidade de adoção da crown jewel reside na busca pelo melhor interesse da companhia realizada pelos administradores, de acordo com os deveres prescritos por lei e, conforme discutiu-se no item 3.3 deste trabalho, com fundamento comum no dever de fidúcia dos administradores.
} 
categoria de técnicas estruturais na classificação proposta por Calixto Salomão Filho, é denominado de 'greenmail' ou 'blackmail'. Assim a contextualiza Kenneth Clarkson:

"To regain control, a target company may pay a higher-than market price to repurchase the stock bought by the acquiring corporation. When a takeover is attempted through a gradual accumulation of target stock rather than a tender offer, the intent may be to get the target company to buy back the shares at a premium price - a concept similar to blackmail $^{306}$.

Diante da natureza e da finalidade a que se destina o 'greenmail', Calixto Salomão Filho a entende como nociva a ambos, acionistas e companhia-alvo. Tamanha a prejudicialidade da estratégia de se permitir à sociedade comprar as ações de sua própria emissão por um preço elevado, a ponto de induzir o pretendente a renunciar à oferta realizada, que os autores destacam a sua vedação no sistema regulamentar norte-americano ${ }^{307}$. No Brasil, a ilegalidade em se adotar a estratégia refere-se, em especial, a dois fundamentos. Genericamente, o artigo 30, da Lei $n^{\circ}$ 6.404/76, impõe limitações à companhia-alvo na aquisição das ações de sua própria emissão e, temporalmente, o artigo $2^{\circ}$, 'e', da Instrução CVM n ${ }^{\circ} 10$, de 14 de fevereiro de 1980, restringe a aquisição pela companhia-alvo de qualquer parcela de seu capital no curso de uma oferta pública à aquisição de suas ações ${ }^{308-309}$.

\footnotetext{
${ }^{306}$ CLARKSON, Kenneth W. et. al. Op. cit., p. 814. "A fim de, novamente, adquirir o controle, a companhia-alvo pode pagar um valor mais elevado que o de mercado para re-adquirir o bloco de ações obtido pela companhia adquirente. Quando se tenta tomar o controle acionário da companhia-alvo através da acumulação graduação de ações que integram o seu capital votante, ao invés de mediante uma oferta pública à sua aquisição, a intenção do adquirente pode, na verdade, ser a de fazer com que a companhia-alvo compre as suas próprias ações mediante o pagamento de um prêmio - conceito similar ao de 'blackmail"' Tradução livre.

${ }^{307}$ COMPARATO, Fábio Konder; FILHO, Calixto Salomão. Op. cit., p. 248.

308 A leitura do art. 2º alínea 'e', da Instrução CVM n' 1014 de fevereiro de 1980 fundamenta a posição dos autores "A aquisição, de modo direto ou indireto, de ações de emissão da companhia, para permanência em tesouraria ou cancelamento, é vedada quando: 'e' - estiver em curso oferta pública de aquisição de suas ações”. Ibid. p. 248.

${ }^{309}$ No presente ensaio, se propõe realizar o estudo genérico da natureza e espécies das técnicas de defesa à tomada de controle acionário, e não-somente das passíveis de adoção num determinado ordenamento jurídico. Assim, por razões metodológicas e de acordo com a classificação proposta por Calixto Salomão Filho, são discutidas, na análise em espécie das estratégias de defesa à oferta pública
} 
A terceira técnica estrutural de defesa à tomada de controle acionário é a 'busca por um white knight' realizada pelos participantes da companhia-alvo, a fim de que se possibilite a disputa entre ele e o ofertante indesejado, para a aquisição do controle social. Propondo uma acepção estrita de estratégia de defesa à tomada de controle, explica Kenneth Clarkson:

"The target corporation solicits a merger with a third party, which then makes a better (often simply a higher) tender offer to the target's shareholders. The third party that "rescues" the target is the "white knight",

A característica que diferencia 'a busca por um 'white knight' de outras técnicas ex-post de defesa à tomada de controle social é a possibilidade de ser adotada pela administração da companhia-alvo, em qualquer modelo regulamentar que se prescreva ao comportamento de seus administradores no curso da oferta, ou se impositivo ou não à regra de passividade frente à oferta realizada. Independentemente da possibilidade regulamentar de os administradores (agentes) adotarem estratégias de defesa à tomada do controle, mesmo que sem o consentimento dos acionistas da companhia-alvo (principais) e tal como a estratégia de se apelar à autoridade regulamentar para obstar a oferta, estratégia esta cuja natureza se discute a seguir, é possível buscar-se um 'white knight' em qualquer modelo regulatório. Dessa forma, mesmo em sistemas, tais como o britânico da City, nos quais se impõem a regra de passividade aos administradores da companhia-alvo no curso da condução da oferta pública de aquisição do controle, esta limitação não alcança a adoção específica destas estratégias estruturais, pois a target-board

pelo controle acionário, aquelas que, sob o ordenamento jurídico brasileiro, são estruturais, pois de adoção possível à luz da regulação da sociedade anônima vigente no Brasil e, incidentalmente, em outros sistemas. Genericamente, correspondemos as técnicas que podem ou não ser adotadas no ordenamento jurídico à categoria ex-post de técnicas de defesa disponíveis à target-board, pois relacionadas ao momento da decisão por sua adoção com relação à oferta realizada, independentemente de sua juridicidade em um dado ordenamento jurídico. COMPARATO, Fábio Konder; FILHO, Calixto Salomão. Op. cit., p. 248.

${ }^{310}$ CLARKSON. Kenneth W., et. al. Op. cit., p. 814. “A companhia-alvo solicita sua incorporação com uma outra, que realiza uma oferta com melhores condições (comumente, somente mais elevada) aos acionistas da companhia-alvo. Este terceiro é o "white knight" Tradução livre. 
permanece livre para adotar, ao menos, três condutas. A primeira, pleitear o apoio dos acionistas contra a oferta. A segunda, questionar, frente às autoridades competentes, a regularidade de sua realização, conforme discutido adiante, e a terceira, buscar um "white knight" que evite a transferência do controle em favor do ofertante indesejado ${ }^{311}$.

Conforme alertam Paul Davies e Klaus Hopt, o aparente efeito positivo que facultar à administração da companhia a possibilidade de se buscar outros ofertantes pelo controle pode exercer sobre o bem-estar dos acionistas, pois, inicialmente, favorável à existência de ofertas competidoras, pode, na verdade, mostrar-se contrário aos seus melhores interesses. Diante da faculdade conferida aos administradores de se buscar um 'white knight', é racional a potenciais ofertantes não realizar a primeira oferta pelo controle da companhiaalvo, mas, ao revés, aguardar para competir com ofertas que já estejam em curso. Assim, ao invés de benéfica aos acionistas, possibilitar regulamentarmente a existência de ofertas competidoras pode restringir a realização de ofertas endereçadas pelo controle da sociedade anônima e, ao assim fazê-lo, reduzir o número de transferências operadas. Logo, ao menos economicamente, um modelo regulamentar mais eficiente sob a ponto de vista funcional imporia a regra passividade estrita à administração da companhia ${ }^{312-}$ 313

\footnotetext{
${ }^{311}$ DAVIES, Paul; HOPT, Klaus. Op. cit., p. 165.

312 Esta é a posição de Paul Davies e Klaus Hopt: "Although such action would seem to expand rather than restrict shareholder choice, it can be argued that the risk of a competitor means that some first bids will not be made at all and thus the overall number of bids is reduced. By contrast, a passivity rule would increase the number of bids and thus overall shareholders wealth". Ibid. p. 166. "Embora essa possibilidade [de se buscar um competidor pelo controle da sociedade anônima] possa parecer expansiva, sob o ponto de vista das opções dos acionistas, pode-se argumentar que o risco de um eventual competidor significa que algumas primeiras ofertas jamais serão realizadas e, por isso, o número total de ofertas será reduzido. Por sua vez, a regra de passividade [imposta aos administradores da companhia-alvo] elevaria o número de ofertas e, conseqüentemente, do bem-estar dos acionistas" Tradução livre.

313 Observa-se que os fundamentos em que se baseiam os autores para negar a legitimidade econômico-social da 'busca por um white knight', como técnica de defesa estrutural, são
} 
Kenneth Clarkson, metaforicamente, denomina 'pac man' a quarta técnica de defesa ex-post ou estrutural à tomada de controle social, em remissão ao famoso jogo eletrônico lançado em 1980, e que ocorre quando "the target corporation attempts its own takeover of the acquiring corporation" ${ }^{314}$. Da denominação amplamente atribuída pelo autor a somente uma estratégia, pode-se lhe relacionar uma quinta modalidade de estratégia $e x$ post de defesa à tomada de controle acionário, em que são os próprios administradores da companhia-alvo que buscam adquirir o controle acionário mediante a realização de uma contra-oferta aos acionistas da companhia cuja gestão lhes caiba ${ }^{315}$.

A sexta e última modalidade de estratégia de defesa ex-post à oferta de tomada de controle estudada refere-se à técnica passível de ser utilizada pelos administradores de uma companhia-alvo, independentemente ao modelo regulamentar adotado no que tange à regra de passividade de seu comportamento. Tal como se discutiu sobre a estratégia de buscar um "white knight" para evitar que a companhia-alvo tenha o seu controle transferido em favor de um adquirente indesejado, o recurso às autoridades competentes, sob a alegação de violação ao direito concorrencial ou por outro fundamento imputável ao proponente, pode ter lugar em qualquer modelo regulamentar. Para suceder e obstar a transferência de controle pretendida pelo ofertante, a

genericamente aplicáveis, pelas razões apresentadas, a quaisquer sistemas que permitam a existência de ofertas competidoras pelo controle acionário, pois nestes persiste a possibilidade de serem realizadas outras ofertas aos acionistas da companhia-alvo, independentemente de se permitir sua busca pela target-board.

${ }^{314}$ CLARKSON, Kenneth W., et. al. Op. cit., p. 814. "[a estratégia pac man ocorre quando] a companhia-alvo tenta adquirir o controle da companhia adquirente" Tradução livre.

${ }^{315}$ Com relação à modalidade em que são os próprios administradores que ofertam a aquisição do controle social, ressalva Calixto Salomão Filho: "No direito positivo brasileiro, não parece haver qualquer óbice per se a uma tal atuação dos administradores, desde que evidentemente não constitua aproveitamento de informações privilegiadas obtidas em razão do cargo (art. 155, I, da Lei nº. 6.404/76)". COMPARATO, Fábio Konder; FILHO, Calixto Salomão. Op. cit., p. 248. Pode-se estender a restrição apontada pelo autor a todas as demais estratégias enunciadas, como vedação genericamente imposta aos administradores na condução dos negócios sociais. 
estratégia em questão deve se fundar em dois aspectos principais. Primeiro, na ilegalidade da operação, como, por exemplo, pela tentativa irregular de concentração de mercado por parte do ofertante; segundo, pela competência da entidade recorrida em obstar ou desconstituir a operação.

Com efeito, conforme destaca Kenneth Clarkson, a tutela conferida pelo direito concorrencial, como instrumento de defesa à tomada do controle acionário, é somente incidental, pois o seu objeto final é a proteção do mercado compreendido como um todo, e não de agentes econômicos individualmente considerados e, muito menos, de eventuais administradores da companhia-alvo que temem perder os seus respectivos offices:

"Antitrust laws are designed to protect competition rather than competitors, incumbent managers who are able to avoid a takeover by resorting to the use of private antitrust actions are unintended beneficiaries of the laws" ${ }^{316}$.

Apresentadas as principais espécies que compõem a categoria de estratégias ex-post ou estruturais de defesa à tomada de controle, passa-se à análise de duas técnicas estatutárias ou previstas ex-ante à realização da oferta pelo controle por parte do adquirente.

A primeira técnica que compõe o par de estratégias estatutárias ou exante de defesa à tomada de controle aproxima-se, por razões pertinentes aos conflitos de agência entre administradores vis-à-vis acionistas da companhiaalvo, às demais modalidades que integram a categoria. A estratégia ex-post estatutária denominada 'golden parachutes' ou 'golden umbrella' pode, em síntese, ser compreendida como: "contracts guaranteeing extravagant

\footnotetext{
316 CLARKSON, Kenneth W. et. al. Op. cit., p. 813. "O direito concorrencial é concebido para proteger a competição, e não competidores, administradores que são capazes de evitar a tomada de controle acionário por meio de ações em que aleguem violações ao direito concorrencial são beneficiários não-intencionais das leis que o integram" Tradução livre.
} 
severance pay to managers let go as a result of a takeover"317. Kenneth

Clarkson contextualiza a adoção da técnica:

"When a takeover is successful, top management is usually changed. With this in mind, a company may establish special termination or retirement benefits that must be paid to top managers if they are "retired". In other words, a departing high-level manager's parachute will be "golden" when he or she is forced to "ball out" of the company"

À luz da classificação proposta por Henry Hassmann e Reinier Kraakman, estudada no item 3.4 deste ensaio, a finalidade de se utilizar a técnica 'golden parachutes' na sociedade anônima consiste em se buscar o alinhamento entre os interesses de acionistas e administradores. Trata-se da utilização estatutária do par de estratégias de governança de 'incentivos aos agentes' indicados ou, mais especificamente, de recompensá-los por avançar os interesses dos principais da companhia, seus acionistas. A principal finalidade de se utilizar instrumentos tais como o 'golden parachutes' é reduzir os custos de agência correspondentes aos distintos interesses internos à companhia-alvo no que tange à aceitação da transferência de controle, no caso, de administradores buscarem manter a qualquer custo seus offices e acionistas extraírem o maior valor por suas posições.

Com efeito, Paul Davies e Klaus Hopt entendem que a utilização de técnicas da natureza do 'golden parachutes' é um legítimo instrumento de redução dos custos de agência tão-somente nos sistemas que integram o primeiro modelo regulamentar sobre o comportamento dos administradores da companhia-alvo na condução de uma oferta pública pela aquisição de seu

\footnotetext{
${ }^{317}$ POSNER, Richard A.. Op. cit., p. 455. "[A estratégia 'golden parachutes' ou 'golden umbrella' pode ser compreendida] como um contrato que garante o pagamento de um valor extravagante aos administradores em razão de sua saída da companhia-alvo fundada na tomada de controle social" Tradução livre.

${ }^{318}$ CLARKSON, Kenneth W. et. al. Op. cit., p. 814. Quando uma aquisição de controle é bem sucedida, geralmente, a composição da administração da sociedade anônima é alterada. Diante disso, uma companhia pode prever planos de saída ou benefícios de aposentadoria que devem ser pagos aos administradores se eles "se aposentarem". Em outras palavras, o 'parachutes' do administrador retirante de alto nível será de "ouro" quando ele é forçado a se retirar da companhia" Tradução livre.
} 
controle, ou que lhes permita utilizar estratégias de defesa frente a uma oferta indesejada pelo controle social, assim como o modelo norte-americano. Tal como no regime britânico de regulação de takeovers, a prática em se recompensar os administradores, por avançarem os interesses dos acionistas aceitantes quando nada poderiam fazer diretamente para obstar a operação, é vista com desconfiança pelos participantes do mercado, já que, de todo modo, é imposta à target-board a regra de passividade frente à oferta realizada ${ }^{319}$.

Richard Posner destaca a natureza paradoxal que a estratégia 'golden parachutes' possui. Atribuir aos administradores um 'direito de saída' através de sua recompensa pelo sucesso de uma transferência de controle operada é uma estratégia que, embora eleve os custos de transação correspondentes à tomada de controle, é capaz de mitigar os conflitos de agência entre os melhores interesses pelo sucesso da oferta dos acionistas da companhia-alvo, principais, e de seus agentes, os administradores da sociedade anônima. Endereça-se, assim, às hipóteses de 'management entrenchment', decorrentes do distanciamento entre o interesse social, daquele dos administradores da sociedade anônima, e justamente relacionadas ao conceito de custos de agência. Questionamento que remete à discussão sobre a segunda e mais polêmica técnica ex-ante ou estatutária de defesa à tomada de controle acionário: a 'poison pill'. Opina o autor:

"The golden parachute is less objectionable than the poison pill. A guarantee of high severance pay triggered by a takeover makes takeovers more costly, but also reduces the incentive of managers to resist takeovers; the effects may be offsetting", ${ }^{, 20}$.

\footnotetext{
319 Como exemplos, os autores citam dois modelos: o adotado na City britânica, em que tais pagamentos aos administradores em razão da perda dos 'offices' ocupados somente podem ser feitos com a autorização dos acionistas ( $\S 314-316$, Company Act, UK), e a regulação germânica, em que a adoção da estratégia golden parachutes de se compensar os administradores por ocasião da transferência de controle é expressamente vedada (\$33 (3) Übernahmegesetz). DAVIES, Paul; HOPT, Klaus. Op. cit., p. 168.

${ }^{320}$ POSNER, Richard A.. Op. cit., p. 455. “A técnica 'golden-parachutes' é menos questionável que a 'poison pill'. Garantir o pagamento de prêmios aos administradores da companhia-alvo na ocorrência da tomada de seu controle acionário faz com que a transferência de controle seja mais custosa, mas, em
} 


\section{A definição da 'poison pill' proposta por Kenneth Clarkson ilustra a} finalidade principal a que essa técnica ex-ante ou estatutária de defesa à tomada de controle acionário se destina:

"The target corporation issues to its stockholders rights to purchase additional shares at low prices when there is a takeover attempt. This makes the takeover undesirably or even prohibitively expensive for the acquiring corporation",321-322.

\section{Explica Julian Velasco:}

"The poison pill operates in a fairly simple manner. A company's board of directors adopts a "Shareholder Rights Plan" pursuant to which a dividend of one "Right" is declared on each share of common stock. Each Right is attached to, and not tradable separately from, its corresponding share. Initially, the Rights are essentially meaningless. However, if certain specified events occur, such as the acquisition by a hostile bidder of more than a specified percentage of the company's shares, the poison pill is triggered. Once triggered, the Rights would detach from the shares and entitle all of the target company's shareholders, other than the hostile bidder, to acquire securities at a discount. The type of securities that may be acquired depends upon the type of Rights. "Flip-over" Rights allow the holders to purchase shares in the acquiring company under certain circumstances, "flipin" Rights allow the holders to purchase shares of the target company, and "back-end" Rights entitle the holders to acquire debt securities or other assets" ${ }^{, 323}$.

Em qualquer de suas modalidades, a finalidade da 'poison pill' é elevar o valor de aquisição do controle da companhia, a ponto de torná-la desinteressante ao adquirente ${ }^{324}$. Julian Velasco apresenta três alternativas ao

contrapartida, mitiga o incentivo de administradores a resistir à tomada de controle. Os efeitos podem se compensar" Tradução livre.

${ }^{321}$ CLARKSON, Kenneth W. et. al. Op. cit., p. 814. "A companhia-alvo emite em favor de seus acionistas opções de compra de ações por preços baixos diante da tentativa de tomada de controle. Isso faz com que a operação se torne indesejavelmente ou, até mesmo, absurdamente custosa para a companhia adquirente" Tradução livre.

${ }^{322}$ Assim como o conceito elaborado por Kenneth Clarkson, a definição de 'poison pill' proposta por Paul Davies e Klaus Hopt destaca a finalidade da técnica de tornar a operação suficientemente custosa para o ofertante, de modo a desencorajá-lo de adquirir o controle acionário da companhia-alvo: "The essence of the poison pill is that the Crossing by an acquirer of a relatively low threshold of ownership triggers rights for target shareholders in relation to the shares of either the target or the acquirer, (...) and which render the acquisition of further shares in the target fruitless or impossibly expensive". Davies, Paul; HOPT, Klaus. Op. cit., p. 169. "A essência da 'poison pill' ' reside na aquisição por parte do adquirente de uma parcela relativamente pequena do capital da companhia e que enseja o direito dos acionistas da companhia-alvo com relação às ações, seja da companhia-alvo ou do adquirente (...) e que o obriga à aquisição de outras ações por um valor extremamente elevado" Tradução livre.

${ }^{323}$ VELASCO. Julian, Op. cit., p. 383.

${ }^{324}$ Conforme destaca Julain Velasco: "The poison pill derives its effectiveness from this deterrence value the incumbent management can remain in power because the hostile bidder cannot afford to trigger the poison pill". VELASCO, Julian, Op. Cit., p. 383. "A efetividade da'poison pill'deriva de 
adquirente para, diante da iminência ou da efetiva utilização da poison pill pela companhia-alvo, suceder na tentativa de adquirir o controle acionário ${ }^{325}$. A primeira é buscar a obtenção do controle através de sua aquisição amigável. No entanto, conforme o próprio autor ressalva, a hipótese é paradoxal em seus próprios termos, pois: "This is little more than a phantom option; if a friendly transaction were feasible, a hostile bid would not have been necessary"326.

Uma segunda alternativa disponível ao adquirente frente à adoção da 'poison pill' pela administração da companhia-alvo é recorrer à autoridade judicante competente, para que seja reconhecida a ilicitude da técnica de defesa utilizada. Por exemplo, pela quebra dos deveres fiduciários dos administradores da companhia frente aos acionistas, seus principais, e cujos interesses, consubstanciados no melhor interesse da companhia, lhes compete atender. Através da remoção da poison pill, permite-se que a oferta prossiga nos termos propostos ao mercado. Essa possibilidade conferida ao adquirente é análoga à técnica estrutural ou ex-post disponível aos administradores da sociedade anônima de recorrer à autoridade administrativa competente sobre a eventual irregularidade da aquisição do controle objetivada pelo ofertante. Observam-se as mesmas limitações em tal estratégia e na remoção da poison pill. À luz do entendimento jurisprudencial da Suprema Corte do Estado de Delaware e da realidade do mercado de capitais norte-americano, ressalva Julian Velasco:

"Courts are not easily persuaded. The target company can often develop a plausible rationale for resisting the hostile takeover in the interests of its shareholders. Despite the obvious benefits to shareholders, who would prefer to sell their shares at an often substantial premium to market price, courts are hesitant to second-guess the business

seu valor proibitivo através do qual a administração da companhia-alvo consegue se manter na sociedade anônima, porque o adquirente do controle não consegue pagar o valor suficiente para superar a poison pill" Tradução livre.

${ }^{325}$ Ibid. p. 383.

${ }^{326}$ Ibid. p. 383. 
judgment of directors. Thus, the courts tend to permit the target company's directors to resist hostile takeovers, by means of the poison pill or otherwise, 327.

Como terceira alternativa à utilização da poison pill pela target-board, o adquirente pode tentar remover os administradores da companhia-alvo e eleger os seus próprios, com o fim de alterar a receptividade dos agentes, responsáveis pela adoção da técnica de defesa, à oferta pública hostil de aquisição do controle acionário: "The third way around the poison pill is to launch a proxy contest to remove the target company's board of directors and replace them with a more sympathetic group ${ }^{, 328}$.

A juridicidade da poison pill no ordenamento jurídico brasileiro é questionada por Fábio Konder Comparato e Calixto Salomão Filho. Os autores destacam o caráter 'potestativo' da cláusula que prevê a possibilidade de se adotar a poison pill diante de uma oferta pelo controle acionário. Dentre as modalidades de poison pill existentes, os autores enunciam a possibilidade de a companhia-alvo emitir títulos de vencimento condicionado a uma alienação de controle ou à aquisição, pelo potencial adquirente, de um percentual do capital social votante:

"Fala-se tanto na emissão de debêntures como de bônus de subscrição respectivamente resgatáveis e exercitáveis em caso de alienação de controle em condições muito favoráveis para o titular, de modo a impedir ou tornar desinteressante a aquisição para o potencial adquirente de controle" ${ }^{, 329}$.

Sobre a possibilidade jurídica de se prescrever estatutariamente a poison pill, questionam os autores:

\footnotetext{
${ }^{327}$ Ibid. p. 383. "Tribunais não são facilmente persuadidos. A companhia-alvo pode, muitas vezes, oferecer uma argumentação plausível para resistir à aquisição hostil, em atenção aos interesses de seus acionistas. Apesar das evidentes vantagens para os acionistas, que prefeririam vender as suas ações a um prêmio muitas vezes substancial com relação ao valor de mercado, os tribunais hesitam em opinar sobre o julgamento dos diretores da companhia-alvo. Assim, os tribunais tendem a permitir que a diretoria da companhia-alvo resista a aquisições hostis por meio da poison pill ou de outro modo" Tradução livre.

${ }^{328}$ Ibid. p. 383. "Um terceiro modo de superar a poison pill é por meio da disputa por procurações outorgadas pelos acionistas da companhia-alvo, a fim de se remover seus diretores e substituí-los por um grupo simpático à oferta" Tradução livre.

${ }^{329}$ COMPARATO, Fábio Konder; FILHO, Calixto Salomão. Op. cit., p. 250.
} 
"Do ponto de vista puramente cível, tal cláusula seria de validade extremamente duvidosa, em face da vedação legal das condições meramente potestativas (artigo 122, $2^{\mathrm{a}}$ parte, do Código Civil de 2002). Através dessa técnica, se cogita da inserção da sociedade em um dos pólos do negócio jurídico (como emissora de ações ou devedora de debêntures) realizado necessariamente em condições favoráveis aos adquirentes para interferir na compra e venda. O potencial prejuízo que poderia ser causado por um futuro adquirente não parece ser suficiente a justificar o dano incorrido no negócio jurídico realizado com a sociedade" ${ }^{, 30}$.

Por estas razões, ambos os autores concluem que a utilização da poison pill, em muitas ocasiões, supera os limites da business judgment rule: regra de interpretação dos negócios sociais, a que nos referimos no capítulo 1 deste estudo, permitindo-se que se questione a utilização do instrumento por parte dos administradores da companhia-alvo. Em determinadas circunstâncias, possibilita-se sujeitá-los ao regime de responsabilidade previsto na hipótese de atuação contrária ao melhor interesse da sociedade ${ }^{331}$. Em todas as hipóteses, restaria aos administradores da companhia-alvo observar o dever de fidúcia inerente ao office ocupado e na qualidade de agentes indicados para atender aos interesses de seus principais no melhor exercício da companhia, conforme discutiu-se ao longo dos itens 3.3 e 3.4 deste trabalho.

Apresentadas as principais espécies que compõem as categorias de estratégias ex-post ou estruturais de defesa à tomada de controle acionário e as estatutárias ou previstas ex-ante à realização da oferta pelo controle, bem como outros dois dos principais elementos que integram o estudo da transferência de controle na sociedade anônima: o prêmio pelo controle social e a discussão pela desejabilidade econômico-social de sua transferência, passa-se à última etapa deste ensaio. O estudo das duas modalidades de transferência de controle na sociedade anônima: a cessão de controle acionário

\footnotetext{
${ }^{330}$ Ibid. p. 251.

${ }^{331}$ Explicam os autores: "No conflito entre um interesse potencial e futuro e um interesse patrimonial atual, parece que a atuação do administrador favorável ao primeiro supera os limites da business judgment rule, caracterizando concreto descumprimento do dever de atuação no interesse da sociedade, previsto no art. 154, caput, da Lei $\mathrm{n}^{\circ} 6.404 .76$ e, conseqüentemente, induz à sua responsabilidade nos termos do art. 158, II da mesma lei. A admissibilidade e efetividade dessa poison pill no direito brasileiro é, portanto, no mínimo, bastante duvidosa” Ibid. p. 251.
} 
e a oferta pública à sua aquisição, bem como a discussão sobre a configuração da alienação de controle acionário no direito brasileiro é realizado no quinto e último capítulo seguinte desse ensaio. 


\section{Capítulo 5 - A transferência de controle na sociedade anônima}

\subsection{A cessão do controle acionário: natureza e caracterização}

"Os problemas nascidos da cessão de controle ainda não são todos conhecidos; poucos são perfeita e fundamentalmente analisados. Um largo campo de ação abriu-se, assim, à prática; ela não esgotou todas as suas possibilidades. Um vasto setor de reflexão ofereceuse, por igual, à doutrina. Estamos num desses domínios privilegiados onde, encontrando-se as coisas em seu começo, a pesquisa jurídica deve exercer-se livremente, fora dos ucasses doutrinários, dos caminhos vazios da rotina e das jurisprudências por demais constantes para serem convincentes" ${ }^{332}$ (Claude Champaud, 1962).

Os fundamentos da cessão de controle acionário na sociedade anônima evidenciam tanto a sua importância na vida societária como as perplexidades dela decorrentes. Tamanha a relevância da operação, diante da dimensão que a cessão de controle habitualmente assume por sua extensão sobre os interesses relacionados ao exercício da sociedade anônima, que o estudo de sua natureza, de sua regulação proposta, e das conseqüências que de ambas advêm é imprescindível para a sua devida compreensão ${ }^{333}$.

Propõe-se realizar a análise da cessão de controle acionário em atenção a três elementos principais. Primeiro, discutem-se a natureza e os caracteres da operação, bem como as formas de sua realização. Ao longo desta seção, são apresentados, ainda, os principais aspectos regulatórios da cessão de controle no ordenamento brasileiro para, por fim e à luz dos problemas de agência utilizados como fundamento metodológico para a análise das relações decorrentes da transferência de controle, concluir-se o estudo em espécie da cessão do controle acionário.

\footnotetext{
${ }^{332}$ CHAMPAUD, Claude. Nouvelles Techniques de Concentración. p. 140. Ap. COMPARATO, Fábio Konder; FILHO, Calixto Salomão. Op. cit., p. 261.

${ }^{333}$ Discute Fábio Konder Comparato: "O que suscita a polêmica e acende as paixões é, sem dúvida, o caráter geralmente secreto, das negociações de cessão de controle e a magnitude dos valores" patrimoniais em causa”. Ibid. p. 261.
} 
Fábio Konder Comparato entende a natureza do negócio jurídico de cessão de controle acionário como de contrato sinalagmático comutativo que, muito embora nele possam figurar mais de dois sujeitos, envolve somente e necessariamente duas partes contratantes: o alienante do controle acionário e seu adquirente ${ }^{334-335}$.

A compreensão da realidade do poder de controle na sociedade anônima delineia o exato objeto de sua cessão. A alienação de $49 \%$ das ações votantes de uma companhia distingue-se da consistente em 51\%, não apenas pela parcela do capital social transacionado, mas sim pela alienação, na segunda hipótese, da maioria das ações votantes da companhia. Com ela, transfere-se o poder de controlar os negócios da sociedade anônima de que se é titular ${ }^{336}$. Entende-se que a cessão do controle acionário não se confunde com a cessão das ações que lhe correspondem, embora se lhe seja diretamente relacionada. Desta premissa decorre o debate sobre a quem deve ser atribuído o prêmio correspondente ao controle quando de sua alienação, ou melhor, o questionamento sobre a legitimidade do controlador em recebê-lo em lugar da companhia, conforme se discutiu no item 4.3.deste estudo.

\footnotetext{
${ }^{334}$ Ibid. p. 267.

335 À cessão de controle, aplicam-se, ainda, as disposições previstas no Código Civil sobre os defeitos do negócio jurídico. Diante da verificação de defeito de qualquer dos elementos que lhe são essenciais, no caso, ao negócio jurídico de cessão de controle acionário, é possível a anulação do negócio jurídico celebrado por ambos, cessionário e cedente. Assim sustenta Calixto Salomão Filho: "É importante ressaltar que para que o erro essencial ou mesmo o dolo por omissão leve à anulação é necessário, como expressamente estabelecido nos arts. 139 e 147 do Código Civil de 2002, que eles se refiram a elementos essenciais do negocio. Aplicam-se as observações feitas quanto aos vícios redibitórios que podem levar à anulação do negócio jurídico. (...) Caso a intenção seja a manutenção da organização, esta e seu funcionamento são os elementos essenciais. Caso, por outro lado, um bem (ou um conjunto de bens) material ou imaterial em especial seja o objeto mediato da aquisição, defeitos de funcionamento destes são essenciais para a anulação”. COMPARATO, Fábio Konder; FILHO, Calixto Salomão. Op. cit., p. 289.

${ }^{336}$ Justifica Fábio Konder Comparato: "É nesse ponto que aparece a realidade específica do poder de controle societário, inconfundível com as próprias ações cedidas (...) Essa diferença de $2 \%$ não é apenas numérica, pois importa a alienação de outro bem econômico, diverso dos títulos acionários”. Ibid. p. 268.
} 
O sentido da expressão ‘cessão de controle acionário' evidencia a compreensão das condições em que a operação tem lugar. A contratação da cessão do controle é realizada quando se destaca do capital social da companhia um bloco de ações representativo do capital votante, cuja obtenção implique na aquisição do controle acionário majoritário. Assim, em situações em que não haja um bloco de controle acionário passível de distinção, de titularidade una ou exercido por meio de acordo de acionistas, a cessão de controle acionário perde seu objeto primo aos olhos do adquirente. Disto resultam as diferenças entre os conflitos de agência decorrentes da cessão de controle acionário e da oferta pública à sua aquisição em dois de seus principais elementos: as partes relacionadas à operação e o seu objeto. Justifica-se a regulação específica de cada uma dessas modalidades de transferência de controle acionário, bem como o estudo em separado de ambas as operações que aqui se propõe, em atenção aos conflitos ou problemas de agência decorrentes de cada uma.

Diante da relevância e da complexidade da cessão do controle acionário frente aos interesses das partes contratantes e ao exercício da companhia, é comum que a realização da operação se dê por meio de etapas sucessivas. Pode-se, assim, classificar a cessão de controle acionário de acordo com a forma de sua concretização: se realizada num momento específico (monofásica), ou de forma diferida (plurifásica). Fábio Konder Comparato destaca a possibilidade de se pactuar, como etapa preliminar à efetiva cessão de controle, a promessa em contratá-la, seguida por sua realização. A conveniência da realização de um contrato preliminar à celebração do instrumento de cessão de controle acionário encontra-se no fato de que os promitentes da cessão podem não disponibilizar $a b$ initio todas as informações necessárias para pactuarem os exatos termos sobre os quais desejam que se realize a cessão do controle acionário. Útil, assim, a prescrição de obrigações 
específicas, que materializem os termos sob os quais cedente e cessionário desejam realizar a cessão do controle ${ }^{337}$.

Em acréscimo aos interesses das partes contratantes da cessão de controle acionário, ou de seus agentes, de acordo com a leitura funcional da operação, a sua compreensão para o exercício da sociedade anônima em suas diversas dimensões relaciona-se, ainda, aos interesses de credores, empregados e da própria sociedade compreendida como um todo, diante da relevância social da atividade empreendida por meio da companhia e conforme se conclui ao final dessa seção. Com relação aos sujeitos, pode-se classificar os interesses referentes à cessão de controle acionário em 'subjetivamente imediatos' e 'subjetivamente mediatos', ou, de acordo com a leitura da cessão de controle sob os problemas de agência na sociedade anônima, se correspondentes aos agentes ou aos principais da operação. Evidenciam-se os problemas de agência relacionados ao contraste entre os interesses subjetivamente imediatos, ou dos 'agentes' da cessão de controle acionário (cedente e cessionário), e os mediatos, ou referentes às demais partes contratantes com a sociedade, tais como de acionistas minoritários, de acionistas preferencialistas sem direito de voto, de credores, empregados e, ainda, da sociedade como um todo. Fábio Konder Comparato e Calixto e Calixto Salomão Filho destacam duas das seis esferas subjetivas que, inicialmente, se pode identificar como integrantes dos interesses subjetivamente mediatos à operação ${ }^{338}$ : o interesse dos trabalhadores pela

\footnotetext{
337 A respeito do entendimento jurisprudencial manifestado pelo Supremo Tribunal Federal no julgamento do RE $n^{\circ}$ 88.716, Fábio Konder Comparato critica a exigência realizada de que, no contrato preliminar de cessão de controle acionário, deva constar todos os elementos essenciais ao definitivo, para que se permita a sua execução específica, pois: "a determinação do contrato preliminar refere-se ao seu objeto direto, que é o contrato definitivo a ser celebrado; não ao conteúdo deste, que são as obrigações finais a serem pactuadas. Quanto a estas, basta que haja determinabilidade de seu objeto, isto é, das prestações recíprocas". COMPARATO, Fábio Konder; FILHO, Calixto Salomão. Op. cit., p. 286/287.

${ }^{338}$ As seis dimensões subjetivas que se pode identificar, cujos interesses relacionados à cessão de controle acionário foram identificados como passíveis de tutela $a b$ initio, são compostas pelos
} 
preservação dos postos de trabalho após a concretização da operação ${ }^{339} \mathrm{e}$, em se tratando de sociedades cujo funcionamento dependa de autorização da administração pública, do interesse do próprio poder público à sua realização ${ }^{340}$. À luz da natureza dos instrumentos regulatórios e de governança apresentados no item 3.4 desse estudo, observa-se que, para a tutela dos interesses subjetivamente mediatos à cessão de controle e, mais especificamente, a fim de se reduzir os custos de agência relacionados aos distintos interesses que agentes e principais possam apresentar na realização da operação, podem ser utilizadas desde estratégias de representação dos empregados e dos minoritários no conselho de administração da companhia, conforme, no direito brasileiro, prevê o parágrafo único do artigo 140 da Lei $6.404 / 76^{341-342}$, até a previsão legal de solidariedade passiva do adquirente do

interesses dos minoritários, dos preferencialistas, dos credores, dos empregados, da sociedade como um todo e do governo, em se tratando de sociedade cujo funcionamento dependa de autorização pelo poder público. Ressalva-se que se distingue, em categorias específicas, os interesses de minoritários e preferencialistas sem direito de voto, na medida em que os direitos conferidos às suas respectivas participações podem ser diversos, no caso de alienação de controle acionário. Conforme faculta a Lei $\mathrm{n}^{\circ}$ 6.404/76, em seus artigos. 15, $\S 2^{\circ}$, e 254-A e discutidos no item 5.3 deste capítulo. Respectivamente: "As ações, conforme a natureza dos direitos ou vantagens que confiram a seus titulares, são ordinárias, preferenciais, ou de fruição. $O$ número de ações preferenciais sem direito a voto, ou sujeitas a restrição no exercício desse direito, não pode ultrapassar 50\% (cinquienta por cento) do total das ações emitidas". E "A alienação, direta ou indireta, do controle de companhia aberta somente poderá ser contratada sob a condição, suspensiva ou resolutiva, de que o adquirente se obrigue a fazer oferta pública de aquisição das ações com direito a voto de propriedade dos demais acionistas da companhia, de modo a lhes assegurar o preço no mínimo igual a $80 \%$ (oitenta por cento) do valor pago por ação com direito a voto, integrante do bloco de controle".

$339^{\circ}$ A respeito da tutela conferida aos empregados da companhia diante da cesssão de controle acionário, dispõe Fábio Konder Comparato: "O custo social da operação vem sendo sempre encoberto pela discussão de outros aspecto, concernentes aos interesses dos acionistas não-controladores. Parece, por conseguinte, imprescindível que se ponham em pratica, desde logo, medidas efetivas de readaptação e recolocação dos empregados afetados por uma alteração substancial na empresa, conseqüente à mudança de controle, repartindo-se, adequadamente, os ônus econômicos dessas medidas". Ibid. p. 284.

${ }^{340}$ Assim coloca Calixto Salomão Filho: "Se a personalidade do controlador é, necessariamente, levada em consideração quando da autorização para o funcionamento da empresa, não faz senso dispensa-la quando há substituição da pessoa do controlador, no curso da exploração empresarial". Ibid. p. 285.

341 É importante ressalvar que, segundo o ordenamento jurídico brasileiro, a representação dos empregados na companhia é dispositiva, ou seja, de natureza facultativa, podendo ser prevista pelo estatuto social; enquanto a representação dos acionistas minoritários no conselho de administração da sociedae anônima é obrigatória, nos termos da Lei $n^{0}$ 6.404/76. Prescrevem os seus artigos 140, parágrafo único, e $141, \S 4^{\circ}$, respectivamente: "O estatuto poderá prever a participação no conselho de 
controle com relação aos débitos fiscais e trabalhistas de responsabilidade de seu antecessor na gestão dos negócios sociais da controlada ${ }^{343}$.

Por ora, restringindo-se à análise dos interesses específicos das partes contratantes na celebração da cessão do controle acionário, pode-se sustentar que, diante da companhia e de sua natureza contínua, como instrumento concebido para o desenvolvimento da atividade empresarial e, mais especificamente, para a realização de seu objeto, deve-se compreender como legítima a contratação, pelo cedente, de obrigações relacionadas à continuidade regular do exercício da empresa pela e sob a companhia controlada. É possível que se contrate, como parte integrante da consideration $^{344}$ a ser recebida pelo cedente, em contrapartida à cessão do controle acionário, obrigações acessórias à cessão de controle que digam respeito à continuidade da atividade econômica objeto da sociedade anônima, mesmo que relacionadas a momento posterior à efetivação da cessão do controle acionário e em acréscimo ao valor pecuniário recebido ${ }^{345-346}$. A tais

representantes dos empregados, escolhidos pelo voto destes, em eleição direta, organizada pela empresa, em conjunto com as entidades sindicais que os representem" e "Terão direito de eleger e destituir um membro e seu suplente do conselho de administração, em votação em separado na assembléia-geral, excluído o acionista controlador, a maioria dos titulares, respectivamente I - de ações de emissão de companhia aberta com direito a voto, que representem, pelo menos, $15 \%$ (quinze por cento) do total das ações com direito a voto; e II - de ações preferenciais sem direito a voto ou com voto restrito de emissão de companhia aberta, que representem, no mínimo, $10 \%$ (dez por cento) do capital social, que não houverem exercido o direito previsto no estatuto, em conformidade com o art. $18 ”$.

${ }^{342}$ Paul Davies e Klaus Hopt destacam a singularidade do regime representativo na sociedade anônima previsto no ordenamento holandês. Conforme destacam os autores, em companhias com mais de cem empregados, a target-board é obrigada a consultar um conselho constituído por representantes dos empregados. Nota-se que este modelo eleva os custos de agência correspondentes à transferência de controle acionário, na medida em que os representantes dos empregados atuarão como agentes dos principais, diretamente relacionados à cessão contratada e que dependem do consentimento do órgão representativo dos empregados para concretização do negócio pactuado. DAVIES, Paul; HOPT, Klaus. Op. cit., p. 188.

${ }^{343}$ No caso do direito do trabalho, com o objetivo de realizar essa tutela, prevê o art. 10 do Decreto $n^{\circ}$ 5.452, de $1^{\circ}$ de maio de 1943: a Consolidação das Leis do Trabalho: "Qualquer alteração na estrutura jurídica da empresa não afetará os direitos adquiridos por seus empregados”.

${ }^{344}$ CLARKON, Kenneth. Op. cit., p. 243 e ss.

${ }^{345}$ É esse o entendimento de Fábio Konder Comparato. Para tanto, o autor remete ao caso em que a Corte de Cassação francesa decidiu favoravelmente ao alienante do controle social que, mesmo acordado o prosseguimento da sociedade e de sua empresa, no caso, uma cervejaria alsaciana, o 
interesses correspondentes à operação, embora colaterais à sua realização, pode-se subclassificá-los como 'subjetivamente imediatos em sentido amplo', enquanto aos especificamente relacionados ao objeto principal da cessão contratada, no caso, o controle, por parte do cessionário, e o recebimento de seu valor correspondente, sob a ótica do cedente, e que podem ser denominados 'subjetivamente imediatos em sentido estrito'347. No ordenamento jurídico brasileiro, é importante ressalvar que, por imposição legal, a contratação do negócio jurídico de cessão de controle acionário que, por sua natureza, configura a alienação de controle, somente pode ser realizada sob a condição suspensiva ou resolutiva de que o adquirente se obrigue a realizar a oferta pública de aquisição das ações com direito ao tagalong e que não integram o bloco de controle objeto da cessão ${ }^{348}$. Conforme explica Nelson Eizirik:

"Na condição suspensiva, de rara ocorrência na prática dos negócios, os efeitos do contrato de alienação do controle ficam suspensos até a realização da oferta pública. Jána

adquirente posteriormente à sua aquisição liquidou a sociedade, encerrando as atividades de sua respectiva fábrica. Ibid. p. 287.

${ }^{346}$ As reformas ao Código de Processo Civil, promovidas através das Leis no 11.232 e 11.382 , respectivamente datadas de 22 de dezembro de 2005 e 6 de dezembro de 2006, prescrevem a regra de concessão de tutela específica às obrigações de fazer. Restringiu-se a resolução da obrigação pactuada em perdas e danos, remédio em regra cabível segundo o regime executivo revogado, aos casos de impossibilidade de cumprimento da obrigação. Diante das características da cessão de controle acionário e das obrigações que possam ser eventualmente pactuadas em razão do interesse do cedente na continuidade das atividades desenvolvidas pela companhia, infere-se a adequação do novo regime executivo às obrigações de fazer previsto no Código de Processo Civil à operação de cessão de controle.

${ }^{347}$ A pertinência prática da classificação proposta em duas categorias no que tange aos interesses subjetivamente imediatos referentes à cessão de controle, em sentido amplo e estrito, relaciona-se à classificação tradicional das obrigações em principais e acessórias, no que tange ao negócio jurídico de cessão de controle. Caio Mário da Silva Pereira entende que uma obrigação é principal "quanto tem existência autônoma independente de qualquer outra. E é acessória quando "não tendo existência em si, depende de outra a que adere ou cuja sorte depende". Assim, para se definir o regime jurídico correspondente às obrigações pactuadas no instrumento de cessão de controle acionário, deve-se ter em vista a sua natureza. No caso, se a referida obrigação é classificável como principal ao negócio jurídico pactuado, por exemplo, o próprio controle ou o preço pago em sua função, ou àquele acessório, como, por exemplo, a multa prevista no caso de mora no pagamento do preço pactuado. PEREIRA, Caio Mário da Silva. Instituições de Direito Civil - Teoria Geral das Obrigações. Vol. II, 20ª Ed.. Rio de Janeiro: Editora Forense, 2005. p. 120/122.

${ }^{348}$ EIZIRIK, Nelson Tema de Direito Societário. Rio de Janeiro: Editora Renovar, 2005. p. 243. 
condição resolutiva, as partes desde logo executam o contrato, tornando-se porém nulo o negócio jurídico caso o adquirente não promova a oferta pública" ${ }^{349}$.

Outra característica peculiar à cessão do controle acionário é a sua distinção frente à transferência da organização empresarial, afinal: “a empresa não pertence ao controlador" ${ }^{350}$. É distinto o aviamento criado e gerido pela e sob a sociedade anônima, de seu controle, entendido como a capacidade de direcionar os negócios sociais e discutido nas primeiras duas etapas deste estudo. Por isso, quando a cessão de controle empresarial constitui uma primeira etapa à cessão da empresa em si, como, por exemplo, no caso de cessão com subseqüente incorporação da sociedade-alvo, é ilícito atribuir ao controlador-cedente um valor que contemple, além do controle, o representativo da empresa constituída ${ }^{351}$. Conforme dispõe o artigo 109, II, da Lei $n^{0}$ 6.404/76, é direito essencial de todos acionistas participar do acervo social nos casos de liquidação. Assim, são distintos os regimes aplicáveis e o modo de contabilização da participação respectiva a cada acionista nas hipóteses de extinção da sociedade às de transferência do controle acionário, conforme se observou no item 4.3 deste estudo e se discute na última seção deste capítulo, quando é analisado o entendimento da Comissão de Valores Mobiliários - CVM, sobre a configuração da alienação de controle acionário e a atribuição do direito de saída previsto no artigo 254-A, da Lei das Sociedades por Ações, aos acionistas com direito ao tag-along.

Retorna-se, por fim, à questão que permeia o objeto deste trabalho. Além dos interesses subjetivamente imediatos nos sentidos amplo e estrito, ou de ambas as partes contratantes da operação: a obtenção do controle acionário, no caso do cessionário, e a percepção da consideration ou contrapartida à

\footnotetext{
${ }^{349}$ Ibid. p. 243.

${ }^{350}$ Ibid. p. 313.

${ }^{351}$ A esse respeito, Fábio Konder Comparato aponta o direito individual de participação no acervo da sociedade anônima como essencial a todos os acionistas: controladores ou não. Assim dispõe o inciso II, do art. 109, da Lei 6.404/76: "Nem o estatuto social nem a assembléia-geral poderão privar o acionista dos direitos de participar do acervo da companhia, em caso de liquidação”. Ibid. p. 313.
} 
cessão realizada, no tocante ao cedente, existem interesses outros ou subjetivamente mediatos à companhia que merecem ser tutelados pelo direito na realização da operação. Em caso afirmativo, resta, ainda, ponderar a tutela a tais interesses vis à vis os custos de agência e de transação relacionados à previsão destes instrumentos à atividade econômica organizada sob e pela companhia. Ao final, é tão-somente à luz das características de cada sistema jurídico e da realidade econômica peculiar a cada modelo regulatório que se é possível afirmar se as reações adversas do remédio que se pretende prescrever à hipótese em questão são mais gravosas do que a patologia que se pretende curar. No ordenamento jurídico brasileiro, a análise dos fundamentos de cada um dos instrumentos de tutela dos interesses subjetivamente mediatos previstos para os 'principais' da cessão de controle acionário demanda um estudo específico e, por isso, opta-se por realizá-lo numa outra ocasião.

Apresentados os principais elementos que compõem a primeira modalidade de transferência de controle acionário classificada por Paul Davies e Klaus Hopt na categoria 'transações de controle' discutida no item 4.1 deste trabalho, passa-se ao estudo de sua segunda categoria: a oferta pública de aquisição.

\subsection{A oferta pública de aquisição de controle acionário: natureza e caracterização}

"The maximum number of takeovers is likely to be generated by a system which enjoins upon target management a rule of passivity in relation to actual or threatened takeovers (first dimension) and which gives the acquirer the maximum freedom to structure its bid (the second dimension)" 352 (Paul Davies e Klaus Hopt, 2005).

\footnotetext{
${ }^{352}$ DAVIES, Paul; HOPT, Klaus. Op. cit., p. 189. “O maior número de tomadas de controle é passível de ser gerado provavelmente por um sistema que imponha à administração da companhia-alvo uma regra de passividade na condução da oferta pública pela aquisição do controle acionário (primeira dimensão) e que atribua ao adquirente a maior liberdade para estruturar a oferta (segunda dimensão)" Tradução livre.
} 
A oferta pública de aquisição de controle acionário ocorre quando o proponente (agente) busca, por meio da realização de oferta aos acionistas da sociedade anônima (principais), adquirir um número de ações suficiente a lhe atribuir o controle da companhia-alvo ${ }^{353-354}$. Distintamente da cessão do controle acionário, os conflitos de agência que se originam da relação entre as partes constituintes da companhia-alvo frente ao ofertante do controle acionário evidenciam as peculiaridades desta modalidade de transferência de controle ${ }^{355-356}$.

Conforme destaca Nelson Eizirik, a natureza jurídica da oferta pública de aquisição de controle - OPA para aquisição, é de declaração unilateral de vontade. É por meio do instrumento que formaliza a OPA para aquisição que "o proponente manifesta, por determinado prazo, seu compromisso de adquirir um bloco de ações a um preço determinado e segundo cláusulas e condições previamente estabelecidas" $357-358$.

\footnotetext{
${ }^{353}$ Ibid. p. 157.

${ }^{354}$ Kenneth Clarkson localiza a oferta pública à tomada de controle dentro das operações relacionadas à existência da sociedade anônima: "When the acquiring corporation makes a public offer to all shareholders of the target corporation, it is called a tender offer" CLARKSON, Kenneth, Op. cit., p. 812. "Denomina-se oferta pública de aquisição de controle a operação em que a companhia adquirente faz uma oferta pública a todos acionistas da companhia-alvo" Tradução livre.

${ }^{355}$ Nos itens 4.4 e 5.1 desse estudo, foram discutidos os fundamentos da distinção entre os interesses dos participantes da sociedade anônima na cessão de controle acionário e na oferta pública à sua aquisição. Essa dissociação relaciona-se ao fato de que, enquanto a cessão de controle acionário prescinde da anuência do(s) acionista(s) titular(es) das ações que compõem o bloco de controle, a oferta pública à aquisição tem lugar quando não é possível buscar a cessão de controle acionário em virtude do grau de dispersão do capital acionário da companhia-alvo. As características da operação são comentadas ao longo desse item.

356 Conforme delimitado no item 4.1, por razões metodológicas peculiares aos problemas de agência existentes na sociedade anônima, este estudo limita-se à análise das operações de transferência de controle em que figure um terceiro estranho à sociedade, mas que pode a ela pertencer: a cessão do controle acionário e a oferta pública à sua aquisição. Deixa-se, assim, a observação de operações deliberadas internamente à companhia, tais como fusão, cisão, incorporação, alienação de parcela relevante dos ativos da companhia, bem como dos conflitos de agência delas decorrentes, para um outro momento.

${ }^{357}$ EIZIRIK, Nelson; Mercado de Capitais - Regime jurídico. $2^{\mathrm{a}}$ Ed. Rio de Janeiro: Editora Renovar, 2008. p. 551. Apud. CARVALHOSA, Modesto, Oferta pública de aquisição. Rio de Janeiro, IBMEC, 1979 , p. 24.

358 A Instrução CVM n ${ }^{\circ} 361$, de 5 de março de 2002, enuncia, em seu artigo 10, os requisitos essenciais do instrumento de OPA.
} 
A oferta pública de aquisição de controle é distinta, ainda, da realizada na alienação de controle de companhia aberta. Sob a regulação brasileira de ambas as ofertas e como se estuda ao final deste capítulo, enquanto a primeira é, por sua natureza, facultativa, pois realizada por aquele que visa à aquisição do controle da sociedade-alvo, a decorrente da alienação de controle acionário é compulsória ao seu adquirente, pois decorre de obrigação legal, como contrapartida à alienação de controle promovida, por exemplo, por meio de $\operatorname{cessão}^{359}$.

Kenneth Clarkson destaca o caráter estratégico-negocial da oferta pública à aquisição de controle acionário. Conforme comenta, uma alternativa à aquisição de ativos da companhia-alvo que interessem ao adquirente é a compra de ações representativas de seu capital social em número suficiente para possibilitar a aquisição de seu controle ${ }^{360}$. Em contrapartida, conforme se discutiu no item 4.4 deste estudo, a venda da crown jewel, estratégia de defesa à tomada de controle que consiste na alienação de bem que integre o ativo da companhia-alvo, e que se sabe motivou o adquirente a obter o seu controle, visa a combater justamente o fundamento que estimulou o proponente a ofertar a aquisição do controle da companhia-alvo. Ressalva-se que, no ordenamento brasileiro, salvo disposição estatutária em contrário, compete ao próprio conselho de administração autorizar a alienação dos bens que integram o ativo permanente da sociedade anônima ${ }^{361}$.

Por ocorrer no mercado, a oferta pública de aquisição aproxima-se, ainda, do que se denomina 'escaladas societárias' e que, inicialmente, podem

\footnotetext{
${ }^{359}$ EIZIRIK, Nelson. Temas de Direito Societário. Rio de Janeiro. Editora Renovar, 2005. p. 231.

${ }^{360}$ Kenneth Clarkson define a tomada de controle como: "The process of acquiring control over a corporation (...) through "the purchase of a substantive number of the voting shares of its stock" CLARKSON. Kenneth W. et. al. Op. cit., p. 812. "Processo de aquisição da companhia-alvo (...) através da compra de parcela substantiva de seu capital votante" Tradução livre.

${ }^{361}$ Assim dispõe o artigo 142, VIII, da Lei das Sociedades por Ações: "Compete ao conselho de administração: autorizar, se o estatuto não dispuser em contrário, a alienação de bens do ativo permanente, a constituição de ônus reais e a prestação de garantias a obrigações de terceiros".
} 
ser entendidas como uma terceira modalidade de transferência de controle compreendidas na categoria 'transações de controle', classificada por Paul Davies e Klaus Hopt, à luz dos problemas de agência na sociedade anônima $^{362}$.

Conforme se discutiu no item 4.1 deste trabalho, são inicialmente três as modalidades de transferência de controle que integram a categoria 'transações de controle' proposta pelos autores, pois em todas as suas modalidades figura um terceiro adquirente frente à companhia e aos seus acionistas: a cessão de controle acionário, a aquisição do controle realizada mediante a compra em negociações privadas de porções do capital social da companhia-alvo no mercado secundário; e a aquisição obtida por meio de uma oferta pública, com ou sem o suporte da target-board ${ }^{363}$.

Preliminarmente, nota-se que a venda do bloco de ações que representa o controle, ou a cessão do controle acionário discutida na primeira parte deste capítulo, é somente uma modalidade de sua transferência. Na verdade, a transferência de controle na sociedade anônima pode ser operada por meio de outras tantas formas. Observam Paul Davies e Klaus Hopt:

"A shift of control may take place quietly and without incident at the annual meeting or may occur in a stormy Proxy fight, a friendly tender offer or a fraudulent seizure. Control generally passes in the sale of majority stock ownership ${ }^{, 364}$.

A transferência de controle pode ser realizada imperceptivelmente no mercado, mediante a aquisição, pelo adquirente, de ações suficientes para lhe atribuir a titularidade do controle acionário, o que se chama 'escalada

\footnotetext{
${ }^{362}$ DAVIES, Paul; HOPT, Klaus. Op. cit., p. 158.

${ }^{363}$ Ibid. p. 158.

364 DAVIES, Paul; HOPT, Klaus. Op. cit., p.158. "A transferência de controle pode ocorrer silenciosamente na assembléia geral ordinária, em uma Proxy fight, por meio de uma oferta pública amigável pelo controle ou através da adoção de meios fraudulentos. O controle é geralmente transferido através da venda da parcela majoritária do capital votante da companhia" Tradução livre.
} 
acionária' $^{365}$. Assim, busca-se, privada e regulatoriamente, prescrever patamares de aquisição de participação acionária que, alcançando-os, gere ao adquirente a obrigação de informar o mercado ${ }^{366} \mathrm{e}$, em determinados ordenamentos, adquirir o restante do capital votante da companhia, sob determinadas condições ${ }^{367}$. Assim prevêem certas legislações estaduais nos Estados Unidos e as regulamentações germânica e portuguesa ${ }^{368}$. Tais instrumentos de tutela proporcionam aos acionistas um direito de saída e, por assim fazê-lo, elevam os custos da transferência de controle na sociedade anônima, com as conseqüências e fundamentos discutidos nos capítulos 3 e 4 deste ensaio.

A regulação da oferta pública de aquisição de controle adquire dimensões peculiares variáveis, conforme se denota da análise de sistemas jurídicos distintos ${ }^{369}$. Comumente, são poucos os modelos regulatórios que possuem uma normatização densa da oferta pública de aquisição de controle, restringindo-se à regulação de traços elementares da operação no bojo da estruturação dos aspectos gerais da sociedade anônima ${ }^{370}$. Não obstante,

\footnotetext{
${ }^{365}$ Ibid. p. 162.

366 No ordenamento jurídico brasileiro, a Comissão de Valores Mobiliários - CVM, impõe ao adquirente de determinada parcela do capital social votante da companhia, a obrigação de comunicá-la ao mercado por meio de fato relevante. Dispõe o artigo $1^{\circ}$, da Instrução $n^{\circ} 358$, de 3 de janeiro de 2002: "São regulados pelas disposições da presente Instrução a divulgação e o uso de informações sobre ato ou fato relevante, a divulgação de informações (...) na aquisição de lote significativo de ações de emissão de companhia aberta (...)".

${ }^{367}$ Paul Davies e Klaus Hopt destacam o caráter controverso da obrigatoriedade imposta ao adquirente de uma parcela do capital social de realizar uma oferta pública de aquisição da restante: "the strongest and most controversial expression of the sharing principle is the requirement that the acquirer of shares make a general offer to the other shareholders once it hás acquired sufficient shares by private contract (whether on or off market) to obtain the control of the target and that the offer be at the price highest paid for the controlling shares. This is the mandatory bid rule”. A expressão mais forte e controversa sobre o princípio da igualdade de oportunidades é a exigência feita ao adquirente de ações de fazer uma oferta geral aos outros acionistas, na medida em que tenha adquirido ações suficientes por meio de operações provadas (dentro ou fora do mercado) para adquirir o controle da companhiaalvo e que a oferta seja feita pelo preço mais alto pago pelas ações referentes ao controle. Esta é a regra de oferta pública obrigatória”. DAVIES, Paul; HOPT, Klaus. Op. cit., p. 178.

${ }^{368}$ Ibid. p. 179.

${ }^{369}$ Ibid. p. 159.

${ }^{370}$ Exemplo dessa opção regulamentar é o modelo adotado nos Estados Unidos. Conforme destacam Paul Davies e Klaus Hopt: "The (federal) securities laws focus only on limited aspects of control
} 
mesmo nos ordenamentos que apresentam uma regulação específica da transferência de controle na sociedade anônima ${ }^{371}$, Paul Davies e Klaus Hopt destacam que, tradicionalmente, deixa-se, a cargo do ordenamento societário genericamente observado, a regulação subsidiária da transferência de controle naquilo em que seja silente ${ }^{372}$.

As circunstâncias que delineiam as características da regulação da oferta públicas de aquisição do controle podem ser classificadas em duas: a sua regulação em contextos em que prevalecem companhias com capital estrutura concentrada de capital e dispersa. Para fins metodológicos relacionados à observação dos problemas de agência discutidos no item 3.4 deste estudo e presentes na realização da OPA para aquisição de controle, assume-se, como modelo teórico, a companhia-alvo com capital disperso, na qual, diante da distribuição do capital votante por um certo número de acionistas, não é possível identificar um bloco de ações que corresponda ao controle majoritário. Conforme se observou na classificação do controle realizada no item 2.3 deste trabalho, na hipótese em questão - de controle minoritário ou gerencial, nenhuma parcela do capital votante da companhia, necessariamente, corresponde ao controle ${ }^{373}$.

trasactions. Substantial areas of regulation are left to (state) corporation laws, both common law and statutory, which may apply to both publicly traded and closely held corporations". DAVIES, Paul; HOPT, Klaus. Op. cit., p. 159. “A legislação federal sobre valores mobiliários foca-se em aspectos restritos das transações de controle. Áreas substanciais da regulação são deixadas à regulação estadual da sociedade anônima, por meio da normatização de origem na Common Law e do direito estatutário, que pode ser aplicável às companhias abertas e fechadas" Tradução livre.

371 Assim as diferencia o caput do art. $4^{\circ}$, da Lei 6.404, de 1976: "Para os efeitos desta Lei, a companhia é aberta ou fechada conforme os valores mobiliários de sua emissão estejam ou não admitidos à negociação no mercado de valores mobiliários”. Para os fins deste estudo, a classificação das companhias em abertas e fechadas é relevante para se delimitar o alcance das normas previstas na regulação da transferência de controle na sociedade anônima.

${ }^{372}$ DAVIES, Paul; HOPT, Klaus. Op. cit., p. 162.

${ }^{373}$ Paul Davies e Klaus Hopt assumem a hipótese com a mesma finalidade: distinguir os conflitos de agência decorrentes da transferência de controle em companhias de capital disperso (sem bloco majoritário de ações que represente o controle), dos existentes em companhias com o controle concentrado, em razão da estrutura de seu capital. DAVIES, Paul; HOPT, Klaus. Op. cit., p. 159. 
Diante das características da oferta pública de aquisição de controle, de realização facultativa no ordenamento jurídico brasileiro, Nelson Eizirik a define como:

"Aquela mediante a qual o ofertante pretende, por meio da aquisição das ações pertencentes a diversos acionistas, assumir o controle de determinada companhia que não possua um acionista ou grupo controlador previamente definido",374.

Em sociedades com estrutura de capital disperso, espera-se que o ofertante busque adquirir o controle acionário mediante a adoção de duas estratégias sucessivas. Na primeira etapa da operação, o adquirente busca comprar ações votantes da companhia-alvo no próprio mercado secundário para, em seguida, realizar uma oferta pública de aquisição direcionada aos acionistas da companhia cujo controle deseja ${ }^{375}$. Dependendo do grau de dispersão do capital social votante (e assim assumido como modelo), não é incomum que o controle de fato da companhia seja exercido por seus administradores, configurando-se o controle gerencial, tal qual classificado por Adolf Berle e Gardiner Means e discutido no item 2.3 deste estudo ${ }^{376}$. Assim, caso o adquirente suceda em sua oferta, diante da aceitação por acionistas que detenham parcela do capital social votante suficiente à obtenção do controle de facto por parte do adquirente, perdem-no os administradores. É possível, portanto, que se opere a dissociação entre os destinatários da oferta pública de aquisição, os acionistas, e os titulares cujo controle de fato é transferido, os administradores da sociedade anônima de capital disperso. Evidencia-se a primeira perplexidade no que tange à regulação da oferta pública de aquisição, qual seja, a possibilidade de adoção,

\footnotetext{
${ }^{374}$ EIZIRIK, Nelson; Mercado de Capitais - Regime jurídico. $2^{\text {a }}$ Ed.. Rio de Janeiro: Editora Renovar, 2008. p. 552.

${ }^{375}$ DAVIES, Paul; HOPT, Klaus. Op. cit., p. 160.

${ }^{376}$ Conforme se discutiu no item 2.3. deste estudo, segundo a classificação proposta por Adolf Berle e Gardiner Means, as modalides de controle interno são o controle exercido através da quase integral propriedade acionária; o controle majoritário; o controle exercido mediante expedientes legais; o controle minoritário; e o controle administrativo ou gerencial.
} 
por parte dos administradores da companhia-alvo, de estratégias de defesa à tomada de controle admitida no modelo regulamentar norte-americano e discutida no final do capítulo $4^{377}$.

Mais ainda, alcança-se o debate sobre o tratamento que se deve atribuir aos participantes minoritários da companhia. Em outras palavras, busca-se analisar a natureza e as conseqüências da utilização da estratégia de governança 'direito de saída', classificada por Henry Hassmann e Reinier Kraakman, em sua leitura funcional das relações societárias como categoria integrante do par 'termos de afiliação' na sociedade anônima e discutida no item 3.4 deste ensaio. A respeito dos direitos atribuíveis na oferta pelo controle e, especificamente no que tange à oferta pública de sua aquisição, Paul Davies e Klaus Hopt questionam:

"Must all offerees receive the same offer, so that two-tier bids are prohibited? Must those who accept offers be treated equally with those who have sold their shares to the acquirer outside the formal offer? Should partial offers be allowed? And, most controversial of all, should persons who have acquired certain percentages of a company's voting shares be required to offer for the remainder and at what price?"378

Primeiro, é racional que, econômica e estrategicamente, o adquirente ofereça valor maior àqueles acionistas cujas participações lhe confira o controle de facto da companhia. Aos demais, caso se lhe imponha a obrigação legal de também adquirir as ações que não as que lhe conferiu o controle de

\footnotetext{
${ }^{377}$ Explicam Paul Davies e Klaus Hopt: "Therefore, there is a disjunction between the parties to the dealings which bring about the transfer of control (acquirer and target shareholders) and the parties to the control shift itself (acquirer and target board). It's precisely this disjunction which generates specific agency problems". DAVIES, Paul; HOPT, Klaus. Op. cit., p.160. "Assim, ocorre uma dissociação entre as partes relacionadas às operações que materializam a transferência do controle (adquirente e acionistas da companhia-alvo) e as partes entre as quais o controle é transferido (adquirente e administradores da companhia-alvo). É precisamente esta dissociação que gera problemas de agência específicos" Tradução livre.

${ }^{378}$ DAVIES, Paul; HOPT, Klaus. Op. cit., p. 177. "Todos os acionistas da companhia-alvo devem ou não receber a mesma oferta, de modo que ofertas realizadas por valores distintos devam ser proibidas? Aqueles que aceitam a oferta realizada pelo adquirente devem ser tratados igualmente aos que tenham vendido as suas ações externamente à oferta pública de aquisição realizada? Ofertas parciais devem ser permitidas? E ainda mais controverso: indivíduos que tenham adquirido determinados percentuais do capital votante da companhia devem ser obrigados a adquirir o restante do capital votante? E, caso afirmativo, por qual preço?” Tradução livre.
} 
facto, espera-se que, a partir da aquisição do percentual do capital social votante da companhia que propicie o controle da companhia-alvo, o adquirente ofereça aos demais acionistas um valor menor por suas respectivas participações no capital social ${ }^{379}$. À luz dos mesmos fundamentos que os apresentados na discussão da repartição do prêmio correspondente ao controle e aqui realizado no item 4.3, entende-se que qualquer regulação que imponha a extensão da oferta aos demais acionistas que não os controladores e que, ao assim fazer, eleve o custo da operação ao adquirente, é restritiva à realização de operações de transferência de controle na sociedade anônima. Desta forma, sugerem os autores que adotam aos pressupostos da análise funcional do direito como fundamento ao estudo da transferência de controle da sociedade anônima, a tutela que deve ser atribuída aos acionistas não-controladores da companhia-alvo não deve ir além à manutenção de sua situação econômica já existente no momento da transferência de controle na companhia.

Em seu lugar, pode acontecer que a pressão relacionada à aceitação de uma determinada oferta refira-se, não aos termos propostos aos titulares do capital votante da companhia-alvo, mas ao temor dos acionistas minoritários em continuar a integrar o capital da companhia após a efetivação da transferência de seu controle. Paul Davies e Klaus Hopt explicam que é comum que se busque solucionar esse problema exigindo-se que o adquirente do controle da companhia-alvo deixe a oferta aberta à aceitação por um período mínimo e que, ao longo de sua condução, informe ao mercado sobre o

\footnotetext{
379 Conforme destacam Paul Davies e Klaus Hopt: "In particular, the acquirer may pressurize shareholders of the target into accepting an offer (...), but in essence they all involve exploitation by the acquirer of the co-ordination problems which dispersed shareholders experience” DAVIES, Paul; HOPT, Klaus. Op. cit., p. 158. "Particularmente, o adquirente pode pressionar os acionistas da companhia-alvo para aceitarem uma determinada oferta, (...) mas, essencialmente, todos eles [os métodos utilizáveis] envolvem a exploração pelo adquirente dos problemas de coordenação que os acionistas experimentam” Tradução livre.
} 
andamento de sua aceitação pelos acionistas da companhia-alvo ${ }^{380}$. No entanto, mais eficiente que tal modelo, defendem os autores, seria obrigar o adquirente a estender a oferta por um período determinado logo e tão-somente após a constatação de ter sido bem-sucedida a oferta com a transferência do controle da companhia-alvo já operada em seu favor, e não por um período específico e independentemente do sucesso da oferta ${ }^{381}$. Dessa forma, restringe-se ao adquirente a possibilidade de pressionar os acionistas da companhia-alvo à aceitação da oferta por termos menos vantajosos que os pactuados em outras operações similares, valendo-se da incerteza destes, individualmente considerados, frente ao que a maioria do capital votante da target venha a decidir ${ }^{382}$. Conforme se notou no item 4.1, este déficit informacional não se apresenta, por exemplo, nas 'ações relevantes à sociedade anônima', na medida em que, nas operações que a integram, a tomada de decisão respectiva à operação ocorre internamente à própria companhia.

Assim, entendida a oferta pública à aquisição de controle em suas peculiaridades e diante do modelo funcional proposto à sua leitura, Paul Davies e Klaus Hopt explicam que a principal estratégia de governança utilizada para se endereçar aos conflitos de agência decorrentes da operação relaciona-se à alocação dos direitos de decisão referentes à oferta e, mais especificamente, da delimitação destes direitos entre administradores e $\operatorname{acionistas}^{383}$. De acordo com a classificação dos regimes jurídicos proposta no item 4.4 deste ensaio, qual seja, entre os sistemas que impõem ou não o dever de abstenção aos administradores da companhia-alvo na condução da OPA

\footnotetext{
${ }^{380}$ Em acréscimo a esses instrumentos de tutela, o direito italiano reserva aos acionistas remanescentes da companhia-alvo, no caso de mais de $90 \%$ de sua aceitação, o direito de serem "comprados", ou de, caso assim desejem, venderem as suas posições. DAVIES, Paul; HOPT, Klaus. Op. cit., p. 178.

${ }^{381}$ Ibid. p. $177 / 178$.

${ }^{382}$ Ibid. p. 161.

${ }^{383}$ Ibid. p. 162.
} 
para aquisição, pode-se destacar dois ordenamentos principais. O primeiro, adotado na City britânica, impõe aos administradores da companhia-alvo, a regra de passividade no curso de uma oferta à aquisição. Por meio desta técnica regulamentar, resolve-se o problema de agência interno à sociedade entre administradores (agentes) e acionistas (principais), no que tange ao sucesso da oferta, conferindo-se aos destinatários da oferta o direito de decidir quanto à sua aceitação final ${ }^{384}$.

O segundo, adotado por meio da regulação norte-americana sobre a transferência de controle da sociedade anônima. Aqui, apresenta-se o que Paul Davies e Klaus Hopt caracterizam como o duplo poder de veto sobre a oferta pública de aquisição realizada ${ }^{385}$. Facilitam-se as hipóteses de management entrenchment', decorrentes do distanciamento entre o interesse dos acionistas daquele dos administradores da sociedade anônima. Restringem-se, assim, as situações de efetiva transferência de controle, na medida em que são elevados os custos de agência respectivos à relação entre administradores (que exercem poder de veto sobre a operação) e acionistas (destinatários finais da oferta).

Evidencia-se, pois, uma segunda perplexidade, em acréscimo à natureza das estratégias de defesa à tomada de controle acionário: o Reino Unido e os Estados Unidos adotam modelos diametralmente opostos para endereçarem ao mesmo problema de agência, explicada pela influência dos investidores institucionais, no mercado britânico e dos adminstradores, na regulação de takeovers nos Estados Unidos ${ }^{386}$. Alocam-se distintamente os direitos à aceitação quanto à oferta, cujas conseqüências afetam diretamente o

\footnotetext{
${ }^{384}$ Ibid. p. 164.

${ }^{385}$ Ibid. p. 164.

${ }^{386}$ Ibid. p. 164.
} 
número de operações de transferência de controle realizadas em cada $\operatorname{mercado}^{387}$.

No entanto, ambos os modelos aproximam-se ao tratarem de um problema de agência que é comum a todos os mercados de capitais: adquirente e administradores ${ }^{388}$ possuem fortes incentivos para omitir ou realçar aspectos negativos e positivos da oferta, a fim de influenciar sua aceitação ou recusa por parte dos acionistas ${ }^{389}$. Constituem, portanto, peças centrais à regulação da oferta pública de aquisição as normas que materializam o dever de full disclosure dos elementos pertinentes à oferta realizada. Assim se discutiu no item 3.3 deste estudo e, conforme argumentam Frank Easterbrook e Daniel Fischel, é somente através da disposição plena de informação sobre a oferta realizada que se possibilita a adequada tomada de decisão por parte daqueles a quem ela seja endereçada ${ }^{390}$.

Dissociam-se as duas principais transações de controle objeto deste estudo. Enquanto a cessão de controle acionário tende a ocorrer quando as ações representativas do capital votante da companhia encontram-se concentradas, de modo a constituir um bloco destacado de ações cuja aquisição atribua ao adquirente o controle ${ }^{391}$, a oferta pública de aquisição tem lugar em contextos de capital disperso. $\mathrm{Na}$ primeira hipótese, o adquirente negocia privadamente os termos da cessão do controle acionário ou

\footnotetext{
387 Conforme destacam Paul Davies e Klaus Hopt, o número de takeover bids realizadas no Reino Unido ao longo da década de 90 é proporcionalmente mais elevado que nos Estados Unidos. Uma das razões apresentadas pelos autores e que justificam a diferença no número de tomadas de controle é a diferença de cada modelo regulamentar no que tange à regra de passividade dos administradores da companhia-alvo no curso da oferta. Ibid. p. 190.

${ }^{388}$ Ressalva-se que, como discutido no item 4.4 deste trabalho, mesmo em um ordenamento que se lhes imponha a regra de passividade, tal como o britânico, os administradores da companhia-alvo podem buscar influenciar os acionistas em sua tomada de decisão.

${ }^{389}$ Ibid. p. 174.

${ }^{390}$ EASTERBROOK, Frank H.; FISCHEL, Daniel R.. Op. cit., p. 96. DAVIES, Paul; HOPT, Klaus. Op. cit., p. 175.

${ }^{391}$ Especificamente, a diferença entre controle e bloco de ações que lhe representa é discutida no item 4.2. do presente estudo.
} 
diretamente com seu titular. Já na segunda, a oferta proposta é formalizada por meio de um instrumento específico e aberta ao mercado. Na alienação de controle operada por meio de cessão, a oferta pública de aquisição da participação dos acionistas que não aqueles integrantes do bloco de controle somente tende a ocorrer caso o adquirente seja legalmente obrigado a fazê-lo. No Brasil, esta exigência encontra-se prevista no artigo 254-A, da Lei $\mathrm{n}^{\circ}$ 6.404/76, cuja configuração é objeto do item 5.3 seguinte deste capítulo.

No exercício de sua competência regulamentar prevista no artigo $8^{\circ}$, inciso I, da Lei $\mathrm{n}^{\mathrm{o}}$ 6.385, de 7 de dezembro de $1976^{392}$, a Comissão de Valores Mobiliários - CVM, baixou a Instrução $\mathrm{n}^{\mathrm{o}}$ 361, de 5 de março de 2002, que, dentre outras matérias, regula as modalidades de oferta pública de aquisição de ações da companhia aberta ("OPA”). São seis as modalidades de OPA previstas nesta Instrução: (i) OPA para cancelamento de registro, de realização obrigatória, condição para o cancelamento do registro da companhia aberta ${ }^{393}$; (ii) OPA por aumento de participação, obrigatória por força do $\S 6^{\circ}$, do artigo $4^{\mathrm{o}}$, da Lei $\mathrm{n}^{\mathrm{o}} 6.404 / 76^{394}$, decorrente do aumento de participação do acionista controlador no capital social de companhia aberta ${ }^{395}$; (iii) OPA por alienação de controle; obrigatória por força do artigo 254-A, realizada como condição de eficácia de negócio jurídico de alienação de controle de companhia aberta ${ }^{396}$; (iv) OPA voluntária; facultativa, aquela em que o ofertante visa à aquisição de

\footnotetext{
392 É a seguinte a redação do dispositivo: "Compete à Comissão de Valores Mobiliários: I regulamentar, com observância da política definida pelo Conselho Monetário Nacional, as matérias expressamente previstas nesta Lei e na lei de sociedades por ações".

${ }^{393}$ Instrução CVM n ${ }^{\circ} 361 / 02$, art. $2^{\circ}$, I.

${ }^{394}$ Prescreve o artigo $4^{\circ}$, em seu parágrafo $6^{\circ}$, da Lei $n^{\circ}$ 6.404/76: "O acionista controlador ou a sociedade controladora que adquirir ações da companhia aberta sob seu controle que elevem sua participação, direta ou indireta, em determinada espécie e classe de ações à porcentagem que, segundo normas gerais expedidas pela Comissão de Valores Mobiliários, impeça a liquidez de mercado das ações remanescentes, será obrigado a fazer oferta pública, por preço determinado nos termos do $\S 4^{\underline{0}}$, para aquisição da totalidade das ações remanescentes no mercado".

${ }^{395}$ Instrução CVM n ${ }^{\circ} 361 / 02$, art. $2^{\circ}$, II.

${ }^{396}$ Ibid. art. $2^{\circ}$, III.
} 
ações de emissão de companhia aberta ${ }^{397}$; OPA para aquisição de controle de companhia aberta, facultativa, a OPA voluntária prevista no caso de aquisição de controle de companhia aberta, conforme dispõe o artigo 257 da Lei $n^{\circ}$ $6.404 / 76^{398-399}$; e (vi) OPA concorrente, facultativa, é a OPA formulada por um terceiro que não o ofertante ou pessoa a ele vinculada e que tenha por objeto ações abrangidas por OPA já apresentada para registro na CVM ou por OPA que, mesmo sem registro, já esteja em curso ${ }^{400}$.

Dentre as modalidades previstas pela Instrução CVM n ${ }^{\circ} 361 / 02$, é objeto de estudo da seção seguinte deste capítulo a OPA em sua modalidade prescrita no inciso III do artigo $2^{\circ}$, da Instrução CVM n ${ }^{\circ} 361 / 02$, ou a OPA por alienação de controle de companhia aberta, obrigatória, conforme prescrevem o caput do artigo 29 da mesma Instrução e o seu $\S 4$ :

"Art. 29. A OPA por alienação de controle de companhia aberta será obrigatória, na forma do artigo 254-A da Lei 6.404/76, sempre que houver alienação, de forma direta ou indireta, do controle de companhia aberta, e terá por objeto todas as ações de emissão da companhia às quais seja atribuído o pleno e permanente direito de voto, por disposição legal ou estatutária. $\S 4^{\circ}$ Para os efeitos desta instrução, entende-se por alienação de controle a operação, ou o conjunto de operações, de alienação de valores mobiliários com direito a voto, ou neles conversíveis, ou de cessão onerosa de direitos de subscrição desses valores mobiliários, realizada pelo acionista controlador ou por pessoas integrantes do grupo de controle, pelas quais um terceiro, ou um conjunto de terceiros representando o mesmo interesse, adquira o poder de controle da companhia, como definido no artigo 116 da Lei 6.404/76 $\$ 5^{\circ}$ Sem prejuízo da definição constante do parágrafo anterior, a CVM poderá impor a realização de OPA por alienação de controle sempre que verificar ter ocorrido a alienação onerosa do controle de companhia aberta".

\footnotetext{
${ }^{397}$ Ibid. art. $2^{\text {o }}$ IV.

398 A oferta pública para aquisição de controle é prevista no artigo 257, da Lei das Sociedades por Ações: "A oferta pública para aquisição de controle de companhia aberta somente poderá ser feita com a participação de instituição financeira que garanta o cumprimento das obrigações assumidas pelo ofertante. $\S 1^{\circ}$ Se a oferta contiver permuta, total ou parcial, dos valores mobiliários, somente poderá ser efetuada após prévio registro na Comissão de Valores Mobiliários. $\S 2^{\circ} \mathrm{A}$ oferta deverá ter por objeto ações com direito a voto em número suficiente para assegurar o controle da companhia e será irrevogável. $\S 3^{\circ}$ Se o ofertante já for titular de ações votantes do capital da companhia, a oferta poderá ter por objeto o número de ações necessário para completar o controle, mas o ofertante deverá fazer prova, perante a Comissão de Valores Mobiliários, das ações de sua propriedade. $\S 4^{\circ}$ A Comissão de Valores Mobiliários poderá expedir normas sobre oferta pública de aquisição de controle".

${ }^{399}$ Instrução CVM n ${ }^{\circ} 361 / 02$, art. $2^{\text {o }}, \mathrm{V}$.

${ }^{400}$ Ibid. art. $2^{\circ}$, VI.
} 
Segue-se, assim, à análise dos precedentes da CVM sobre a configuração da alienação de controle acionário e, mais especificamente, de sua realização, para fins de aplicação do artigo 254-A, da Lei n ${ }^{0}$ 6.404/76.

\subsection{A configuração da alienação do controle acionário no direito brasileiro: tratamento legal e o entendimento da Comissão de Valores Mobiliários - CVM}

Conforme se destacou ao longo desse estudo, o fenômeno do controle e, em especial, de sua transferência, é de extrema relevância para a compreensão da sociedade anônima em suas diversas dimensões. Aqui, destacou-se dois principais aspectos que, sob a regulação vigente no ordenamento brasileiro, são diretamente pertinentes aos termos que regem a transferência de controle: as características da operação e, mais especificamente, da alienação de controle acionário e os direitos que ela enseja. O artigo 254-A, da Lei n ${ }^{\circ} 6.404$, de 15 de dezembro de 1976, inserido pela Lei $\mathrm{n}^{\circ}$ 10.303, de 31 de outubro de 2001, prevê o direito que a doutrina norte-americana denominou tag-along. A análise crítico-conceitual desse 'direito de saída' atribuído aos acionistas da sociedade anônima foi realizada nos itens 3.4 e 4.3 deste estudo, e as características que dão contorno ao tag-along no direito brasileiro são discutidas a seguir. Prevêem o caput e o parágrafo $1^{\circ}$ do artigo 254-A da Lei $n^{\circ} 6.404 / 76$, inserido pela Lei $n^{\circ} 10.303$ de 31 de outubro de 2001:

"Art. 254-A - A alienação, direta ou indireta, do controle de companhia aberta somente poderá ser contratada sob a condição, suspensiva ou resolutiva, de que o adquirente se obrigue a fazer oferta pública de aquisição das ações com direito a voto de propriedade dos demais acionistas da companhia, de modo a lhes assegurar o preço no mínimo igual a $80 \%$ (oitenta por cento) do valor pago por ação com direito a voto, integrante do bloco de controle. $\S 1^{\circ}$ - Entende-se como alienação de controle a transferência, de forma direta ou indireta, de ações integrantes do bloco de controle, de ações vinculadas a acordos de acionistas e de valores mobiliários conversíveis em ações com direito a voto, cessão de direitos de subscrição de ações e de outros títulos ou direitos relativos a valores mobiliários conversíveis em ações que venham a resultar na alienação de controle acionário da sociedade".

O artigo 17, da Lei $n^{\circ} 6.404 / 1976$, condiciona, no inciso III de seu $\S 1^{\circ}$, a emissão pela companhia de ações preferenciais sem direito de voto ou com 
restrição no exercício deste direito à extensão, dentre outros possíveis, do direito inicialmente conferido pelo artigo 254-A somente aos titulares de ações que atribuem direito de voto, também às preferenciais que não o possuam:

“§ $1^{\circ}$ Independentemente do direito de receber ou não o valor de reembolso do capital com prêmio ou sem ele, as ações preferenciais sem direito de voto ou com restrição ao exercício deste direito, somente serão admitidas à negociação no mercado de valores mobiliários se a elas for atribuída pelo menos uma das seguintes preferências ou vantagens: III - direito de serem incluídas na oferta pública de alienação de controle, nas condições previstas no art. 254-A, assegurado o dividendo pelo menos igual ao das ações ordinárias".

Assim, configurada a alienação de controle por seu titular, a lei societária confere aos acionistas titulares de ações ordinárias e aos de preferenciais, que, mesmo sem dispor do direito de voto, sejam titulares de ações que lhes confiram o direito ao tag-along, ou, no caso brasileiro, a faculdade de vendê-las pelo preço mínimo igual a $80 \%$ do valor pago às ações integrantes do bloco de controle.

Por razões metodológicas, concentra-se no estudo da interpretação do colegiado da Comissão de Valores Mobiliários - CVM, nas diversas ocasiões em que a configuração da alienação do controle acionário foi objeto de discussão para fins de aplicação do regime que lhe é correspondente e, em especial, da obrigatoriedade de realização de OPA por força do artigo 254-A da Lei $n^{0}$ 6.404/76. Propõe-se, assim, a divisão do estudo de casos realizado em seguida em três fases distintas ${ }^{401}$.

\footnotetext{
401 A divisão tripartite proposta no presente estudo relaciona-se à compreensão da CVM da obrigatoriedade de se realizar a oferta pública de aquisição das ações que, embora não componham o bloco de controle da sociedade anônima, gozem do direito de serem adquiridas, denominado tagalong. Entende-se que para a análise crítica da tutela legal conferida aos acionistas minoritários e acionistas preferenciais nas hipóteses de alienação de controle, é imprescindível considerar, em acréscimo aos períodos estudados neste ensaio, outros dois momentos: o anterior à revogação do artigo 254 , da Lei $n^{\circ} 6.404 / 76$, em sua redação original, promovida pela promulgação da Lei $n^{\circ} 9.457$, de 5 de maio de 1997, e o subseqüente, compreendido entre a revogação do art. 254, promovida em 1997 e 5 de março de 2002, quando entraram em vigor as alterações referentes à Lei $\mathrm{n}^{\circ} 10.303 / 01$, dentre as quais a inserção do artigo 254-A e da sua redação hoje vigente. Conforme se discute no item 4.3 desse estudo, segundo a redação original da Lei $\mathrm{n}^{\mathrm{o}}$ 6.404/76, era atribuído aos acionistas portadores de ações ordinárias e preferenciais a que fosse atribuído o direito ao tag along o direito de vender as suas ações
} 
A primeira, compreendida até 5 de março de 2002, ou até a entrada em vigor da Lei $n^{0} 10.303$, de 31 de outubro de 2001, que introduziu o artigo 254-A, na Lei $n^{0}$ 6.404/76, regulamentada pela Instrução CVM n ${ }^{\circ}$ 361/02 e publicada na mesma data. A segunda, compreendida entre 5 de março de 2002 e 6 de julho de 2006, ou entre a entrada em vigor da Instrução CVM n ${ }^{\mathrm{o}}$ 361/02 até a sua alteração promovida através da Instrução CVM n ${ }^{\circ} 436$, de 5 de julho de 2006, que alterou algumas de suas disposições. E a terceira, compreendida entre 5 de julho de 2006 e o presente momento, quando passou a vigorar a versão atual da redação da Instrução CVM n ${ }^{0}$ 361/02, consolidada com as alterações trazidas pela Instrução CVM n ${ }^{0}$ 436/06.

No primeiro período, compreendido até 5 de março de 2002, o colegiado da CVM julgou, em 19 de fevereiro de 2002, o Processo CVM n ${ }^{\circ}$ 2001/10329, que tratou de recurso interposto em razão da decisão da Superintendência de Relações com Empresas - SEP, que determinara à Votorantim Celulose e Papel S/A a divulgação de informações requeridas pela Instrução CVM n ${ }^{0}$ 299, de 9 de fevereiro de 1999, que, dentre outras matérias, trata da divulgação de informações decorrente da alienação de controle acionário, em razão da aquisição, pela recorrente, de ações vinculadas a acordo de acionistas firmado pelo bloco controlador da companhia aberta Aracruz Celulose S.A.

No caso, o diretor Marcelo Fernandez Trindade, relator responsável, seguido pela unanimidade dos diretores-membros do colegiado da CVM, entendeu que a configuração da alienação de controle acionário que daria

pelo mesmo valor pago ao titular das ações que compusessem o bloco de controle. Assim, pode-se dizer que, até 1997, no Brasil, adotava-se a tese de William Andrews de que o controle social seria um ativo da companhia e não do controlador que porventura fosse o seu titular. Portanto, sob esta compreensão, seria legítimo repartir o prêmio correspondente ao controle entre os acionistas da companhia, conferindo-se a todos igualdade de condições para alienar suas respectivas participações. Para a discussão crítica das modificações legislativas referentes aos direitos dos acionistas nãocontroladores na alienação de controle: EIZIRIK, Nelson. Reforma da Lei das S.A. $2^{\mathrm{a}}$ Ed.. Rio de Janeiro: Editora Renovar, 1998. p. 24 e ss. 
ensejo à divulgação das informações previstas pela Instrução CVM n ${ }^{0}$ 299/99 não decorreria da alteração da composição do seu grupo de controle, mas sim tão-somente da "transmissão do poder de exercer "a maioria dos votos nas deliberações da assembléia geral e o poder de eleger a maioria dos administradores da companhia (artigo 116, inciso I)", ${ }^{\prime 402}$.

De acordo com a natureza da operação, o diretor Marcelo Fernandez Trindade destacou que:

"Aqui não houve alienação de uma participação majoritária dentro do bloco de controle, como se viu do quadro transcrito no relatório, nem se está diante da aquisição de uma participação que, somada àquela já detida pelo adquirente, o eleve à condição de controlador único. No caso destes autos houve simplesmente a transferência de uma participação que compõe o bloco de controle, mas certamente o Grupo Mondi não alienou nem a VCP adquiriu o controle da sociedade, pois nem o Grupo Mondi detinha isoladamente, nem a VCP adquiriu o poder de, isoladamente, exercer "a maioria dos votos nas deliberações da assembléia geral e o poder de eleger a maioria dos administradores da companhia".

Em contraste à interpretação adotada pela SEP, ao $\S 1^{\circ}$ do artigo 254-A, da Lei $n^{o}$ 6.404/76, introduzido pela Lei $n^{0} 10.303 / 01$ e que, em fevereiro de 2002, ou no momento de julgamento do recurso interposto pela Votorantim Celulose e Papel S.A., ainda se encontrava em vacatio, o diretor Marcelo Fernandez Trindade explica o seu entendimento:

"Tal regra, para ser compreendida, deve ser lida até o seu final, no qual se encontra — de modo um tanto circular, reconheça-se - a afirmação de que, para estar-se diante de aquisição de controle, é preciso que a "transferência, de forma direta ou indireta, de ações integrantes do bloco de controle" resulte "na alienação de controle acionário da sociedade", isto é, na transmissão do poder de exercer "a maioria dos votos nas deliberações da assembléia geral e o poder de eleger a maioria dos administradores da companhia (art. 116, inciso I)".

Deste entendimento pode-se inferir que a alteração do bloco de controle acionário não configura a alienação do controle acionário nos termos do artigo 254-A da Lei das Sociedades por Ações nem, por conseqüência, a aplicação do regime legal nele previsto.

\footnotetext{
${ }^{402}$ Processo CVM n ${ }^{\circ}$ 2001/10329, julgado em 19 de fevereiro de 2002, voto do diretor Marcelo Fernandez Trindade.
} 
No segundo período, quando já se encontravam em vigor o artigo 254-A da Lei $n^{\circ}$ 6.404/76, inserido pela Lei $n^{\circ} 10.303 / 01$, e a Instrução CVM $n^{\circ}$ 361/02, que regulamenta as modalidades de OPA e, em especial, a obrigatória, em virtude da alienação de controle acionário, o colegiado da CVM julgou, em 11 de abril de 2006, o Processo CVM n ${ }^{\circ}$ 2005/4069, de relatoria do diretor Pedro Oliva Marcílio de Sousa. O caso envolveu a alienação de ações da Companhia Brasileira Distribuidora a um grupo de acionistas que, antes da venda das ações da companhia, não integrava o seu capital social. Diante dos fatos em questão, decidiu-se pela obrigatoriedade da realização de oferta pública de aquisição de ações dos demais acionistas da companhia com tal direito, nos termos do artigo 254-A, da Lei ${ }^{\circ}{ }^{\circ} 6.404 / 76$.

O voto do diretor-relator Pedro Oliva Marcílio de Sousa pode ser dividido em três partes principais. Na primeira etapa, o diretor diferencia os requisitos necessários para a aplicação do regime ao controlador previsto nos artigos 116 e 117 da Lei das Sociedades por Ações, daqueles prescritos para a configuração da alienação de controle, nos termos do artigo 254-A, da Lei $\mathrm{n}^{\mathrm{o}}$ 6.404/76. Em seguida, discute-se a restrição às operações de 'alienação' de controle, em lugar de sua 'transferência' para ensejar a obrigatoriedade de oferta pública de aquisição aos demais acionistas com direito ao tag-along e, por último, é abordada a menção feita no dispositivo à transferência de controle acionário "de forma direta ou indireta", para que se configure a alienação de controle e aos efeitos legais.

Sobre a identificação do controlador, Pedro Oliva Marcílio de Sousa distingue os requisitos necessários para a sua identificação como tal e à aplicação do regime previsto nos artigos 116 e 117 da Lei das Sociedades por 
Ações, prescindíveis para se constatar a alienação do controle acionário ${ }^{403}$. Como conclusão preliminar, entende-se, de acordo com a decisão da CVM, que o exercício efetivo do controle acionário por seu titular é dispensável para a constatação da alienação de controle ${ }^{404}$.

\section{O segundo principal trecho que denota o entendimento manifestado por} Pedro Oliva Marcílio de Sousa sobre a configuração da alienação de controle consiste na discussão sobre o conceito estrito de 'alienação de controle', como hipótese de sua transferência, sendo necessária a efetiva transferência dos

403 Os trechos relacionados à identificação do acionista controlador para fins de verificação da incidência do dispositivo foram também utilizados no julgamento do Processo CVM n 2006/6209, que tratou da exigibilidade ou não da realização de OPA por alienação de controle aos acionistas minoritários da Arcelor Brasil S/A. e analisado adiante. Explicou o diretor-relator Pedro Oliva Marcílio de Sousa: "O art. 116, juntamente com o art. 117, tem por objetivo definir os requisitos para que um acionista seja considerado como acionista controlador e as responsabilidades que um tal acionista assume, caso aja como tal. Por isso, como em tantas outras hipóteses de responsabilidade subjetiva previstas no nosso ordenamento jurídico, juntou-se o poder (titularidade de direitos de voto, prevista na alínea "a") e o agir (alínea "b"), para que se possa imputar a responsabilidade a alguém. Já o art. 254-A tem finalidade muito diferente. Ele pretende conferir a possibilidade de uma "compensação" à quebra da estabilidade do quadro acionário, permitindo que os acionistas minoritários alienem suas ações por um preço determinado em lei (que pode ser aumentado pelo estatuto social), quando essa estabilidade for perturbada. O critério eleito pela lei para definir o fim dessa estabilidade do quadro acionário é a "[a] alienação, direta ou indireta, do controle de companhia aberta. (...) $\mathrm{O}$ art. 116, juntamente com o art. 117, tem por objetivo definir os requisitos para que um acionista seja considerado como acionista controlador e as responsabilidades que um tal acionista assume, caso aja como tal. Por isso, como em tantas outras hipóteses de responsabilidade subjetiva previstas no nosso ordenamento jurídico, juntou-se o poder (titularidade de direitos de voto, prevista na alínea "a") e o agir (alínea "b"), para que se possa imputar a responsabilidade a alguém. Já o art. 254-A tem finalidade muito diferente. Ele pretende conferir a possibilidade de uma "compensação" à quebra da estabilidade do quadro acionário, permitindo que os acionistas minoritários alienem suas ações por um preço determinado em lei (que pode ser aumentado pelo estatuto social), quando essa estabilidade for perturbada. O critério eleito pela lei para definir o fim dessa estabilidade do quadro acionário é a "[a] alienação, direta ou indireta, do controle de companhia aberta". Processo CVM n 2005/4069, julgado em 11 de abril de 2006.

${ }_{404}$ Ainda conforme destacou o diretor-relator Pedro Oliva Marcílio: "Essa conclusão é reforçada em razão de o $\S 1^{\circ}$ do art. 254-A procurou definir o que se entende por "alienação de controle" para aplicação do disposto no caput. Nessa definição, não se utilizou de qualquer expressão que indique que, para fins do art. 254-A, o controle está relacionado com o seu exercício. (...) Não há, portanto, referência à necessidade do exercício efetivo do poder, exigindo, tão somente, a propriedade dos valores mobiliários que permitiriam esse exercício. (...) Contra esse argumento, não se pode nem mesmo afirmar que o relevante é a alienação e não a aquisição, pois o art. 254-A menciona expressamente o adquirente do controle. Não sem outro motivo, tem-se como pacífico que a alienação de controle mediante oferta pública para investidores dispersos não gera oferta pública (pois ninguém o adquire). (...) Por todos esses argumentos, parece-me correto não se exigir o preenchimento do requisito previsto no art. 116, "b" (exercício do poder), para que se exija a realização de oferta pública." Ibid. 
valores mobiliários representativos do controle acionário para que se configure a alienação de controle nos termos do artigo 254-A, da Lei n ${ }^{0} 6.404 / 76^{405}$. Dessa forma, entende-se, por exemplo, que a cessão gratuita do controle acionário não daria ensejo ao tag-along por parte de seu titular, sendo necessário o caráter oneroso para a aplicação do regime prescrito no artigo 254-A da Lei societária.

Nelson Eizirik apresenta duas hipóteses que, pelas mesmas razões, não configuram a alienação de controle para fins de aplicação do artigo 254-A, da Lei das Sociedades por Ações. Primeiro, a cessão de crédito por uma instituição financeira credora da sociedade, que sobre a mesma exerce uma influência dominante a outra instituição, característica à modalidade de controle externo. Segundo, a substituição do corpo de administradores da sociedade que, diante de um elevado nível de dispersão do capital acionário da companhia, tem o seu controle exercido pelos próprios administradores, configurando o controle gerencial, classificado no capítulo 2 deste estudo ${ }^{406}$.

Por fim, destaca-se do entendimento manifestado pelo colegiado da CVM no julgamento deste processo, que a verificação da alienação de controle independe da forma com que o controle passe a ser exercido em virtude de sua

\footnotetext{
405 De acordo com trecho do voto do diretor-relator Pedro Oliva Marcílio de Sousa: "Ainda nesse tópico, o $\$ 1^{\circ}$ do art. 254-A, ao ligar a alienação de controle à transferência de valores mobiliários desconsidera, a priori, os efeitos dos acordos de voto para fins do art. 254-A, fixando-se, apenas, na transferência de valores mobiliários (...) Com isso, pode-se dizer que operações em que não ocorre transferência de valores mobiliários, mas apenas de direitos de voto, não há, a priori, oferta pública, nos termos do art. 254-A. Por outro lado, a transferência de valores mobiliários, mesmo mantendo os direitos de voto nas mãos do alienante, em razão de disposição contratual, pode dar causa a ofertas públicas de alienação de controle. O que é importante, para fins do art. 254-A é que os valores mobiliários transferidos façam com que o alienante passe a ter menos do que $50 \%$ das ações com direito a voto e o adquirente, no mínimo, $50 \%$ mais uma ação com direito a voto (no caso de valores mobiliários conversíveis ou que permitam a subscrição ou o exercício de direito de preferência, após o exercício dessa conversão ou da subscrição), mesmo que existam contratos que mantenham direitos políticos nas mãos do alienante (ou de terceiros) que permitam o exercício de fato do poder de controle (situação inversa - transferência de direitos políticos e econômicos para terceiros sem transferência de valores mobiliários - pode dar causa a oferta pública, em virtude da previsão de alienação direta ou indireta)". Ibid.

${ }^{406}$ EIZIRIK, Nelson. Tema de Direito Societário. Rio de Janeiro: Editora Renovar, 2005. P. 235.
} 
transferência, direta ou indiretamente ${ }^{407}$. Configurada a sua efetivação, deve-se estender aos acionistas que possuam o direito que lhes confere o artigo 254-A, da Lei n ${ }^{\circ} 6.404 / 76$, regulamentado pela Instrução CVM n ${ }^{\circ}$ 361/02:

"Na venda direta, a aplicação do art. 254-A seria inquestionável. Não só o Comprador passaria a ter mais de $50 \%$ das ações, como o vendedor deixaria de ter mais de $50 \%$ das ações. Além disso, o Comprador poderia livremente decidir seu voto. A venda direta com celebração de acordo de acionistas não parece levar a conclusão divergente, pois haveria a transferência da titularidade de ações, de modo a que o Comprador passasse a ter mais de $50 \%$ das ações, com o vendedor deixando de ter mais de $50 \%$ das ações. A questão dos direitos de votos seria indiferente para a análise da questão, em razão do que dispõe o $\S 1^{\circ}$ do art. 254-A. O único questionamento seria o fato de que o alienante também seria considerado acionista controlador, em razão do que dispõe o caput do art. 116. Nada obstante, como já me manifestei acima, o artigo 254-A dispensa o conceito de acionista controlador conforme estabelecido no art. 116. Na terceira hipótese, as ações seriam transferidas para uma sociedade holding na qual o seu interesse econômico, juntamente com sua participação direta, indicaria que ele teria passado a deter mais de $50 \%$ das ações e o alienante menos do que $50 \%$ das ações. No que se refere aos direitos de votos, a situação seria a mesma da operação de venda direta com celebração de acordo de acionistas (ou seja, o adquirente impõe-se uma restrição na sua autonomia sem repercussão para fins do art. 254-A). No que se refere aos direitos econômicos também. Não há, portanto, razão para tratar as duas situações diferentemente" ${ }^{, 408}$.

\section{E conclui:}

"A Instrução 361/02 reconhece a possibilidade de a alienação do controle ser realizada através de em um conjunto de operações (art. 29, $\S 4^{\circ}$ ), e, portanto, nada impede que, em determinadas situações, a OPA somente venha a se tornar obrigatória no momento da conclusão desse conjunto de operações. Entretanto, no caso concreto, a operação de alienação do controle deve considerar-se concluída desde logo, tendo em vista (i) a irrelevância econômica da segunda parte da operação - aquisição por preço simbólico de

\footnotetext{
${ }^{407}$ Explica o diretor-relator: "o significado tradicional dessa expressão [alienação direta ou indireta] dá-se alienação de controle mesmo que se interponha uma sociedade holding para a realização da alienação das ações da companhia aberta - que vinha sendo aplicado pela CVM ainda quando o antigo art. 254, que não falava em alienação indireta, e amplamente aceito pela doutrina, não é o único sentido da expressão. Há um outro significado cuja aplicação só pode ser analisada a partir dos fatos do caso concreto. Esse significado inclui, dentre as operações que dão causa à oferta pública, não só a alienação de ações agrupadas em sociedade holding, mas, também, a inclusão de acertos contratuais que impliquem a transferência dos direitos políticos e econômicos do valor mobiliário, sem a transferência da ação (a conferência de usufruto vitalício de voto e dividendos mediante contraprestação em dinheiro ou a celebração de acordo de acionistas, regulando voto e distribuição de dividendos, por exemplo), tenha esse acordo sido celebrado para se evitar a realizar a oferta pública ou mesmo com vistas a um outro fim lícito. Como isso, para a aplicação do art. 254-A, se em uma operação não se verificar a transferência de valores mobiliários que implique alienação de controle, deve-se analisar se essa alienação ocorreu de forma indireta (i.e., mediante acordos que resultem na transferência de poder político e econômico desses valores mobiliários).” Ibid.. ${ }^{408}$ Ibid.
} 
uma ação ordinária da holding - e (ii) ser a conclusão dessa segunda parte da operação uma faculdade atribuída ao Comprador,"409.

Em síntese, pode-se extrair da decisão tomada unanimemente adotada pelo colegiado da CVM nos termos do voto do diretor-relator Pedro Oliva Marcílio de Sousa que: (i) a inexistência de menção na redação do artigo 254A, da Lei das Sociedades por Ações, da expressão 'acionista controlador' refere-se à não-exigência de sua existência, nos termos do artigo 117 da Lei $\mathrm{n}^{\mathrm{o}}$ 6.404/76, para a configuração da alienação de controle; (ii) exige-se para a configuração da alienação do controle, a efetiva transferência onerosa de valores mobiliários correspondentes ao bloco de controle acionário ${ }^{410}$; e (iii) a expressão 'transferência de forma direta ou indireta' de controle é relacionada à sua alienação propriamente dita a um adquirente que o exerça mediante a interposição de uma sociedade holding na estrutura societária, bem como de qualquer outro modo através do qual o adquirente se torne titular de direitos acionários que lhe confiram a titularidade do controle acionário ${ }^{411-412-413}$.

Sobre o conceito de alienação direta ou indireta, é imprescindível a remissão ao parecer publicado por Alfredo Lamy Filho e José Luis Bulhões

\footnotetext{
${ }^{409}$ Ibid.

${ }^{410}$ EIZIRIK. Nelson Tema de Direito Societário. Rio de Janeiro: Editora Renovar, 2005. p. 236.

${ }^{411}$ Ibid. p. 240.

412 Nelson Eizirik discute o preço a ser pago aos acionistas minoritários quando uma sociedade holding, controladora de várias companhias abertas, tem o seu controle alienado. Como critério de avaliação, o autor propõe o seguinte: "A nosso ver, deve ser realizada uma avaliação, por empresa especializada e independente, de todas as companhias envolvidas, utilizando-se um mesmo critério: valor de bolsa, se todas tiverem ações com liquidez; valor de patrimônio líquido; perspectivas de rentabilidade, ou outro considerado mais adequado à situação. Feita tal avaliação, segrega-se o valor que se presume tenha sido pago pelo controle da companhia aberta, procedendo-se então ao cálculo do preço a ser pago aos minoritários". Ibid. p. 241.

413 A expressão 'direitos acionários' deve ser compreendida em seu sentido amplo para a configuração da alienação de controle acionário no ordenamento jurídico brasileiro. Conforme observa Nelson Eizirik: "A alienação do controle pode ainda ocorrer em etapas, uma vez que optou o legislador, nos termos do parágrafo $1^{\circ}$ do art. 254-A, por listar um elenco exemplificativo de operação que podem ensejar a alibenação do controle acionário, que muitas vezes se desenvolvem ao longo do tempo: venda de ações integrantes do bloco de controle; transferência ou subscrição de debêntures conversíveis em ações ou de bônus de subscrição de ações com direito de voto; cessão de direitos de subscrição de ações ou de debêntures conversíveis etc.”. EIZIRIK. Nelson Tema de Direito Societário. Rio de Janeiro: Editora Renovar, 2005. P. 242.
} 
Pedreira, em que criticam o entendimento da CVM sobre a exegese da redação original do artigo 254, da Lei das Sociedades por Ações:

"Os cedentes das quotas de "Alfa" não são, na definição da lei, acionistas controladores do "Banco" e o objeto da cessão não é o conjunto das ações do capital do "Banco" que assegura seu controle, mas quotas do capital de sociedade "Alfa" que o controla", ${ }^{414}$.

O principal fundamento em que se baseiam os autores para delinear os termos de ocorrência da alienação de controle é sua definição segundo o Conselho Monetário Nacional, tendo em vista a sua competência então existente e, segundo a atual redação da Lei $n^{\circ} 6.385$, de 7 de dezembro de 1976, conferida à CVM, e divergente da interpretação desta autarquia sobre a configuração da alienação de controle ${ }^{415}$ :

"A leitura da Resolução $n^{\circ} 404$ revela que o Conselho Monetário Nacional pretendeu [...] definir com precisão o conceito de "alienação de controle" com o fim de evitar que dúvidas ou divergências de interpretação da lei pudessem dificultar ou impedir a livre circulação das ações de controle das companhias abertas, e a letra dos itens II e III da Resolução no 401 não permite dúvida de que o artigo 254 somente se aplica aos negócios jurídicos de venda ou permuta do bloco de ações que assegure o poder de controle direto da companhia aberta, e nenhum outro" ${ }^{\text {, }}$.

Tendo em vista a opinião dos autores, ainda manifestada sob a égide do artigo 254, da Lei $n^{0}$ 6.404/76 em sua redação original, passa-se à observação das decisões manifestadas pela CVM no terceiro período proposto, ou após a entrada em vigor das alterações introduzidas pela Instrução CVM n ${ }^{0}$ 436/06 à Instrução CVM n ${ }^{0}$ 361/02, realizada em 25 de setembro de 2006. Destacam-se cinco casos que consolidaram o entendimento delineado pelo colegiado da CVM nos dois períodos anteriores. No julgamento do Processo CVM n ${ }^{\circ}$ 2006/6209, de relatoria do diretor Wladimir Castelo Branco Castro, que tratou

\footnotetext{
${ }^{414}$ FILHO, Alfredo Lamy Filho; PEDREIRA, José Luiz Bulhões, Op. cit., 1996. p. 611.

415 Alfredo Lamy Filho e José Luiz Bulhões de Pedreira destacam a redação original da Lei $n^{\circ}$ 6.385/76 que conferia ao Conselho Monetário Nacional fixar a orientação da Comissão de Valores Mobiliários no exercício de suas atribuições. Sobre os precedentes históricos da ampliação da competência da Comissão de Valores Mobiliários, Ibid. p. 615.

${ }^{416}$ Ibid. p. 614/615.
} 
da exigibilidade ou não da realização de OPA por alienação de controle aos acionistas minoritários da Arcelor Brasil S/A, em virtude da ocorrência uma oferta pública hostil realizada pela Mittal Steel Company, pessoa jurídica de direito privado sediada na Holanda, de aquisição do capital social da Arcelor, controladora direta da Arcelor Brasil. O colegiado da CVM decidiu unanimemente que a operação de aquisição indireta do controle da Arcelor Brasil S/A deveria ensejar a realização de OPA aos acionistas com direito ao tag-along. Destaca-se que, nesse caso, a obrigatoriedade da OPA por aquisição de controle foi relacionada não à previsão legal ou regulamentar no direito brasileiro, mas sim à expressa convenção estatutária nesse sentido ${ }^{417}$ :

"Para a Recorrente, quando o art. 10 fala em "oferta pública referida no art. $8^{\circ}$ ", refere-se à oferta de alienação de controle prevista no art. 254-A da Lei 6.404/76, que

\footnotetext{
${ }^{417}$ O diretor-relator Wladimir Castelo Branco Castro destacou, em seu voto, as principais disposições estatutárias em que se embasaram os membros do Colegiado da CVM para compreender pela obrigatoriedade da realização de OPA aos acionistas minoritários da Arcelor Brasil S.A.: "A primeira controvérsia diz respeito à Seção I do estatuto social da Arcelor Brasil ("Da Alienação de Controle"), mais especificamente, à interpretação correta do art. 10 do estatuto social. Convém transcrever os dispositivos: "Art. $8^{\circ}$ - A alienação a título oneroso de bloco de ações que assegure a um acionista, a um grupo de acionistas sob controle comum ou vinculados por acordo de voto, o poder de controle da Companhia, direta ou indiretamente, tanto por meio de uma única operação, como por meio de operações sucessivas, deve ser contratada sob a condição, suspensiva ou resolutiva, de que o adquirente do poder de controle obrigue-se a concretizar uma oferta pública de aquisição das ações dos demais acionistas da Companhia, de forma a lhes assegurar tratamento igualitário àquele dado ao alienante. $\S 1^{\circ}$ - A transferência de ações ou de direitos inerentes às ações da Companhia ou de outros títulos ou direitos relativos a valores mobiliários conversíveis em ações, de forma direta ou indireta, entre Pessoas Relacionadas, mesmo que implique na consolidação do poder de controle em apenas um acionista, não constitui alienação do poder de controle, não dando causa, portanto, à obrigação de realizar oferta pública nos termos do caput deste Artigo. Para fins desta Seção, "Pessoa Relacionada" significa o controlador final da Companhia e as pessoas ou entidades, direta ou indiretamente, sob controle comum de tal controlador. $2^{\circ}$ - O prazo, a documentação e o procedimento da oferta mencionada nesta Seção deverão ser aqueles exigidos pela regulamentação da Comissão de Valores Mobiliários aplicável a ofertas públicas por alienação de controle que estiver em vigor na data da referida alienação". Art. $9^{\circ}$ - A oferta pública de aquisição de ações a que se refere o caput do Artigo $8^{\circ}$ também será exigida quando houver cessão onerosa de direitos de subscrição de ações e de outros títulos ou direitos relativos a valores mobiliários conversíveis em ações emitidos pela Companhia, que venha a resultar na alienação de bloco de ações que assegure o poder de controle da Companhia. Art. 10 - A oferta pública de aquisição de ações a que se refere o Artigo $8^{\circ}$ será também exigida caso uma pessoa, que não uma Pessoa Relacionada, adquira o poder de controle da Companhia por meio de aquisição de ações de emissão do acionista controlador final da Companhia. Neste caso, a sociedade objeto da aquisição do poder de controle ficará obrigada a declarar à Bolsa de Valores de São Paulo ("Bovespa") a mudança em seu controle acionário e a sociedade adquirente deste ficará obrigada a declarar à Bovespa o valor atribuído à Companhia nessa alienação". Processo CVM n ${ }^{\circ}$ 2006/6209, julgado em 25 de setembro de 2006.
} 
também vem citada no art. $9^{\circ}$. Trata-se, assim, da oferta resultante de uma aquisição derivada de controle, sendo que o art. 10 teria tido por finalidade apenas deixar claro que tal oferta seria necessária onde quer que o controlador final esteja localizado, isto é, não importando em que nível societário a alienação de controle viesse a ocorrer, mas sem eliminar a necessidade de que tenha havido uma alienação de controle. Já para as áreas técnicas, o art. 10 disciplinaria uma hipótese nova de OPA obrigatória, diversa da prevista no art. 254-A da Lei 6.404/76 que, por sua vez, viria refletida, com modificações, nos artigos $8^{\circ}$ e $9^{\circ}$ do estatuto social. [...] À vista dessa redação [das cláusulas 8, 9 e 10 do Estatuto Social da Arcelor Brasil S.A.], dizer que se trata de alienação de controle, quando ali se lê aquisição quanto mais quando se leva em conta que aquisição é termo de sentido técnico e efeitos práticos relevantes parece-me forçado. Um descuido na redação seria crível se o artigo tivesse sido desenhado para o estatuto social da Arcelor Brasil, e não quase transposto de um regulamento padronizado, por uma companhia que compara seu estatuto ao do Novo Mercado e em um ponto grande importância prática. Para quase todas as companhias abertas brasileiras essa troca de palavras seria trivial (seria necessário que estivesse sob controle difuso, ou fosse controlada por companhia sob controle difuso para haver consequiências) mas não para a Arcelor Brasil quando realizou a assembléia geral que aprovou tal modificação, em 21.12.2005. A única interpretação que me parece fazer sentido é a de que o art. 10 previu para a Arcelor Brasil uma OPA inexistente na atual legislação para o caso de uma aquisição originária de controle de sua controladora final, conferindo aos acionistas minoritários da companhia brasileira o direito de "retirar-se" pelo mesmo preço oferecido aos acionistas de Arcelor. O fato de se falar em "aquisição de ações de emissão do acionista controlador final da Companhia" indicaria que se pensou mesmo na venda em oferta pública, o que faria sentido na estrutura de capital da $\operatorname{Arcelor.}^{, 418}(. .$.$) As hipóteses são próximas às do$ Regulamento de Listagem do Novo Mercado da Bovespa ("Regulamento do Novo Mercado"), o que condiz com as declarações à imprensa dadas pela Arcelor Brasil pouco antes da reforma estatutária que incluiu os dispositivos. $\mathrm{O}$ art. $8^{\circ}$ combina, com ligeiras alterações, as definições de "Alienação de Controle de Companhia" e "Ações de Controle" com a cláusula 8.1. ("Contratação de Alienação de Controle da Companhia"), todos do Regulamento do Novo Mercado, ${ }^{419}$.

Para, em síntese, concluir que:

"O art. 10 do estatuto social da Arcelor Brasil disciplina uma nova hipótese de oferta pública de aquisição obrigatória, diversa das previstas na legislação brasileira, não se aplicando, pelos fundamentos constantes deste voto, os arts. 116 e 254-A da Lei 6.404/76 [...] no art. 10 do estatuto de Arcelor Brasil, acionista controlador final, é a Arcelor e aquisição do poder de controle tem o conceito que lhe é dado pelo art. $5^{\circ}$ da Lei de OPA, de conformidade, também, com a $13^{a}$ Diretiva Européia; e [...] pelo conceito da lei brasileira, teria havido aquisição do poder de controle da Arcelor Brasil, não se podendo examinar previamente, nem podendo considerar-se contratada, e vinculante, para efeitos jurídicos, o compromisso assumido sob regime de melhores esforços ${ }^{\text {"420 }}$.

Em declaração de voto manifestada no mesmo Processo, o diretor Marcelo Fernandez Trindade destacou as opiniões de Luiz Gastão Paes e

\footnotetext{
${ }^{418}$ Ibid.

${ }^{419}$ Ibid.

${ }^{420}$ Ibid.
} 
Barros Leães e de Nelson Eizirik sobre a relação entre a OPA por alienação e a

OPA por aquisição de controle:

"É interessante notar que dois dos ilustres pareceristas que emitiram opiniões juntadas pela recorrente discordam sobre o tema. O Professor Luiz Gastão Paes e Barros Leães entende que alienação e aquisição de controle devem ser interpretados como sinônimos, na lei e no Estatuto. Já o Professor Nelson Eizirik entende que a OPA do art. 254 é devida apenas quando houver alienação de controle por quem o detenha. Esse fato só contribui para revelar que deve prevalecer, como interpretação da lei, aquela expressamente adotada pela Instrução CVM 361/02, que determina que a alienação de controle por quem o detenha é a condição legal de realização da OPA".

\section{E sobre o tema apontou:}

"Trata-se, assim, da mesma OPA — a OPA a ser realizada tendo por objeto as ações dos acionistas minoritários da Arcelor Brasil, por preço equivalente a $100 \%$ daquele pago pelo controle da Arcelor Brasil - , a ser realizada, contudo, por fundamento diverso (ou, mais precisamente, pela ocorrência de evento futuro e incerto diverso daquele previsto na condição legal). No caso da Lei e do art. $8^{\circ}$ do Estatuto, a condição que determina a realização da OPA é a alienação do controle, o que pressupõe, segundo o entendimento da área técnica da CVM e do Relator, com o qual comungo, a existência de um detentor do poder de controle que o aliene. Já no caso do art. 10 do Estatuto, a condição é a aquisição de ações da controladora da Arcelor Brasil (isto é, de Arcelor) que conferissem diretamente ao adquirente o controle da companhia controladora, e indiretamente o da Arcelor Brasil. (...) A única diferença entre a OPA do art. 10 e a OPA do art. $8^{\circ}$ do Estatuto (e da lei) somente pode ser a condição imposta para a realização da OPA, qual seja a aquisição indireta do controle, independentemente da sua alienação. Tal interpretação se confirma, ainda, pelo fato de que, tratando-se a controladora (Arcelor) de companhia aberta com capital disperso, e portanto sem controlador, a hipótese de alienação indireta do controle da Arcelor Brasil pela alienação do controle da Arcelor seria inexequíivel. Somente poderia ocorrer a alienação direta (venda das ações de controle de emissão da Arcelor Brasil detidas pela Arcelor) ou a alienação indireta através da venda de alguma sociedade através do qual a Arcelor detivesse as ações de controle da Arcelor Brasil. Então, essa OPA do art. 10 do Estatuto é uma OPA por fundamento diverso (estatutário), mas é a mesma OPA de que tratam o art. $8^{\circ}$ do Estatuto e, portanto, o art. 254-A da Lei das S.A., daí decorrendo tratar-se de OPA dependente de registro perante a CVM como OPA obrigatória, o que atrai, desde logo, a competência supervisora da CVM para o caso", ${ }^{\natural 21}$.

É importante ressalvar que, em seguida, no julgado do Processo CVM $n^{\text {o }}$ 2007/1996, de relatoria da diretora Maria Helena Santana, realizado em 21 de março de 2007, também relacionado à obrigatoriedade de realização de OPA aos acionistas da Arcelor Brasil S/A, do relatório elaborado, observa-se que, nas orientações fornecidas pela CVM à companhia adquirente para a

${ }^{421}$ Ibid. 
realização de OPA, não se distinguiu as figuras de OPA por alienação de controle e da OPA por aquisição de controle, para fins de orientação da realização da oferta, embora tal ressalva tenha sido feita nos votos dos diretores Wladimir Castelo Branco Castro e Marcelo Fernandez Trindade, manifestados no julgamento do Processo CVM n ${ }^{\circ}$ 2006/6209:

"Em 25/09/2006, o Colegiado da CVM manteve o entendimento das áreas técnicas sobre a necessidade de realização da OPA. O Colegiado considerou, de um lado, que houve alienação indireta do controle da Arcelor Brasil, e, de outro, considerou o disposto no art. 10 do estatuto da própria Arcelor Brasil, dispositivo que garantiria tratamento igualitário aos acionistas minoritários da companhia em caso de aquisição do seu controle indireto. [...] Em 26/10/2006, seguindo a orientação da CVM, a Mittal Steel e o Banco Santander Banespa protocolizaram perante a SRE pedido do registro de OPA por alienação de controle, tendo por objeto todas as ações em circulação da Arcelor Brasil" ${ }^{\text {"422 }}$.

Em 11 de julho de 2007, no julgamento do Processo CVM n ${ }^{\circ}$ 2007/7830, o diretor-relator Eli Loria manteve a decisão da SEP pela nãoobrigatoriedade de realização de OPA por alienação de controle, em virtude da alteração da composição do grupo de controle da Copesul:

"Braskem, Ultrapar e Petrobras destacaram que a Copesul já era controlada por Braskem e IPQ, detendo cada uma $29,46 \%$ do seu capital votante e total, por acordo de acionistas de 25/8/92, e, assim, uma vez que a Braskem já deteria o controle compartilhado da Copesul, não existiria a obrigatoriedade de realização da OPA referida no art. 254-A da Lei $\mathrm{n}^{\circ} 6.404 / 76^{, 423}$.

Diante das características da operação de consolidação de controle em questão, O diretor-relator expressou o seu entendimento de que:

"A venda de participação a uma pessoa já integrante do bloco de controle não implica, em princípio, na obrigatoriedade de realização de oferta pública. E tal foi o entendimento do Colegiado da CVM, em 22/07/03, ainda que esse não fosse o principal ponto do caso, quando da apreciação do Processo CVM n ${ }^{\circ}$ RJ2002/7888, que tratava da aplicabilidade do art. 256 da Lei no 6.404/76 em caso de aquisição de controle compartilhado, no dizer do Diretor Wladimir Castelo Branco Castro: "Ressalvo que, no meu entender, numa operação em que um controlador vende sua participação - total ou parcial - a outro controlador, não haveria, em princípio, para efeitos do art. 256, compra do controle, pois o comprador já ocupava antes da operação a posição jurídica de controlador, adquirindo apenas um reforço de controle." De uma forma geral, ser a participação majoritária ou minoritária no

\footnotetext{
422 Ibid.

${ }^{423}$ Processo CVM n ${ }^{\circ}$ 2007/7830, julgado em 11 de julho de 2007.
} 
bloco de controle original, por si só, não caracteriza, ou deixa de caracterizar, reforço de controle. Devem ser analisados os termos do Acordo de Acionistas e o efetivo exercício do poder de controle" ${ }^{, 24}$.

Acompanhando o voto do relator, o diretor Marcelo Fernandez Trindade sintetizou, à parte, as principais características da alienação de controle acionário que, juntamente observadas, ensejam o direito previsto no artigo 254-A, da Lei $n^{0} 6.404 / 76^{425}$. É importante destacar a menção que o diretor faz à obrigatoriedade de realização da OPA prevista no artigo 254-A da Lei $n^{\circ}$ 6.404/76 no caso de alienação de controle, que, de acordo com a normatização vigente no direito brasileiro, não existe na aquisição do controle acionário.

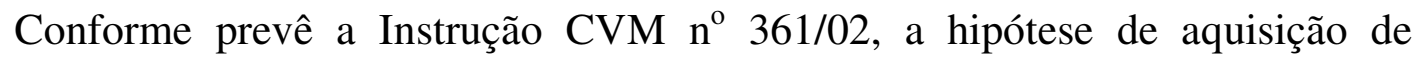
controle refere-se à OPA de realização facultativa por parte do adquirente do controle. Por tais razões, o colegiado da CVM entendeu que a consolidação do controle acionário da Brasken por alteração na composição do bloco de controle da Copesul não deveria implicar na realização de OPA por alienação de controle ${ }^{426}$. É imprescindível a citação do seguinte trecho do voto do diretor, no qual sintetiza o entendimento da CVM sobre as principais características que ensejam a configuração da alienação de controle acionário:

"A Copesul era controlada por Braskem e Ipiranga, unidas por acordo de acionistas, com participação idêntica de 29,46\% do capital votante. Mediante negócio oneroso, Braskem adquiriu da Ipiranga a participação por ela detida indiretamente. (...) O conceito da Instrução antecipa a interpretação da lei pela CVM quanto a alguns pontos relevantes: (i) a alienação pode-se dar por operação isolada ou por um conjunto de operações, dificultando a fraude à lei pelo fracionamento do negócio de aquisição; (ii) a alienação tem que ser realizada por quem já seja, então, acionista controlador ou por pessoa integrante do grupo de controle; e (iii) a

\footnotetext{
${ }^{424}$ Ibid.

${ }^{425}$ Em seu voto, o Diretor Marcelo Fernandez Trindade evidencia as perplexidades relacionadas às hipóteses de consolidação de controle ao se referir ao entendimento manifestado pela SRE: "A SRE entende que quem já é controlador não pode adquirir o controle, e portanto apenas consolida seu controle, o que afastaria a obrigação de realizar OPA por alienação de controle, na forma do art. 254-A da Lei 6.404/76. (...) O argumento da SRE, embora corrente, não me parece bastante para decidir-se a questão. Isto porque o art. 254-A estabelece a obrigação de realizar OPA quando houver alienação do controle, e portanto o argumento de que os integrantes do acordo de acionistas já eram controladores serve para provar que não houve aquisição, mas também para provar que houve alienação, e a lei fala de alienação, como condição para a OPA”. Processo CVM n ${ }^{0}$ 2007/7830, julgado em 11 de julho de 2007.

${ }^{426}$ EIZIRIK. Nelson Tema de Direito Societário. Rio de Janeiro: Editora Renovar, 2005. P. $237 .$.
} 
alienação tem que ser feita a um terceiro. (...) Portanto, parece muito razoável concluir que, ao acrescentar uma referência explícita às "pessoas integrantes do grupo de controle", dentre os alienantes possíveis, a Instrução 361 tenha deixado expresso o entendimento de que a venda de "ações integrantes do bloco de controle", "vinculadas a acordos de acionistas", como previsto no art. 254-A da Lei das S.A., pode redundar na alienação de controle, mesmo quando a venda não seja feita pelo "acionista controlador", mas sim por "pessoas integrantes do grupo de controle". Sendo tal hipótese um caso indisputado de obrigação de realizar a OPA (pois os alienantes transferem em conjunto o controle que detêm em conjunto), pode-se concluir que a referência do $\S 4^{\circ}$ do art. 29 da Instrução 361/02 à alienação "por pessoas integrantes do grupo de controle" não é suficiente para autorizar a conclusão de que a CVM tenha antecipado, com a edição da Instrução, a interpretação de que, no caso de alienação de ações entre integrantes do bloco de controle, com consolidação do controle em um deles, a OPA deve incidir. E isto porque a Instrução pode muito bem ter incluído a referência tendo em mira a situação da venda coletiva pelos integrantes do bloco. (...) "O art. 254-A é explícito ao condicionar a OPA à ocorrência de uma alienação de controle, e, passe o truísmo, somente controladores podem alienar o controle. E o art. 116, I, é igualmente explícito ao dizer que somente se é controlador quando se detém "a maioria dos votos nas deliberações da assembléia geral e o poder de eleger a maioria dos administradores da companhia". (...) O art. 118 da Lei, ao tratar do acordo de acionistas, confirma essa interpretação, porque inclui expressamente (desde a reforma de 2001), como matéria de tal negócio típico, o exercício do poder de controle pelos acionistas unidos pelo acordo. (...) $\mathrm{O}$ principal argumento dos que advogam a tese de que a consolidação do controle importa alienação do controle é o de que se verificam dois elementos suficientes para a ocorrência de tal negócio: (i) os agentes que alienam e que adquirem as ações representam interesses econômicos diferentes, e portanto devem ser tratados como pessoas diferentes; (ii) da alienação decorre uma alteração no controle, pois o antigo integrante que compartilhava o controle passa a controlar isoladamente, e (iii) o preço pago normalmente embute um prêmio de controle. (...) Como visto, pelos arts. 116 e 118 da lei quem controla é o grupo de pessoas vinculadas por acordo de voto. E isso não se relaciona com a responsabilidade por abuso de que trata o art. 117 - que é sempre individual. Relaciona-se com a configuração jurídica do controle. E essa configuração é que é útil no caso, pois a Lei brasileira não estabelece que a aquisição do controle de quem não o detenha determina a realização de OPA - como ocorreria com a aquisição de ações isoladas que, reunidas, assegurassem o controle. Em outras palavras: a lei não exige apenas uma alteração no controle; exige uma alienação por quem o detenha" 427 .

Marcelo Fernandez Trindade evidencia, após compreender pela nãoconfiguração da alienação do controle nos termos legais e, por consequiência, pela inexistência do direito ao tag-along no caso em questão, as perplexidades existentes na exegese do artigo 254-A, da Lei das Sociedades Anônimas:

Concluir pela não obrigatoriedade de OPA em casos de consolidação do controle dentro do bloco não é, certamente, adotar a decisão mais simpática. E certamente este não é o voto que eu mais gostaria de dar. De lege ferenda, me parece que a alienação de participações relevantes, conforme percentual previsto em lei ou no Estatuto, deveria gerar a obrigação de

${ }^{427}$ Ibid. 
estender as mesmas condições aos demais acionistas, através da realização de OPA. Isto contribui para que o valor das ações de uma companhia aberta seja estabelecido pelo mercado de maneira mais adequada, sem prêmios ou descontos economicamente pouco justificáveis, decorrentes de direitos não expressos nos títulos, mas sim inerentes ao exercício do poder. (...) estou de acordo com a conclusão do voto do Diretor Relator, pela inexistência de alienação de controle, que só pode ser alienado por quem o detenha, o que, em casos de acordo de acionistas, significa o grupo de pessoas vinculadas por acordo de voto, como diz o art. 116 da Lei das S.A., e não um membro desse grupo que detenha menos que a maioria das ações com voto, ressalvada a análise do acordo de acionistas, que revele a preponderância do subscritor alienante perante os demais ${ }^{428}$.

Por fim, o diretor Marcelo Fernandez Trindade explica o distinguish ${ }^{429}$ que o fez distanciar-se da rationale, ou da norma extraída de seu voto ${ }^{430}$, no âmbito do Processo CVM RJ 2001/10329, julgado em 19 de fevereiro de 2002, e que poderia induzir à compreensão de que, no caso em questão, seriam observados os requisitos para a alienação de controle nos termos legais ${ }^{431}$. No caso, conforme discutido, entendeu-se que a configuração da alienação de controle acionário que daria ensejo à divulgação das informações previstas pela Instrução CVM n ${ }^{0} 299 / 99$ não decorreria da alteração da composição do seu grupo de controle, mas sim tão-somente da "transmissão do poder de exercer "a maioria dos votos nas deliberações da assembléia geral e o poder de eleger a maioria dos administradores da companhia" (art. 116, inciso I)","432.

\footnotetext{
428 Ibid.

${ }^{429}$ Patrícia Perrone Campos Mello define 'distinguish' como "uma exceção à regra firmada em um julgado anterior”. MELLO, Patrícia Perrone Campos. Operando com Súmulas e Precedentes Vinculantes. In: A Reconstrução Democrática do Direito Público no Brasil. Org. Luis Roberto Barroso. Rio de Janeiro: Editora Renovar, 2007. p. 678/679.

${ }^{430}$ Ibid. p. 672.

${ }^{431}$ Conforme elucida Marcelo Fernandez Trindade em seu voto: "Creio ser meu dever esclarecer que o meu voto em um caso decidido em 2002, antes da entrada em vigor do art. 254-A da Lei 6.404/76, que é frequentemente citado como indicando o reconhecimento de que haveria alienação de controle em casos como o destes autos, não chegou nem perto disso. Naquele voto eu dizia que a questão de fato ali debatida "não desafia as complexas questões que podem surgir quanto ao conceito de alienação de controle detido por grupo de acionistas unidos por acordo", e citava como exemplo dessas complexas questões que podem surgir a "alienação de uma participação majoritária dentro do bloco de controle" e a "aquisição de uma participação que, somada àquela já detida pelo adquirente, o eleve à condição de controlador único" (Processo RJ 2001/10329, decidido em 19.02.02). Pois bem: a questão complexa surgiu, como ali se previa, e era mesmo óbvio que viria ocorrer, e com ela o dever de decidi-la, de que escapei explicitamente naquele voto". Ibid.

${ }^{432}$ Processo CVM n ${ }^{\circ}$ 2001/10329, julgado em 19 de fevereiro de 2002.
} 
Mais recentemente, no julgamento do Processo CVM n ${ }^{\circ}$ 2007/14099, realizado em 29 de janeiro de 2008, o diretor-relator Durval Soledade deferiu o pedido de dispensa realizado pelo The Royal Bank of Scotland Group, de nãorealização de OPA no âmbito do processo de aquisição do controle acionário do ABN Amro Holding, sob o argumento de que a operação em questão enquadrava-se na hipótese legal de alienação de controle e, assim, não ensejava a obrigatoriedade de realização de OPA, prevista no artigo 254-A, da Lei $\mathrm{n}^{0}$ 6.404/76. O principal fundamento apresentado pela adquirente-requerente é que, no caso de aquisição originária de controle de uma companhia aberta, não seria necessária a realização de OPA, segundo a legislação brasileira. Explica Nelson Eizirik:

"Apenas a aquisição derivada de controle acionário, isto é, aquela que ocorre com a transferência onerosa de ações detidas pelo controlador, ou de direitos sobre tais ações, é que dá ensejo à aplicação do disposto no art. 254-A da Lei das S/A" ${ }^{\text {,433 }}$.

É interessante notar que, nos principais trechos do voto em que o diretor destaca, como fundamento ao seu entendimento favorável à requerente da dispensa, a opinião de diversos autores sobre as diferenças entre as hipóteses de alienação e de aquisição originária de controle, respectivamente previstas nos artigos 254-A e 257 da Lei $n^{0}$ 6.404/76, e amplamente discutida no âmbito do Processo CVM n ${ }^{\text {o }}$ 2006/6239 já observado e que envolveu a aquisição do controle indireto da Arcelor Brasil S/A:

"A meu ver, à letra da lei, a obrigatoriedade de realização de OPA disposta no art. 254-A, refere-se tão somente às situações em que há efetiva alienação do controle de uma companhia. Ou seja, é aplicável quando o então acionista ou grupo de acionistas controlador de uma companhia alienam a outro acionista ou terceiro, bloco de ações com direito a voto ou os direitos à sua titularidade que lhes permitiam exercer efetivamente o poder de controle da companhia. (...) Em comunhão com o entendimento de que o art. 254-A somente se aplica aos casos de alienação de controle, trago aqui a opinião de Carlos Augusto Junqueira de Siqueira sobre o assunto: "o art. 254-A incide sobre as operações de transferência do controle desde que alguém o detenha e venha a transferi-lo onerosamente. Essas são as aquisições derivadas". Luiz Leonardo Cantidiano segue a mesma linha, ao afirmar que: "para que venha

${ }^{433}$ EIZIRIK. Nelson Tema de Direito Societário. Rio de Janeiro: Editora Renovar, 2005. P. 238. 
a ser exigida a apresentação da oferta pública de que trata o artigo 254-A da lei, é indispensável que um acionista da companhia, detentor de um bloco de ações ordinárias que asseguram o exercício do poder de controle, aliene as ditas ações a um terceiro, o qual, concluída a operação, substituirá o antigo controlador, passando ele, adquirente, a exercer o poder de comandar os destinos da respectiva companhia.". O autor afirma ainda que restaria configurada a alienação de controle "a transferência, de forma direta ou indireta, (a) de ações integrantes do bloco de controle, (b) de ações vinculadas a acordo de acionistas, (c) de valores mobiliários conversíveis em ações com direito a voto, e (d) a cessão de direitos de subscrição de ações e de outros títulos ou direitos relativos a valores mobiliários conversíveis em ações que venham a resultar na alienação de controle acionário da sociedade". Fábio Konder Comparato, tratando o tema à luz das determinações normativas contidas na Instrução CVM 361/02, assim dispõe: "A Instrução CVM 361, de 5 de março de 2002, disciplinou três tipos de oferta pública de aquisição (OPA) obrigatória: a OPA para cancelamento de registro, a OPA por aumento de participação do acionista controlador, a OPA por alienação de controle (art. $2^{\circ}$ ). Todas pressupõem a existência de controle majoritário." Partindo do entendimento acima elaborado e explicitado, e analisando o caso concreto, entendo que a operação de aquisição do controle do ABN pelo RFS não se amolda à situação do art. 254-A. (...) Sobre o tema, Modesto Carvalhosa, cuja opinião acompanha o entendimento dos autores supracitados, desenvolve quais seriam os elementos caracterizadores de uma alienação de controle: "Dois são os elementos fundamentais para que se caracterize a alienação do controle acionário, para os efeitos do presente art. 254-A: 1) que da operação, em seu conjunto, e de uma só vez ou por etapas, resulte a presença de um novo acionista controlador ou de um grupo de controle (art. 118); 2) e que a transferência do controle, não importa a sua modalidade, apresente um caráter oneroso, ou seja, que em algum momento o antigo controlador ou participante do bloco de controle receba alguma forma de remuneração".Logo, com a oferta pública de aquisição de ações realizada pela RFS, operouse a formação da posição de acionista controlador no ABN, até então inexistente. Assim, a aquisição do controle no caso concreto caracterizou-se como originária, visto que não ocorreu efetivamente a transferência de bloco de controle, tal como acontece na alienação de controle, mas sim o seu surgimento. A doutrina é pacífica quanto à conceituação e a utilização dos conceitos de aquisição de controle derivada e originária, caracterizando-se a última quando da operação resultar a formação de bloco de controle no patrimônio de um acionista ou grupo, até então inexistente na companhia; e está regulada no art. 257 da LSA. Ao contrário, caracteriza-se como aquisição derivada aquela em que um acionista ou um grupo de acionistas controladores transferem o bloco de ações ou os direitos que lhes garantiam o poder de controle a outro acionista ou terceiro, tornando-se estes os novos controladores. A modalidade de aquisição originária, a meu ver, não se enquadra nos requisitos elencados no art. 254-A, mais precisamente a necessidade de ter havido transferência onerosa do controle (alienação), considero afastada a necessidade de realização de OPA no caso concreto. Corroborando esse entendimento, trago a posição de alguns autores. Carlos Augusto Junqueira diz que "a aquisição originária de controle não exige a realização de oferta pública de extensão aos minoritários", caracterizando como originária a aquisição, quando não existir "um bloco de ações de controle, vindo este a ser formado, mediante oferta de compra de ações no mercado, por parte de terceiro (ou acionista), que passará a controlar a companhia" Carvalhosa também segue esse entendimento, conforme se observa abaixo: "Tratando-se de aquisição originária, o entendimento da CVM, na vigência do art. 254 da lei $n^{\circ} 10.303$, de 2001, manifestado na prática de atuação de sua então existente Gerência de Operações Especiais -GEO, era no sentido de que não seria obrigatória a oferta pública, visto que inexistente a alienação do controle acionário". "A redação deste art. 254-A segue tal entendimento, uma vez que: 1) o caput dispõe que a oferta pública aos minoritários visa a assegurar-lhes preço no mínimo igual a $80 \%$ por ação com direito a voto, integrante do bloco 
de controle, ou seja, há de ter existido previamente um bloco de controle; 2) o preço da oferta pública é calculado sobre o valor pago pelas ações integrantes do bloco de controle, ou seja, há de ter sido feito algum pagamento aos integrantes do bloco de controle". Em sua obra, Reforma da Lei das S.A., Cantidiano ensina que: "(...) ainda que haja, por parte de terceiro, estranho ao grupo de controle, a aquisição originária de um bloco de ações que assegure, ao referido terceiro, a partir da citada aquisição, comandar os destinos da companhia, não será obrigatória a apresentação, pelo novo controlador, de oferta pública dirigida aos acionistas minoritários, porque não terá ocorrido, em tal hipótese, alienação de controle que origine a obrigação de formular proposta pública de compra das ações que são detidas pelos demais acionistas da companhia, também titulares de ações ordinárias de sua emissão"'. (...) Nesses termos, voto pela confirmação do entendimento do requerente, no sentido da não exigibilidade da realização de OPA no caso concreto, ${ }^{, 434}$.

Por último, no julgamento do Processo CVM n ${ }^{0}$ 2008/4156, realizado em 17 de junho de 2008, o colegiado, por maioria, reformou o entendimento da SRE manifestado no âmbito do Processo CVM n ${ }^{\circ}$ 2008/53, que versa sobre o registro de oferta pública em decorrência da alienação do controle da Suzano Petroquímica S/A à Petróleo Brasileiro S/A. - Petrobras, e que decidiu pela obrigatoriedade de realização de OPA, nos termos do artigo 254-A da Lei $\mathrm{n}^{\mathrm{o}}$ 6.404/76. O colegiado da CVM deliberou, por maioria, acolher o recurso interposto, por entender que não teria ocorrido alienação de controle, nos termos previstos no $\S 1^{\circ}$ do artigo 254-A, da Lei $n^{\circ}$ 6404/76, nos termos do voto do diretor Marcos Barbosa Pinto.

São os seguintes os principais trechos do voto do diretor-relator Sérgio Eduardo Weguelin Vieira que, para fins didáticos, são transcritos como contraponto ao voto condutor manifestado pelo diretor Marcos Babosa Pinto:

"A questão central deste processo é a presença de elementos suficientes para ensejar a realização de oferta pública de aquisição de ações por alienação de controle. Não se nega que ao fim de todo o processo a Unipar assumirá o controle da SZPQ, em substituição à Petrobras. Nega-se, porém, que isto ocorra por meio de (i) uma transferência de valores mobiliários; e (ii) que esta eventual transferência seja onerosa, dois requisitos sem os quais não haveria que se falar na necessidade de realização de oferta pública nos termos do art. 254-A da Lei 6.404/76. Realmente não há transferência direta de valores mobiliários entre Petrobrás e Unipar. Do ponto de vista estritamente formal, os valores mobiliários que assegurarão a esta última o controle da Dapean (e assim indiretamente da SZPQ) serão alcançados em razão da incorporação da Fasciatus pela Dapean, por mera conseqüência

${ }^{434}$ Processo CVM n ${ }^{\circ}$ 2007/14099, julgado em 29 de janeiro de 2008. 
matemática (i) do valor dos ativos detidos por estas duas sociedades e (ii) do fato de a Unipar ser titular da totalidade do capital da Fasciatus. Porém, o fato é que a Petrobrás inicia a segunda parte da operação como controladora da SZPQ e passa à condição de minoritária, tendo sua participação indireta diminuída de $99,9 \%$ para aproximadamente $40 \%$ do capital votante desta sociedade. Inversamente, a Unipar resulta detentora indireta da maioria do capital votante, antes pertencente à Petrobrás. Uma operação com tal desfecho só poderá ocorrer com o consentimento da Petrobrás, que será recompensada por não mais possuir as ações suficientes ao exercício do poder de controle.Em linha com decisão anterior do Colegiado, considero que o art. 254-A se aplica às hipóteses de transferência indireta de controle, assim considerada a transferência, por meio de acordo, dos direitos políticos e econômicos dos valores mobiliários que asseguram o poder de controle. O consenso entre o acionista que deixa o controle e aquele que o assume - a alternância do controle da SZPQ foi um dos objetivos declarados de todo o processo - configura esta hipótese de transferência indireta, a meu sentir.(...) Em outras palavras, embora não haja transferência direta de valores mobiliários, há um efeito prático equivalente, que justifica a realização da OPA. Este efeito prático se reflete, inclusive e principalmente, na compensação financeira da mudança de controle. Passo agora a analisar esse ponto, e ao fazê-lo tentarei demonstrar que a onerosidade negada pelos requerentes está presente na operação. (..) Aos minoritários de SZPQ, portanto, deve ser dada esta mesma opção feita pela Petrobras. Se não aderirem à Primeira Oferta, deve-se permiti-los converter suas participações em SZPQ em ações da CPS, de modo que, se julgarem conveniente, possam equiparar-se à Petrobras. De outro modo não se estará atendendo a principal finalidade do art. 254-A, que é promover o alinhamento de interesses e o tratamento eqüitativo entre o acionista controlador e os minoritários" ${ }^{\text {"35. }}$.

Como se pode perceber, embora o diretor Sérgio Eduardo Weguelin Vieira tenha se referido em seu voto ao precedente estabelecido no julgamento do Processo $n^{\circ}$ 2005/4069, realizado em 11 de abril de 2006, e que tratou da alienação de ações da Companhia Brasileira Distribuidora ${ }^{436}$, a rationale do referido caso e afirmado no julgamento do Processo CVM n ${ }^{\circ}$ 2007/7830, que tratou da alteração do bloco de controle acionário da Copesul, julgado em 11 de fevereiro de 2007, afasta-se da hipótese envolvendo o controle da Suzano Petroquímica S/A, pois, naqueles casos, a decisão adotada teve como fundamento a imprescindibilidade, para fins de aplicação do regime previsto

\footnotetext{
${ }^{435}$ Processo CVM n ${ }^{\circ} 2008 / 4156$, julgado em 17 de junho de 2008.

${ }^{436}$ Conforme destaca o diretor em seu voto: "Em linha com decisão anterior do Colegiado [Processo $\mathrm{n}^{\circ}$ 2005/4069, julgado em 11 de abril de 2006], considero que o art. 254-A se aplica às hipóteses de transferência indireta de controle, assim considerada a transferência, por meio de acordo, dos direitos políticos e econômicos dos valores mobiliários que asseguram o poder de controle. O consenso entre o acionista que deixa o controle e aquele que o assume - a alternância do controle da SZPQ foi um dos objetivos declarados de todo o processo - configura esta hipótese de transferência indireta, a meu sentir".
} 
no artigo 254-A, da Lei $\mathrm{n}^{\circ}$ 6.404/76, da efetiva transferência de valores mobiliários $^{437}$.

\author{
Com efeito, no voto proferido pelo diretor Marcos Barbosa Pinto e
} seguido pelos demais membros do colegiado, à exceção do diretor Sérgio Eduardo Weguelin Vieira, são discutidos os seguintes principais aspectos relacionados ao entendimento consolidado pela CVM sobre a configuração da alienação de controle, bem como a diferenciação de seu regime legal ao de outras operações estruturais na sociedade anônima. Inicialmente, discorre o diretor em seu voto:

"Ninguém tem dúvidas (...) que a incorporação de uma companhia não equivale a uma alienação de controle. A Lei $\mathrm{n}^{\circ}$ 6.404/76 não deixa margem para discussão a esse respeito, pois trata essas operações por meio de dispositivos distintos e de maneira completamente diversa. Tampouco resta dúvida (...) de que a incorporação não gera a necessidade de oferta púbica para os acionistas das companhias diretamente envolvidas, nem mesmo quando ocorre mudança do acionista controlador de uma das companhias. Não há

\footnotetext{
${ }^{437}$ Confiram-se os seguintes trechos dos votos condutores de ambos os julgamentos: "Para decidir esse recurso, gostaria de me fixar em três pontos do art. 254-A. São eles: (...) (ii) a restrição da definição de "alienação de controle" à transferência de valores mobiliários (...). Ainda nesse tópico, o $§ 1^{\circ}$ do art. 254-A, ao ligar a alienação de controle à transferência de valores mobiliários desconsidera, a priori, os efeitos dos acordos de voto para fins do art. 254-A, fixando-se, apenas, na transferência de valores mobiliários (...) Com isso, pode-se dizer que operações em que não ocorre transferência de valores mobiliários, mas apenas de direitos de voto, não há, a priori, oferta pública, nos termos do art. 254-A. Por outro lado, a transferência de valores mobiliários, mesmo mantendo os direitos de voto nas mãos do alienante, em razão de disposição contratual, pode dar causa a ofertas públicas de alienação de controle. O que é importante, para fins do art. 254-A é que os valores mobiliários transferidos façam com que o alienante passe a ter menos do que $50 \%$ das ações com direito a voto e o adquirente, no mínimo, 50\% mais uma ação com direito a voto (no caso de valores mobiliários conversíveis ou que permitam a subscrição ou o exercício de direito de preferência, após o exercício dessa conversão ou da subscrição), mesmo que existam contratos que mantenham direitos políticos nas mãos do alienante (ou de terceiros) que permitam o exercício de fato do poder de controle (situação inversa - transferência de direitos políticos e econômicos para terceiros sem transferência de valores mobiliários - pode dar causa a oferta pública, em virtude da previsão de alienação direta ou indireta)". Processo CVM $\mathrm{n}^{\circ}$ 2005/4069, julgado em 11 de abril de 2006. No mesmo sentido, os termos do voto do diretor-relator Eli Loria, no julgamento do Processo CVM n ${ }^{\circ}$ 2007/7230, realizado em 11 de fevereiro de 2007: "Claro que a análise de uma operação de alienação de controle é feita caso a caso, assim demonstrado pela redação do $\S 5^{\circ}$ do art. 29 da Instrução CVM n ${ }^{\circ} 361 / 02$ que informa aos entes jurisdicionados que a CVM poderá impor a realização de OPA sempre que verificar ter ocorrido a alienação onerosa do controle de companhia aberta. Cabe verificar, portanto, se ocorreu, a par da alienação de valores mobiliários, direta ou indireta, também a aquisição de um poder sobre as atividades da companhia, a luz do $\S 4^{\circ}$ do art. 254-A. A Lei $6.404 / 76 \mathrm{em}$ seu art. 254-A trata da alienação, direta ou indireta, do controle de companhia aberta, e o faz segundo um objeto de análise bastante lato, porquanto indica as operações com valores mobiliários que importem na transferência do poder de controle da empresa, de um titular a outro".
} 
necessidade de oferta pública porque, na incorporação, todos os acionistas devem, via de regra, receber o mesmo valor pelas suas ações Neste caso, porém, o que se disputa não é a necessidade de oferta pública aos acionistas das sociedades diretamente envolvidas na incorporação - Dapean e Fasciatus - mas sim aos acionistas de uma companhia aberta controlada pela incorporadora - Suzano, que deixará de ser controlada por Petrobras e passará a ser controlada por Unipar.Se essa disputa pudesse ser decidida mediante a simples determinação de quem era acionista controlador da Suzano antes da operação e de quem é acionista controlador depois dela, eu seria obrigado a concordar com a SRE e com o Diretor Sérgio Weguelin. Mas nossos precedentes deixam claro que não é assim que se resolve a questão.Nesse sentido, o colegiado da CVM já deixou claro que a existência de um novo acionista controlador não é suficiente para disparar a obrigação de oferta pública. Para que a oferta seja obrigatória, é preciso que o controle passe das mãos de um controlador para outro. Por isso, não há oferta pública nas aquisições originárias de controle. O colegiado também já deixou claro que o art. 116 da Lei $\mathrm{n}^{\circ}$ 6.404/76 não é um bom parâmetro para determinar se uma operação deve dar ensejo a uma oferta pública, por duas razões. Primeiro, porque o art. 116 define o que é "acionista controlador" e não o que é "controle". Segundo, porque o art. 116 visa a identificar o acionista controlador para uma finalidade diversa, qual seja, responsabilizá-lo por abuso de poder" ${ }^{438}$.

Em seguida, o diretor passa à análise do próprio artigo 254-A, da Lei das Sociedades por Ações, e da definição, em seu parágrafo primeiro, do conceito de 'alienação de controle', remetendo-se historicamente à doutrina e aos fundamentos a se conferir o direito de saída denominado tag-along:

"A redação desse dispositivo já foi muito criticada, inclusive por este colegiado. No entanto, ele é o único parâmetro legal a guiar nossa interpretação, razão pela qual devemos tentar extrair o máximo possível de seu texto, interpretando-o literalmente. Neste caso específico, aliás, a interpretação literal parece ser ainda mais indicada do que em circunstâncias normais. Logo de início, precisamos reconhecer que é muito difícil identificar um propósito claro para o art. 254-A. Na literatura internacional, costuma-se atribuir três possíveis propósitos para a obrigatoriedade da oferta pública por alienação de controle: (i) preservar a igualdade entre os acionistas; (ii) repartir o prêmio de controle; e (iii) conferir direito de saída em caso de mudança estrutural. No Brasil, o primeiro objetivo foi aventado na vigência do revogado art. 254, que falava literalmente em "tratamento igualitário". Mas qualquer que fosse a aderência desse propósito à disciplina legal anterior, ela deixou de existir após a reforma, pois o próprio art. 254-A permite o tratamento desigual: o acionista minoritário tem direito a apenas $80 \%$ do preço pago ao controlador. Além disso, só os ordinaristas têm direito à oferta. Por isso, a visão predominante é de que o art. 254-A visa

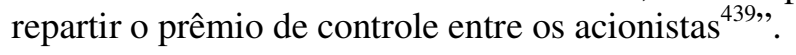

Diante das dificuldades em se interpretar o dispositivo, discutidas ao longo deste estudo, Marcos Barbosa Pinto questiona:

\footnotetext{
438 Ibid

${ }^{439}$ Ibid.
} 
"Mas por que então a oferta deve ser feita por $80 \%$ do valor pago ao controlador? Prêmios de controle pequenos não precisam ser divididos e prêmios maiores só precisam ser divididos acima de um determinado valor? Por que então os preferencialistas são excluídos da oferta? Esses questionamentos já levaram alguns a sustentar, inclusive nesta casa, que o propósito do art. 254-A é dar direito de saída aos acionistas em caso de alteração essencial na estrutura da empresa. Mas por que então a oferta só é exigida quando há efetiva alienação do controle e não em todas as situações em que o controlador da empresa muda, como na aquisição originária? Por que então não se confere o recesso nessa situação, ao invés de $80 \%$ do valor pago ao controlador? ${ }^{440,}$

\section{E como resposta sugere:}

Diante da dificuldade de precisar o propósito do art. 254-A, a interpretação literal parece ser a única saída. E uma saída cujas principais vantagens - segurança e previsibilidade - parecem ser bastante adequadas nesse contexto. Normalmente, aquisições de controle são negócios caros; e a oferta pública é um ônus bastante significativo para o adquirente, um onus que pode alterar completamente o preço pago e, em casos extremos, inviabilizar o negócio. Assim sendo, é muito importante que o critério utilizado para averiguar a necessidade de oferta seja objetivo e previsível, como a interpretação literal costuma proporcionar. Interpretando o texto do $\S 1^{\circ}$ do art. 254-A, não vejo como exigir oferta pública neste caso concreto. Por mais problemas interpretativos que esse dispositivo possa ensejar, um requisito parece estar acima de dúvida: a necessidade de uma "transferência" ou "cessão", seja de ações, seja de valores mobiliários, seja de direitos de subscrição, seja de outros títulos. (...) Neste caso, não houve qualquer transferência: as ações detidas pela Petrobras nunca mudaram de mãos. Antes e depois da incorporação, Petrobras mantém as mesmas ações e em mesmo número. Sua participação societária sofre diluição significativa, o que faz com que ela perca o controle da companhia, mas não há nenhuma transferência. Por conseguinte, não há alienação de controle segundo o critério previsto no $\S 1^{\circ}$ do art. 254-A. Cientes disso, a SRE e o Diretor Sérgio Weguelin procuram dar uma interpretação mais lata ao conceito de "transferência indireta" previsto do $\S 1^{\circ}$ do art. 254-A. Para tanto, buscaram amparo no seguinte trecho do voto do Diretor Pedro Marcilio no Proc. CVM n ${ }^{\circ}$ 2005/4069, decidido em 11 de abril de 2006: Boa parte da objetividade do critério proposto nos parágrafos acima se perde em razão da utilização da expressão "alienação direta e indireta", no caput e no $\S 1^{\circ}$ do art. 254-A. Isso porque, o significado tradicional dessa expressão - dá-se alienação de controle mesmo que se interponha uma sociedade holding para a realização da alienação das ações da companhia aberta - que vinha sendo aplicado pela CVM ainda quando o antigo art. 254, que não falava em alienação indireta, e amplamente aceito pela doutrina, não é o único sentido da expressão. Há um outro significado cuja aplicação só pode ser analisada a partir dos fatos do caso concreto. Esse significado inclui, dentre as operações que dão causa à oferta pública, não só a alienação de ações agrupadas em sociedade holding, mas, também, a inclusão de acertos contratuais que impliquem a transferência dos direitos políticos e econômicos do valor mobiliário, sem a transferência da ação (a conferência de usufruto vitalício de voto e dividendos mediante contraprestação em dinheiro ou a celebração de acordo de acionistas, regulando voto e distribuição de dividendos, por exemplo, tenha esse acordo sido celebrado para se evitar a realizar a oferta pública ou mesmo com vistas a um outro fim lícito). Como isso, para a aplicação do art. 254-A, se em uma operação não se verificar a transferência de valores mobiliários que implique alienação de controle, deve-se analisar se essa alienação ocorreu de forma indireta (i.e., mediante acordos que resultem na

${ }^{440}$ Ibid. 
transferência de poder político e econômico desses valores mobiliários). Tenho dúvidas de que o conceito de "transferência indireta" comporte uma interpretação tão ampla como essa. Seja como for, acredito que os fatos deste caso não se enquadram nem mesmo nessa concepção ampla. Pois mesmo nessa concepção é preciso que haja a transferência de algo, direitos de voto ou o que seja. No caso concreto, como já disse, não há transferência de nada, pois a Petrobrás está mantendo todas as suas ações, com todos os seus direitos" ${ }^{\text {"41 }}$.

Alertando ao final que:

"Prestigiar a interpretação literal e reconhecer que o art. 254-A não se aplica a este caso concreto não significa dizer que todas as operações de incorporação estão isentas da obrigação prevista no art. 254-A. A interpretação literal não afasta o regime da fraude à lei, previsto no art. 166, VI, do Código Civil e aplicável a todos os negócios jurídicos. A operação ora em análise é uma típica incorporação, por meio da qual diversos ativos de um mesmo ramo de atividade são unificados em uma única estrutura societária. Ao contrário do que sugere a SRE, os pagamentos em dinheiro não são contraprestações por alienação de controle. (...) Por estes motivos, entendo que a operação em tela é uma incorporação típica e com finalidade empresarial clara, não sujeita à oferta por alienação de controle prevista no art. 254-A. Note-se, a propósito, que após as operações descritas nos item 1.1 deste voto, Dapean incorporará suas controladas, constituindo uma só empresa operacional. Contudo, é preciso deixar claro desde já que, caso venhamos a nos deparar com incorporações de fachada, utilizando sociedades holding sem ativos operacionais e pagamentos em dinheiro disfarçados, deveremos aplicar a disciplina da fraude à lei, exigindo a realizando da oferta pública, ${ }^{, 42}$.

Por maioria, os diretores membros do colegiado decidiram, pelas razões expostas pelo diretor Marcos Barbosa Pinto, não se estar diante de alienação de controle acionário da Suzano Petroquímica pela Petrobrás S.A. à União de Indústrias Petroquímicas S/A na hipótese em questão.

Em síntese e como conclusão deste item, pode-se inferir as seguintes assertivas sobre o entendimento consolidado do colegiado da CVM sobre a configuração do controle acionário nos termos do artigo 254-A, da Lei $\mathrm{n}^{\mathrm{o}}$ 6.404/76, para fins da oferta pública de aquisição obrigatória, regulada pela Instrução CVM n ${ }^{0}$ 361/02.

Conforme entendimento manifestado pelo diretor-relator Marcelo Fernandez Trindade e seguido pelos demais membros do Colegiado no julgamento do PAS CVM n ${ }^{0}$ 2001/10329 ocorrido em 19 de fevereiro de 2002,

\footnotetext{
${ }^{441}$ Ibid.

${ }^{442}$ Ibid.
} 
antes, portanto, da alteração promovida pela Lei $n^{\circ} 10.303 / 01$ que introduziu o artigo 254-A na Lei $n^{0}$ 6.404/76 e da Instrução CVM n ${ }^{0}$ 361/02, a alteração na composição acionária das sociedades que integram o bloco de controle da companhia não enseja por si a realização da OPA por alienação de controle, salvo quando comportar a aquisição, por um dos membros do grupo, da capacidade em isoladamente, exercer "a maioria dos votos nas deliberações da assembléia geral e o poder de eleger a maioria dos administradores da companhia" ${ }^{443-444}$.

Em segundo lugar, pode-se extrair da decisão manifestada no julgamento do Processo CVM n ${ }^{0}$ 2005/4069, realizado em 11 de abril de 2006, que: (i) a inexistência de menção, na redação do artigo 254-A, da Lei das Sociedades por Ações, à expressão 'acionista controlador' refere-se à nãoexigência de sua existência, nos termos do artigo 117 da Lei ${ }^{\circ}$ 6.404/76, para que se configure a alienação do controle acionário; (ii) exige-se para a configuração da alienação do controle a efetiva transferência onerosa de valores mobiliários correspondentes ao bloco de controle acionário; e (iii) a expressão 'transferência de forma direta ou indireta' de controle relaciona-se à sua alienação propriamente dita a um adquirente tanto mediante a interposição de uma sociedade holding na estrutura societária, como por qualquer outro modo através do qual o adquirente se torne titular de direitos acionários que lhe confiram a titularidade do controle acionário.

Do julgamento realizado em 25 de setembro de 2006, do Processo CVM $\mathrm{n}^{\mathrm{o}}$ 2006/6209, de relatoria do diretor Wladimir Castelo Branco Castro, o colegiado da CVM decidiu se estar diante de obrigatoriedade de OPA por

\footnotetext{
${ }^{443}$ Processo CVM n ${ }^{\circ}$ 2001/10329, julgamento realizado em 19 de fevereiro de 2002.

${ }^{444}$ Conforme explica Nelson Eizirik, para que se configure a alienação do controle acionário, basta a transferência de ações suficientes para que ocorra a transferência do controle acionário, não sendo necessária a transferência de todas as ações que integram o bloco de controle, mas sim do bloco que acarrete na efetiva transferência do controle acionário. EIZIRIK, Nelson. Tema de Direito Societário. Rio de Janeiro: Editora Renovar, 2005. P. 239/240.
} 
aquisição indireta de controle da Arcelor Brasil S/A pela Mittal Steel Company (Lei $\mathrm{n}^{0}$ 6.404/76, artigo 257), não por previsão no ordenamento jurídico brasileiro, mas sim como direito conferido aos acionistas da companhia pelo estatuto social da Arcelor Brasil S/A. Disso se infere a diferenciação de ambas as modalidades de transferência de controle - a alienação de controle e a sua aquisição -à luz do entendimento dos membros do colegiado da CVM e tal como discutido nas duas primeiras etapas deste capítulo 5.

No Processo CVM n ${ }^{0} 2007 / 7830$ de relatoria do diretor Eli Loria, julgado em 11 de julho de 2007, decidiu-se que a OPA prevista no artigo 254A não é obrigatória nos casos de consolidação do controle acionário por parte de integrante do grupo controlador, já que: "De uma forma geral, ser a participação majoritária ou minoritária no bloco de controle original, por si só, não caracteriza, ou deixa de caracterizar, reforço de controle”. Dessa forma: "Devem ser analisados os termos do Acordo de Acionistas e o efetivo exercício do poder de controle" ${ }^{445}$, a fim de se verificar a efetiva configuração da alienação do controle. Conforme complementou o diretor Marcelo Fernandez Trindade em voto separado:

"A Lei brasileira não estabelece que a aquisição do controle de quem não o detenha determina a realização de OPA - como ocorreria com a aquisição de ações isoladas que, reunidas, assegurassem o controle. Em outras palavras: a lei não exige apenas uma alteração no controle; exige uma alienação por quem o detenha" ${ }^{446}$.

Disso depreende-se que a alteração do grupo de controle acionário pode ou não implicar na obrigação de se realizar OPA por alienação de controle, caso o mesmo haja sido alienado por acionista ou grupo de acionistas, independentemente do efetivo exercício anterior do controle acionário.

No julgamento do Processo CVM n ${ }^{\circ}$ 2007/14099, realizado em 29 de janeiro de 2008, o diretor-relator Durval Soledade consolidou o entendimento

\footnotetext{
${ }^{445}$ Processo CVM n ${ }^{\circ}$ 2007/7830, julgado em 11 de julho de 2007.

${ }^{446}$ Ibid.
} 
do colegiado da CVM manifestado no caso em que se decidiu pela obrigatoriedade de realização de OPA por aquisição de controle aos acionistas da Arcelor Brasil S/A no julgamento do Processo CVM n ${ }^{0}$ 2006/6209, no sentido de que não se confundem as figuras de aquisição originária de controle e de alienação de controle, respectivamente previstas nos arts. 257 e 254-A, da Lei no 6.404/76. Segundo o direito positivo, somente enseja a realização de OPA obrigatória a todos os acionistas da companhia com este direito (Lei $\mathrm{n}^{\mathrm{o}} 6.404 / 76$, arts. 254-A e $17 \S 3^{\circ}$, I) a alienação de controle, e não a sua aquisição.

Por fim, no julgamento do Processo CVM n ${ }^{\circ}$ 2008/4156, realizado em 17 de junho de 2008, o colegiado da CVM, por maioria, reafirmou o entendimento de não configurar alienação de controle, segundo a interpretação gramatical do artigo 254-A, da Lei $n^{0}$ 6.404/76, a transferência de controle realizada mediante a incorporação da companhia controladora por outra, sem que estejam presentes: (i) a efetiva transferência de valores mobiliários que acarrete a transferência do controle acionário; e (ii) a transferência do controle acionário de um titular para outro. 


\section{Conclusão}

"Quand après un long effort, la réflexion juridique ne peut aboutir qu'eu se reniant, on peut affirmer que son cheminement n'a été qu'un continuel fourvoiement ${ }^{, 447}$ (Claude Champaud, 1962).

O estudo do poder de controle em suas tantas dimensões justifica-se por sua centralidade à compreensão do fenômeno da sociedade anônima. No entanto, conforme se buscou ilustrar ao longo deste trabalho, a tentativa de se buscar integralmente identificar o exercício de controle no direito societário em suas tantas demonstrações obsta na atipicidade inerente à sua natureza.

Embora elementar para a compreensão da sociedade anônima, o fenômeno do controle em sua acepção anglo-saxônica, ou como sinonímia de poder ou domínio, não se limita ao escopo do direito societário. Conforme se procurou destacar, as relações entre a manifestação de poder na sociedade anônima e em outras áreas do direito denotam a importância de seu estudo nestas dimensões, para que, de acordo com as exigências impostas pela vida em sociedade e diante de sua devida compreensão, se lhe regule o exercício. Na sociedade anônima, a compreensão da manifestação do que se chamou 'poder de controle' levou a duas modificações teóricas principais e, como conseqüência, a alterações em sua regulação. Primeiro, superou-se a identidade entre a assembléia geral e o controlador, ou de se observar, nesse órgão societário, necessariamente, a fonte de expressão da vontade soberana na companhia. E segundo, reconheceu-se, não só a figura do controle interno em suas diversas dimensões na companhia, como também o controle externo à sociedade controlada.

\footnotetext{
${ }^{447}$ CHAMPAUD, C.. Le Pouvoir de Concentration. p. 154/155. Apud. COMPARATO, Fábio Konder; FILHO, Calixto Salomão. Op. cit., p. 47. "Quando, após um longo esforço, o pensamento jurídico não conduzir senão à negação, pode-se afirmar que sua trajetória não passou de um contínuo engano". Tradução livre.
} 
Partindo-se de tais premissas, propôs-se a realização de um estudo crítico do histórico do direito societário contemporâneo e, em especial, dos fundamentos que legitimam a regulação heterônoma da sociedade anônima. Dentre os principais objetos da regulação, deu-se especial destaque à tutela da informação exercida no mercado de valores mobiliários, legítima por quatro razões principais. Primeiro, à luz da analítica delineada por Herbert Hart, entende-se que a faculdade conferida aos sujeitos de direito de contratar a sociedade anônima para, por meio desta, acessar a poupança popular para o desenvolvimento de determinadas atividades econômicas e de delimitar a sua responsabilidade nesse exercício da (possível mediante a prescrição de regras de natureza secundária) deve corresponder à prescrição de obrigações aos sujeitos de direito (possível através da positivação de regras de natureza primária) e dentre as quais se destacam as que visam à realização do princípio do full disclosure no mercado de capitais. Em segundo lugar, essa tutela além de possibilitar a proteção dos diretos participantes da sociedade anônima, permite a realização pela companhia de sua função social. Mais ainda, a regulação do mercado de capitais permite que as forças de oferta e demanda reflitam os reais preços dos valores mobiliários negociados no mercado, justamente por meio da influência que as informações prestadas exercem os termos de sua negociação. Em um quarto aspecto, pode-se, ainda, afirmar que a tutela da informação permite aos agentes econômicos, individualmente considerados, escolher os níveis de informação que desejam ter na realização de investimentos. Por estas quatro razões principais buscou-se justificar a tutela da informação, positivada nos ordenamentos contemporâneos, sob um prisma analítico-funcional. Notou-se, no entanto, que a regulação da sociedade anônima pode impor custos à atividade econômica por meio dela organizada. A partir desta premissa, assinalou-se a teoria estrutural mínima ou o 'ótimo funcional' da regulação da sociedade anônima. 
À vista dos pressupostos que justificam a existência do direito societário em seus fundamentos, propôs-se a leitura das relações decorrentes da sociedade anônima à luz dos problemas entre principais e agentes na companhia e, assim, como meio de se reduzir os custos de agência no exercício da sociedade anônima. A categorização formulada por Henry Hansmann e Reinier Kraakman, que adotam o viés funcional para a análise das relações societárias, possibilitou a classificação dos instrumentos regulatórios e de governança sob a sua melhor luz, ou de modo a permitir a sua adoção no estudo dos elementos e modalidades de transferência do controle acionário a um terceiro. Destacaram-se, assim, as duas principais categorias de transferência de controle segundo a análise funcional proposta: a cessão de controle acionário e a oferta pública à sua aquisição. Antes de se propor o estudo funcional de ambas as modalidades de transferência de controle em espécie, discutiram-se os fundamentos de três de seus principais elementos em sua natureza e regulação: a desejabilidade econômico-social da transferência de controle na sociedade anônima, o prêmio correspondente ao controle acionário e as estratégias de defesa a uma oferta pública de aquisição do controle.

Em síntese, de acordo com a fundamentação proposta ao por Frank Easterbrook e Daniel Fischel para a leitura das relações decorrentes da sociedade anônima, mesmo sob a perspectiva do acionista minoritário, melhor um sistema regulamentar que preze pela otimização do número de transferências de controle, do que restritivo à sua realização. Primeiro, o acionista minoritário é capaz de auferir os melhores resultados sociais advindos do maior valor atribuído como um todo ao mercado, na qualidade de participante da sociedade anônima e de investidor do produto da atividade econômica organizada. E segundo, a transferência de controle permite aos acionistas que, ao invés de permanecerem expostos a uma administração 
menos eficiente, em razão de restrições regulamentares impostas ao 'mercado de transferência de controle' decorrentes de seus custos de transação, os acionistas percebam os potenciais resultados positivos decorrentes do maior valor compreendido pelo adquirente da companhia, em relação ao gerado pela administração presente da companhia-alvo.

As perplexidades relacionadas à regulação da transferência de controle na sociedade anônima em sua positividade foram evidenciadas por sua normatização prevista nos regimes jurídicos britânico e norte-americano, cujas conseqüências econômico-sociais denotam a relevância de se regular a transferência de controle acionário em atenção aos problemas de agência dela decorrentes, ou a fim de se fazê-lo eficientemente. Nestes regimes, conforme observam Paul Davies e Klaus Hopt, a influência dos agentes de mercado, no caso, dos investidores institucionais da City britânica e dos administradores, nos Estados Unidos, explicam a adoção dos modelos regulamentares diametralmente opostos quanto à tomada de decisão na aceitação da oferta pelo controle.

Por último, buscou-se delinear o entendimento consolidado da Comissão de Valores Mobiliários - CVM, sobre a configuração da alienação de controle para fins de aplicação do regime legal previsto no artigo 254-A, da Lei das Sociedades por Ações. Em primeiro lugar, a obrigatoriedade da oferta pública por alienação de controle prescinde do efetivo exercício do controle por parte de seu titular. Segundo, a OPA por alienação de controle pode ocorrer por meio da alienação das ações que compõem o bloco de controle à sociedade holding interposta e tampouco prescinde, necessariamente, da venda do bloco majoritário de ações, decorrendo, ainda, da celebração de acordo de acionistas por meio do qual seja cedido o controle da companhia. Terceiro, por sua natureza distinta, a OPA por alienação de controle, obrigatória, nos termos do artigo 254-A, da Lei $n^{0} 6.404 / 76$ não se confunde com a OPA para 
aquisição, figura que corresponde à aquisição originária de controle, prevista no artigo 257, da Lei $n^{\circ} 6.404 / 76$.

Assim, de acordo com o entendimento consolidado da CVM, excluemse da incidência do artigo 254-A, da Lei $n^{0}$ 6.404/76, ou não configuram alienação de controle as hipóteses de (i) aquisição de controle prevista no artigo 257 da Lei $n^{0}$ 6.404/76; (ii) a cessão gratuita do controle acionário; (iii) a consolidação do controle social por aquisição de participação acionária integrante do bloco de controle; e (iv) a alteração do controle acionário decorrente de operação de incorporação de companhia, sem a transferência de ações correspondentes que ao controle correspondam.

Por tudo o exposto, resta aos estudiosos da sociedade anônima encontrarem os meios que melhor lhes possibilite percorrer a história do controle em sua mutação e efetividade sobretudo, pois, aqui, conforme alerta Hegel em sua concepção ampla sobre o objeto da filosofia do direito, é assim que se permite ao jurista compreender a companhia em sua realidade:

"The science of right is a section of philosophy. Consequently, its task is to develop the Idea - the Idea being the rational factor in any object of study - out of the concept, or, what is the same thing, to look on at the proper immanent development o the thing itself" ${ }^{\prime \prime 48}$.

\footnotetext{
${ }^{448}$ HEGEL. Philosophy of Right. Ap. ADLER, Mortimer; WOLFF, Peter, Philosophy of Law and Jurisprudence. Chicago: William Benton, 1961. p. 210. "A ciência do direito é uma parte da filosofia. Por consequiência, a sua função é desenvolver a Idéia - a Idéia compreendida como um fator racional de qualquer objeto de estudo - extraído de seu conceito ou, similarmente, de observar o desenvolvimento imanente da coisa em si mesma". Tradução livre.
} 


\section{Bibliografia}

ASCARELLI, Tulio, Problemas das Sociedades Anônimas e Direito Comparado. $2^{\text {a }}$ Ed., São Paulo: Editora Saraiva, 1969. p. 255/312.

BARROSO, Luis Roberto, A Reconstrução do Direito Público no Brasil. In: A Reconstrução Democrática do Direito Público no Brasil. Org. Luis Roberto Barroso. Rio de Janeiro: Editora Renovar, 2007. p. 1/39. 790 p.

BAYNE, David Cowan. The Philosophy of Corporate Control - A Treatise on the Law of Fiduciary Duty. Chicago: Loyola University Press, 1986. p. 414.

BERLE, Adolf A. Power. New York: Harcourt, Brace \& World Inc., 1969. 603 p.

Power without property - a new development in American

Political Economy. New York: Harcourt, Brace \& World Inc., 1959. 183 p.

BERLE, Adolf; MEANS, Gardiner. The Modern Corporation and Private Property. New York: Brace \& World Inc., 1969. p. 380. 197/218 e 112/116.

BORBA, José Edwaldo Tavares, Direito societário. $9^{\mathrm{a}}$ Ed., Rio de Janeiro: Editora Renovar, 2004. 581 p.

BORK, Robert H. The tempting of America: the political seduction of the la. New York: The Free Press, 1990. p. 139/141 e 143/160. 160 p

CLARKSON, Kenneth W. et. al. West's Business Law - Text and Cases, $10^{\text {th }}$ Ed.. Mason: Thomson West, 2006. 1400 p.

COMISSO, Ellen. Ethics and Society. San Diego: UCSD Bookstore, 2007. 171 p.

COMPARATO, Fábio Konder; FILHO, Calixto Salomão. O Poder de Controle na Sociedade Anônima. $4^{\mathrm{a}}$ Ed. Rio de Janeiro: Editora Forense, 2005. $597 \mathrm{p}$.

DAVID, René. Os Grandes Sistemas do Direito Contemporâneo. $4^{\mathrm{a}}$ Ed. Rio de Janeiro: Marins Fontes, 2002. 687 p.

DAVIES, Paul. Gower and Davies's Principles of Modern Company Law. $7^{\text {th }}$ Ed. London: Thomson Sweet \& Maxwell, 2003. p. 705/750. 897 p. 
DUBEUX, Júlio Ramalho. A Comissão de Valores Mobiliários e os principais instrumentos regulatórios do mercado de capitais brasileiro. Porto Alegre: Sérgio Antônio Fabris, 2006. 112 p.

EASTERBROOK, Frank H.; FISCHEL, Daniel. The Economic Structure of Corporate Law. London: First Harvard University Press, 1996. p. 370.

EIZIRIK, Nelson et. al. Mercado de capitais - regime jurídico. $2^{\mathrm{a}}$ Ed. Rio de Janeiro: Editora Renovar, 2008. p. 551 a 611.611 p.

EIZIRIK, Nelson. Temas de Direito Societário, Renovar, Rio de Janeiro. 2005. $610 \mathrm{p}$.

$2^{\mathrm{a}}$ Ed., 1998. 466 p.

. Reforma da Lei das S.A. Rio de Janeiro: Editora Renovar,

FILHO, Alfredo Lamy; PEDREIRA, José Luiz Bulhões. A Lei das S.A. vol. I, $3^{a}$ Ed., Rio de Janeiro: Editora Renovar, 1997. 508 p.

. A Lei das S.A. vol. II,

$2^{a}$ Ed., Rio de Janeiro: Editora Renovar, 1996. p. 610/683. 754 p.

GOLDBERG, Daniel. Poder de compra e politica antitruste. São Paulo; Editora Singular, 2006. 308 p.

HAMILTON, Samuel et. al. The Federalist or the New Constitution. Disponível em < http://avalon.law.yale.edu/18th_century/fed78.asp >, Acesso em 9 fev., 2008, às 14:50.

HART, H. L. A. The Concept of Law, with a Postcript edited by Penélope A. Bulloch and Joseph Raz. $2^{\text {nd }}$ Ed. Oxford: Oxford University Press, 1994. 315 p.

HEGEL. Philosophy of Right. Ap. ADLER, Mortimer; WOLFF, Peter, Philosophy of Law and Jurisprudence. Chicago: William Benton, 1961. 251 p.

HESSE, Konhad. A Força Normativa da Constituição. Porto Alegre: Safe, 1991. 34 p.

HOMBERGER, Jacob. Economic Liberty and the Constitution, 2003. Disponível em <http://www.fff.org/freedom/fd0305a.asp>. Acesso em $10 \mathrm{fev}$. 2008 às 22:00. 
JAIN, Sarah S. Lochlann. Injury: Politics of Product Design \& Safety Law in the US, Princeton University Press, New Jersey, 2006. p. 33/59.

JOHNSTON, Alexander. The City Take Over Code, Oxford: Oxford University Press, 1980. p. 1/10. 312 p.

KATZ, Avery Wiener et. al. Foundations of The Economic Approach to Law. New York: Foundation Press, 1998. 442 p.

KRAAKMAN, Reinier et al. The Anatomy of Corporate Law: a comparative and functional approach. Oxford: Oxford University Press, 2004. 231 p.

KRUGMAN, Paul. Economia Internacional: teoria e política, 5 ${ }^{\mathrm{a}}$ Ed. São Paulo: Makron Books, 2004. 797 p.

LEÃES, L.G. Paes de Barros. Mercado de Capitais e Insider Trading. São Paulo: Editora Revista dos Tribunais, 1982. 198 p.

MATTHEW, George C. Blue-Sky Regulation and Public Utility Securities, 1929. Disponível em <http://www.sec.gov/news/speech/1933/0926-272829mathews.pdf>. Acesso em 01.02.2008, 23:55.

MELlO, Patrícia Perrone Campos. Operando com Súmulas e Precedentes Vinculantes In: A Reconstrução Democrática do Direito Público no Brasil. Org. Luis Roberto Barroso. Rio de Janeiro: Editora Renovar, 2007. p. 669/701. $790 \mathrm{p}$.

MICKLETHWAIT, John; WOOLDRIGE, Adrian. The Company - A short history of a revolutionary idea. New York: The Modern Library, New York, 2005. $227 \mathrm{p}$.

MILL, James. An Essay on Government, Encyclopedia Britannica, 1820. Disponível em <http://www.mdx.ac.uk/www/study/xmilgov.htm>. Acesso em 1 fev., 2008, 19:50.

O'BRIEN, David M. Constitutional Law and Politics - struggles for power and governmental accountability, $6^{\text {th }}$ Ed., Vol, I. New York: Norton \& Company, 2005. p. 1/559. 1.068 p.

. Constitutional Law and Politics - Civil Rights and Civil

Liberties, $6^{\text {th }}$ Ed. Vol. II. New York: Norton \& Company, 2005. 1.639 p. 
PARKIN, Michael. Microeconomics, 7th Ed., New York: University of Western Ontario, Pearson Addison Wesley, 2004. 552 p.

PEREIRA, Caio Mário da Silva. Instituições de Direito Civil - Teoria Geral das Obrigações. Vol. II, 20ª Ed., Rio de Janeiro: Editora Forense, 2005. 430 p.

Instituições de Direito Civil - Direitos Reais.

Vol. IV, 20ª Ed., Rio de Janeiro: Editora Forense, 2005. 467 p.

POSNER, Richard A., Economic Analysis of Law, 5th Ed., New York: Court Little Brown and Company, 1998. p. 1/34 e 427/493. 803. p.

REQUIÃO, Rubens. Direito Comercial. Vol. I., $27^{\mathrm{a}}$ Ed., São Paulo: Saraiva, 2005. 542 p.

SILVA, Ricardo Barretto Ferreira; GUIDI, Priscila Guglielme. Poison Pill: mecanismo de defesa contra aquisições hostis ou mecanismo de proteção de dispersão acionária. Acesso em 26 out. 2007. Disponível em <http://www.bovespa.com.br/Investidor/Juridico/060711Nota.asp>

TRINDADE. Marcelo Fernandez, O papel da C.V.M. no mercado de capitais no Brasil. S. Ed.

VELASCO, Julian. The Enduring Illegitimacy of the Poison Pill. University of Notre Dame, The Law School. Acesso em 12 set. 2007. Disponível em $<$ http://papers.ssrn.com/sol3/papers.cfm?abstract_id=825046>

. Structural Bias and the Need for Substantive Review, University of Notre Dame, The Law School. Acesso em 27 out. 2007. Disponível em < http://papers.ssrn.com/sol3/papers.cfm?abstract_id=646882>

-Constituição da República Federativa do Brasil de 5 de outubro de 1988. Disponível em <www>. Acesso em 5 Jun. 2008.

Lei $\mathrm{n}^{\mathrm{o}}$ 10.406, de 10 de janeiro de 2002. Disponível em < http://www.planalto.gov.br/ccivil_03/leis/2002/L10406.htm> Acesso em 1 Fev. 2008.

Lei $\mathrm{n}^{\mathrm{o}}$ 6.404, de 15 de dezembro de 1976. Disponível em < http://www.planalto.gov.br/ccivil_03/LEIS/L6404consol.htm>. Acesso em 1 Fev. 2008. 
Lei $\mathrm{n}^{\mathrm{o}}$ 6.385, de 7 de dezembro de 1976. Disponível em < http://www.planalto.gov.br/ccivil_03/LEIS/L6385.htm>. Acesso em 3 Fev. 2008.

Exposição de Motivos n ${ }^{\circ}$ 196, de 24 de junho de 1976, da Lei n ${ }^{0}$ 6.404/76. Disponível em <http://www.cvm.gov.br/port/atos/leis/6404_Exposicao.asp>. Acesso em 3 Out. 2008.

Instrução CVM n ${ }^{\circ}$ 361, de 5 de março de 2002.

Instrução CVM n ${ }^{\mathrm{o}} 358$ de 3 de janeiro de 2002.

Instrução CVM n ${ }^{0}$ 299, de 9 de fevereiro de 1999.

Instrução CVM n ${ }^{\circ} 10$, de 4 de fevereiro de 1980.

Processo CVM n 2008/4156, realizado em 17 de junho de 2008.

Processo CVM n ${ }^{\circ}$ 2007/14099 realizado em 29 de janeiro de 2008.

Processo CVM n ${ }^{\circ}$ 2007/7830, julgado em 11 de julho de 2007.

Processo CVM n ${ }^{\mathrm{o}}$ 2007/1996, julgado em 21 de março de 2007.

Processo CVM n ${ }^{\circ}$ 2006/6209, julgado em 25 de setembro de 2006.

Processo CVM n ${ }^{\circ}$ 2005/4069, julgado em 11 de abril de 2006.

Processo CVM nº 2001/10329, julgado em 19 de fevereiro de 2002

Portal Eletrônico da Comissão de Valores Mobiliários - CVM $<w w w . c v m . g o v . b r>$

http://www.enronfraudinfocenter.com/information.php>, Acesso em 3 Out. 2008. 